The Poetics of Alchemical Engagement:

\title{
The Allegorical Journey to God in Ripley and Norton after Chaucer
}

\author{
Marcelle Muasher Khoury \\ Charlottesville, VA
}

\begin{abstract}
B.A., American University of Beirut, 1970
M.A., American University of Beirut, 1973

Ph.D., University of Virginia, 2014
\end{abstract}

A Dissertation presented to the Graduate Faculty

of the University of Virginia in Candidacy for the Degree of

Doctor of Philosophy

Department of English

University of Virginia

May 2014 
The Poetics of Alchemical Engagement:

The Allegorical Journey to God in Ripley and Norton After Chaucer

Marcelle Muasher Khoury 
(C) Copyright by

Marcelle Muasher Khoury

All Rights Reserved

May 2014 


\section{Abstract}

Both fifteenth-century alchemical poets, George Ripley and Thomas Norton, perceived themselves to be "Chaucerian" in far deeper ways than has been recognized. They perceived their own work, like Chaucer's, to join author, reader and pilgrim on an essentially hermeneutical journey to Wisdom, and shared with him a deep concern with the human condition of fragmentation and infinite deferral, which they understood Chaucer to relegate to the interpreter's confinement within the natural (sensible and semantic) mode of perception. They likewise perceived themselves to share with him the Boethian belief that this condition can and should be overcome through the hermeneutical pilgrim's "hevy[ng] up the heved," or "heav[ing] up the head," and "entencioun" to ryght "heye thinges" (Boece V, m. 4.35-37), ultimately beyond the entire ontological structure of the Cosmos. The "Philosopher's Stone" was an expression of the resultant entity. Like Chaucer, they consciously sought to harmonize with the Christian faith the natural philosophy that was absorbed into Western Europe through the Late Medieval translation movement. Rather than focusing on their weaknesses and failures, I seek first to understand and appreciate what each of them tried to do. The features they perceive themselves to share with Chaucer can bring attention to structures and meanings in Chaucer that have so far eluded scholars, and can therefore provide new tools for future studies on Chaucer.

The first and introductory chapter presents a general picture of the problem that the "Philosopher's Stone" fundamentally sought to address. I argue that late medieval Christian thinkers, including Chaucer, were deeply concerned with the problem of fragmentation and deferral that temporal infinity presented since the Pre-Socratic natural 
philosophers. They were deeply concerned with what it was that made entitihood, personhood, or meaning possible within a matrix of infinite temporality and absolute relativity. They proposed the Incarnation as the agency through which the contemplative or hermeneutical pilgrim could constitute his being into an indestructible whole. Ripley and Norton belonged to that same quest, and framed it as a quest for the "Philosopher's Stone" which "For of this world . . . is called the sement" (Compound, V.20.1).

The second chapter argues that Ripley textualizes the alchemical operation. He shifts the alchemist's search for the "seeds" of the divine act of creation hidden in the matter of Nature, to a hermeneutical search into the matter of his own text. He hides these seeds in his Compound - which is also his Stone-and teaches his reader to recuperate them through a hermeneutical exercise in which the reader learns to epistemologically "separate" the matter of the text, into its ontological parts and to similarly re-“conjoin" them. Ripley contrasts this epistemological activity of the genuine alchemical philosopher and artist to that of the false "philosophers" who "separate" and re-"conjoin" their matter merely sensibly and semantically, and whom Ripley treats with "Chaucerian" satire. By means of this hermeneutical process, Ripley guides his reader to intellectually enact and internalize the entire ontological structure of the universe, exceed it, pass through death and into a deified and resurrected Philosopher's Stone, microcosm, and embodiment of the Compound itself, jointly 'created' by the author, reader, God and nature.

The third chapter explores some of the similarities and differences between the two late medieval contemplative journeys to Wisdom and union with God, the Christian and the alchemical as they are represented by Bonaventure's Itinerarium Mentis ad Deum 
and Ripley's Compound of Alchemy respectively. I argue that Ripley's alchemical journey exhibits a shift towards the reification of language and the human mind.

In the fourth chapter I demonstrate Thomas Norton's similar "Chaucerian" concern with the human condition of deferral, and similar relegation of this condition to the confinement of the individual's mind within the natural and spatio-temporal mode of perception. I argue that Norton presents his "Ordinall" as a healing unifier which lifts the reader's intentionality towards divine truth, and helps him to turn his mind into a microcosmic opus that aligns all the operations contributing to human being-in both their Ancient and Christian trajectories-into a single trajectory. These operations include the labor of the human artist, the cycles of nature, the life of the English bodypolitic, the sacred History of Creation from beginning to end, and the Church liturgy centered on the Incarnation or the "leap" of the Word as the agency that makes possible one's temporal yet transformative journey to microcosmic existence.

In the fifth chapter I shift attention to the Ancient Greek philosophical roots of alchemy and explore them, especially the Pre-Socratic problematization of infinity and the consequent search for indestructible entitihood, in order to build an understanding of the cyclical trajectory of exitus and reditus from and back to a cosmic "One," which underlies the alchemical operation, and consequently an understanding of the conflicts Norton had to overcome in order to combine the Ancient trajectory with the Christian one. I argue that Norton was aware of and concerned about the radical differences between these two trajectories, the former of "generation" and the latter of "creation." Whether or not he was successful, Norton, I argue, tried to fit the former cosmic trajectory within the latter and wider one which contained the cosmos between a beginning ontologically prior to it and an end similarly beyond it. 


\section{Contents}

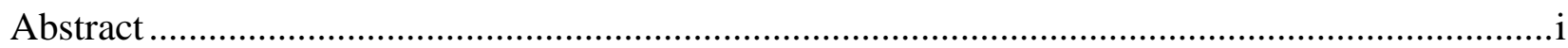

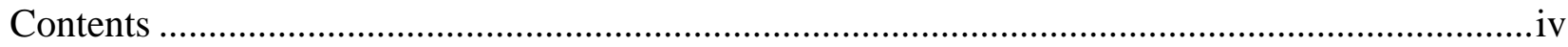

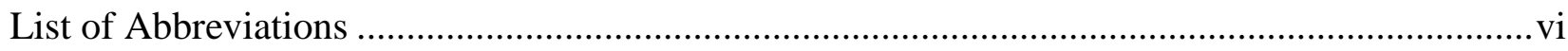

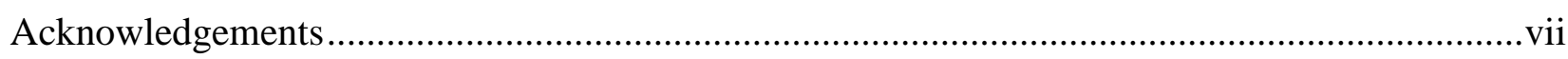

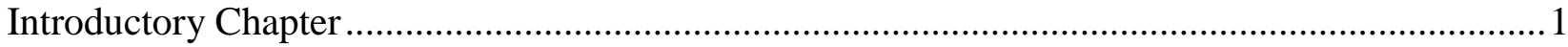

What was Chaucerian About Chaucer? .................................................................................

Chaucerianism and the Philosopher's Stone.................................................................... 1

The Ancient Problem of Infinity and its Medieval Solution................................................. 14

The Problem and its Solution in The Clerk's Tale............................................................. 33

Ripley, Norton and The Canon Yeoman's Tale …………..................................................4 47

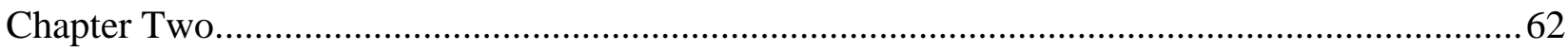

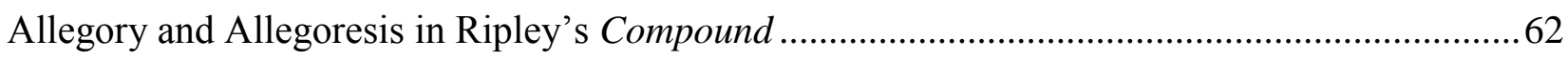

The Compound's Hermeneutical role in the Alchemical Literary Tradition........................67

Philosopher's Stone and reader: Opus and "Childe" ....................................................... 93

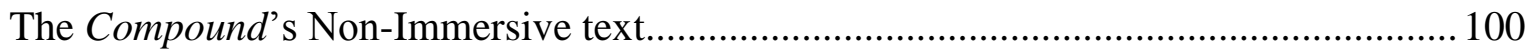

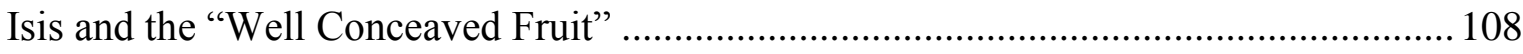

The Four Elements and the Knitting Motif....................................................................... 129

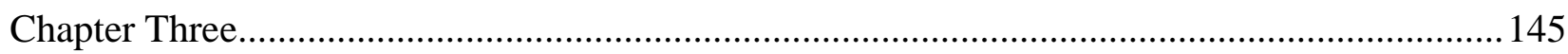

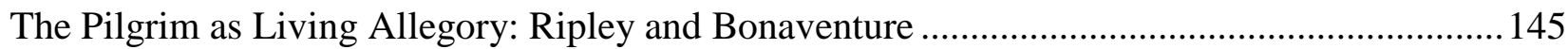

Bonaventure's Itinerarium Mentis in Deum .................................................................. 149

The Compound's Reified Journey ................................................................................ 167

The Stone's liminal experience and 'passage' through death.............................................. 186

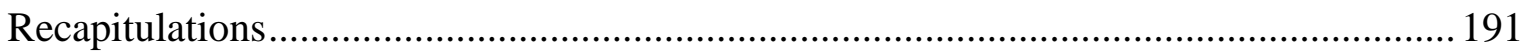

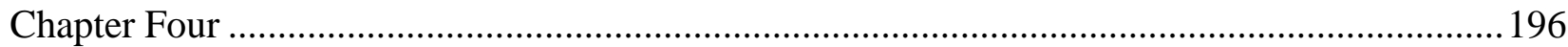


The Beginning, the End, and the "Meen Space" (Part I): Thomas Norton's Ordinal..................... 196

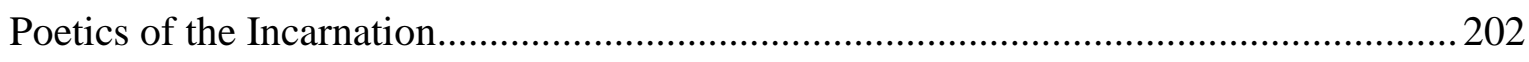

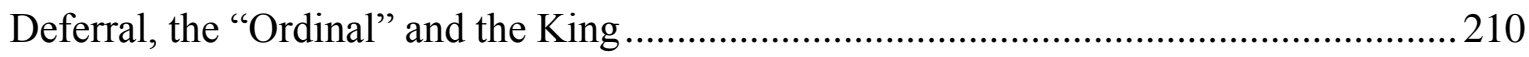

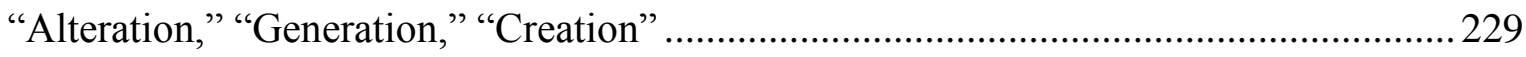

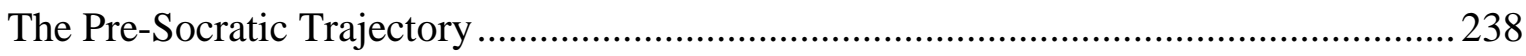

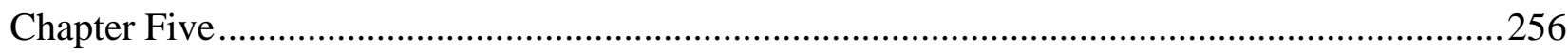

The Beginning, the End, and the "Meen Space" (Part I): "Generation" within Liminal

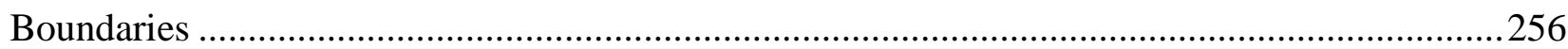

Containing Generation Within Creation …………………………………………. 256

"Lerne this latyne": The Christian Trajectory ……………………………………….....263

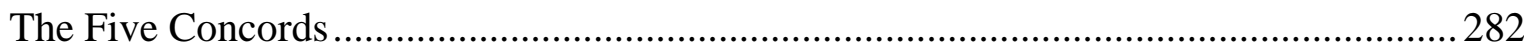

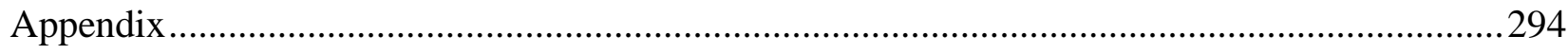

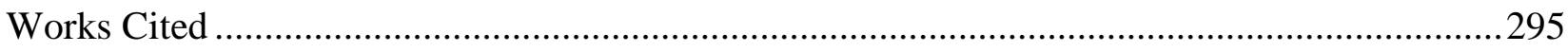




\section{List of Abbreviations}

$\begin{array}{ll}\text { CCEL } & \text { Christian Classics Ethereal Library } \\ \text { Cl.T } & \text { Clerk's Tale } \\ \text { Conf. } & \text { Confessions } \\ \text { CYT } & \text { Canon Yeoman's Tale } \\ \text { KT } & \text { Knight's Tale } \\ \text { Met } & \text { Metaphysics } \\ \text { MLT } & \text { Man of Law's Tale } \\ \text { On Gen. } & \text { On Generation and Corruption } \\ \text { SCG } & \text { Summa Contra Gentiles } \\ \text { ST } & \text { The Summa Theologica }\end{array}$




\section{Acknowledgements}

There are more parties than I can mention, to whom I am indebted for making this dissertation possible. First and foremost, I have deep gratitude for my adviser Professor Bruce Holsinger, whose guidance has helped discipline my argument while at the same time freeing it from needless inhibition. His enthusiastic encouragement and his kind patience with the great passion I have had, and continue to have, towards my topic, have made this dissertation possible, and are gifts that will always remain with me. The freedom he gave me to explore and experiment, while at the same time providing me with unfailing guidance, has been invaluable in furnishing me with a solid foundation for the further projects to which I so look forward. His instantaneous and unfailing response to my manuscript submissions, under all circumstances, such as while he was away from Charlottesville, and even while on the road, leaves me short of words with which I can adequately express my deep gratitude. Any missteps that remain, or flaws of any sort, are entirely my own.

I also owe to Bruce Holsinger many thanks together with Professors A. C. Spearing, Elizabeth Fowler, and Peter Baker for guiding me to George Ripley and Thomas Norton whom I had never heard of before. I initially wanted to write my entire dissertation on Chaucer, and was distraught when I met with rejection. Ripley and Norton seemed at once dull and inscrutable, as though speaking in another planetary language, while seeming too simplistic at the same time. But once I began to understand these two poets - which was after much research and great effort-I found them to be truly exciting, highly knowledgeable, shrewed and complex thinkers, and I ended up feeling very fortunate to have had the benefit of such good advice. Both of these fifteenthcentury alchemical poets drew on a very wide and rich range of mythical, philosophical, 
religious, scientific, alchemical and cultural heritage which covered the most ancient civilizations of the Near East, passing through Ancient Greek and Roman, Alexandrian, Hellenic and Neo-Platonic thought, followed by Gnostiocism, the Early Christian Era, Islamic mysticism and medieval theology. I greatly enjoyed exploring the fascinating connections their work bore to this multiple, complex and rich background, in addition to their deep attachments to Chaucer, not to mention their implied theories of poetic production. I am truly very pleased to have been able to explore these two poets' work for this dissertation.

I owe much gratitude to Professors Gordon Braden, Peter Baker and Kevin Hart, members of my advisory committee, whose considerate and generous help I have been very fortunate to receive. I am greatly thankful to them for putting up with the time constraints with which I was working towards the end of the semester, engaging with my work and critiquing it. I owe much to Gordon Braden's great professional dedication combined with his keen perceptiveness, kindness and magnanimity, which characterized his responses every time I have resorted to him for help and advice. His support and wisdom have been crucial in making this dissertation possible. I also could not have done without Peter Baker's very kind and generous willingness to read my work even when time was ridiculously short. To Kevin Hart I am indebted not only for his kind support and time, but also for his important critique of my dissertation and for his helpful advice for the future.

I am deeply indebted to Professor Hoyt Duggan's support. Not only was he a wonderful, inspiring and unforgettable adviser and Professor during the early eighties, but also continued his support upon my return to Charlottesville in the fall of 2008, even though now retired. He offered crucial insight that helped me clarify the issues I was 
dealing with, particularly in my second chapter. His and Mrs. Gail Duggan's presence and kindness have been an invaluable support and encouragement for me. I am also very grateful to Professor Arthur Kirsch for all that I have learnt from him in the past, and for his magnanimous concern and advice in the spring of 2011, even after my 27 years' absence from Charlottesville. Among my professors in the early eighties I am also grateful to Barbara Nolan who has sadly departed from us, to Del Kolve, Jon Whitman and A. C. Spearing. The enthusiastic spirit of all these professors and what I learned through them has continued to support and inspire me even 26 to 30 years later, while working on this dissertation. To Barbara Nolan I owe first, much of my love for Chaucer, including my very special attachment to the Knight's Tale, and second, a large part of my great passion for all of medieval literature.

My special thanks go to Professor Elizabeth Fowler for her helpful advice and inspiring conversations. Her kindness was a soft light in the darkness of my estrangement during the early period of my return to a largely new and transformed English Department in Charlottesville. A warm light and great comfort in the darkness of my estrangement was also Professor Susan Fraiman, who as DGS facilitated my return and welcomed me back into the department. I also thank Professor A. C. Spearing who very kindly helped me with the application process and facilitated my return to Charlottesville. I thank Professor Anna Brickhouse for her kind support and advice every time I sought it. I also owe special thanks to Professor and Chairman Cynthia Wall. Her kind help was indispensable to my ability to launch the project of this dissertation. I am also indebted to the wise, generous and helpful guidance I received from Professors Daniel Kinney and Paul Cantor. 
I continue to be deeply indebted to Professors Hugh Harcourt and the late George Khairallah who taught me and gave me strong foundations at the American University of Beirut, and whose dedication and brilliance continue to inspire me, as well as to the middle- and high-school teacher from Scotland, loved, admired and respected by all, Miss Mary Harrison, and other teachers of the CMS (Now "The Ahliyyah School for Gorls), who instilled the love of literature in me.

I am grateful to many friends and colleagues in the doctoral program, who have had an inspiring and positive influence on my dissertation. It is impossible to enumerate them all, but I mention among them Christine Schott, Daniel Garner, Ryan McDermott, Gabriel Haley, Ileana Baird, Daniel Heins, Britta Rowe, Rebecca Perederin, and, during my earlier years in Charlottesville, Julie Bates, Michelle Totah, Monica Weis, Carol Callaghan and several other friends. I also dearly thank my friend Dale Gavlak for her unwavering support and encouragement. To my friend Beckwith Miller I owe very special thanks. His invaluable support through times of difficulty or self-doubt, as through times of great enthusiasm, has helped me stay balanced and positively oriented throughout my work on this dissertation.

I thank President and former Prime-minister Adnan Badran, Professor and Chairman Nihal Ameira, and all my friends and colleagues at the University of Petra in Amman, Jordan, for the confidence they have placed in me, and the encouragement they have given me to return to UVA for my doctorate, including Drs. Nouha Homad, Fadia Abdul Hadi, Ola Dabbagh and Janette Mufti.

I know that I will continue to remember and be thankful to many more whom I have not mentioned here including professors, colleagues, students and friends. 
I am deeply grateful to my children Andrew and Angela for sharing with me the pressures of my work, and for understanding and putting up with my passion for it. Their congratulations on my completion of this dissertation have meant a great deal to me. They are an unfathomable inspiration in my life and their presence and support deeply encourage me to continue, and inspire me to do more. I am deeply indebted to my late husband Mike for his generous, highly active, enterprising and enthusiastic spirit which I hope has rubbed off on me a little. I thank my sisters and Brothers, Majida Mouasher Van der Meulen, Maha Phillips, and Mansour, Hana and Amer Mouasher (or Muasher), whose love, deep bonding and commitment have given me the strength I needed to work hard and overcome any difficulties I faced. Finally, in awe and with a great sense of wonder, I offer my deepest and inexpressible gratitude to my departed parents, whose selfless love and unspeakably generous and even sacrificial giving of themselves I continue to discover and understand more profoundly each day. It is to them that I dedicate this work. 
To my departed parents,

Shawqi and Yvonne Mouasher,

who continue to give through the great love they have left behind 


\section{Introductory Chapter}

\section{What was Chaucerian About Chaucer?}

20. For of this world our stone is called the sement Which moved by craft as nature doth require, In his encrease shall be full opulent, And multiply his kinde after thine owne desire, Therefore if God vouchsafe thee to inspire, To know the truth, and fansies to eschew Like unto thee in riches shall be but few.

21. But many men be moov'd to worke after their fantasie, ... (The Compound of Alchemy, V, 20.1-21.1) $\mathbf{1}$

\section{Chaucerianism and the Philosopher's Stone}

The late medieval alchemist's quest for the hidden and divine keys to the “philosopher's stone" was most fundamentally a quest for what it was that constituted a dependable building-block of substantial being, made that building block possible, and enabled it to resist natural deconstruction: "For of this world our stone is called the sement." The mind's natural faculties were immersed in a matrix of infinite time and space. Infinity was by definition absolute. Within its matrix things were, just as absolutely, conditioned by relativity. They were infinitely divisible, and their idenitity and goals infinitely deferred. The problem of infinity underlay the medieval disdain for the world. Basically, that disdain was not aimed at the physical or even sensible world per se. The body was sacred, and functioned as a sacrificial two-way boundary between the natural world and the divine, time and eternity. Caroline Walker Bynum has

\footnotetext{
${ }^{1}$ Satnton Linden, ed., George Ripley's Compound of Alchymy (1591) (Vermont: Ashgate Publishing Co. 2001). All direct quotes form Ripley's verse in the Compound come from this edition, and will henceforth be cited inline.
} 
demonstrated the importance of the physical body ${ }^{2}$ to the medieval Christian mind, and Professor Bruce Holsinger has demonstrated its fundamental agency in the production of sacred meaning, in his Music, Body, and Desire in Medieval Culture. ${ }^{3}$ Rather, it was essentially a disdain for allowing one's perception to be limited to the sensible world. Even the sensible mode of perception in itself was not the object of disdain. That object was people's limitation to this mode. Time, left to itself, is shapeless, and nothing that is conditioned by it can collect itself into form. Through the lenses provided by George Ripley’s (1415-1490) and Thomas Norton's (1433-1513) “Chaucerianism,” the quest for entitihood - and, as such, personhood and "microcosm" — within the matrix of time is a major theme and driving poetic motive in Chaucer's Canterbury Tales.

This study of the two fifteenth-century "Chaucerian poets," George Ripley and Thomas Norton, both "alchemical" poets, reveals them to engage Chaucer in far deeper and more comprehensive ways than has as yet ever been acknowledged. This study also aims beyond itself, at the development of new tools derived from the medieval context itself, through which to further understand Chaucer, and glean further insight into the ways he understood the significance of his own work. In the Canterbury Tales Chaucer offers his readers a collection of tales that align all aspects of historical and ontological, secular and sacred, natural and spiritual being together. His tales range in immediate subject-matter from saintly and sacred subject matter, as the Second Nun's Tale of St. Cecilia, to the low and bawdy, as the Miller's Tale. He also places his tales in a variety of geographical and historical locations - contemporary English, Old English (as in the

\footnotetext{
${ }^{2}$ Caroline Walker Bynum, The Resurrection of the Body in Western Christianity, 200-1336 (New York: Columbia University Press, 1995), Jesus as Mother: Studies in the Spirituality of the High Middle Ages (Berkley: University of California press, 1982) and Fragmentation and Redemption: Essays on Gender and the Human Body in Medieval Religion (NY: Zone Books, 1991).

${ }^{3}$ Bruce W. Holsinger, Music, Body, and Desire in Medieval Culture: Hildegard of Bingen to Chaucer (Stanford: Stanford University Press, 2001).
} 
Man of Law's Tale of Constance), French (Brittany), Italian, Mongol, Ancient Greek and Empirical Roman loci. If we were to look at Chaucer retrospectively through the eyes of those two of his admirers and imitators, George Ripley and Thomas Norton, we would have no doubt that Chaucer's project, in the Canterbury Tales was to build a perfect and all-inclusive microcosm: a Philosopher's Stone.

Most remarkably, Chaucer inscribes the most sacred and solemn truths, as well as the highest disciplines and forms of human knowledge, into the concrete and tangible language spoken by the lewd layman. Into this English language which had not yet been granted even the dignity of inclusion in the educational system, Chaucer inscribes the highest reaching scientific, philosophical and theological knowledge, and the deepest concerns of a Western Europe that had recently widened its horizon to include a multiplicity of Mediterranean and Near Eastern cultures and their bodies of knowledge, mythology, lore and even sacred or quasi-sacred texts. It is also true that through such a concrete and living English language Chaucer served that knowledge and those deepest concerns well, by anchoring them in the lives and intentionalities of actual and living human beings: his readers. The English vernacular served Chaucer's project of concretizing the abstract and spiritualizing the natural and concrete. Ripley and Norton would have also seen Chaucer's vernacularization of knowledge and poetry—which they imitated as well — as a feat and an art that would purify the language from its grossness, and sublime it, and that would congeal the abstract knowledge into concrete truth, just as the alchemist does in the Compound's eighth gate of "Sublimation." Sublimation "make[s] the bodie spirituall," and "the spirite . . corporall bee" (VIII, 7.2-3). They would also have seen this fusion of the low and the high, the concrete and the spiritual as one made possible by the Incarnation, and based on it. Norton described his Stone in 
Eucharistic terms as a "transubstanciacion" (V, 2519-20), and Ripley described this union as "consubstantiall." The alchemist 'sublimes' so "that the spirite may corporall bee, / And become fixt with it , and consubstantiall" (VIII, 7.3-4). They would also have perceived Chaucer to have accomplished this feat of uniting the spiritual to the concrete, by transforming the written text into a hermeneutical journey and basing its meaning not on its slippery semantic referentiality, but on the reader's hermeneutical quest, and on his temporal act of interpretation as his mind engaged in seeking the truth. It is not the semantic meaning that collects the knowledge he obtains into unified truth, but the reader's intentional referent and the 'operation of knowledge' through which he pursues this referent. This is not to say that semantics were unimportant in the Chaucerian architecture Ripley and Norton perceived. The semantic slipperiness of the words played an important role in the dynamic structure through which they produced meaning. They in fact used it to hide their secret and divine kernel of truth from the "lewed" readers who were unaware of any other mode of meaning than the semantic. Their false "philosophres" tried to discover the secret knowledge hidden in the text by merely substituting one semantic referent for another, such as, for example, the metal "mercury" for the word "moon." Thus as argued in the following chapter, Ripley persistently hints to the reader that he must "separate" the textual matter of the Stone epistemologically and ontologically rather than semantically. When Norton quotes Chaucer's “ignotum per ignocius" passage from the concluding part of the Canon Yeoman's Tale (II. 1457), ${ }^{\mathbf{4}}$ he does so with the understanding that the deferral in meaning is due to the ignorant and uninitiated readers', or "philosophers," search for meaning among the reified semantics

\footnotetext{
${ }^{4}$ All Chaucer citations are from Larry Dean Benson and Fred Norris Robinson, eds., The Riverside Chaucer (Oxford: Oxford Univ. Press, 2008).
} 
of the sensible mode of perception, rather than in the act of knowledge itself, its architecture, and what it is that made that act possible.

Chaucer's anchoring the textual body of knowledge in the act of knowledge, and in the knower's intentionality, locates the meaning in the act rather than in the semantic slipperiness of the words. Very importantly, it transforms the semantic slipperiness of the words into rich vehicles of irony that reveal the gap between the seeker's shortsighted materialistic purposes and reified goals, and the Boethian satisfaction and plenitude which every human seeker, whether "philosopher," "artist" or reader, ultimately seeks. It establishes an ironical relationship between the seeker's momentary purpose and that final intentionality to which all human desire converges, the desire for the divine state of happiness, security, satisfaction and fulfillment which, 'Boece' argues, rests in God. Chaucer's vernacularization of knowledge does far more than merely raise the status and cultural wealth of the English language. It does even far more than raise with it the cultural wealth of every speaker of this language regardless how 'lewed'. It acts on the body of knowledge itself, and gives it the advantage of the living truth and experience that the English Language can offer. It anchors the textual matter of this knowledge in the individual's intentional referentiality, and reveals every (inherently) rhetorical-and-hermeneutic act of intentional reference to be most fundamentally a spiritually and morally valent act of seeking- or alternatively, act of the foolish betrayal of one's ultimate goal through the seeking of false goals. It reveals the moral and spiritual responsibility underlying every act of linguistic production, regardless of whether it were speech, writing, or interpretation.

Authors since Late Antiquity have expounded or represented the journey of knowledge, and medieval authors have categorized and organized the body of knowledge 
into didascalic phases of a single journey. But Chaucer transforms this journey in ways similar to the radical reshaping that Dante has given it in the Italian vernacular. He radically grounds this journey in the reader's concrete moment of reading, and gives him the responsibility of its interpretation, and as such, its enactment. By anchoring the body of knowledge in the living moment, and embodying the act of knowledge in the reader, Chaucer pulls the reader into complicity with its rhetorical production and charges him with the recuperation of its meaning. Chaucer charges the reader with the moral and spiritual responsibility for the hermeneutical cycle. To contemporary readers and scholarly interpreters, he sends the message that their act of interpretation is morally and spiritually valent. The quality of the text that results from the interpreter's hermeneutical journey is deeply influenced by the nature of the referent of that interpreter's intentionality.

Chaucer is deeply Boethian in the way he conceives of the journey of knowledge. Through this journey the individual knower "gadreth togidre all thingis devyded." $\mathrm{He}$ gathers his physical, sensible, rational and spiritual being together into a living allegory and a microcosm. He also "hevyth up the heved (that is to seyn, that it [thilke knowynge in our soule] hevyth up the entencioun) to ryght heye thinges" (Boece, V. m 4.36-7). "Thilke knowynge in our soule" is an act rather than a body of unstable text. The gloss is careful to clarify that "it hevyth up the heved" means "it hevyth up the entencioun." looking beyond himself, the reader, pilgrim, knower or interpreter 'transcends' his spatiotemporal being since he comes to recognize his mortal limits. By gaining limits, his natural, spatio-temporal beingbecomes rounded up into a whole and complete entity. To pursue the divine referent of his intentionality beyond these limits, the hermeneutical

\footnotetext{
${ }^{5}$ For Minnis' comparison of this gloss to Trevet see A. J. Minnis, Chaucer's Boece and the Medieval Tradition of Boethius, Chaucer Studies 18 (Rochester, NY: Boydell \& Brewer Ltd, 1993), 162 n. 36-37.
} 
pilgrim must take the leap beyond those limits to the divine goal he desires and seeks. As he makes this leap, his being exceeds the entire universe of which he is a microcosm. Union with God is deification "by the participacioun of dyvinite." "Right as by the getynge of justise [men ben maked just], and be the getynge of sapience thei ben maked wise, ryght so nedes by the semblable resoun, whan they han geten dyvinite thei ben maked goddes." (III, P. 10.142-150) But the journey does not end there. While Chaucer has radical differences with the alchemical natural philosopher, particularly where he the latter turns to occult forms of belief, he shares with him that extra step added to the traditional contemplative Christian journey to union with God. This is the recoil of the pilgrim's union with God back onto his life on earth, and its embodiment in his renewed being and actions, and in the wisdom he has acquired. This return element is also found in Boethius. Chaucer translates it as follows:

and whan it [thilke knowynge in our soule] retorneth into hymself it reproveth and destroyeth the false thingis by the trewe thinges. Certes this strengthe is cause more efficient, and mochel more myghty to seen and to knowe thinges, than thilke cause that suffrith and resceyveth the notes and the figures empressid in manere of matere. (V. m 4. 39-45)

After one has "gadre[d] togidre all thingis devyded" in his being, has "hevy[d] up the heved" and "entencioun" to God and has established communion with Him, "[thilke knowynge in our soule] "retorneth" and "destroyeth the false thingis." For Ripley and Norton, the person who has sought God beyond his own mortal limits and has had communion with Him, is reborn on earth in the perfected form of the "philosopher's stone" which continues to exceed the world even while living and moving within it. They would have perceived Boethian Chaucer's reader in the same light. The mind that has risen above the natural world and natural reason, like the philosopher who has visited the realm of Plato's forms, is no longer limited to "resceyv[ing] the notes and the figures 
empressid in manere of matere." He perceives the plenitude of things, and the entire architecture of being, in which every part is also a whole.

Chaucer's influence has been described as "something to which there is hardly a parallel in literature."6 The two alchemical poets whose work the next chapters study, George Ripley and Thomas Norton, were seen, and saw themselves, as Chaucerian poets. They composed their poetry in the aftermath of his monumental poetic, cultural and intellectual contribution, and of the turning point which he both represented and achieved, of secularizing the sacred and sanctifying the secular. What they perceived themselves to share with Chaucer can tell us much about the depth and breadth of the intellectual and poetic appreciation Chaucer received. Their own appreciation can in fact tell us not only about Chaucer's reception during the next century but also about the nature of Chaucer's own work, since they were relatively among the first to cull the implications and effects of this work, and to live at the turning point from the medieval to the modern. They were close enough to perceive the poetic, religious, philosophical, social and political actions Chaucer performed through his narrative poetry. They were close enough to feel the resonance of these actions in their lives and in their own poetic aspirations.

Although Chaucer scholarship since Skeat's 1894 publication of his works, is not in its infancy, it is by no means mature, and still young compared to the over six centuries that have passed since his death. Chaucer's appreciation began during his lifetime, and continued into the sixteenth-century, well beyond Ripley and Norton's fifteenth. Even "in Shakespeare's time" there is no question that between Chaucer and Shakespeare, the

\footnotetext{
${ }^{6}$ George Saintsbury, “The English Chaucerians: Lydgate," in Ward \& Trent, et al., The Cambridge history of English and American literature: An encyclopedia in eighteen volumes, Vol. II, The End of the Middle Ages (New York: G.P. Putnam's Sons; Cambridge, England: University Press, 1907-21), New York: Bartleby.com, 2000 (www.bartleby.com/cambridge/), paragraph 1.
} 
former received incomparably more appreciation. ${ }^{7}$ However, this appreciation, evident in the work of other poets and in historical events and records, did not include actual 'studies' of his work that could expound it to future generations. By the seventeenthcentury, language, fashions and world-views had changed. It is precisely the sort of change that Chaucer had worried about towards the end of his Troilus and Criseyde, when he sent his "litel bok" up to God for safekeeping from future misunderstandings due to linguistic and historical change: "And for there is gret diversite / In English and in writing of oure tonge, / So prey I God that none myswrite the, ..." (V, 1793-95). He also expresses the same idea in the prohemium to Book II: "Ye knowe ek that in forme of speche is change / Withinne a thousand yeer, and wordes tho / That hadden pris, now wonder nyce and straunge / Us thinketh hem" (II, 22-25). Chaucer, however, circumscribed this inevitable change of worldly circumstances within the greater power of "God thi [the 'litel bok's'] makere" (V, 1786). The idea that God will preserve the poem's truth through linguistic changes implies that the poem's significance exceeds the linguistic power of its text, and that the poet is an agent of divine truth. Chaucer combines the 'litel bok's' roots in God with its roots in the great poets of the past, "Virgile, Ovide, Omer, Lucan and Stace." Through this association he implies that great poetry, even that of pagan poets, is also rooted in divine truth. From its rootedness in God and in its author's reverence for these poets, this "litel bok" earns a transcendence of time similar to theirs.

One must fill in the gaps at this point and emphasize that Chaucer is including his lowly vernacular English poetry with that of the great and immortal Greek and Latin

\footnotetext{
${ }^{7}$ Caroline Frances Spurgeon, Five Hundred Years of Chaucer Criticism and Allusion (1357-1900): Introduction, Chaucer Society, Second Series, vol. 55 (London: Humphrey Milford, Oxford University Press, 1914-[25]), vi.
} 
poets of the past. In the prohemium to Book II, he follows his mention of linguistic change with an assertion that although the people of the past "spak hem so," i.e., in words "wonder nyce and straunge," they nevertheless "spedde as wel in love as men now / Ek for to wynnwn love in sondry ages" (II, 24-27). In these lines Chaucer emphasizes the common intentionality of human beings, including the pagan people of the past. $\mathrm{He}$ establishes the idea of continuity between the past and present people's structure of experience. He chooses love as the common factor. In his next line, "In sondry londes, sondry ben usages" (II, 28) he includes not only peoples of the past but also peoples of other lands and cultures. The phrase "sondry usages" implies different ways of using language for the same ultimate human intentionality. He continues to emphasize even further, the unity of human intentionality that underlies change: "For every wight which that to Rome went, / Halt nat o path, or alwaey o manere" (II, 36-37). This is clearly similar to the Boethian rootedness of all intentionality in God, the ultimate Good which includes all goods one might desire. Chaucer prays to God that his "litel bok" transcend the linguistic and circumstantial changes of the world.

Chaucer's concern about linguistic change proved to be prophetic. According to Spurgeon, during the seventeenth and eighteenth centuries Chaucer came to be "obsolete," with readers finding him "difficult to understand," and concluding that his style was "rough and unpolished." Even when Dryden dubbed him the "father of English poetry" and brought some attention back to him in his Fables Ancient and Modern, in 1700, he did so by 'modernizing' and 'refining' him. This Chaucerian demise did not begin to wane until 1775, when Tyrwhitt published his edition of the Cantrerbury Tales, recognized him as a literary craftsman, and made his work available for scholarly study. ${ }^{\mathbf{8}}$

\footnotetext{
${ }^{8}$ Ibid., vi.
} 
However, it was long until this demise actually waned. Spurgeon, who began the project of a history of "Chaucer criticism and allusion" at Furnivall's behest in 1901, 9 states that the attitude towards Chaucer as being coarse and in need of improvement and modernization, continued until 1841, the date the last "modernized" Chaucer was published. By that time however, attitudes had begun to change. In 1868 the Chaucer Society was founded and 1894 Skeat produced his scholarly edition of Chaucer's complete works. $^{\mathbf{1 0}}$ This means that it was not until 1894 that Chaucer scholarship was truly launched.

Although, since then, we have witnessed a growing intensity and wealth of Chaucer scholarship, we have not yet fully addressed or comprehended the depth and magnitude of the many new things he was doing or the many forces he was orchestrating and transforming, through his narrative poetry. We have not yet fully comprehended what these new things and transformations looked like and felt like, from the perspective of someone who did not, as we do, live so far on the other side of the transformation Chaucer had worked to accomplish, and the awareness he had worked to embody.

The two major fifteenth-century alchemical poets, Ripley and Norton, wrote at a time that still closely felt the intellectual transformations, poetical innovations and cultural re-interpretations that Chaucer's work had come to symbolize and embody, and were among the poets who continued to incorporate into their own poetry the themes and inner structures they perceived to be inherent in his. While formal versification in rhyme royal or couplet is the feature that has been commonly noted regarding the "Chaucerian poets'," Ripley and Norton's imitation of Chaucer, these two poets aligned themselves with Chaucer in far more substantial ways. Ripley wrote the Compound of Alchemy in

\footnotetext{
${ }^{9}$ Ibid., v.

${ }^{10}$ Ibid, p. vi.
} 
rhyme royal—seven line stanzas rhyming ababbcc — and Norton wrote the Ordinal of Alchemy in "exceedingly irregular heroic couplets, often shortening themselves to octosyllables." 11 Neither of them, however, were great versifiers, though Ripley was the better one. Where, in the sixteenth-century, Ascham ranked " 'Th. Norton, of Bristow' with Chaucer, Surrey, Wyatt and Phaer as having made the best that could be made of the bad business of riming verse,"12 the early twentieth-century Cambridge history of English and American literature remarks that that only shows "how entirely insensible [Ascham] was to true English prosody." ${ }^{, 13}$ Nevertheless, both poets perceived themselves inheritors of Chaucer's legacy in far deeper ways.

Ripley and Norton's association with Chaucer may have been, at least in part, a way for them to gain in status. It would also have helped them to insert their alchemical natural philosophy and beliefs into the literary heritage of England and perhaps even the continent. Yet they truly and earnestly shared with Chaucer several concerns and intellectual and formal principles. In fact, in spite of their shortcomings, each of them helps illuminate things that Chaucer himself was doing with language and poetic structure. They help illuminate his understanding of 'character' as 'person' and as a developing and changing subject. They help illuminate the influence of the scientific and philosophical ideas that came with the translated texts from Arabic. They also help place English literature within a wider geographical context that includes continental Europe and Mediterranean and Near Eastern cultures, and the widest possible historical context that included Ancient Greek and Roman literatures and philosophies, and that went even

\footnotetext{
${ }^{11}$ Saintsbury, "The English Chaucerians: Thomas Norton," in Ward \& Trent, et al., eds., The Cambridge History of English and American Literature: An encyclopedia in eighteen volumes, vol. II: The End of the Middle Ages (New York: G.P. Putnam's Sons; Cambridge, England: University Press, 1907-21), Bartleby.com, $2000<w w w . b a r t l e b y . c o m / c a m b r i d g e />$, paragraph 33.

12 Ibid., paragraph 34.

13 Ibid.
} 
further back, to include the history of all of humanity. With Chaucer they shared the idea of their poetry as agent in an action far greater than their own, one which encompassed not only the reader's activity, but that of the whole of nature as well, and whose ultimate actant was "God your auctour and yowr makere" (Boece, III, M.6.1-14). Ripley and Norton's indulgence in alchemical lore and in its deep theoretical as well as textual roots also helps bring into focus elements that had already begun to influence the understanding of poesis and the concept of literary production since at least the $12^{\text {th }} \mathrm{c}$.

Kahn points out that even to date (Nov. 2010), alchemical poetry-which is multiple in shape and form, and which existed as early as the $6^{\text {th }} \mathrm{c}$. in the context of Greek Byzantine alchemy_- "has been little studied." He points out that it is far from monolithic, and that "while a full account awaits the attention of a great Hellenist or Arabist scholar, we may nonetheless infer that alchemical poetry flourished in all cultures where alchemy developed."14 Kahn is speaking only of alchemical poetry in the strict sense of poetry which openly and directly had alchemy as its topic. This study of Ripley and Norton in the wake of Chaucer's poetry, however, serves towards our understanding of the implications and influence of alchemical philosophy and its paradigms for the concept of literary production, the ways in which mainstream, non-alchemical Late Medieval, and perhaps Early Modern, authors used it, and the significance that they attached to it. To come to such an understanding stipulates placing these alchemical paradigms within the larger context of the mainstream philosophical and theological ideas, and the imagery and language they commanded. It stipulates one's development of an awareness not only of the alchemical language and images that these poets have amalgamated with their own, but also how they may have used the paradigm of

\footnotetext{
${ }^{14}$ Didier Kahn, "Alchemical Poetry in Medieval and Early Modern Europe: A Preliminary Survey and Synthesis Part I - Preliminary Survey,” Ambix 57, no. 3 (November 2010): 249-74, 249-50).
} 
alchemical transmutation in their work's architecture of signification, and how it may have participated in forming their and their readers' relationship to the text as its producers.

\section{The Ancient Problem of Infinity and its Medieval Solution}

Much of the late medieval author's conception of the sensible world as governed by instability and constant flux, is based on the philosophies he inherited from Classical Antiquity which problematized the very possibility of entitihood, personhood and meaning: the problem of the infinity, relativity and incommensurability of time, which is the raw material of language, narrative, and the unfolding of meaning. To consider the relationship a late medieval author may have perceived, or deliberately set up, between narrative and temporality, the present day reader must consciously cross backward through fiction as we know it, and land way back on the anterior side of the rise of the modern novel, within a period that was decidedly different, and located at a far and safe enough distance from the sixteenth-century when Copernicus published his De revolutionibus orbium coelestium (On the Revolutions of the Celestial Spheres,1543) and especially when Thomas Digges disbanded the Primum Mobile (1576), and dispersed its stars into infinitely receding space, thus displacing the firmly bounded Ptolemaic and essentially allegorical universe with a spatio-temporally infinite, all-encompassing, and simply 'factual' one. The delightfully literal narrative journey that a Tom Jones (1749) or a Robinson Crusoe (1719) offers its readers betrays no anguish suffered over Heraclitus' river of time, Zeno's motionless arrow or Achilles' impossible race against the turtle, or with questions of how temporally conditioned perception could be transcended. Rather, to borrow Professor A. C. Spearing's words across to the context of the earliest "modern" 
novels, these were texts "whose meaning is not on the other side of [their] language, but is created in [their] language."15

Late medieval authors, however, did not take narrative cohesion as a given. While they were generally concerned with redemption and transformation, the bond, for them, between transformation and the narrative sequence through which it must unfold, was by no means unproblematic. Transformation requires the preservation of identity through the ongoing change. For the operation to be successful, the entity with which it begins must be the same entity with which its ends. Late medieval culture had strong concerns about the unreality or the low degree of 'existence' in the spatio-temporally contained mode of life within which change unfolds. It had strong concerns about sensible perception when unchecked and unaccompanied by other modes of being and knowledge. Time and space are infinite, and infinity is incommensurable. No event is possible within it. Any "moment" in it that one may hypothetically single out, is itself infinitely divisible, and other than itself. Beginningless and endless time is as ungraspable as the void and cannot produce history. Both Plato and Aristotle have equated quantitative infinity with unreality, and so has Aquinas. ${ }^{\mathbf{1 6}}$

In his Physics Aristotle explains that "the infinite qua infinite is unknowable, so that what is infinite in multitude or size is unknowable in quantity, and what is infinite in variety of kind is unknowable in quality. But the principles in question are infinite both in multitude and in kind" (Physics Bk I, Part 1, 187b7). In On Generation and Corruption, Book I, Chapter $8,{ }^{17}$ Aristotle discusses the topic to which fifteenth-century Thomas Norton refers as "the science de pleno \& vacuo" (Ordinal, V, 1686). Aristotle criticizes

\footnotetext{
${ }^{15}$ A. C. Spearing, "Language and its limits : The cloud of unknowing and Pearl" in Approaching medieval English anchoritic and mystical texts, eds. Dee Dyas, Valerie Edden and Roger Ellis (Rochester NY: D.S. Brewer, 2005), 75-86, 75.

${ }^{16}$ See page 22 and n. 22 in this document,

${ }^{17}$ H. H. Joachim, trans. On Generation and Corruption (Oxford, The Clarendon Press, 1922).
} 
those among "older philosophers" who argue that being must be an indivisible and motionless "one." He also criticizes the opposite kind of philosophers, who argue that being is "many," and he comments as follows:

... if it [the universe] is divisible through and through, there is no 'one', and therefore no 'many' either, but the Whole is void; while to maintain that it is divisible at some points, but not at others, looks like an arbitrary fiction. For up to what limit is it divisible? And for what reason is part of the Whole indivisible, i.e. a plenum, and part divided? (Bk I, 8.I, 324b2535)

What is divisible through and through has no more being than a "void." It is empty, or "vacuo" as Norton refers to it. In contrast, what is wholly indivisible-which, in the spatial way of thinking, would be the unit or particle that remains when divisibility reaches its limit—is a "plenum." It is "full," or "pleno," and has being. If, as some assert, the universe is divisible through and through, then there can be no being, since what is divisible through and through is void and without being. For there to be being, there has to be a unit that is indivisible. But any limit we may designate (conceived spatially) would be merely hypothetical, no more than "arbitrary fiction." How do we determine where the divisibility stops and being, or the "plenum" begins? There has to be a point of contact - a boundary—where the "pleno" comes to an end and meets something ontologically other than itself. Aristotle explains the way some have sought to avoid this problem: Others "assert that the universe is 'one' and immovable. Some of these add that it is 'infinite', since the limit (if it had one) would be a limit against the void,"18 and the void was either impossible or had no being. What is not is nothing. 'Nothing' cannot actively draw a boundary to being. Regarding those, however, who argue that being is indivisible, absolutely homogenous and infinite, cannot account for the "coming-to-be" and "passing- away" that is observable in nature. Some, including Empedocles, try to

18 Ibid., Book I.8. 
avoid this problem by arguing that the motion occurs through pores within the "plenum." These pores may be vacuous or filled with a different substance. ${ }^{19}$ Others, the atomists who include Democritus, argue that bodies, i.e., the "plenum," move within the void. ${ }^{\mathbf{2 0}}$ Aristotle criticizes more vehemently the former group which state that being is motionless and infinite, but he nevertheless criticizes the atomists as well.

Aristotle criticizes the atomists as well since, he argues, just like the void itself, "bodies are [also] divisible through and through.", Matter, in other words, is no different from the void. When conceived of spatially, both are infinitely divisible. The answer that Aristotle presents to this problem of how to account for "coming-to-be" and "passing-away," turns the entire issue around and brings in a new conception of reality, truth and change. The Pre-Socratic philosophers had conceived of the problem and proposed their solutions in spatial terms. Aristotle turned the conception of the 'change' around, from a matter of spatial differentiation into a matter of "action" enacted by an "agent": an issue of transformative, intentional, seeking, and personal action. Be it "matter" or "void," and for that matter, be it Space or Time, the infinite is the "potentiality" and the raw material from which the entity begins and moves towards actualizing itself. 'Being' is not spatial. 'Being' is 'Action'; and God, who is at once the Prime Mover and the ultimate goal of love and underlying intentionality, is pure 'Act'. Action is not equal to surface change and spatial movement. These in themselves cannot be action. But they can be action if understood as part of a greater ontological structure. What we may speak of as a 'being', an 'entity' a 'person' or a 'plenum' is so on the basis of its intentional motion towards a goal. A crucial concept which Bonaventure and

\footnotetext{
19 Ibid.

20 Ibid.

21 Ibid.
} 
Aquinas make use of, is the idea that the trajectory of the entity's movement from potentiality to actuality is guided by, or 'imitates,' the inner form or personal architecture of the intentional goal which that entity seeks. By seeking its goal, the entity "imitates" it in the Aristotelian sense of enacting the form of that goal in time, since "the likeness of the thing understood is the form of the intellect" (ST, I Q.85.Art.2) ${ }^{\mathbf{2 2}}$ By enacting its goal's form, the entity unites itself with that goal. For the alchemist this implies that the "Stone" - which Chapter Two argues is also the hermeneutic reader's mind—will acquire the form of the referent of its intentionality. This referent must be a being beyond the stone itself. This is true in Aristotle's concept of wisdom and prudence, action and art which he expounds in his Ethics and other major books, as well as in his definition of plot, art and tragedy in his Poetics. While an elucidation of Aristotle's discussion of these concepts is beyond the practical confines of this study, the form of the journey that is discussed and elucidated in the following chapters, is deeply influenced by Aristotle, as are the authors of these journeys, even while they fuse the Aristotelian form of the journey with the Neo-Platonic one. I do refer, in this introductory chapter and in this dissertation as a whole, to some of his concepts.

From the medieval Christian viewpoint, however, such as Bonaventure's and Aquinas' an important juncture is missing in Aristotle's scheme. Aristotle insists that a being with entitihood is finite, and that it acquires its entitihood and form through action, which he conceives of in terms of the seeking of a desired goal, which seeking, in turn, participates in a larger and more inclusive creative action. From a Thomistic or Bonaventurian view-point, however, Aristotle, while he insisted that an entity-which

\footnotetext{
${ }^{22}$ Unless otherwise stated, all Summa Theologica citations are from St. Thomas Aquinas, Summa Theologica: First Complete American Edition in three Volumes, vol. I, tr. Fathers of the English Dominican Province (New York: Benziger Bros., Inc., 1947), CCEL, http://www.ccel.org/ccel/aquinas/summa.html, np.
} 
substantially consists of its action - has a beginning, middle and end, he yet did not provide an answer to the question of how it is that anything can begin to rise out of potentiality and infinite divisibility and into actuality and form, when in its state of potentiality that entity is, to begin with, no more than an indiscriminate part of an infinity of non-being. The distance between the infinite and any beginning is itself infinite. The medieval Christian answer to that dilemma is that it can only occur through grace, and particularly through Christ's Incarnation (the beginning), as well as death-andResurrection (the end). The Resurrection leads to the beginning again, but now the beginning of a redeemed, permanent and perfect life.

Through the Incarnation it was possible to harmonize Plato with Aristotle. Aristotle insisted that God was pure Act, and that all genuine action participated in a larger, divine action. Since God as pure Act is also pure Creation, then all genuine action participated in Creation. God was the Prime Mover, and the ultimate goal of all actants. Aristotle insisted on the freedom of the action. But he did not explain how God first touched Man to move him without having him moved by physical and natural necessity. Plato, on the contrary, gave the Socratic theory of prelapsarian remembrance as an explanation of how God reached and moved man freely through love. But he rejected the very temporality through which the inspired human being then turned his prelapsarian vision into his goal "out there," and enacted and unfolded the form of this goal in time. The Incarnation united the two perspectives and made them work together, since Christ was both beyond the temporal world as well as within it, in a union that only God could make. He was both within man and yet beyond his mind. Man could both "remember" Him from within, through prelapsarian memory, and seek him without, as a goal beyond himself, towards which he can move through his own actions. In this way the human 
being has boundaries and form. He has limits given to him by the divine being that exists prior to his action, and that he comes into contact with through Platonic remembrance. He also has limits in terms of the 'end' of his action, since his goal is beyond himself.

Bonaventure and Aquinas' systems were essentially such a union of the inner with the outer, of eternity with time. But the "within" for them was not a Romantic within. It was an encounter with the boundary at which man freely and intentionally received divine Grace: what God, unambiguously beyond this boundary, gave. Similarly, for Bonaventure and Aquinas, the "without" was not a spatially conceived and absolutized self-subsistent reality without end, as it was to become again after the scientific revolution. The "without," too, was for them an encounter with boundaries. Its journey was temporal. But it unfolded temporally and spatially in the seeking of a goal that was beyond both time and space. The boundaries one met without, were the same boundaries through which one received the divine inspiration from within. The prelapsarian visionary entity that a person 'remembered' and thus began seeking, is the same as the divine goal he or she seeks. These boundaries were the Incarnate Christ Himself, as discussed in the comparative study Chapter Three makes between Bonaventure and Ripley.

In the thirteenth-century, Aquinas, who had commissioned William of Moerbeke's translation of the rediscovered Aristotle, concurs with Aristotle's description of quantitative infinity as pure privation, non-being and nothing: In the Summa Contra Gentiles, he explains that God's infinity is not the same kind of infinity we understand sensibly, spatio-temporally, or even abstractly: "[God] is not said to be infinite by way of privation, as is quantity. The infinite of this kind is quite logically unknown, because it is like matter devoid of form, which is the principle of knowledge" ( $S C G 56$, reply obj.s 4 
and 5). ${ }^{\mathbf{2 3}}$ Time, then, is formless, and, at best, it can be regarded as raw material, or "Hyle," and as such, pure potentiality. At worst, though, it is pure privation, from which nothing can begin, and no real change can occur. The idea that without God the initial and initiating event cannot occur offers an insight into the Christian doctrine, such as held by Augustine, that God created potentiality.

As regarding Plato, while the majority of his works, apart from the Timaeus, were not available until Marsilio Ficino's translation of them in the fifteenth-century, they were partly known through numerous secondary sources. For example, in Seneca's description of Plato's six-tiered ladder of being, the sensible world was to Plato a bare degree higher than the infinite void on the scale of existence. ${ }^{24}$ Its flux was conditioned by the incommensurability of infinity and the annihilating fragmentation and relativity of spatiotemporal flow. Logically, therefore, infinite time and space and, as such, their hypothetical narrative sequence, were ineligible for the project of transformation.

Concern over the question of flux, and the very possibility of identity or transformation at least partly underlay the medieval emphasis on transcendence. This concern is particularly evident in medieval narratives of the contemplative or mystical rise towards union with God. In Chaucer's translation of Boethius' Consolation of Philosophy, Philosophie, who had defined eternity as a 'gathering together' of the infinity of time into a whole and a single moment of divine presence, tells Boethius that that which is conditioned by time, "althoughe that the lif of it be strecchid with infinite of tyme," yet it does not comprehend the whole. "Eternite . . is parfit possessioun and al togidre of lif interminable." In contrast, "thilke thing that suffreth temporel condicioun,"

\footnotetext{
${ }^{23}$ Anton C. Pegis, ed., Introduction to Saint Thomas Aquinas (New York: The Modern Library, 1948), 17677.

${ }^{24}$ Richard Mott Gummere, tr., Seneca, Ad Lucilium epistulae morales: with an English translation, (3 vols), vol. 1, eds. E. Capps, T. E. Page and W. H. Rouse (London: William Heinemann Limited, 1918, rpt. 1925), 401.
} 
and which "nevere bygan to be," and "nevere ne cese for to be, as Aristotile deemed of the world," cannot gather its life into a whole. "It ne enbraseth it nat the space of the lif al togidre;" since "certis yit ne hath it nat taken the tyme of tomorwe, and it hath lost that of yusterday, and certes in the lif of this dai ye ne lyve namore but right as in this moevable and transitorie moment" (V, P. 6: 11-41). It is one thing, she explains, "to ben ilad by lif interminable, as Plato grauntide to the world," and another thing "to enbrace togidre al the presence of the lif intermynable," which is "propre to the devyne thought" $(\mathrm{V}, \mathrm{P}$. 6: 59-64). The same idea is a formal principle in Bonaventure's Itinerarium Mentis in Deum, or The Journey of the Mind Into God. The divine Intellect in its eternal and allembracing presence, transcends the infinity of time and space, and in this sense binds them into limits, transforms them into unified categories, and assigns them a particular and limited place within the ontological structure of being. It is only in seeking an ineffable God located beyond the entire ontological structure of the macrocosm, and beyond the limits of one's own mind, that the individual human being can rise beyond his natural existence, and his natural power of reason, and thus be 'gathered together' into a whole and a "microcosm.",25 Even Aristotle's emphasis on Time and Space as categories - an emphasis later reiterated by Immanuel Kant to construct his own account of the limits of Reason — renders their infinity subject to intellectual limits, and opens the mind to an awareness that its being, or presence, exceeds time and space, if only due to the fact that it can reduce them into categories. To the medieval understanding, however, this reduction can only be performed through Grace.

\footnotetext{
${ }^{25}$ See George Boas' introduction in George Boas, ed. and trans., The Mind's Road to God (Upper Saddle River, NJ: Prentice Hall, 1953, rp. George Boas, trans., Journey of the Mind into God-St Bonaventure, Crossroads Initiative, Web, http://www.crossroadsinitiative.com/library_article/666/Journey_of_the_Mind_into_God_St_Bonaventure. html, np., accessed April 8, 2014. See also Chapter 3 in this document.
} 
One of the popular ways in which medieval literature and lore portrayed the privation of infinity is in the figures of its gargoyles, dragons and monsters, such as the large monstrous hell-mouth that was represented in medieval religious engravings or at the bottom corner of the stage in medieval cycle-plays, or as the gargoyles along the roofs of Notre Dame Cathedral, which metaphorically swallow the rain water away into the bottomless abyss. Another example is the basilisk which kills with its glance, and to which Ripley likens Mercury's poisonous medicine which must kill in order to heal. ${ }^{\mathbf{2 6}}$ A well-known example is the figure of Medusa, which turns into stone whoever looks her in the face. In the Inferno Virgil makes Dante cover his eyes while passing Medusa (Inferno, Circle 5, canto 9, lines 49-55), ${ }^{\mathbf{2 7}}$ since Dante was not yet ready to recognize privation or non-being for what it was, and was still likely to mistake empty appearance for reality, and thus to mistakenly treat it as an object of knowledge. This incident illustrates that Parmenides' argument of the falsehood involved in treating non-being as an object of knowledge, came to be more deeply understood and more fully articulated during the Middle Ages. But as opposed to Parmenides, who denied that there could be any truth in language when it referred to privation, Aquinas defended the human being's ability to speak of privation truthfully, since it is crucial to recognize privation and evil for what they are. He, like Aristotle, argues that privation is unknowable and has no essence. But one can recognize the truth of its privation and speak of it by analogy with being, which is knowable. The only way we can "know" it is by knowing it for what it is: non-being. But we can only know privation for what it is through knowing being, and by analogy with that which is knowable, viz., being. For example, he argues:

\footnotetext{
${ }^{26}$ For Ripley's use of the image of the basilisk see of his "Recapitualion [Recapitulatio totius operis praedicti]" 11.4, and his "Epistle to King Edward the 4" 26.8 and 28.8 in Stanton Linden, George Ripley's Compound, 84 and 95-6.

${ }^{27}$ John D. Sinclair, ed. and tr., The Divine Comedy of Dante Alighieri: 1 Inferno (New York: Oxford University Press, 1979), 123.
} 
Non being and privation have no truth of themselves, but only in the apprehension of the intellect. Now all apprehension of the intellect is from God. Hence all the truth that exists in the statement- "that this person commits fornication is true," - is entirely from God. But to argue, therefore, that this person fornicates is from God, is a fallacy of accident. (ST I, q.16. a.5, reply obj. 3).

Grave danger lies in failing to recognize privation for what it is, and in mistaking it for being and treating it as though it were an object of knowledge. The soul according to Aquinas or Dante, 'imitates,' and in doing so acquires the form of the object of its knowledge, the object on which it is affectively intent or which it intellectually contemplates. According to Aristotelian Aquinas, the temporal trajectory of the soul's movement bears a formal relation to the goal of its movement. In explaining this, Aquinas states:

I answer that,..., it follows that the soul knows external things by means of its intelligible species.

Reply to Objection 1: The thing understood is in the intellect by its own likeness; and it is in this sense that we say that the thing actually understood is the intellect in act, because the likeness of the thing understood is the form of the intellect, as the likeness of a sensible thing is the form of the sense in act. (ST, I q.85.a.2)

Through its operation of knowledge, at first directed at creatures, the soul is gradually guided to God who is pure Act and pure Creation, as its ultimate goal. The various particular and spatio-temporally known beings, which the soul contemplates, and treats as objects of love and knowledge, on its way to its divine goal, become figures of this goal. These figures become participants in, and agents of, the divine Act of Creation, as Beatrice was for Dante. Since "the thing actually understood is the intellect in act" (emphasis my own), the objects the soul perceives are themselves acts of creationembodiments of these acts - in which the soul comes to participate, through its operation of knowledge. But what would happen if the object which the ignorant soul contemplates 
or desires, and moves towards, is an illusion and a non-being? That soul would be shattered, which is ignorant of its ignorance, and which relates to non-being as though it were being. Medusa "turns" her patient to stone by inverse analogy to the idea that God turns into His likeness all those who come to know Him: "when He shall appear we shall be like to Him, because we shall see Him as He is." ${ }^{\text {28 }}$ When the soul moves towards the created good in proportion as that good has the likeness of God, its movement imitates, in time, the form of this likeness, which is ultimately the pure act, or form, of God. The movement of the soul is its substance. So, by moving towards the likeness of God, the soul becomes more like Him (not 'god-like' in a generic sense, as though there had been a species of gods, but like Him as a personally known and loved, absolutely unique being) as it actualizes itself, in time, into the form of this likeness. By analogy, when the soul moves towards a non-being, or privation, like Medusa, the soul imitates the formal principle of privation, ${ }^{\mathbf{2 9}}$ which is an incommensurable and formless infinity. Thus, whoever sees Medusa is turned into formless and undesignated matter, a privation signified by lifeless, generic stone. The soul would be caught in the incommensurability of infinity, and, like pure matter or generic stone, dispossessed of free will, and incapable of self-motion.

The question then remains, how can the fallen intellectual soul, immersed in time and infinite relativity, even begin to know, and to actually move towards any truly existent object? By the same logic, how can narrative have any stable foundation and

\footnotetext{
${ }^{28}$ Aquinas, quoting I John iii.2 in SCG 51, in Pegis, Introduction to Saint Thomas Aquinas, 469.

${ }^{29}$ For a discussion of Medusa, partly in connection with fragmentation and temporality, see John Freccero, Dante: The Poetics of Conversion, ed. Rachel Jacoff (Harvard University Press, 1986), 119-135. "the threat of the Medusa proffered by the Furies represents, in the pilgrim's askesis, a sensual fascination and potential entrapment precluding all further progress" (126). Freccero argues that Dante's Medusa is "an interpretive as well as a moral threat," and that Dante's averting his eyes from her represents his averting his eyes from the temporally conditioned sensible illusions to look at the more enduring truths "beneath the veil" (121). He also describes Dante as a mediator for the reader's interpretation, performing, in his own turn, the role of Virgil towards the reader. (123). See also John Freccero, "On Dante's Medua" in Marjorie Garber and Nancy J. Vickers, eds., The Medusa Reader (New York: Routledge, 2003), 111-121.
} 
meaningful beginning, so that it can proceed from beginning to end? If time is formless, and if the fallen sensible world is mere flux without being, then how does a would-be pilgrim begin his journey, let alone move towards a goal and reach it? If privation, or even mere formless potentiality, are unknowable in themselves, if nothing can possess form except what is already in act, if similarly nothing can possibly be known except what is already possessed of form, and if, at the same time, the intellect cannot know unless it, too, is already in act, since knowledge is the act of coming to know, then how is it that the soul can get out of this vicious catch? The would-be pilgrim who has not yet begun, is still in a passive state, and one must therefore ask, if the person were in a passive state, as Dante the pilgrim was at the opening of the Divine Comedy, and if all he had around him were primal chaos, such as the "selva oscura" or such as the unstable flow of sensible appearances - that to a depressed person become meaningless anywaythen how can this would-be pilgrim even begin to know, to move and to cross the distance from privation or even potentiality to act, and from ignorance to knowledge? Dante's and Aquinas' reply, like that of innumerable other medieval Christian authors, was that it could only be done through Grace and Christ's mediation. As the chapters on Thomas Norton argue, Norton's allusion to the advent antiphon "O Sapientia" in his Ordinal of Alchemy (VI, 2719-26), ${ }^{\mathbf{3 0}}$ refers to the same problem in the form of the human condition of those "botirflyes" who "wondir and passe" (V, 2719), and do not possess the stability of mind to carry out the transformational work "Fro the begynnynge" through "the meen space" and all the way "to the ende." It also offers the Incarnation as the agent that enables the alchemist to complete the operation successfully. As the first two

\footnotetext{
${ }^{30}$ John Reidy, ed., Thomas Norton's Ordinal of Alchemy (Oxford: Oxford University Press for the Early English Text Society, 1975). All subsequent quotations from Norton's Ordinal are from this source, and will henceforth be cited only inline.
} 
chapters above have argued, George Ripley points to the same problem when he describes the false "philosophres" and multipliers who are immersed in temporality and sensible perception, and can only "separate" the stone "manually" instead of into its ontological parts. In both Thomas Norton as in George Ripley, the false philosophers' work is in a state of infinite deferral due to their immersion in the medias res of absolutized spatio-temporality. They are ignorant not because they have not read the texts, but because they are, like fish that live in the depths of the waters of sensiblity, and have never come to the surface or broken through it. They are ignorant of the possibility of another mode of being and knowledge, by virtue of which temporal moments acquire limits, form, meaning and identity.

Heraclitus' metaphor of the river into which one could not step twice, since the waters will have changed - and since not the most infinitesimal part of time that can be hypothetically imagined, is free of this flux — was well known during the high Middle Ages. It had been mentioned in numerous philosophical treatises, among which I quote, below, Seneca's discussion of its implications in a passage to which Chaucer alludes in the "Introduction to the Man of Law's Tale." Chaucer alludes to Heraclitus' river of time both in the "Introduction to the Man of Law's Tale" and in the prologue to his Clerk's Tale. Although the allusion, in the latter, is less directly disclosed, the reader's awareness of it is radically consequential to his grasp of the meaning of that tale. Both tales, in fact, offer striking examples of how much of the significance of Chaucer's symbolical language, and of the tale as a whole, the reader can miss if he pays no heed to Chaucer's allusions to the problem of the relativity of time, and the consequent infinite deferral of all that is conditioned by time. Consequently the reader would also miss the nature and depth of the healing Chaucer is offering through his tales. 
The "Introduction to the Man of Law's Tale," inaugurates Fragment II with pointed and detailed attention to time but in a natural, cosmic and cyclical context reminiscent, though in the lowly English vernacular, of Dante's references to cosmic time, which, although in Italian, are composed in serious high style. The voice of Chaucer, describing what "Oure Hoost saugh," defines the time at the present moment by placing each of its units within the gradually widening concentric cycles connected with "Phebus" cyclical journey. He includes in his description the whole range from the immediate-present "lengthe" of the "shadwe of every tree," through the hour of the day, the day of the month, and the month of the year. In addition to giving the present moment a cosmic dimension, this description dramatically deepens the perspective that roots the present moment in its place. The concentric circles place the concrete present momentembodied in the pilgrims" "body erect" (11) —at their center. The "body erect" emphasizes the immediacy of the concrete present moment, and its rootedness in the vast range of harmoniously aligned natural operations. Chaucer creates a similar rooting effect through the dramatic depth he creates between the ponderous cosmic perspective suggestive of the Dantesque high style on the one hand, and the very concrete and rugged immediacy of the Host's homely character and language and those of the pilgrims he addresses, on the other hand.

At the same time Chaucer creates another ironical layer of temporal perception, which presents time as speeding by and being wasted. A contrast is created between the orderly cosmic operations in which everything has its proper time and season, and the temporal flow of human activity which tends to run off on its own, in a formless manner that is disconnected from the cosmic order. It is a point not to be missed that the Host connects his call to the pilgrims to grasp the moment and not to let time slip formlessly 
by, with the ordered cosmic cycles of nature. While critics have correctly placed much emphasis on the irony between the Host's exhortations against wasting time, and the solution he gives, of passing the time through the telling of tales, more attention needs to be given to the clue that Chaucer is offering, through the Host's opening speech, as to the nature of narrative. Narrative similarly has two aspects. In one sense, it runs formlessly on, merely passing the time, but it also has the potential to align itself with the operations of nature, and to grasp the present moment.

The image the Host gives of the slippage of time in the lines that follow, dramatically and ironically contrasts with the orderly cycles of nature which, Chaucer's voice tells us, the Host "saugh." The Host's exhortation itself, in lines 16 to 31, against such slippage of time as he has described it, carries some irony. He mentions Seneca, and alludes to two opposite ideas both found in Seneca's epistles: on the one hand, the great value of time and the impossibility of replacing it when it is lost, and, on the other hand, the very impossibility of grasping it. The Host refers to Seneca "Biwaillen" time "moore than gold in cofre," and at the same time alludes to Heraclitus' river metaphor:

Leseth no tyme, as ferforth as ye may.

Lordynges, the tyme wasteth nyght and day, 20 And steleth from us, what pryvely slepynge, And what thurgh necligence in oure wakynge, As dooth the streem that turneth nevere agayn, Descendynge fro the montaigne into playn. Wel kan Senec and many a philosophre

Biwaillen tyme moore than gold in cofre; For los of catel may recovered be, But los of tyme shendeth us,' quod he. (19-28)

Larry Benson accepts Epistles 1.3 as the Senecan text to which the Host alludes. That passage emphasizes the value of time and the need to prevent its inadvertent slippage:

... hold every hour in your grasp. Lay hold of to-day's task, and you will not need to depend so much upon to-morrow's. While we are postponing, life speeds by. 3. Nothing, Lucilius, is ours, except time. We were 
entrusted by nature with the ownership of this single thing, so fleeting and slippery that anyone who will can oust us from possession. What fools these mortals be! They allow the cheapest and most useless things, which can easily be replaced, to be charged in the reckoning, after they have acquired them; but they never regard themselves as in debt when they have received some of that precious commodity, - time! And yet time is the one loan which even a grateful recipient cannot repay. (I. 2-3) ${ }^{\mathbf{3 1}}$

In this reference Seneca describes time as mankind's precious and irreplaceable possession and cautions Lucilius that people are easily robbed of this possession due to its "fleeting and slippery" nature. Although it does not mention the river metaphor, it clearly bears a relation to lines 19-22 in which the Host emphasizes the need to grasp time and prevent it from slipping by, as well as to line 24 in which Chaucer describes time as more valuable than "gold in cofre." In the opposition that Chaucer makes, however, between the "gold in cofre" that is time, and material possessions that are replaceable, he offers "catel" as example of the latter. Two images remain unaccounted for in the reference Benson, and before him Robinson identify. ${ }^{32}$ Both editors dismiss the image of the stream of time as a merely proverbial saying. Seneca does mention Heraclitus' river or stream metaphor, however, in his fifty eighth epistle. The image of cattle also occurs there in the context of Seneca's description of Plato's description of things that constantly pass away in time's flow. Certainly, there is nothing to prevent Chaucer from alluding simultaneously to more than one passage in Seneca's writings. His numerous allusions to Seneca in his works, give evidence of Chaucer's close familiarity with him. The notes to the Riverside Chaucer state 26 instances of such allusions, and Chaucer directly mentions Seneca's name 18 times. It is Seneca's fifty-eighth epistle that

\footnotetext{
${ }^{31}$ Gummere, Seneca, Ad Lucilium epistulae morales, 3-5.

${ }^{32}$ Robinson, ed., The Works of Geoffrey Chaucer (Boston: Houghton Mifflin Company, 1957), 690, note to line 20 .
} 
concurs with Chaucer's reference to the river metaphor and, though less significantly, to “catel.”

In the fifty-eighth epistle's considerably longer and more elaborate discussion of the fleetingness of time, Seneca quotes Heraclitus in connection with his above mentioned description of Plato's six gradations that range from being to non-being, which place time and the void in the sixth and last class, with no more than "fictitious" existence. After he explains that according to Plato sensible things do not strictly exist, Seneca proceeds to elaborate on the nature of time. He associates the flow of time with the flow of our own selves, and extends the resultant discontinuity of personal identity to things throughout the entire universe:

... in the sixth class goes all that which has a fictitious existence, like void, or time."

Whatever is concrete to the sight or touch, Plato does not include among the things which he believes to be existent in the strict sense of the term. These things are the first that have to do with us: here we have all such things as men, cattle, and things. For they are in a state of flux, constantly diminishing or increasing. None of us is the same man in old age that he was in youth; nor the same on the morrow as on the day preceding. Our bodies are hurried along like flowing waters; every visible object accompanies time in its flight; of the things which we see, nothing is fixed. Even I myself as I comment on this change, am changed myself. 23. This is just what Heraclitus says: "We go down twice into the same river, and yet into a different river." For the stream still keeps the same name, but the water has already flowed past. ... this prompts me to marvel at our madness in cleaving with great affection to such a fleeting thing as the body, and in fearing lest some day we may die, when every instant means the death of our previous condition. Will you not stop fearing lest that may happen once which really happens every day? 24. So much for man, - a substance that flows away and falls, exposed to every influence; but the universe, too, immortal and enduring as it is, changes and never remains the same. $(58.22-24)^{33}$

The "change" to which Seneca refers in connection with the flow of time is not the sort of change that can be called transformation, but the contrary, the fragmentation of identity-

${ }^{33}$ Ibid., 401. 
a constant slipping away of selfhood into alterity—as each ungraspable instant is infinitely other than itself, and as the person in time is also infinitely other than himself at any given point in time. The death Seneca refers to as taking place every instant is obviously not the alchemist's renewing kind of death through which the stone passes across the boundaries of the spatiotemporal world to the divine beyond, while, paradoxically, it retains and even perfects its own identity in that world. It is not the death through which the stone accomplishes the "alchemical marriage" within its being, between earth and heaven, body with spirit. Rather the opposite, it is precisely that fragmentation which alchemical natural philosophy seeks to overcome. It is the death of identity, the endless difference from oneself through the ceaseless flux of the sensible world. It is a death-in-life in which one's body is not one's own. In this passage Seneca associates the body with time. The body is subject to constant alterity from itself while trapped within the natural recycling of physical matter. Underlying Seneca's description is an association of time with matter. Time and matter, in their capacity as formless and boundless, become absolute, and afford no escape from inexorable alterity, fragmentation, and infinite death. This sort of death Chaucer contrasts to liminal experience and to death as a meaningful event and a purifying passage, as in The Second Nun's Tale of the martyrdom of St. Cecilia. He similarly contrasts flux, in which change is superficial and meaningless-since it is steeped in non-being-with the ideal accomplishment of the pilgrim's transformation. As opposed to the passive state of constant dying away in ceaseless flux, the pilgrim's passage through boundaries and death during transformation implies his experiential enactment and internalization of the ontological structure of being: In alchemical transformation the pilgrim enacts and internalizes the entire chain of being, as well as the corresponding layers of the operation 
of knowledge, until that same pilgrim breaks beyond even his cosmic limits and carries the entire structure, within him, into union with God.

\section{The Problem and its Solution in The Clerk's Tale}

In the prologue to the Clerk's Tale, the reference to the river of time, and its connection with the opening lines of the tale proper, are more veiled. But the focus on the problem of continuity of identity is unmistakable. Petrarch, who had translated the story of Grizelda from Boccaccio into Latin, and who, the Clerk tells us, is the source of his tale, had embellished Boccaccio's opening lines and added a description of the river Po rising from its source at the foot of "Mount Viso" and flowing through the plain below it and its many towns, until it opens with "great mouths" into the Adriatic. "Through Liguria its raging waters cut their way, and then, bounding Aemilia and Flaminia and Venetia, it empties at last into the Adriatic sea, through many mighty mouths. ${ }^{, 34}$ In the prologue to his tale, the Clerk refers to that description in Petrarch's "prohemye" (43). He makes this reference immediately after he has joined together the two opposites: Petrarch's immortal poetic honor and the event of his death. The Clerk first mentions Petrarch's high honor as a "laureate poete/ ..., whos rhetorike sweete/ Enlumyned al Ytaille of poetrie" (31-3). He then follows that implication of poetic immortality with the fact of his death, and the fact that death "will nat suffer us dwellen heer," and "alle shul we dye":

But deeth, that will nat suffer us dwellen heer,

But as it were a twynklyng of an ye,

Hem both hath slyn, and alle shul we dye (36-28)

\footnotetext{
${ }^{34}$ Francis Petrarch, "Tale of Griselda," Robert D. French, A Chaucer Handbook (New York, 1927), The Geoffrey Chaucer Page, prepared and maintained by Larry D. Benson (@ The President and Fellows of Harvard College, Last modified: May, 5, 2006).
} 
The fact that the Clerk's description of the flow of the river Po follows immediately after his mention that death will not suffer "us" to "dwellen" here, suggests that Chaucer intends the Clerk's language to allude to Heraclitus' metaphor of the river of time in which nothing can stay the same. The Clerk retells Petrarch's description of the river Po in his own words (39-51), clearly associating the river with Petrarch's "Ytaille." In his "prohemye" Petrarch, says the Clerk, "discryveth" "Pemond," "Saluces," the "hilles hye" of the Apennyn" (43-46). One must ask, why so much attention to the various parts and features of the country of Italy? One must also ask why the enjambment of the list of places into a single sentence, through nine lines, making ten to include the first line with which the Clerk introduces this list (43-52), and as much as fourteen lines from the beginning of that single sentence, to its end (39-52). At line 47 the Clerk's description performs a turn, although this turn might slip by the reader as no more than a part of this enjambment. He places "special" emphasis on "Mount Vesulus" and the welling of the river Po from it. The rest of the place-names follow the flow of the river:

And of Mount Vesulus in special, Where as the Poo out of a welle small Taketh his firste spryngiyng and his sours, That estward ay encresseth in his cours To Emele-ward, to Ferrare, and Venyse; The which a long thing were to devyse. (47-52)

Can we legitimately claim that Chaucer is deliberately using the river Po to suggest Heraclitus' river? One significant bit of evidence comes from the echo between the Clerk's description of the river Po flowing down from "Mount Vesulus" and the Host's reference to the river-or stream - of time in the "Introduction to the Man of Law's Tale." The Host says that "the tyme wasteth nyght and day,/ And steleth from us, . . , , As dooth the streem that turneth nevere agayn,/ Descending fro the mountaigne into the 
playn" (20-24), (the emphasis is my own). There is in Chaucer's mind the image of the "streem" of time descending from the mountain into the plain, exactly as does the river Po. Chaucer may also be associating the rive Po with narrative time. "To devyse" means "to recount," in addition to conveying the idea of craft. The long, fourteen line sentence, in which the Clerk describes the river Po, imitates the flow of the river. It even begins slow and speeds up, until an end that is no end, but only a deferral. It begins with the relaxed "But forth to tellen of this worthy man," and speeds up through the enjambment until "That estward ay encresseth in his cours/ To Emele-ward, to Ferrare, and Venyse," and finally allows the river to wind away down its course to an invisible end: "The which a long thing were to devyse." The deferral effect becomes even more emphatic when we note the way such an ending to the Clerk's narrative account differs from Petrarch's. Petrarch gives a geographical and objectified account of the river which "empties at last into the Adriatic sea, through many mighty mouths." ${ }^{\mathbf{3 5}}$ In contrast, the Clerk poetically imitates the course of the river through the country of Italy and into the distance, and associates it with deferral. Significantly also, in contrast with Petrarch's river which finally gushes out of the land of Italy and into the open sea, the Clerk allows the river to taper into the distance of that same country and into its unknown future. Chaucer's Po remains in Italy, its future identical with that of Italy's.

There is, however, a factor, built into the Clerk's description of the river Po, which contrasts and intersects with the idea of deferral, and intersects with the flow. This is his emphasis on the river's origin and beginning. From "Mount Vesulus," "the Poo out of a welle small/ Taketh his firste springing and his sours." Does Chaucer intend his reader to note the river's origin from the hidden and mysterious depths of the mountain,

${ }^{35}$ Ibid. 
and even to note its growth from a small well into a mighty river? Is the question of origins important?

We know that the tale of Walter and Grizelda is occasioned by Walter's people's concern over preserving their past identity, represented by Walter, and carrying it down into the future:

"Delivere us out of al this bisye drede, And taak a wyf, for hye Goddes sake!

For if it so bifelle, as God forbede, That thurgh youre deeth youre lynage sholde slake, And that a straunge successour sholde take Youre heritage, $\mathrm{O}$ wo were us alyve! Wherefore we pray you hastily to wyve."

Walter's people emphasize the subject of time, and significantly create a contrast between the purposeless and formless flow of time conditioning Walter's capricious passing of it in recreational activities on the one hand, and the idea that it is now time for him to get married, on the other hand. In doing so, they reflect the same contrast that emerges from the Host's speech (MLT, 1-30) at the opening of fragment II, between the orderly cycles of nature, at the center of which the body itself is anchored, and the slippage of time in formless human activity. The Clerk comments that

I blame hym thus, that he considereth noght In tyme comynge what hym myghte bityde, But in his lust present was al his thoght, As for to hauke and hunte on every syde.

Wel ny alle othere cures leet he slyde; (78-82)

The rhyme runs through "bityde" and "syde" to lay the stress on "slyde." The Clerk "blame[s]" Walter for leading a life of sliding time. The representative of the people's voice, who conveys their complaint and request to Walter, echoes the theme of time and death in the tale's prologue. He first asks Walter to think of the passage of time:

And thenketh, lord, among youre thoghtes wyse How that oure dayes passe in sondry wyse, 
For thogh we slepe, or wake, or rome, or ryde, Ay fleeth the tyme, it nyl no man abyde.

And thogh youre grene youthe floure as yit, In crepeth age alwey, as stille as stoon, And deeth manaceth every age, and smyt In ech estaat, for ther escapeth noon; And al so certein as we knowe echoon That we shul deye, as uncerteyn we alle Been of that day, whan deeth shal on us falle. (117-26)

To convince Walter, the people bind two poles of experience together: death and wisdom. They ask him to remember death, and they ask him to find that memory "among youre thoughtes wyse." The speaker posits wisdom, "youre thoughtes wyse," as the agent through which Walter will be able to remember death and change the temporal slippage that conditions his and their existence. The speaker thus makes death the fulcrum of change from one mode of living to another: from passing away the time to grasping it. Wisdom involves contact with the divine Intellect beyond time and space. As the body is anchored in the cycles of nature, so the human operation of knowledge is anchored in that which is beyond nature. He reminds Walter of the certainty of death for everyone, even though one does not know the day "whan deeth shal on us falle" (120-26). The people's concern about the passive slippage of time and their desire instead that Walter prudently act to grasp the time, is reminiscent of the Host's allusion to Ecclesiastes 3:1-8 at the very opening of the "Clerk's Prologue": "Salomon seith 'every thing hath tyme."” With their request, the people intercept the careless flow of Walter's life and ask him to do the right thing at the right time. The Old Testament idea that everything has a right time and a season reflects what time is like when it is redeemed, no longer fallen and slipping. As in the "Introduction to the Man of Law's Tale," Chaucer creates, through Walter's people's concerns, a contrast between ordered, meaningful time, and slipping-away time, 
and he organizes the consequent narrative unfolding of the Clerk's tale in response to the people's plea to Walter to grasp the time.

The connections between the tale and its prologue are deep and obviously deliberate, which raises the question of Petrarch's role in relation to the tale and its themes. The connections especially raise the question of why Chaucer would wish to relate Petrarch to the theme of time and identity. There is no doubt that Chaucer is tying Petrarch to the theme of time and to Italy, and in turn tying this cluster of meaning to the tale itself: The opening of the tale repeats again the picture of the lands below "Mount Vesulus," and repeats it in tandem with the idea of the passage of time. The opening of the tale, therefore, deliberately carries the "Clerk's Prologue's" referential structure and clusters of meaning into the tale proper. In these opening lines Chaucer touchingly combines the effect of a magnificent distance in both time and space with the homeliness and immediacy of the vernacular. The river Po is not specifically mentioned, but its presence has already been so stressed by the Clerk a few lines earlier, that the reader can hardly look at "the roote of Vesulus" with the "lusty playn, habundant of vitaille," with "many a tour and toun ... . That founded were in tyme of fadres olde," (57-61) and not picture it, in his mind's eye, with the river Po running through it. The connection with time is now undeniable. The language conveys with immediacy the constant presence of that thriving plain with its towers and towns through time, since it was built by the "fadres olde." Within the same constant presence of the present moment of the river's flow and the people's continuing activity, the "fadres olde" built the towns and towers, and the present people live in them. The "fadres olde" inhabited the present moment of the plain as do their descendants now. It is the same plain ... and there is nothing but this same present moment in which is layered the plain's entire history. The description of 
that "lusty," thriving and widespread plain gives it a spatial plenitude, and simultaneously, its layering of past and present inhabitants gives it a temporal plenitude, as its past and present inhabitants are comfortably and imperceptibly layered within its constant present moment. The flow of the river Po is here replaced with, or transformed into, the layering of past and present and the imperceptible, paradoxical, but real, historical distance between the two. The tale soon develops the theme of the distinction but also relationship between the past and the present Italy and Italian people, through Walter's people's concern over the continuity of their identity from the past into the future, and their request that Walter marry to secure his heir and their continuity. It is through this theme that the Clerk's Tale can be found closely relevant to the Clerk's concern with Petrarch in his Prologue, since Petrarch himself was concerned with the revival of the old Italy and was celebrating the rebirth of its Classical age. Petrarch, however, emphasized Classical Italy as opposed to the medieval one, and celebrated the Renaissance of the Classical age at the expense of debunking the centuries in between and considering them no more than the dark "Middle Ages" in between the two golden ones.

Through the Clerk's voice in the tale's prologue, Chaucer associates the river of time running through Italy with two opposites: origins and identity on the one hand, versus temporal flow, deferral and the unknown future, on the other. Petrarch was interested in origins, and wanted to preserve and renew Italy's Classical origin and to bring it into a new birth. But Petrarch also deposited a vast and dark gap of seeming nothingness between the two, which came later to be known as "medium aevum" or the "Middle Ages," as though these centuries had no identity in their own right, beyond their 
function as a nameless passage between the two golden ages. ${ }^{\mathbf{3 6}}$ William Rossiter $^{\mathbf{3 7}}$ drawing on Robert Edwards, ${ }^{38}$ and through him on Morton Bloomfield ${ }^{\mathbf{3 9}}$ and A. J. Minnis, ${ }^{40}$ in addition to Lee Patterson, ${ }^{41}$ describes Petrarch's division of history as one between "the classical past, the inglorious present, and a possibly reinvigorated future, based upon the recovery of the past." ${ }^{, 42}$ Rossiter agrees with Edwards in the latter's argument that Chaucer's example demonstrates that "historical consciousness"" did not begin only in the Renaissance, and that conceptions of " the classical past as a conceptual whole" were already present during the Late Middle Ages. Chaucer's perception of history, like Petrarch's, differed from the traditional "correlation of pagan and scriptural historicism," based on Sts. Jerome's and Augustine's views. ${ }^{43}$ Rossiter refers to Bloomfield's description of Chaucer as having a similarly " "new heightened attention toward past, present and future,"” and to Edward's argument that Chaucer had a "sense of the "pastness of the past.",44 He disagress with Wallace that "that Chaucer was belittling

\footnotetext{
36 The classic article on Petrarch's ideas of the 'dark ages' is Theodore E. Mommsen, "Petrarch's Conception of the 'Dark Ages'," Speculum, 17.2 (Apr., 1942): 226-242, reprinted in Medieval and Renaissance Studies, ed., Eugene F. Rice, Jr. (Ithaca, NY: Cornell Univ. Pres, 1959). Jaque Le Goff states that: "Between storia antica and storia nova, Petrarch places the dark ages (tenebras), which extend from the fall of the Roman empire to his own time" in History and Memory, trans. Steven Rendall and Elizabeth Claman (New York and Oxford: Columbia Univ. Press, 1992), 29. For a more recent history of the conception of the "Middle" or "Dark Ages," see Eric G. Stanley, "The Early Middle Ages - The Dark Ages - The Heroic Age of England and in English," The Middle Ages After the Middle Ages in the English-speaking World, eds. Marie-Françoise Alamichel and Derek Brewer (Cambridge: D. S. Brewer, 1997), 43-78. Information and bibliographical references on this topic are available in Giuseppe Mazzotta, The Worlds of Petrarch (Duke University Press, Oct 19, 1993), 194-5.

37 William T. Rossiter, Chaucer and Petrarch (Cambridge: D. S. Brewer, 2010), 54.

38 R. Edwards, Chaucer and Boccaccio: Antiquity and Modernity (Basingstoke, 2002), 23.

39 Morton W. Bloomfield, 'Chaucer's Sense of History', JEGP 51 (1952): 301-13.

40 Alastair J. Minnis, Chaucer and Pagan Antiquity (Cambridge, 1982) and also Minnis, "From Medieval to Renaissance? Chaucer's Position on Past Gentility," Proceedings of the British Academy 72 (1986): 205-46.

${ }^{41}$ Lee Patterson, Chaucer and the Subject of History (Madison, WI, 1991).

42 Rossiter, Chaucer and Petrarch, 54.

43 Ibid.

${ }^{44}$ Ibid.
} 
Petrarchan historicism" in the Monk's Tale, ${ }^{\mathbf{4 5}}$ and he agrees with Wallace's reviewer that "there 'may be more Of Petrarch in Chaucer than Wallace would have us believe'." 46

Chaucer is asking, how we can know that this rebirth is indeed a renewal of the same people and the same identity? What is it that ensures the continuity between the country and people of the "fadres olde" and all the present lands and people among whom the Po still seems to flow down the same path? The answer he gives is a defense of the "medium aevum," whose Christian faith Grizelda represents. The flow of time, in and of itself, even upon the same landscape, cannot ensure any identity between the people and lands of the present and those of the past. In a similar way descent by blood does not ensure the identity of Ancient Italy with the present one. The physical and sensible flow is no more capable of carrying the identity of a person, people or civilization than is Heraclitus' river.

The connection between Heraclitus' river of time and Walter's behavior is radically important to the meaning and structure of the tale. Walter represents time in his behavior. The people's request that he marry and secure them an heir and continuity of identity is more than a passing excuse for the story of Walter and Grizelda. It is at the heart of the matter. They are asking Walter to transform the formless flow of time into a grasped and ordered time by getting married. But, on what basis will Walter, whose life is flowing away, be able to transform time into a meaningful and ordered reality which can sustain the continuity of his and his people's identity? On what basis can any wife he chooses have a stable identity, can his union with her be more than equivocal, and can the child arising from this union be more than just a passing part of the same flow?

\footnotetext{
45 David Wallace, Chaucerian Polity: Absolutist Lineages and Associational Forms in England and Italy (Stanford, CA, 1997), 301-8.

46 Rossiter, Chaucer and Petrarch, 55, quoting Review of Wallace, Chaucerian Polity, in Review of English Studies, 46: 196 (1998), 497-9.
} 
Similarly, what is it that has the power to make "the day of weddyng" (246) any different from any other day within the flow of time? What would ensure that that day is a unique and lasting event, and a grasping of the time, as it is meant to be? When Grizelda is brought into his palace, she seems to be no more than an abjection, an aporia, within a shell of clothing. "Hir heris han they kembd" (379), and the external regalia with which she "fro foot to heed they clothed han al newe" (378) indicated her station, but not her. Walter had even prepared, for her, "gemmes set in gold and in asure,/ "Brooches and rynges" (254-55) and "othere ornamentes alle" (258) before she herself had any notion that she was the one chosen to fit them. Chaucer emphasizes that there is nothing to bind Grizelda in her individual particularity to any of these external signs supposed to mark the marquis" "wife" and the people's new marchioness. Walter had ordered her clothes to be made to "mesure" (256), though not by taking her measurements, but by taking those of "a mayde lyk to hir stature" (257). On the day of the wedding he "hath hir spoused with a ryng." Grizelda seems to be totally interchangeable with anyone else. Walter's marriage to an unknown figure inhabiting the identity of 'wife', 'marchioness', and 'mother' of his 'heir' does not have the power to ensure the continuity of the identity of the people of his county—-known as a 'march'— beyond such arbitrary and passing appearances as clothing, ceremony and palace ambiance. Both facts-first, Walter's insistence on secrecy over whom he has chosen for wife all the way until the wedding day, and second, the fact that he chooses someone unknown, and from a poor community living close to nature-emphasize the aporia-within-clothing effect.

Walter, though, seems to be aware that the continuity of identity and the transformation of time from a flux into an ordered whole, which his people desire, are no simple matter. If his behavior speaks for the flow of time, it proves to speak as well for 
its Saturnine quality. Chronos, who carries a scythe, is a fragmenter and an agent for disintegration, as Chaucer represents him in the Knight's Tale. But he also provides the initial and necessary part of the alchemical testing, or "assay[ing]" (1166) which ultimately leads to an indestructibly unified Philosopher's Stone. He provides the "dissolution" that is necessary before the "conjunction," can be realized, and the "separation" which George Ripley advises his initiate to perform not manually, as do the false multipliers, but philosophically. In his role as Chronos, Walter fits the fairy-tale figure of the "monster bridegroom" argument which some critics have held, as Larry Benson mentions in his notes to the Clerk's Tale. ${ }^{\mathbf{4 7}}$ In the Knight's Tale, the Saturnine Father Time takes responsibility for the arbitrariness that conditions people's lives and for all the misfortunes that befall them, and that cause their deaths. So does Walter as Chronos arbitrarily raise Grizelda to fortune, stripping her from her old lowly identity, and as arbitrarily bring her down to misfortune and strip her again of all the spatiotemporal effects that defined her high station, and so does he also cause the 'passing away' of her children $(K T, 1596-1611)$. Not only does Saturn slay people but also causes "The fallynge of the toures and of the walles" $(K T, 1606)$, a misfortune similar to that which Walter's people seek to avoid. Yet, paradoxically, it is in order "anon, to stynten strif and drede" (1592) and "remedie fynde" (1594) that Saturn effects all this temporal chaos, which is also "strife" among the elements, in Ancient Greek Philosophy. Saturn seeks to stint the strife and find a remedy "Al be it that it is agayn his kynde" (1593) to do so. Similarly, it is Walter's nature to allow time to flow, and it is against his natural tendency that he accept to remedy the situation for his people and allay their fears.

\footnotetext{
${ }^{47}$ Benson, Riverside Chaucer, 880.
} 
The people's desire for the preservation and continuity of their identity against the arbitrary and meaningless flow of time, radically deepens the importance of the language and imagery which associate Grizelda with Virgin Mary at the time of the Annunciation (288-294) and Incarnation. The image of the "oxes stalle" (207, 291-94) is Chaucer's own, not found in his sources. ${ }^{48}$ Grizelda represents inner identity, and the soul whose humility dissociates it from the material and sensibly defined sources of identity and whose faith provides it with a source of identity beyond time. Her faith roots her being in God and renders her an agent of the Incarnation. At the same time, her body is anchored at the center of nature, like the "body erect" in the Host's speech in $M L T, 11$. Once the people become better acquainted with her, they recognize her true identity, regardless of the external effects that define her as a marchioness. They come to believe "That she from hevene sent was, . . . / Peple to save and every wrong tamende" (440-41), a description which alludes to a "passage from the Apocryphal Gospels of the Infancy,"49 and which adds another suggestion of Grizelda as an agent of the Incarnation.

If Walter speaks for the flow of time and its effects and role, Grizelda speaks for the soul which faithfully guards its relationship with a divine origin beyond time. Her father's cottage in the midst of nature, makes her also attuned to the order of nature in which everything has a right time. In the later rebirth of their marriage after her trials, Grizelda is recognized in herself and is, both to the people and to Walter, no longer an empty aporia within a shell of clothing which can be equally filled by any other. Chaucer presents Grizelda's faith--the Christian doctrine represented also by the Clerk-and the Incarnation, as the heart of those "Middle Ages" on the basis of which identity can be preserved, and Ancient Italy can be reborn into a new, more refined and golden

\footnotetext{
${ }^{48}$ Ibid., 881.

${ }^{49}$ Ibid., 882.
} 
age. The living connection with God in Grizelda's faith, and her living union with nature in her humility, renders her a union of the natural with the divine, just as the alchemical marriage should be. She becomes like the mysterious invisible depths of "Mount Vesulus" the womb from which the Po originates, and out of which it flows. As her agency for the Incarnation ensures the rebirth of her marriage to Walter, the continuity which Walter's people desire, and the identity which Walter's heir will carry into the future, so the agency of the Christian faith of the Middle Ages ensures Italy's connection with her divine origin. Through this connection she can keep her identity from the Classical past into the new Classical future Petrarch had hailed. Significantly, the Clerk refers to Petrarch as "deed, and nayled in his cheste, / I preye to God so yeve his soule reste" (29-30) and immediately follows this with mention of Petrarch as Italy's Poet Laureate (31). Both references allude to the death and resurrection of Christ. The image of being "nailed" is a conventional description of Christ on the cross, and it was on Easter Sunday that Petrarch was crowned Poet Laureate in $1341 .{ }^{\mathbf{5 0}}$ This, however, is not to miss the connection at the same time, of poetry with immortality. Chaucer, through his retelling of Petrarch's own retelling of the tale of Grizelda, reverses Petrarch's privileging of the Renaissance over the Middle Ages, and gives the latter the credit for connecting the past to the present and carrying the people of Italy's identity through time, and even Petrarch's own through death and into the Resurrection.

Unless we factor in Chaucer's medieval concern with the problem of the relativity of time, we would not be able to recognize the radical depth of Chaucer's project in this tale, and the fact that this tale is his reply to Petrarch's celebrating the rebirth of Classical

\footnotetext{
${ }^{50}$ Ibid., p. 879.
} 
Italy at the expense of debunking those ages he christened the "Middle Ages" which contain the very womb through which the new Italy is being born.

Grizelda's tale is one of breaking from the false identity which is a culturally, socio-politically and spatio-temporally conditioned one, in order to penetrate to a divine source of identity. She has been tested and found to be pure gold, a Philosopher's Stone which heals others around it, and turns them too into philosopher's stones as well. At the closing of his tale, the Clerk implies that Grizelda had been tested and proven as gold when he compares her with today's women who when "put to swiche assayes" (1166),

The gold of hem hath now so badde alayes With bras, that thogh the coyne be fair at eye, It wolde rather breste atwo than plye. (1167-69)

The gold into which Grizelda has been reborn is also the gold into which Petrarch wishes his Italy to be reborn. Through Grizelda's- the soul's-rootedness in God, Walter's county is renewed in the same way as the alchemical stone is purified and resurrected. Walter and Grizelda's marriage is one of Time with Eternity, and the human with the divine. This union is itself a Philosopher's Stone which Arnold of Villanova's Rosarium Philosophorum, a foundational medieval alchemical text, represented as the Resurrected Christ, but resurrected on Earth, and thus in fact Incarnated as well. ${ }^{\mathbf{5 1}}$ In more orthodox terms, it is a 'Supreme Allegory', formed in the likeness of the Incarnate Christ who is the divine Exemplar of this union. The child of this marriage, like that of the Phoenix, is the Philosopher's Stone as well, and the embodiment of this union into a physically single person. Walter tells Grizelda that their son "faithfully/ Shal be myn heir, as I have ay purposed; / Thou bare hym in thy body trewely" (1066-68). Grizelda has given birth to a true heir with an unambiguous identity because her body, in which she "bare hym ...

\footnotetext{
${ }^{51}$ See my discussion of Arnaldus of Villanova's Rosarium on pp. 253-54.
} 
trewely," is no mere "primal matter." It is a fully created, fully particular, bounded, formed and unique entity, inseparable from the unique and uninterchageable person Grizelda. It is even a sanctified entity that has been transformed by the Incarnation, and is a member of the Eucharistic body of Christ. While Chaucer, the Late Medieval poet, emphasized the formlessness of time and the degradation of the human condition in this world, his pronouncement of abjection against the sensible world is strictly limited, and in fact based on his faith in the sanctity of the body and the vital importance of the body in the journey of redemption.

Attention, therefore, to the medieval author's philosophical concerns, and in the case of this study, his fundamental concern with the ancient problem of the infinity and relativity of time, can unveil meanings and structures that have hitherto eluded us. Attention to Chaucer's prominent use of Heraclitus' metaphor of the river of time unveils the fundamental allegorical structure of the Clerk's Tale. It also suggests the formal centrality to that structure, of his allusion to the Incarnation $(207,291-94)$ as it claims for the tale the nature of a healing 'triacle' $(M L T, 479)$. Most interestingly, it unveiled Chuacer's encoding into the tale of a reply to Petrarch's debunking of the "Middle Ages."

\section{Ripley, Norton and The Canon Yeoman's Tale}

Chapter Four discusses a quotation Thomas Norton's Ordinal of Alchemy (III, 1158-1165) makes of a passage from Chaucer's Canon Yeoman's Tale. Of that entire tale, Norton chooses to quote the passage in which Chaucer uses his well-known phrase "ignotum per ignocius" or "an unknown by another unknown" $(C Y T, 1457)$ to describe the deferral of meaning in the language of alchemy. In this passage Chaucer has Plato openly explain that this deferral is deliberately meant to hide the secret wisdom and show it only to the initiated: "The philosophres sworn were everychoon / That they sholden 
discovere it unto noon, / . . " (1463-64). The way George Ripley and Thomas Norton adopt and use Chaucer's satire of alchemists and his theme of deferral, indicates that in their perception Chaucer did not intend "ignotum per ignocius" as a description of human existence or of language in the absolute. Rather, they understood Chaucer to frame this human condition within limits. The condition of deferral fully governed the lives of those who were immersed in the sensible mode of perception, and would not lift their heads above it. Although their understanding of Chaucer, in itself, does not necessarily entail Chaucer's own understanding, their reception of him is not to be ignored. They were both highly educated, in addition to being alchemical authorities. A close analysis of their work, as we shall see in the following chapters, reveals sharp minds and keen intelligence far more than the lowly vernacular of their verse discloses at first. They certainly knew the alchemical tradition more than the Chaucer scholar today can know unless she or he has spent years in the study of this tradition. There is no reason to doubt their understanding, in general, of the way Chaucer fitted into the alchemical tradition.

In fact Chaucer was well in keeping with the alchemical tradition that emerges from the analysis this dissertation provides of both these alchemical poets' texts. In his Ordinal Norton refers to the alchemical masters' deliberate veiling of their texts more than once. In the "Prohemium" he describes them as darkening their language through the use of "poyses, parabols, \& in methaphoris alle-so." This hiding of their wisdom behind dark veils brings "peyne and wo" not merely to the lay reader, but to scholars. Norton's remark suggests that even the usual education might not, in itself, be sufficient in guiding them to unveil the darkness.

Al mastirs which write of pis soleyne werke, Thei made theire bokis to many men ful derk, In poyses, parabols, \& in methaphoris alle-so, which to scolers causith peyne and wo; 
For whate herof thei wrote with theire penne, Theire clowdy causis dullid many men.

Fro lay-men fro clerkis \& so fro euery man, Thei hidde this arte that no man fynde it can Bi theire bokis, thofe thei shew reson fayre, wherby moche peple be broght in-to despeyre. (Proh., 61-66; 71-76)

As we shall see, the genuine alchemical "artist" and "philosopher" must be spiritually pure as well, and must pray for Grace, since without divine inspiration, he will not be able to attain the Philosopher's Stone. Those who are not spiritually aware-who, in other words, are not able to lift up their heads above the limits of the sensible worldwill not be aware even of the possible location of the kernel of meaning in the text. As such they have no chance of grasping the way in which the language of alchemy inscribes its meaning into the text, since that way involves a mode of meaning beyond the sensible. This point is so central to the alchemical tradition that the very first two lines with which Norton opens his Ordinal state:

Liber iste clericis monstrat scientiam, Liber sed laicis auget insciciam; (Pref. 1-2).

(THIS Book shews to the initiated knowledge, but intensifies the ignorance of the vulgar ${ }^{\mathbf{5 2}}$

As elitist as this may sound, or even be, Norton's "vulgar" points to those who do not look beyond partial and material goods. The alchemist's intentionality must be lifted towards divine truth, since the hidden knowledge the alchemist seeks belongs to God. Otherwise, his quest for the hidden meaning, like the rest of his quest for the objects of his desire, will always be elusive. Like Norton, George Ripley, his mentor, similarly

\footnotetext{
${ }^{52}$ This translation is by Arthur Edward Waite, ed. and tr., The Hermetic Museum Restored and Enlarged; Most Faithfully Instructing All Disciples of the Sopho-Spagyric Art How That Greatest and Truest Medicine of the Philospopher's Stone May be Found and Held. Now First Done into English from the Latin Original Published at Frankfort in the Year 1678 Containing Twenty-two most celebrated Chemical Tracts Vol. II (London: James Elliott and Co., 1893), 3-4.
} 
insisted that the spiritually 'ignorant' should stay away from alchemy, since they would only get impoverished by it.

With regard to George Ripley (1415-1490), it is worth pausing for a moment. The coincidence contributing to his relation to Chaucer is itself the stuff of tales. Not only did his Compound of Alchemy carry deep themes and strong echoes from Chaucer's Canon Yeoman's Tale. He himself also carried resonance from that tale in his own person. In remarkable and unlikely addition to his poetic imitation of Chaucer, he was himself, both a canon and an alchemist. He was a prolific writer of alchemical texts, and even carried out alchemical experiments at the Augustinian priory in Bridlington, Yorkshire, where he was a canon regular. He was highly travelled, studied at universities in Italy, was a close favorite at the Vatican, and travelled in the continent in search of alchemical wisdom, which he claims to have discovered it in Italy. ${ }^{\mathbf{5 3}}$ At the same time, like Chaucer, he was a poet.

Rather than defending himself or his station against Chaucer's portrait of corrupt Canon-Alchemists, real or fictional, Ripley joins Chaucer in satirizing the imposters, the dupes and the "lewed" alchemical hopefuls, both secular and religious, whose desires are constantly deferred. He imitates Chaucer's satire of the "Canon" and the duped monk, and borrows Chaucer's descriptive ideas and language in this satire:

22. Their clothes be baudy and worne thread bare, Men may them smell for multipliers where they goe, To file their fingers with corosives they doo not spare, Their eyes be bleard, their cheekes leane and blowe, And thus for had I wist they suffer losse and woe:

$\ldots(\mathrm{V}, 22.1-5)$

Like Chaucer's Canon whose appearance is "sluttish," $(C Y T, 366)$ and garment "al baudy and totore" (CYT 365), the clothes of Ripley's alchemists are "baudy and worne thread

\footnotetext{
${ }^{53}$ Linden, George Ripley's Compound of Alchemy, vii-viii, x n. 7, xii.
} 
bare." Their "eyes be bleard" also, as in the Yeoman's complaint: "of my swynk yet blered is myn ye" $(C Y T, 730)$. Also like Chaucer's Canon and his Yeoman, their faces too have lost their hue. There are many other similarities with Chaucer in Ripley's long description of the "multipliers" who call themselves "philosophers," such as in the crooked ways these alchemists try to win over customers.

Ripley does not perceive the intentions of Chaucer's satire to touch him in his capacity as alchemist, or even as Canon-alchemist. On the contrary, he empathizes with Chaucer's language, and at the same time believes that he himself belongs to those who are chosen by God. Chaucer had said, in the concluding section where the Yeoman's voice seems to blend with his, that "For unto Crist it [the stone] is so lief and deere / That he wol nat that it discovered bee, / But where it liketh to his deitee / Men for t' enspire, . . ."(1466-70). Ripley similarly reiterates in his Compound the genuine alchemist's vital reliance on God's will and inspiration: "Therefore if God vouchsafe thee to inspire, / To know the truth, and fansies to eschew / Like unto thee in riches shall be but few (V, 20.57). He also claims that God has inspired him and granted him the perfect knowledge: "Yet as God would, evermore blessed be hee, / At the last I came to the knowledge thereof perfite" (IX, 9.1.5-6). These failed alchemists and false philosophers who will never attain their desire, are ignorant since they only understand things sensibly, and have no spiritual perception. Ripley presents them working "after their fantasie" and dividing things "manually," when they should, as we shall see in the argument below, divide things into their ontological parts:

21. But many men be moov'd to worke after their fantasie, In many subjects in which be tinctures gay: Both white and red divided manually To sight, but in the fire they flye away: Such breake pottes and glasses day by day, Enpoysoning themselves and loosing their sights, 
With odours, smoakes, and watching up by nights. (V, 20.5-21.7)

Ripley emphasizes the materiality of their work, and the clutter of sensible images, as they "breake pottes and glasses day by day." Ripley has reason to believe that this is what Chaucer also meant in his Canon Yeoman's Tale. Thomas Norton, believed to have been Ripley's student in the alchemical art, also attributes the failure of the common alchemical hopefuls, and the deferral of their Stone, to their limitation in the sensible mode of perception. His description of them as unstable "botirflyes" who "wander and passe" (Ordinal, V, 12719) ${ }^{\mathbf{5 4}}$ is discussed at length in the chapter dedicated to Norton's Ordinal. In the Concluding section Chaucer, through his joint voice with the Yeomanor, perhaps more precisely, the universalized voice at the end-ascribes the failure of the materialistic alchemists to thier blindness:

"Ye been as boold as is Bayard the blynde, That blondreth forth, and peril casteth noon" $\mathrm{He}$ is as boold to renne agayn a stoon As for to goon bisides in the weye.

So faren ye that multiplie, I seye.

If that youre eyen kan nat seen aright, Looke that youre mynde lakke noght his sight. For though ye looken never so brode and stare, Ye shul nothyng wynne on that chaffare, .... (CYT, 1413-21)

Significantly, Chaucer advises the would-be "alchemist" to excercise spiritual vision: If with your bodily eyes you kan nat seen aright," make sure that "youre mynde lakke noght his sight." This is a very powerful message. So is the image Chaucer gives of the physicality of the Bayard-blind alchemists when Chaucer's verse performs a Petrarchan reversal which turns the reader from 'looking' with his inner eyes for the mystical referent of alchemical truth — the "root" which every alchemist and initate reader seeks in his intentionality—to stepping out and looking' at the Bayard-blind alchemist's face from

\footnotetext{
${ }^{54}$ John Reidy, ed., Thomas Norton's Ordinal of Alchemy, 84-85.
} 
the outside. From the outside, the reader sees the blind physicality of that alchemist's bodily eyes which "looken never so brode and stare" as he blindly searches among sensible things for the stone's divine secrets.

Chaucer's attribution of the ignorant "philosphres" failure, to their confinement within the sensible mode of perception, and thus to their inability to shape their minds into the form of an Allegory, is not his own invention. In the English of an eighteenthcentury translation of his "Rosarie," "Arnold of the Newe Toun" (Arnold of Villanova, 1235-1313), states,: "Whosoever would come to the knowledge of this Art and is not a Philosopher will prove a fool, because this Science is only of the Secrets of Philosophers." ${ }^{, 55}$ Chaucer reiterates this speech in the conclusion of the tale. The pronoun "he" in line 1441 refers to "Arnold of the Newe Toun":

And therfore, seyde he, - taak heede to my sawe Lat no man bisye hym this art for to seche, But if that he th' entencioun and speche Of philosophres understonde kan; And if he do, he is a lewed man. (CYT, 1441-45)

Chaucer was in perfect keeping with the tradition of alchemical literature when he reiterated this warning. He was not satirizing or warning against the entire tradition. What he was satirizing and warning against is the ignorance of mistaking sensible truth for spiritual truth, as well as the limitation of one's vision to partial and material goods. Ripley and Norton knew this. They were also not blind to the emphasis Chaucer places on hermeneutics when he specifically singles out the ability to understand the language

\footnotetext{
${ }^{55}$ I have used Adam McLean's edition of the $18^{\text {th }}$ c. translation. Arnold of Villanova, The Rosary of the Philosphers, ed. Adam McLean, The Alchemy Website, nd., np., http://www.alchemywebsite.com/rosary0.html, accessed 30 Mar., 2014, Part 1. McLean cites his source as the 18th century English translation of the Rosarium in MS Ferguson 210, which in turn was based on part II of De Alchemia Opuscula complura veterum philosophorum... (Frankfurt, 1550). A facsimile of the Latine original of Frankfurt /M.1550 is available as Joachim Telle, ed., Rosarium Philosophurum Ein alchemisches Florigeluium des Spatmittelalters: Faksimile der illustrierten Erstausgabe Frankfurt 1550 (Weinheim, Germany: VCH, 1992).
} 
of alchemy and its "entencioun" (1443), as the determinant whether or not one should venture into alchemy.

Both Ripley and Norton also share with Chaucer the central role they give to death in the journey of alchemical transformation and redemption. This emphasis on death is also found in previous alchemical literature. Towards the end of the process of the sages' textual unfolding of the Stone's constitution that the Rosarium Philosophrum represents, they recoup some of the wisdom that "this little book," meant to teach. "Albertus" (Magnus), states: "Unless the soul shall come forth from the body and shall ascend upward into heaven, you shall profit nothing in this art." 57 If the alchemist is to rise above the condition of deferral, his soul must leave his body, just as in Chaucer's advice, if your eyes are blind, which ironically also refers to the blindness of everyone's bodily eyes, "Looke that youre mynde lakke noght his sight." The mind must leave the bodily eyes, before it can return to them and produce a new and indestructible Stone which unifies the sensible with the spiritual. Chaucer's comment, also, that "the dragon, doutelees, / Ne dyeth nat, but if that he be slayn / With his brother" (1435-37), similarly derives from the Rosarium. In the first part "Geber" says: "the Dragon dieth not but with his brother and sister." The dragon, which is usually the prima materia, itself contains the seeds which carry the Trinitarian form according to which the dragon will be differentiated into male soul, which is also sulphur, and female body, which is also mercury. They will be united by the "spirit" which comes from beyond them, and which is usually identified with the acid ("water") in which the male and female are dissolved together. If we are to make any sense of the language of alchemy, it is important to

\footnotetext{
${ }^{56}$ One wonders whether this echo in the Rosarium, antecedent to the similar expression at the end of Troilus and Criseyde, was in Chaucer's memory at the time he composed that tale, since in the alchemical textual tradition the "book" is a readerly and hermeneutic enactment of the stages of transformation and self-constitution into an incorruptible entity.

${ }^{57}$ Arnold of Villanova, The Rosary of the Philosphers, Part 5.
} 
remember that Mercury in his different 'names' and aspects is both the whole and the parts, while at the same time these parts retain their distinction and identity. It is also both the beginning and the end. Unfortunately, an analysis of the esoteric and complex significance of the "killing" of the sulphur (associated with fire) and the mercury (associated with water) in its context in the Rosarium and the way it may be connected with Chaucer's tale, would involve an analysis of a large part of this "little book" and its textual connections, and must remain outside the limits of this study. But Chaucer's mention of the killing of sulphur and mercury brings the reader's attention to the centrality of the event of death for the formation of a Philosopher's Stone whose ontological and epistemological parts are indestructibly united even as each maintains its distinction from the other.

Both Ripley and Norton use a strategically located word which frequently occurs in the Canon Yeoman's Tale, and which refers to the deepest balance-point-a sort of synapse - in the cycle of life and death, where the divine will and power from beyond nature intervenes and turns death into life, and where the natural meets the divine from within the utmost depths of its materiality. This is the word "privitie" and its variations.

The passage through death indicates the Stone's experience of its limits, and contact with God. Through this enigmatic contact it receives wisdom, healing and renewal. In the narrative unfolding of the alchemical paradigm, the stone must first be destroyed, decomposed, and 'regressed' to its prima materia, thus becoming part of the undifferentiated primal chaos universally underlying everything in nature. In the depths of the prima materia, once the decomposition is complete, the stone discovers the blueprint of the divine act of Creation, the traces or "seeds" which God had left there. It is the equivalent of Platonic pre-lapsarian memory. The prima materia into which the stone 
"dies" becomes a boundary, an enigmatic location between death and life, where the stone meets the divine act of creation, the Prime Mover who creates through his Word, and pulls new life out of darkness. In short, the regressed stone discovers the Word itself, encapsulated in the seeds of the prima materia, and through it he receives new life. Christ is himself the "root" of alchemical transmutation, as well as the eternal form it imitates temporally in its transformation. In the Canon Yeoman's Tale, this "root"- or secret power-at the balance-point of the synapse between death and life, where man meets God-is a deep and divine "privitie." This "privitie" is up to Christ to disclose, and cannot be taken by force.

The contexts in which the word "privitie" occurs in Ripley's Compound indicates its identity as the secret "root" of alchemical wisdom. In the Prologue, Ripley instructs that his initiate always begin his operation with God: "with God looke thou beginne" if he is going to attain the "knowledge of our great privitie":

Therefore with God looke thou beginne, That he by grace may dwell with thee, So shalt thou best to wisdome winne; And knowledge of our great privitie: .... (Prol. 12.1-4)

This knowledge, in other words, is not the sort that one can attain in the natural mode. It is divine and one must receive it from God. This "privitie," therefore, is knowledge which God shares with man. As such it is a meeting point between the two, and it is a "privitie" that primarily belongs to God, and that He will choose to reveal to man. The stone undergoes death in each one of the three major stages of its transmutation. Ripley refers to "privitie" again in the second phase at the beginning of the Fifth Gate of "Putrifaction." He refers to it as "The privitie of our putrifying" (V, 2.6). He thus locates "privitie" at the depths of the Stone's fragmentation and death. In 
this gate of "Putrifaction" the male and female parts of the stone have been 'married' and will now "die" together as one body. Ripley refers to the scriptural parable of the grain of wheat that must putrifie and die before it can sprout into new life: "Sith Christ doth witnes, without the graine of wheate / Dye in the ground, encrease maist thou none get" (II, 1.6-7). He then raises one of those flags which hint at the reader that he must interpret. He warns his reader that unless he understands the "privitie of our putrifying" his labor will be "frustrate":

That thy labor therefore be not frustrate, The privitie of our putrifying well understand, Or ever thou take this worke in hand. $(\mathrm{V}, 3.4-5)$

The "privitie" is the secret knowledge that is crucial to the success of the operation, and it is located at the point of death and regeneration. At the same time Ripley esoterically slips in the idea that the stone - "our Compound"- is now a union, or "division of three things." In other words, at this balance-point between death and regeneration, something has been added to the stone from outside itself:

3. And Putrifaction may thus defined bee After Philosophers sayings, to be of bodies the sleying; And in our Compound a division of things three, The killed bodies into corruption foorth leading, And after unto regeneration them abling, For things being in the earth, without doubt Be engendred of rotation of the heavens about. ( $\mathrm{V}, 1.5-3.7)$

It is not exactly clear what lines 6 and 7 of stanza three are meant to explain. Is the "rotation of the heavens about," meant to explain the death and regeneration, or is it perhaps meant to explain the third element that has been clandestinely inserted. A scholar with chemical knowledge might find in this a hint to the alchemist to add a certain chemical ingredient. Nevertheless, the fact is that between death and regeneration, a third element or actant has been added, and the stone is now a unity of three parts, thus 
formed in the Trinitarian likeness of God. The third element is the Holy Spirit through Whom man and wife are united in marriage. In its triadic structure the stone has also become united with Christ, God's Word, who also is the image of the Trinity and the Exemplar from whom we derive this likeness. In his "Epistle to King Edward the 4," Ripley refers directly to God's "privitie." He asks of King Edward IV an oath of secrecy if he were to disclose to him the hidden knowledge, "Least I to me the wrath of God procure, / For such revealing of his great gift and privitie" ("Epistle," 6.7-8). The hidden privitie, therefore, that he would be revealing, is God's very own.

Chaucer also uses the word "privitie" in connection with Christ, and the liminal meeting point between man and God. In the concluding part of the Canon Yeoman's Tale Chaucer blends his voice with the Yeoman's and Plato's - and the reader's-in a concluding word of wisdom, a theoria that arises from the unified intentionaly of these voices. This voice of wisdom advises the pilgrims and the reader not to try to obtain this "privee stoon" (1452) by force, guile or cunning as the alchemist in the second part was trying to do, and to leave it "unto Crist" (1467) who will only "discove[r]" it "where it liketh to his deitee/ Men for t'enspire ... (1467-70). Through these words Chaucer brings the reader's attention to the agency of free will, and to divine Grace as the one that provides the mystical key to the redemptive alchemical operation.

Chaucer uses various forms of the word "pryvetee" eight times in the Canon Yeoman's Tale. In the second, or 'middle', part which comprises the Canon Yeoman's fictional tale proper, he uses this word ironically, to describe the privity within the deceitful alchemist's own mind as he hides his manipulation of the material of the stone, to create the false appearance of a successful transmutation. One instance occurs in line 1178, where the Canon-alchemist is slipping a piece of coal that secretly carries the silver 
filings craftily hidden within it, into the pile of coals "above the crosselet [crucible]" (1153). Another instance occurs in line 1323, at which point the deceitful Canonalchemist "pryvely" (1177) exchanges the piece of copper supposed to be the base matter of his stone, with the melted piece of silver supposed to be the transmuted copper. Chaucer's use of the same word for "pryvetee" that belongs to God-and is "unto Crist . .. so lief and deere / That he wol nat that it discovered bee, / But where it liketh to his deitee" (1467-69) - powerfully accentuates the contrast between the appearance of transmutation that the false alchemist and artist is creating and the redemptive and creative privacy of the seed of His likeness which God has invisibly hidden in the raw material of nature, and thus the material of the stone. The base matter of nature that the alchemist is falsely manipulating implicitly takes on a Eucharistic significance, since it carries the seed of divine Wisdom within it. The Canon is comparable to an ignorant and false priest who handles the Eucharist and administers it to parishioners while he himself is blind to the deep sanctity of what he is handling.

The connection of the stone, the matter of nature, with the Eucharist was no mere poetic metaphor, since the traces of God were in the prima materia of nature. They were the Trinitarian "seeds" of God's Word, the likeness which God placed in every creature and which, ingrained in the creature's primal being, gave it the desire to seek Him and inspired it to grow into the form of this likeness. Christ, who is God's self-knowledge, is the divine Exemplar of this likeness. Through it God gives Himself to His creatures. A historical and perhaps amusing instance exemplifying the popularity of the idea of the Eucharistic presence in nature, is the reason which "Prinn, in his "Aurum Reginae" cites, for the patents King Henry VI gave ecclesiastics to produce alchemical gold. This was "that they were such good artists in transubstantiating bread and wine in the Eucharist, 
and therefore the more likely to be able to effect the transmutation of baser metals into better." 58

The irony which Chaucer creates in his double use of "pryvetee" brings into visibility a distance between the two "privetees" that is painfully stark and stunning. The contrast is powerful between the invisible seed of the divine presence, and as such, act of Creation, hidden within the natural material of the stone, and the false activity hidden within the privacy of the alchemist's mind as he ignorantly handles that stone in fraud and in total blindness to its sanctity. The Canon-alchemist creates a false appearance of that stone's power, without recognizing the real power inherent in it, or realizing that through purity he can truly unlock that power. The contrast between the alchemical operation as a donum dei and this same operation as one that the alchemist seeks to force out through cunning, Chaucer significantly presents as a contrast between an operation that is inspired and defended by Christ, and an operation that is conditioned by endless deferral:

For unto Crist it is so lief and deere That he wol nat that it discovered bee, But where it liketh to his deitee Men for $t^{\prime}$ enspire, and eek for to deffende Whom that hym liketh; lo, this is the ende. ....

For whoso maketh God his adversarie, As for to werken any thyng in contrarie Of his wil, certes, never shal he thryve, Thogh that he multiplie terme of his lyve. And there a poynt; for ended is my tale.

God sende every trewe man boote of his bale! (CYT, 1469-71, 1476-81)

Lines 1467 to 71 comprise a long sentence that runs through five lines without stopping, thus giving all the more weight to the expression that ends it: "lo, this is the ende." The word "ende" means both "goal" or "purpose" and at the same time the end of a process,

${ }^{58}$ Ibid. 
be that process the long sentence itself-which states the concluded truth of the alchemical process - or the tale as a whole, or the operation of alchemical transformation. This definitive "lo, this is the ende" gives finitude and form to the flow of the language and at the same time it gives Christ as the source of the operation. In doing so, it sharpens the contrast of this definitive end with the deferral which characterizes the "werk[e]" of the person who "maketh God his adversarie," and who works against "his wil" (1476-78). Such a person "never shal he thryve,/ Though that he multiplie terme of his lyve" (147879). The last two lines that end the entire tale in its three parts, likewise emphasize the end, as well as that fact that this is the end: "And there a poynt; for ended is my tale." By implication Chaucer is contrasting the fact of truly arriving at an end against the endless multiplication of the previous line. The reader who recognizes this deliberate contrast, will more easily notice also the connection that this universal voice of wisdom is making between deferral and its healing that comes from God. In that last line "God sende every trewe man boote of his bale," the bale implies the state of deferral, and the boote implies the divine intervention that occurs when Christ reveals his private knowledge to the alchemical pilgrim. Chaucer is unmistakably identifying the deferral that conditions the alchemist's work without God, with the same condition which characterizes narrative when it fails to grasp a divine sort of truth, a sort of truth beyond its own flow. He is also identifying the remedy, "boote," that he is asking God to send to "every trewe man" with the same remedy - divine inspiration - which gives shape to narrative time, and which makes it possible for the tale to be a unified whole, and an entity that carries divine Wisdom within it. 


\section{Chapter Two}

\section{Allegory and Allegoresis in Ripley's Compound}

Then heaven upon earth must be reiterate Untill the soule with the bodie be incorporate That earth become all that before was heaven, Which wil be done in Sublimations seaven.

(The Compound of Alchemy, VIII, 6.4-7)

[Allegoresis] recuperates the text through concealment of it.... To read the text as integumentum imposes a new temporal and causal order between reader and text. The act of reading is figured as that of unveiling the text, which suggests the necessary belatedness of interpretation; ....

(Rita Copeland and Stephen Melville, in

"Allegory and Allegoresis") $\mathbf{5 9}^{\mathbf{9}}$

The deep esoteric darkness of Ripley's (1415-1490) Compound of Alchemy (1471) must have been a major factor in the neglect it has suffered in the last four centuries, and for its consequent exclusion from the curricula of English literary studies. This chapter works in part towards giving the reader some of the tools he needs to "see in the dark." It works to make the Compound's artistic features available, and give it some of the appreciation it deserves as a literary, and not only alchemical or occult text. While the Compound does not boast the brilliance of those "Stones" written by the greatest authors of the fourteenth to sixteenth centuries, it nevertheless emerges as a truly valuable gem of English and Western European literature. Its direct concern with what it is that constitutes an indestructible entity can shed light on the fundamental concerns of $12^{\text {th }}$ to $15^{\text {th }}$ C. literature. Its definition of that entity "which of this world $\ldots$ is called the

\footnotetext{
${ }^{59}$ Rita Copeland and Stephen Melville, "Allegory and Allegoresis: Rhetoric and Hermeneutics," Exemplaria, 3 (1991): 159-87, 171.
} 
sement" (V.20.1), as a Philosopher's Stone, can enhance our as yet limited understanding of the nature of allegory. It presents the Philosopher's Stone not merely as a common personification, but as the personification of Allegory itself, and not merely as a referent to an "allos," but a substantial allegory in the sense that it is enacted by the characterthe "Stone"- and by the reader who becomes its living embodiment. A crucially important way in which the Compound leads to a deeper understanding of the architecture of "Allegory" is in the distinction it makes between allegory and the textual and temporal work to enclose or disclose it. "Allegory" is the "Philosopher's Stone," and is itself the object of its own interpretation and the intentional goal of the textual wrapping of meaning and the hermeneutical unwrapping of it.

This chapter is not concerned with the Compound's contradictions and shortcomings. These will be partly discussed in the next chapter. In this chapter I adopt "the suspension of disbelief" as a launching platform from which to approach Ripley's work on its own grounds, in its ideal intentionality, and argue for Ripley's deliberate, painstaking and comprehensive translation of the complex process of alchemical transmutation into a radically textual process, and consequently of his anchoring of the relatively isolated genre of alchemical literature into the general literary tradition of England and Western Europe. I analyze the way he textualizes the process of alchemical transmutation, and I foreground the relationship he sets up between "allegory" and "allegoresis." "Allegory," I argue, he personifies in the "Philosopher's Stone," that "kernel" to be discovered, which organically unites all epistemological modes into a simultaneous theoria or act of wisdom, and which does so ideally without violating the internal and individual integrity of these distinct modes. "Allegoresis," he embodies in the interpretive performance of his reader. He guides the reader through an openly 
aporetic text which asserts the gap between word and meaning, and which persistently reminds the reader to interpret. Ripley turns his reader into an allegorical interpreter, and transforms him into an alchemical pilgrim who is transmuted through the text- a text which persistently prods him to enact the operation of knowledge that leads to wisdom. I further argue that Ripley uses the aporia between text and 'meaning' to highlight the reader's intentional act of interpretation as the vehicle through which text and meaning are connected. In the gap between text and meaning, Ripley also locates the hidden referent of the reader's intentionality, namely the "root" and "privitie" he seeks.

It is important to add, however, that the Compound's literary value and its textualization of the alchemical operation do not rule out the presence of serious chemical information in the Compound. I do not presume to judge the chemical aspect or the possible practical information, especially given that Ripley, by his own admission in "Erronious Experiemnts," has indeed indulged — plausibly to a considerable extent, as it is generally believed - in practical alchemy. The extent of practical information can only be determined by scholars such as Lawrence Principe who have studied the chemical aspect of alchemy ${ }^{60}$ Ripley was highly regarded in the field of alchemy, and, according to Charles Mackay "was very rich, and allowed it to be believed that he could make gold out of iron." Mackay cites "Fuller, in his 'Worthies of England,' for the note that "a gentleman of good credit reported that, in his travels abroad, he saw a record in the island of Malta, which declared that Ripley gave yearly to the knights of that island, and of Rhodes, the enormous sum of one hundred thousand pounds sterling, to enable them to

60 For information of the chemical aspect of alchemy, see Lawrence M. Principe, The Secrets of Alchemy (Chicago: The University of Chicago Press, 2013). 
carry on the war against the Turks." ${ }^{, 61}$ In connection with these donations, one must consider, however, Ripley's close ties with the Vatican, and the question whether these recorded donations were connected with it.

Ripley's account of alchemical transformation was of no small influence. His travels in Europe, association with Italian alchemists and philosophers, his familiarity with and, probably, residence in the Vatican ${ }^{62}$ indicate a wide range of activity and acquaintances on his part. Mackay states that Ripley studied at universities in Italy for 20 years. ${ }^{63}$ Young disciples of alchemy, such as his student Thomas Norton, ${ }^{64}$ sought to learn from Ripley and later alchemists, such as Michael Maier and Michael Sendivogius, closely and eagerly studied and interpreted his treatises.

At the same time, however, the most outstanding part of Ripley's career was performed in his capacity as a "Philosopher" rather than as a practical alchemist. In the 1591 edition of his Compound of Alchemy, Raph Rabbards describes him as "the learned and rare Philosopher of our Nation," ${ }^{, 65}$ Early in the century, in 1404, which happens to be soon after the death of Chaucer, alchemy suffered a demise: Parliament passed an act "declaring the making of gold and silver to be felony," which Mackay states was due to the fear that alchemical gold may "furni[sh] boundless wealth to some designing tyrant." ${ }^{\mathbf{6 6}}$ Ripley flourished at a time when alchemy had re-emerged from its demise and he was part of the events that raised it to a golden age that it probably had not witnessed before. In 1445, King Henry VI granted patents and commissions "to several knights,

\footnotetext{
${ }^{61}$ Charles Mackay (1814-1889), Memoirs of Extraordinary Popular Delusions, 3 vols., vol. 3 (London: R. Bentley 1841), rpt. (Barnes and Noble Publishing, Inc., 2004), 106-107; cf. Stanton Linden, George Ripley's Compound of Alchemy, vii.

${ }^{62}$ Linden, George Ripley's Compound of Alchemy, p. x. See note 140 below.

${ }^{63}$ Charles Mackay, Memoirs of Extraordinary Popular Delusions, 50.

${ }^{64}$ Linden, George Ripley's Compound of Alchemy, xxxviii.

${ }^{65}$ Ibid. 1, cf. Jonathan Hughes, "Politics and the Occult at the Court of Edward IV," Princes and princely culture, 1450-1650, Volume 2, eds. Martin Gosman, Alasdair A. MacDonald, Arie Johan Vanderjagt (Leiden: Brill, 2005),p. 108.

${ }^{66}$ Charles Mackay, Memoirs of Extraordinary Popular Delusions, 49-50.
} 
citizens of London, chemists, monks, mass-priests, and others, to find out the philosopher's stone and elixir," to enable the King to pay his debts. ${ }^{67}$ Soon, alchemy came to be mined not only for its gold, but also for the power of its symbolism. Ripley's coining of golden speeches and symbols for the throne was at the center of this golden age of alchemy in England. He was closely involved in King Edward IV's 1461 accession to the throne and continued support afterwards. Jonathan Hughes describes Ripley's involvement in Edward IV's 1461 accession to the throne. In England Ripley was the philosophical and literary authority on whom Edward IV depended for constructing his image as a sun-king, a figure of renewal and of life-giving, as well as a descendant from Uther Pendragon, King Arthur's father. Hughes presents Ripley as “the Merlin behind the accession of Edward." Ripley helped present Edward as a new Arthur and who restored an aura of Merlin's magic back to England. ${ }^{68}$ All this must have contributed to making Ripley as well as his writings well known. Ripley's account of alchemical transformation was influential even during his lifetime and enjoyed wide circulation for at least the next two centuries. ${ }^{\mathbf{6 9}}$ Regardless, however, of the extent to which Ripley's Compound may contain secret alchemical recipes, my analysis does call assumptions of practical concerns in the Compound into serious question. The Compound is replete with indications that Ripley is steering his reader away from material transmutation in the laboratory.

As a shaping principle to my analysis of the relationship which Ripley sets up between allegory and allegoresis, I adopt Copeland and Melville's emphasis on the temporality of allegoresis and the implication of allegory in this temporality. Within this

\footnotetext{
${ }^{67}$ Ibid., 50.

${ }^{68}$ Hughes, "Politics and the Occult at the Court of Edward IV," pp. 97-128, pp. 110-113.

${ }^{69}$ Linden, George Ripley's Compound of Alchemy, xvi-20.
} 
context, I take the paradox of the rhetorical-hermeneutical circularity to be of crucial importance.

\section{The Compound's Hermeneutical role in the Alchemical Literary Tradition}

In the words of Copeland and Melville "we remain profoundly uncertain as to what constitutes an instance of it [allegory]. ${ }^{, 70}$ One way in which the Compound helps our understanding of allegory is in the crucial distinction it makes between the finished allegory-itself personified and embodied in the Philosopher's Stone-and the interpretive operation through which the reader comes to simultaneously understand and construct it. It alerts us to the fact that we have generally been confounding allegory with the textual process of interpreting it. The Compound's self-reflexive structure is based on a triad: a collaborative authorly-readerly, rhetorical-hermeneutical relationship, and a further relationship between these two together and the "Philosopher's Stone," their mutual visionary goal. Through this triadic structure, Ripley sets up a self-conscious relationship between allegory and allegoresis. Significantly, he treats allegory not in the common sense of an allegorical text whose sensible symbols must be interpreted into the literal truth they "really" mean to "say," but instead as a visionary goal of the process of meaning production, a sort of Stevensian "Supreme Fiction," or, more accurately, "Supreme Allegory," and he personifies this goal in the "Philosopher's Stone." The text which "speaks otherwise" he thinks of not as a given bubble of words, but as a performative process of interpretation - an allegoresis — which he persistently hints at his reader to perform through phrases such as "Take heede therefore, and understand me wittelie" (VII, 1.4). We must accept the darkness of his esoteric language as he meant it

\footnotetext{
${ }^{70}$ Copeland and Melville, “Allegory and Allegoresis, 179.
} 
to be understood: a multilayered veil of text, indeed, which one must peel off, to reach the hidden treasure, but also a veil of text which apophatically points at the act of its peeling as, itself, essentially constitutive of the "Stone." To peel is to compose, and as it is in Copeland's and Melville's elucidation of Fulgentius' and "Bernardus Sylvestris" understanding of allegoresis, "the mechanics of the text become part of the allegory, indeed are allegorized." Undoubtedly, in the Compound, "the locus of active intention has shifted from the author to the interpreter." ${ }^{, 72}$ We must, however, keep in mind that Ripley the author, presents himself, too, as a reader and interpreter of old texts, who is now re-wrapping the "Stone" hidden in the old texts, into a new and more perfected integumentum. As he tells his reader in the opening lines of his "Prologue" and the entire Compound: "These words of wisedome in minde doe thou beare/ Which of olde fathers be true in sentence" ("Prol., 1.3-4). Again, in Copeland and Melville's words, allegoresis "recuperates the text through concealment of it.",73

Ripley submits his product, the "seed," both kernel and shell, to the intentionality of his reader who will, in turn, perform a new event of knowledge, a new peeling and a new concealing, in search, and progressive recognition, of the ultimate goal of his intentionality. In the way the author's artificially designed text engages the reader, author and reader are bonded at a radically deep level, through the ultimate and ineffable figure of their intentionality, to which divine figure the intentionality of all human beings converges. This intentionality, Ripley would agree with Boethius, converges towards the supreme Good. In Chaucer's translation, Philosophie tells Boece: "For how so that men han diverse sentences and discordynge, algates men accorden alle in lovynge the eende of

\footnotetext{
${ }^{71}$ Ibid., p. 172.

${ }^{72}$ Ibid., p. 168.

${ }^{73}$ See the quotation from Copeland and Melville, "Allegory and Allegoresis, in the incipit to this chapter.
} 
good" (III, p.2, 122-25). She similarly argues, especially in the third Book in general, that the partial goods that one seeks, "whan thei ben gadred togidre [als] into o forme and into oon werkynge" (III, P.11, 16-30), towards God, the ultimate Good, they also gather together the person's being into a whole in relation to that single and ultimate goal which contains in itself all goals. Ripley would also agree with Aristotle that man's highest happiness lies in theoria, the power of redeemed, divine, and substantial knowledge in which all time converges to a point, and which Ripley, typical of medieval authors understood as "wisdom." This 'point' is at once ineffable and intimately knowable, and in it truth is one with being. While this point of convergence is divine and beyond this world, the seeking of it will recoil onto the seeker and transform him into the likeness of what he seeks-into a "Philosopher's Stone," the embodied and perfected likeness of God. The "Stone" includes all earthly purposes, and simultaneously transcends them. It cannot be formed without the seeker's turning towards the supreme Good.

The paradox of the rhetorical-hermeneutical circularity, which Copeland and Melville describe, is of immediate relevance to the relationship which Ripley sets up between allegory and allegoresis. It involves the authorial production of a textual integument to enclose the kernel of meaning, and the readerly act of peeling off this integumentum with the intention of grasping that kernel:

Allegorical interpretation thus proposes itself as the unveiling of the text. Yet, paradoxically, such an interpretation, aiming to "save" or recuperate the text, is itself an act of placing a veil over the visibilia of the text, a covering of the text so that it can be hermeneutically "recovered." Allegoresis, of course, creates the allegory which it proposes to explicate: by reading the text as allegory, allegoresis in effect supplies the integumentum or veil with which to cover the text; it recuperates the text through concealment of it. ${ }^{74}$

\footnotetext{
${ }^{74}$ Copeland and Melville, "Allegory and Allegoresis, p. 171.
} 
As based on the model of Fulgentius' and "Bernardus Silvestris"" own understanding of their interpretive projects, allegorical interpretation "proposes itself as the unveiling of the text." This however, is only one half of the bidirectional and circular operation as Copeland and Melville present it. While allegorical interpretation hermeneutically proceeds to uncover the hidden meaning, it rhetorically produces a new textual integument for that meaning. In their argument Copeland and Melville appropriately step back to judge the nature of these medieval exegetes' activities from a wider perspective beyond their own understanding of what they were doing. Neither Fulgentius nor "Bernardus" thought of themselves as "concealing" by "disclosing," or of their hermeneutical peeling — which moves towards the visionary wisdom hidden beneath the old integument—as a simultaneously rhetorical movement away from that hidden kernel, and back into a new integument. Ripley, in contrast, provides a model of allegoresis which does propose itself as a self-conscious enactment of this hermeneutical and rhetorical circle in its fullness. Ripley consciously recuperates the kernel of wisdom from the old texts of his alchemical fathers "through the concealment of it," and deliberately requires his reader to do the same.

Although Copeland and Melville's article approaches allegory and allegoresis within the framework of the medieval translatio imperii of old literature, Ripley's Compound takes us away from that framework, and treats allegory as a goal in its own right. To obtain that self-conscious personification of allegory, the Philosopher's Stone, is to obtain the secret of entitihood and indestructible truth. The Compound can tell us about the relationship Ripley has set up between the "Philosopher's Stone" as transcendent artifact and Supreme Allegory on the one hand, and allegoresis as the means through which his reader - as initiate in the alchemical art—can realize it, on the other hand. 
Copeland and Melville's valorization of allegoresis, however, is deeply helpful to our understanding of what Ripley was, in fact consciously, doing. In the opposite direction, the role Ripley gave allegoresis can also contribute our understanding of the questions raised by their article.

Copeland and Melville offer a convenient summary of it as the unveiling of "integumentum" or "involucrum." The concept of the integumentum, "crucial to medieval allegoresis," was advanced by the Chartrian school. Guillaume de Conches, "Bernardus Silvestris" to whom are attributed commentaries on Virgil and Martianus Capella, Adelard, and John of Garland all used it "to describe poetic fictions of ancient authors (especially pagan myths)." "Integumentum" usually indicated the textual veil "under which ancient poets and philosophers chose to conceal moral and scientific truths." Another similar term, "involucrum," suggested "a fictive disguise for truths." Virgil, according to "Bernardus" was a philosopher writing sub integumento. In his words:

"This is his mode of treatment: within an integument he [i.e., Virgil] describes what the human spirit does and experiences while it is placed for a time in the human body .... 'Integument' is a manner of presentation that veils the understanding of truth beneath a fabulous narration, whence it is also called a "wrapping'.,"76

Ripley uses a similar metaphor of mining the substance of the metals out of the womb of the earth. ${ }^{77}$ But he perceives his Compound to comprehend both opposite directions: "Bernardus" hermeneutical unwrapping which moved towards the hidden meaning, and Virgil's fictional and rhetorical wrapping which moved back away from it and towards

\footnotetext{
${ }^{75}$ Copeland and Melville, "Allegory and Allegoresis, 169-70.

${ }^{76}$ Ibid. The translation into English is Copeland and Melville's own, and their quoted passage is from Julian Ward Jones and Elizabeth Frances Jones, eds., The Commentary on the First Six Books of the Aeneid of Vergil Commonly Attributed to Bernardus Silvestris, (Lincoln: University of Nebraska Press, 1977), 3.9-15 (proem):

Modus agendi talis est: in integumento describit quid agat vel quid paciatur humanus spiritus in humano corpore temporaliter positus.... Integumentum est genus demostrationis [sic] sub fabulosa narratione veritatis involvens intellectum, unde etiam dicitur involucrum.

${ }^{77}$ See the quotation on $\mathrm{p} .128$ below.
} 
the integumentum. He collaborated with his reader to uncover "what the human spirit does and experiences," and at the same time to wrap it back up into a new text. Through this double action, the reader redeemed and reconstructed his own self.

Ripley's Compound of Alchemy (1471) was recognized as a classic of alchemical literature early in the history of its reception. Its numerous manuscripts indicate that it had a considerably large audience. ${ }^{78}$ It quickly became well known in England, and by the end of the sixteenth-century it had spread into continental Europe. Jennifer Rampling describes the various translations and publications of Ripley's work and the works attributed to him in the sixteenth-century, and the role that John Dee and Edward Kelly's interest in them played in their dissemination in Western and East-Central Europe. Ripley's works served as authoritative sources as well as means of connecting the rising alchemists with their "contemporary practitioners." 79 Edward Kelley was also fascinated by them, though his interest was mainly in Ripley's practical knowledge. ${ }^{\mathbf{8 0}}$ Its manuscripts continued to be copied even after the printed edition was produced by Ralph Rabbards in $1591,{ }^{\mathbf{8 1}}$ and his works abundantly copied. In 1649, in Cassellis, a Latin edition of his collected works was published as the Opera Omnia Chemica. ${ }^{\mathbf{8 2}}$ Ripley

\footnotetext{
78 Stanton Linden's edition of George Ripley's Compound of Alchemy, on which I rely in this study, is based on Ralph Rabbards' 1591 edition. Linden dates Ripley's Compound on the basis of Sloane MS 2598, ff.1-71 v, marked with the date "1471." Among seventy five items he consults, "to which Ripley's name is attached" he states in his introduction that there are "at least eight complete, or very nearly complete, versions of the Compound, the earliest of which-unusual in its precise dating-coincides closely with the time Ripley is thought to have completed his poem. If Sloane MS 2598, ff.1-71 v, is written in a secretary hand, dated 1471, and subscribed with a sigil that may be derived from Ripley's name (f. $71 \mathrm{~V}$ ) or that of the scribe. It follows closely the ordering of the various sections of the Compound used in later manuscript and printed versions (although the 1591 edition adds dedicatory sections that are omitted in the manuscripts); these major parts are the prologue, preface, twelve gates, i.e., the body of the poem (ending on f.64V), followed by the 'Recapitulation' and 'Erronious Experiments"' (Compound, p. xvii).

79 Jennifer M. Rampling, "John Dee and the alchemists: Practising [sic] and promoting English alchemy," Studies in History and Philosophy of Science in the Holy Roman Empire, 43 (2012): 498-508, 498.

80 Ibid., p. 501.

${ }^{81}$ Linden, George Ripley's Compound of Alchemy. xvi.

${ }^{82}$ Stanton J. Linden, "Expounding George Ripley: A Huntington Alchemical Manuscript," Huntington Library Quarterly, Vol. 61, No. 3/4 (1998): 411-428, p. 414.
} 
(1415-1490) was a prolific writer, ${ }^{83}$ "One of the clearest indications that his works were well known and respected in the two centuries following his death" Linden states, "is the assiduous listing of his works by early commentators and antiquarians. ${ }^{.84}$ In his sketch of a "typology and chronology of alchemical poetry," Didier Kahn gives major and exceptional credit among vernacular alchemical poetry, to Ripley's Compound as well as to his likely pupil's, Thomas Norton's, Ordinall of Alchemy. "In scope, these poems encompass all of the aspects of the great work: theory and practice, instructions on furnaces and vessels, or on substances to be avoided, and allegorical accounts intended to convey the most important secrets." ${ }^{85}$ Along with the German illustrated poem, Sol und Luna (ca 1400) - based on a section of the Rosarium Philosophorum which is in turn based on Ibn Umail's (also Ibn Umayl's) Epistola solis ad lunam crescentem $^{\mathbf{8 6}}$-he describes them as "standard-bearer[s] of a poetry capable of transmitting, in versified form, alchemical teachings considered to have real value." ${ }^{\circledR 7}$ Kahn mentions the Compound's alchemical comprehensiveness and size, as well as Ripley's framing of his alchemical text in the extended metaphor of the 'Philosophers' Castle', as factors in its importance in the history if alchemical literature. Its comprehensiveness is in fact important not only in the context of alchemical literature, but in the context of the nature of allegory and of the theory of art. Ripley thought of his 'work' as itself a Philosopher's Stone, and as such a microcosm. The operation that produces the Stone is one in which Nature, man and God collaborate. By dealing comprehensively with all parts and aspects of the alchemical operation, Ripley incorporated into his Stone the working of the entire

\footnotetext{
${ }^{83}$ See Jennifer M. Rampling, "The Catalogue of the Ripley Corpus: Alchemical Writings Attributed to George Ripley (d. ca. 1490)," Ambix 57 No. 2 (July, 2010): 125-201.

${ }^{84}$ Linden, George Ripley's Compound of Alchemy, xiv

${ }^{85}$ Didier Kahn, "Alchemical Poetry in Medieval and Early Modern Europe: A Preliminary Survey and Synthesis Part I, 249-74, 257.

${ }^{86}$ Ibid., 258.

${ }^{87}$ Ibid., 258.
} 
universe, and rendered it the product of divine action and not only human. The importance of the comprehensiveness of the stone will be further discussed in the context of Norton's Ordinal in the next two chapters.

The last mentioned feature, that of the castle extended metaphor, contributes directly to the Compound's literary textualization of the alchemical process. While "spiritual alchemy" has always been "philosophical" rather than practical, and has, more commonly than not, been gnostic, and highly concerned with knowledge and wisdom, Ripley's textualization is not only thorough and systematic, but is deeply self-reflexive, radically concerned with the nature of meaning production and the nature of human artifice as a product with an active presence in the world. These characteristics render the Compound not only a landmark in its own alchemical literary genre, but also, as mentioned above, a remarkable text in the context of poetics in general. It is of interest especially for literary critics and theorists. Its text, therefore must be brought to life, and its esoteric language made more accessible to the general literary critic.

The extended metaphor of the circular castle with which Ripley framed his poem, is one of the indications that he was concerned with anchoring the Compound in the general literary tradition and not only in the alchemical one. Urszula Szulakowska describes Ripley's circular "Castell," which is "round as any bell" (I, 1.5), and the journey around it in a way that helps highlight it as a metaphor for a self-enclosed universe, suspended in infinity. In gates two and ten, respectively "Solution," and "Exaltation," Szulakowska sees the suggested implication of a voyage by sea. "He speaks of 'turning the wheel' to take a course into distant corners of the earth. Thus, he 
visualises the alchemist as a helmsman on a ship." ${ }^{88}$ Her description, including her calling attention to the fact that the entry of each gate is from the outside, since the Castle's gates stand in its outer circumference, all contribute to the effect of the worldthe Castle — surrounded by nothing, itself inclusive of the process by which it comes into being. Whether or not we think of it as a sea, whatever surrounds the "Castell," is imageless. Ripley speaks of entering each gate, but he never tells us where we are entering from. We must enter it from a virtual space within ourselves. The distant "corners" of the earth he speaks of are, in an inverted sense, part of the castle which 'squares the circle. ${ }^{89}$ They involve a sort of inversion similar to Dante's when he reaches the upper circles of heaven and discovers that while he had thought he was travelling outwards, into widening circles towards God, he was really traveling inward, and God was at the center.

In the metaphor of the mine discussed below, ${ }^{90}$ ("Erroneous Experiments," 13.1 14.4), Ripley gives his alchemical reader the role of mining the metallic substances hidden in the bowels of the earth out of hiddenness. The indications are that Ripley seeks to give his "Castell," which is the "myne" that hides his kernel, and by implication his

\footnotetext{
${ }^{88}$ Urszula Szulakowska, "The Pseudo-Lullian Origins of George Ripley's Maps and Routes as developed by Michael Maier," Mapping Invisible Worlds, Gavin D. Flood, ed. (Edinburgh: Edinburgh University Press, 1993) 107-126, 107. Szulakowska describes the "map" of Ripley's journey, and its sources in Lullian, Psuedo-Lullian and Aristotelian cosmological maps that are based on ontological categories and distinctions in

${ }^{89}$ For 'squaring the circle' see Urszula Szulakowska, "The Pseudo-Lullian Origins of George Ripley's Maps and Routes as developed by Michael Maier." The Pythagorean and Orphic idea of squaring the circle in alchemy is well documented and discussed. The alchemist thinks of it in terms of the four elements and his aim is to transform them into the "quintessence," the transcendent fifth element which is the "Philosopher's Stone." Urszula Szulakowska describes its adoption by Ripley and European alchemists through Aristotle's square of the four elements in De generatione et corruptione, and through Psuedo-Lull, particularly the Testament, who eventually added to the square and circle the triangle of the trinitarian likeness of God — or body soul and spirit—in an effort to make the product "conform to the neoplatonic Augustinian theology of Catholic orthodoxy." Ibid., 117-120. Ripley specifically discusses the integration of the duality, trinity and quaternity into the unity of the circle, in the third Gate, stanzas 6-8, where he describes the three manners of conjunction, and tenth Gate, stanzas $7-11$, where he describes his famous wheel of the circulation of the elements.

${ }^{90}$ See stanzas 13 and 14 (part) from "Erroneous Experimetns" on page 127 below.
} 
poem, the classic universality of poetry. We as readers must yet "myne" out of hiddenness through interpretation, the self-conscious relationship Ripley has inscribed into his text, with that kernel of secret substances this text presumes to hide.

The literary value of the Compound was recognized early in the history of its reception. A clear example of this specifically literary reception appears in British Library MS Add. 5025-4 dated 1588, which is one of the sixteen extant 'Type I'91 manuscripts of the emblematic scroll attributed to Ripley and based on his Compound. "Ripley Scrolls" vary widely in size, from 5'x5" to 20'x3'.92 The Bodleian Catalogue describes Bodley Roll 1 in Oxford as the earliest, based on the mid-15 ${ }^{\text {th }}$ C. style of its written characters. McLean argues that none of the extant scrolls were produced any earlier than the 1500's, and that since Bodley Roll 1 has a piece of missing text, it cannot be the earliest. ${ }^{93}$ McLean nevertheless identifies evidence indicating that the "Ripley Scroll” must be directly connected with Ripley in its origin. ${ }^{94}$ Type I generally consist of a series of four panels depicting in coded, symbolical form, the stages of the alchemical 'work'. These together are framed, at their top and bottom within emblematic figures that

\footnotetext{
${ }^{91}$ In Adam McLean's Study Course on the Ripley Scroll (Glasgow: Adam McLean, 2002), p.3. McLean distinguishes two types of the Ripley Scroll. Of the 21 extant copies 16 belong to 'Type I.' He describes these as very similar. The remaining 5, belonging to 'Type II,' and are more varied. The Ripley Scroll, Mellon 41 (England, ca. 1570), which I have consulted, belongs to the main type, Type I, and is housed at Yale Bieneke Library. Its information and transcription are online at http://brblnet.library.yale.edu/pre1600ms/docs/pre1600.mell041.htm. They had published the "Scroll" online, and it was available in 2011, but have withdrawn it since. It is, however available in relatively high resolution online at http://upload.wikimedia.org/wikipedia/commons/b/bd/Ripley_Scroll.JPG, accessed 22 Feb., 2014.

${ }^{92}$ McCallum, R.I. "The Ripley Scroll of the Royal College of Physicians of Edinburgh," Vesalius, II, 1(1996):39 - 49, online at http://www.bium.univ-paris5.fr/ishm/vesalius/VESx1996x02x01x039x049.pdf, accessed on Aug.16, 2011.

${ }_{93}^{93}$ McLean's Study Course on the Ripley Scroll, 4.

${ }^{94}$ Ibid, pp. 10-11 and 55-56. McLean points out that the figure of the scribe at the bottom of the scroll- "“ the sort of person who might have made a copy of the Scroll" - carries a staff with a horse's hoof on its bottom end and a quiver, quill pen, and a roll of parchment on its top end (pp. 10-11). He then argues that the horseshoe appears to have been "perhaps used in his [family] coat of arms or as part of a personal seal," since the horseshoe is part of what seems to be a heraldic image painted on the head of Ripley's tomb, in a drawing of this tomb found in Elias Ashmole's personally annotated copy of his Theatrum Chemicum Brittannicum. This drawing he had copied from the now damaged MS Cotton Vitellius EX. fol 234v (pp.55-56) in the British Library.
} 
stand outside the work: At the top, with part of his torso behind the narrowing top part of the flask of the first panel, is a man drawn in much larger dimensions, giving the idea that the figures in the panels below are his work, or even that the action in the flask and panels below it, is transpiring within him. He is peering over the 'work' without looking at anything directly. Rather he has a contemplative look of wisdom in his eyes, directed into the inner distance. His hands rest on the top part of the large flask of the first panel. Presumably he is the alchemist or Hermes himself, who has attained wisdom. At the bottom is depicted a scribe on one side, with an empty space across from him on the other side, indicating that a figure was supposed to have been painted there. Two of the Type I manuscripts have the other side completed with the figure of a king across from the scribe. The two figures, scribe and king, form a contrast perhaps indicating the nature of the "Stone" or "Work" as a combination of the contemplative with the practical life, of thought with action and wisdom with prudence (applied, or practical wisdom). Perhaps they also point ot the relationship between text (the scribe) and hidden meaning (the king).

The four panels in between represent the "Work" as follows: the first panel depicts the negredo phase in which the stone is tortured, killed and separated. The separation includes three aspects, its male and female-duality, its body-soul-spirit triplicity and its four element quaternity. This panel is labeled "black Luna, black sea, black sol." The second panel presents the white (albedo) and red (rubedo) phases. It has both a vertical and a horizontal axis. At the top of the vertical axis is a large overhanging tree of knowledge, with a large 'Melusine' figure (i.e. half woman half dragon or serpent), depicted as a combination of Satan and the Holy Spirit, hangs from its serpent tail that is coiled along a branch of the tree. The "Melusine' figure is labelled "Spiritus," 
and presides over the action in the rest of the panel. Standing on a stump of the tree below this "Spiritus" is a child, whose hand it holds. This child has a fiery nimbus of light around him. He is labeled "Anima." The tree trunk runs down through the two parallel horizontal phases to the bottom of the panel. It transforms into a sturdy column, and is supported by a strong Atlas figure labelled "Corpus" and "Tera." The vertical axis therefore analyzes the action in terms of the srone's triplicity of body, soul and spirit. But it should not be understood as a static 'representation'. Rather it indicates a process and a bidirectional action in which the body will be raised into union with the spirit and the spirit will descend and become incarnate in the body. The vertical elements are far larger than the horizontal contents of the bath. They constitute elements of the macrocosm, in contrast with the castle-walled bath, which is the microcosm. These macrocosmic Spirit, Soul and Body do not stand alone. On either side of the tree where Spiritus and Amina hang, are the also large "planets": male Sol on the left side and female Luna on the right. From male Sol are dropping golden feathers, and from female Luna silver feathers, representing the male spiritual referent and the female sensible referent that are to be united together through the alchemical operation. The feathers are macro-sized and they fall fluttering on either side, all the way down to the bottom of the panel, framing both the white and red phases. The silver ones fall on the side of the female and the golden ones on the side of the male. So what happens inside the microcosmic castle walls is also happening on a macrocosmic level. The macrocosmic dimensions possibly imply that the Anima hanging immediately below Spiritus and high above Corpus, is the 'World Soul.' This, however, is not all. At the very extremes of the vertical axis are the foliage of the tree of knowledge, with each leaf consisting of a combination of spirit and soul ("Spiritus and Anima). If Spirit is the truth that the soul knows, the soul is the intentional act of 
seeking that truth and knowing it. At the bottom extremity of the vertical axis is the collective substratum of the entire Cosmos and the foundation of its operations: the Prima Materia, primal chaos, or Pre-Socratic arche and apeiron out of which the four elements that constitute the Cosmos first arose. It is the substratum which the four elements share and the common foundation which makes possible their ability to interact and to pass into one another, as Ripley's "wheel of the elements" prescribes.

The two horizontally parallel phases of this panel are labeled "white Luna, white Sea, White Sol" and "red Luna, red Sea, red Sol" respectively. These white and red phases are depicted each as a bath. The action within the bath occurs in terms of the dual structure of the stone: the male and female being joined together in the alchemical marriage. Each stands on one side of the tree trunk. In the white phase a miniature sun hangs above the man, a miniature moon above the woman, and the two are eating from the grapes of a vine twined round the tree-trunk. Their ingesting the presumably poisonous and healing grapes represents their absorption of the seven liquids or "imbibissio[s]" being poured into the bath by seven monks standing round the walls. In the red phase the man and woman are transformed. The woman is now a union of water and air. She has wings and is labelled "spiritus" and "water," and the man is now a union of air and fire, has a nimbus of both cloud and fire around him, and is labelled "anima" and "oyle." Perceived through much analysis of Ripley's and other alchemical texts, the man seems to represent the higher and etherial part of Air, in which the humidity of Air is united with the heat and light of Fire. The woman represents the lower part of Air in which the humidity of Water is united with the warmth of Air. Air is the unifying element between the man (fire and air) and the woman (air and water). It is the third term and the golden mean between fire and water, and between its own two halves. The lower half of 
Air, beneath the Moon, is united with Water, and its upper and aetherial half is united with fire. When the upper half (anima) and lower half (spiritus, since spirit is associated with Water) become "married," Air becomes the golden mean of the white phase of the alchemical marriage. It is the marriage of anima with spiritus. The red phase will consist of the marriage of these two (the Hermes Bird), with Earth. The containing walls of the bath in either phase look like castle walls, thus representing Ripley's Castle metaphor.

The third panel—which I understand through the clarification Thomas Norton provides in the fifth chapter of his Ordinal, in lines 2447-2454, that describe the "red werk"-is the union of the diagonal opposites in the square of the elements. Fire unites with Water and Air with Earth. To this union of the diagonal opposites in the elemental square Urszula Szulakowska refers sto "Aristotle's Tree," and discusses it in terms of the squaring of the circle. ${ }^{95}$ The panel depicts a spiritual "Hermes Bird" which is the result of the marriage in the earlier panels. The "Bird's" feathers indicate that the desired union of the sensible with the spiritual referent of knowledge is now accomplished, since each feather is silver on one side and gold on the other. The "Bird" (Air as third term) is plucking these feathers off itself and transferring them to the globe of Earth beneath its feet (Air uniting with its diagonal opposite, Earth), thus "fixing" its volatile self by uniting itself with the body ("Corpus" or "Tera"). It is simultaneously spiritualizing the body. The golden Sun above is being united with the silver clouds (Fire with its diagonal opposite, Water), and drops of moisture are dripping from it onto the figure of "Hermes Bird" standing on Earth. The fourth panel depicts the final reborn "Child": the equivalent of the risen phoenix and completed Philosopher's Stone. The Hermes Bird has been transformed into the green dragon of the prima materia. But now that green dragon is

\footnotetext{
${ }^{95}$ Urszula Szulakowska, "The Pseudo-Lullian Origins of George Ripley's Maps and Routes as developed by Michael Maier," pp. 117-18.
} 
strangely combined with God. It is an incarnate Christ figure in a sacrificial attitude. The combination of the dragon with God to form a Christ-figure at the end, is reminiscent of the combination of Satan with the Holy Spirit at the top of second panel. The ChristDragon figure has now made the Body, Earth, spiritual. As it stands on Earth its sacrificial blood drips from its heart to feed and nourish Earth. Altogether, the stages of the "Work" in all four panels reflect the process of fixing the spirit and spiritualizing the fixed, to produce a full-fledged, embodied and 'living' allegory in which matter and spirit are inseparable, and which is a microcosmic and indestructible entity.

One of the Ripley Scrolls, British Library MS Add.5025-4 provides additional and strong support to the idea that Ripley's alchemical process is a fundamentally literary one. It has a text added at its end, which puns on "matter" and brings attention to its "hidden sence." It also places emphasis on interpreting what one visually beholds, since its verses are an accompaniment to the Scroll's emblematic illustrations. Whether this unique tailpiece traces back to Ripley's authorship in any way, or is entirely the work of a collaborating interpreter, it is intimate with Ripley's literary technique - its mode of encoding meaning, and the sort of exegesis it demands - and it clearly presents the thenwell-known Ripley Scroll as a rhetorical "Ornament" rather than a piece of chemical information. Adam McLean has transcribed this tailpiece as follows:

Thus with all I am content To shew this comely Ornament.

Of these types and Figures your eyes doth beholde Mervellous MATTER the hidden sence doth unfolde But how and in what manner the same is effected In a written booke it is plainly directed Of the very ancient and most strange operation By Calcination and Sublimation Elevation and perfect Fixation To be good in Tincture and in Malliation In poys [weight] good, and in test the true probation And many things els this worke doth unfold 
Which at this time is too long to be told. ${ }^{96}$

In its triple pun on physical "matter," the figurative "matter" of the Scroll, and the verbal matter of its own verses, and in its emphasis on the interpretive function of its figures, this poem reverses the viewer and reader's attitude towards the Scroll, from his treating it as a source of information about a chemical process that is to be carried out elsewhere and at another time, to his reception of the Scroll as the actual site of the desired transmutation. In this passage, the text and images of the Scroll are one with the reader's mind as it enacts them by interpreting them. At the same time its material presence--both parchment and figures painted on it - is the vehicle through which the reader's mind incorporates the structure of the entire order of Creation that it encodes. The transmutation is "effected" through the "written booke" whose text the scroll interprets, and whose kernel it conceals in its figures. It is "effected," in turn, through the interpretive act of the viewer or reader of the scroll itself: "effected/ in a written booke" by means of the "unfolding" of its images and text. In other words, the text at the end of MS Add.5025-4 presents alchemical transmutation as taking effect in the viewer or reader, through a process of interpretation which uncovers the hidden meaning encoded into "these types and Figures." The pun on "matter" creates an analogical identity between the alchemical process and the textual one. Even a possible reference to an actual laboratory operation would not revoke the implication that it is the scroll, and through the scroll, the "written booke" that have to "calcinate," "sublimate," and "be good in Tincture," etc. The poet describes the "Mervellous MATTER" actively, relegating to it the "unfold[ing]" of the "hidden sence." Lines 13 and 14 suggest the temporality of the unfolding, "Which at this time is too long to be told." What is

\footnotetext{
${ }^{96}$ British Lib. MS Add. 5025-4, lines 1-14 of the tailpiece, Adam McLean's Study Course, p. 13.
} 
unfolding is at once the material "Scroll" with the inscribed figures, the reader's mind, and the entire ontological structure of both the universe, created by God, and the reader's own being- macrocosm and microcosm. In addition to these, one more thing is also unfolding, and this is the text that is produced as a result of the reader's act of interpretation. In one sense the text of the reader's own thoughts--into which he has inscribed the 'meaning' that he has discovered through his temporal process of interpretation-exists in the reader own mind. But in another sense, this new text into which the reader has inscribed this meaning is — back again — the same figures on the Scroll. Through his interpretation the reader re-creates the scroll.

But at the same time, the Scroll is also unfolding, temporally, God's eternal act of creation, since the "hidden sence" that the Scroll unfolds is the "root" of the Stone, which is divine knowledge proper to God, and is even Christ as the Word. While the description in the tailpiece verses has a secular character, it conceives of itself as carrying divine truth. In the next lines quoted below, the verse directly states that this Scroll is the world of God, and man only as His agent. This makes the Ripley Scroll reminiscent of St. Augustine's metaphor of the scroll to which Jesse Gellrich calls attention, ${ }^{97}$ and which St. Augustine constructs as a paradigm for the relationship between God's Word and man's. Augustine uses both the words "scroll" and "skin." In the following lines he uses the word "skin":

Who except you, our God, has made for us a firmament of authority over us in the form of your divine Scriptures? For "the heavens shall be folded together like a book" and now they are stretched over us like a skin. (XIII.15.13) ${ }^{98}$

\footnotetext{
97 Jesse M. Gellrich, The Idea of the Book in the Middle Ages: Language Theory, Mythology, and Fiction (Ithaca: Cornell University Press, 1985), 35.

98 John K. Ryan, ed. and tr., The Confessions of Saint Augustine (New York: Random House Inc, rpt. 2011), 312-313. All citations of St. Augustine's Confessions are from this edition.
} 
By God's "divine Scriptures" Augustine probably means both the biblical Scripture and Christ as Word. When human beings look at this Scripture from their fallen and mortal vantage point, they see the text of the Scripture in written human words. They also perceive it in the form of the sensible images of the world. Thus when thy look at God through the Scripture, the firmament becomes a scroll, on which man sees the Scripture in human words and sensible images. As a "skin" God has clothed with it our minds: "you have stretched out the firmament of your book like a skin, that is, your discourses, truly in harmony, which you have placed over us by the ministry of mortal men" (XIII.15.13). His everlasting and immutable divine Scripture shapes our minds. This scroll, the firmament, unfolds temporally, as the men who interpret God's Word "te[11] in time of you who made all times." But this scroll of their own human words that unfold in time can be folded up like a book. God's divine Scripture, however, will never be folded up. When these men pass from this world though death, and into His direct presence, they will, like the angels, be face to face with Him. They will read God's face without the "syllables of time":

They always behold your face,' and, without any syllables of time, they read upon it what your eternal will decrees. They read your will; they choose it; and they love it. They read forever, and what they read never passes away. For, by choosing and loving, they read the actual immutability of your counsel. Their book is never closed, nor is their scroll folded up, because you yourself are this to them, and you are this for eternity. (Conf. XIII, 15.18)

Augustine's description of the holy men's "choos[ing] and lov[ing]," while it directly refers to their reading God's face in Heaven, indirectly also refers to their reading the firmament temporally while they were still on Earth. While they were still on Earth, they also chose God freely. Their journey of interpretation led them to God because he was the referent of their intentionality, as they interpreted him to other men. These men-who 
have unfolded God's Word in time to other men, and who have then passed from this sensible world to God's immediate presence—once they've died, Augustine says, God gives the authority of His own Word to the words they had used on Earth: "by that death of theirs, the strong firmament of authority in the words you uttered through them is sublimely extended over all things that are beneath it." This implies that their passage through death, and into union with Him has rounded off their lives into a complete whole, and has made it transparent. Through their temporal hermeneutic labor while they were on Earth, they had become agents of divine action. Once they have passed through death, their union with Him recoils back onto their lives when they were on Earth, and onto their temporal agency that is still available to men in writing, and will allow God's eternal truth to be present in their words.

Like St. Augustine's "scroll" the "Ripley Scroll" unites the Divine and eternal Word with the human word. Like Christ it is a mediator between the two. It is a "skin," a boundary, a passage through death, and a vehicle for the recoil of the hermeneutic pilgrim's union with God, back onto the agency of his words on Earth, uniting them to God's Word. The written texts of these men who have passed through death into union with God, become infused with the divine truth they are, in eternity, reading in God's Face. Since Eternity collects all past and future into a constant present, the acts of reading God's Face without syllables of time while in eternity, are simultaneous with their past temporal acts when they were on Earth and reading temporally. The Scroll becomes a sort of wonder-ful, living and mediating boundary and a throbbing interface between God's mind and Word and man's mind and word. The throb of the Scroll is both God's and man's. In a sense, the throb is Christ's, the Man-God. 
It is important to note also that this union between the human text with the divine text is effected not only through the words and figures, but through the material scroll itself: This union "is effected / In a written booke," one that is material. The analogy that the Ripley Scroll provides to the hermeneutic process of poetic creation suggests the idea of spirit being "fixed" into matter. "Calcination," "Sublimation," "Elevation," "Fixation," etc., connect the verbal operation with the physical operation in nature. After all, the perfection of the "stone" is only complete when you "make thy bodies first spirituall, / And then thy spirits (as I have taught thee) corporal!" (VIII, 1.4-6). As we shall see, the passage through death is crucially important to this process. The "Philosopher's Stone" can only be formed through a recoil of the hermeneutical pilgrim's union with God. The Stone becomes a whole and a fully unified Allegory. Its microcosmic wholeness is suggested by the metaphor of the "comely Ornament," in line 1 . The metaphor of the "comely Ornament," also identifies the scroll with the Stone as microcosm and artistic opus: An ornament is a miniaturized aesthetic entity that is apprehended at once, just as the "Stone" is a microcosm which offers a redeemed form of immediate knowledge. These verses of MS Add.5025-4 also identify themselves with the "comely Ornament" through their playful feel and the enjoyable lightheartedness about them. In this play there is tension between the simultaneity and immediacy of the ornament on the one hand, and the unfolding that "at this time is too long to be told" on the other hand. It is a tension between the Stone's matter that is unfolding in time, and the Stone itself, which will be grasped with immediacy once the unfolding is completed and becomes simultaneously present to the wizened mind. The next stanza which completes the tailpiece tells us that this "Ornament" is the work of God, and that "Man" as artist is only 
His "simple instrument." Through the mediation of Man "God works and Nature brings to pass":

What shall I say that Man then maketh Gold Nay God forbid, we will not be soe bold For when a Man doth all his whole intent What is he but a simple Instrument By whom God works and Nature brings to pass The very same, by Art that compast wast Where Nature left, there Art doth but begin That perfectness that Nature could not winne Few words I meane at this time for to make This have I done for all true Students sakes. ${ }^{99}$

The author of the verses of the 'tailpiece' connects the temporality of the process of "mak[ing] Gold" with the eternity of God's "work." The author also thinks of Man's work in relation to his “intent." In doing so, he places Man's intentionality at the center of the action, locates his freedom of will in that temporality, and places his intentionality in the context of divine action. While "Man" does his "intent" God uses him towards His divine purposes. Man's artistic action, therefore, is part of God's action. The author thus gives a very high status to "Art," and his use of the generic word "Man" in the context of his "Art," suggests that he perceives an essential connection between artificial production and being human. The product of Man's art—-this comely Ornament"-is an entity that unites him with both God and Nature. This implies language in its redeemed sense- the language of 'wisdome' in which word and substance are one. Art, in this sense, becomes constitutive of Man, and Man becomes himself the Stone, and a living allegory.

The specifically literary reception of Ripley's Compound is then evident in the ‘tailpiece' of British Library MS Add.5025-4. Before we turn to Ripley's comprehensive, systematic and self-conscious textualization of the alchemical process, we will take a brief step into a wider perspective on the conventional role the Compound embraced as a

\footnotetext{
${ }^{99}$ British Lib. MS Add. 5025-4, lines 15-24 of the tailpiece, Adam McLean's Study Course, p. 13;
} 
member of the alchemical literary tradition. Ripley perceived his language and symbols to be embedded in the preceding texts in the Compound's alchemical lineage. Like these texts, the Compound claimed to disclose the sacred knowledge of alchemy which the fathers and previous masters had hidden in them. Ripley highlights his role in this tradition in the very important opening stanza of his "Prologue"-and of his Compound as a whole. In the first two lines of that first stanza, Ripley begins by asking his reader to "harken to my doctrine" and, as mentioned above, to keep in mind the "wordes of wisdome... / Which of olde fathers be true in sentence":

Childe of this discipline incline to me thine eare And harken to my doctrine with al thy diligence These words of wisedome in minde doe thou beare Which of olde fathers be true in sentence: Live cleane in soule, to God doe no offence. Exalt thee not but rather keepe thee lowe, Else will thy God in thee no wisdome sowe. (Prol., 1, 1-7)

Ripley begins by declaring his purpose, which is to impart to his reader the kernel or "sentence," that is enclosed in the old fathers' texts. We know that the majority of these texts are written in more or less encoded language, and their "sentence" is not immediately available. Ripley's language preserves the intellectual distinction between the textual "words" and their "sentence." But it also refers to these words" "wisdom" in its traditional meaning as redeemed language and substantial knowledge. It tells us that the old fathers" "words of wisdom" are true in their "sentence." This implies unity and identity between the old fathers' words and the substantial truth of the kernel, which is immediate. At the same time Ripley's declared purpose to impart that kernel of wisdom to his reader implies that to be an author he has first to be a reader and an interpreter of the "olde fathers"” (Prol., 1.4) texts. 
As interpretation of a procession of previous texts in its lineage, Ripley's Compound carries out two actions in opposing directions simultaneously: It joins the march of textual progress towards the recuperation of the primordial fullness of knowledge, and, simultaneously, it creates, through this very act of recuperation, a new integumentum that repeats the hiddenness of the sacred knowledge and re-asserts the gap between the text and the wisdom it purports to disclose. Ripley perceives this bidirectionality to be part of the function of the Compound in its artistic and philosophical capacity of guarding the secrets and reserving them for the elect, as well as in terms of its historical role within the alchemical tradition.

Barbara Obrist approaches the bi-directionality of the medieval alchemical literary tradition through her focus on the medieval alchemist's concept of history. Her description is closely relevant, even though she does not mention Ripley, and her focus is on Franciscan authors such as Roger Bacon and John of Rupescissa. She describes the "conception of the history of alchemy," in the Middle Ages, as genealogical. By this she means that medieval alchemical authors conceived of their works as descending from an original revelation through a line of texts, each interpreting those before it. Each new text interpreting the earlier one is an event of knowledge, as it receives the knowledge hidden in those earlier texts, re-interprets it, and rewraps it in a new integumentum. In the original event of revelation, knowledge was complete, and it guaranteed the unity of all ensuing events of knowledge:

During the Middle Ages, the prevailing conception of the history of alchemy was that of a genealogical line of descent - both carnal and spiritual - where the original paternal figure was invested with the role of ensuring unity of knowledge. The relationship between this figure and its descendants was one of genus and species. On an epistemological level, 
the genealogy of knowledge entails the idea of an initial full revelation of knowledge, and its subsequent (partial) loss and recovery. ${ }^{100}$

Thinking of the Compound in view of Obrist's description of the alchemical conception of history helps in articulating an understanding of the place Ripley gave The Compound within its literary tradition. As a textual event in the genealogical line of epistemological recuperation of the lost, sacred knowledge, an alchemical text brings the language of the present a step closer to the language of the primordial past when the alchemical knowledge was more complete. Among the original fathers who had the full knowledge, alchemical texts cite Adam, Enoch, Noah, Moses, Hermes Trismegistus, and sometimes even Edras, Solomon (or "Salomon"), David and John the Evangelist. ${ }^{101}$ Among less primordial or less Ancient historical figures Obrist mentions the inclusion of Cato, Virgil, Aristotle, Abu Ma'shar ${ }^{\mathbf{1 0 2}}$ among several others. The Turba Philosophorum gives Pythagoras as Hermes Trismegistus' son. ${ }^{103}$ The prologue to what may be the first book translated from Arabic to Latin, in 1144, the Liber de compositione alchimie, informs the reader of the antiquity of alchemical knowledge, claiming there were three ancient and divine men named Hermes, who possessed the sacred knowledge, being Enoch, Noah and Hermes Trismegistus. ${ }^{104}$ Trismegistus, a philosopher, king, and prophet, the prologue credits with founding the mechanical and liberal disciplines of knowledge soon after Noah's flood. Interestingly, it also credits him with the authorship of the Liber, which eventually came into the hands of Morienus who then imparted the knowledge it

\footnotetext{
${ }^{100}$ Barbara Obrist, "Views on History in Medieval Alchemical Writings," Ambix 56, no. 3 (November, 2009): 226-338, 226.

${ }^{101}$ Ibid. pp. 227-229; 231-233.

102 Ibid. p. 232.

${ }^{103}$ Ibid. p. 233.

${ }^{104}$ Ibid. p. 229, citing Lee Stavenhagen, “The Original Text of the Latin Morienus," Ambix 17 (1970): 112.
} 
contained to King Khalid ibn Yazid (d. ca 704 or 708). ${ }^{105}$ This makes Robert of Chester, its translator, in turn, a participant in imparting the hidden and sacred knowledge. Ironically, the text of the Liber, which was authored by Trismegistus, some time after Noah's flood, consists of a dialogue between men who lived millennia later, Morienus and late $7^{\text {th }}$ c. King Khalid. While Obrist makes no note of this irony, it supports her point that the alchemical treatment of history suppressed historical temporality. ${ }^{\mathbf{1 0 6}}$

Obrist also describes the Christian modification of the narrative of sacred history. Christianity modified the epistemological path of alchemy, to locate the "full revelation of knowledge" in the event of the Incarnation and the ensuing Scripture. Scripture came to "encapsulate[e] complete knowledge," and "its gradual acquisition became possible. Yet, fullness of knowledge is reserved to the end of history, for Scripture always retains obscurities in need of elucidation."107 Although Ripley was a canon of the Augustinian order, in whose avowed doctrine the historical Incarnation of Christ was the fundamental basis of the Christian faith, he does not give up the original sacred truth secretly transmitted through his "olde fathers." Rather, he emphasizes Christ as the Word—'the Book of God.' The seeds of this Word God hid in the primordial chaos which He created out of nothing, thus endowing its matter with the individuating principle and vehicle through Whom all creatures could emanate from Him into individual being. ${ }^{108}$ Ripley makes the Word, which is the invisible 'Book of God,' materially available in the visible 'Book of Nature.' As Gellrich explains, God's plan becomes present in the material signifyers: "as soon as a signifying system-words in Scripture, things in nature-

\footnotetext{
105 Obrist, p. 229

106 Ibid., 228.

${ }^{107}$ Ibid.234. For complete knowledge coming to be encapsulated in the Scripture, Obrist cites George Molland, "Roger Bacon and the Hermetic Tradition in Medieval Science," Vivarium 31 (1993): 140-60, 142.

${ }^{108}$ See the discussion below regarding Ripley's description of God's act of Creation (Pref. 6.1-7) in Chapter Three, page 179 in this document.
} 
became a metaphor for divinity: the entire preexistent "totality" of God's plan was potential in the signifying means." ${ }^{\text {109 }}$ These two books, he simultaneously seeks to "knitt"110 together into Christ-like visibility. The written text he is interpreting, however, he identifies as the artificial and man-made texts of the old fathers, who are "philosophers" themselves engaged in the "Art" of alchemy both to recuperate and to conceal the lost knowledge in their writing. He collapses the historical distance between Genesis and the Incarnation, and makes the Incarnation, which is the union of God and Nature, potentially available 'in the here and now'-borrowing Rudolf Bultmann's phrase - through the mediation of Art, and, in particular, text. Paradoxically, however, this ideally immediate 'here and now' of the event of sacred history is, unlike Bultmann's, to be temporally acquired through the laborious act of textual interpretation. Ripley is thus engaged in both recuperating a-potentially present—past revelation, and progressing to a more perfect future revelation, and doing that specifically through writing, which to him is essentially interpretive and bidirectional, at once disclosing and concealing. The wisdom the old fathers had sought and hidden in their texts, is the "marriage" of God and Nature in a microcosmic "Stone" that will not "flie" at the test by fire. It also unites the human word with the divine Word, so that the textual "words of wisdom" can be "true in sentence." The "sentence" that is to be recuperated from the old texts, and placed in a new text which captures it more perfectly, is substantially true: It is a truth that has the form of the incarnate Christ. It also is like the Scroll. It unites language with both substances: the physical substance of Nature which, as hyle, is below or anterior to, sensible perception, and the divine substance of the Spirit, which is ineffable and above and beyond rational perception. In their living immediacy, however,

\footnotetext{
${ }^{109}$ Gellrich, The Idea of the Book in the Middle Ages: Language Theory, Mythology, and Fiction, 35.

${ }^{110}$ See the discussion, below, of the metaphor of "knitting," 128-142.
} 
such substantial unions Ripley finds in the microcosmic lives and perfected persons of Christ-figures like Enoch and Elijah who were lifted bodily into heaven (Prol., 8.5-6), and like Daniel who could stay in the lions' den without harm (Prol., 9.5-7). These characters are "Philosopher's Stones" and living allegories, whose spiritual and moral perfection is inseparably united to their material bodies. In their lives and persons the hidden substance of God's truth is made visible. It is in this spirit that Ripley asks his reader to be humble and "cleane in soule," since without these, he will not be able to carry out the recuperative and redemptive act of interpreting the Compound's text properly or "philosophically"- an act which will transform him personally, and turn him more closely into one of those "Philosopher's Stones" himself.

\section{Philosopher's Stone and reader: Opus and "Childe"}

The genealogical descent of alchemical texts, as Obrist describes it, implies that the interpretation each new text in the tradition makes, affects the entire tradition backwards, as well as forwards. This in turn implies that from the view-point of an alchemist, Ripley's comprehensive and radical textualization of the alchemical process, and his rendering of it in terms of poetic creation, implies his insertion not only of his own work, but also of its entire genealogical tradition into the general English and Western European literary tradition. Not only does the concept of artistic creation he advances transform the line of texts in its alchemical tradition, backward and forward, but it also affects in the same way the wider poetic tradition of which it has become a part.

Since Ripley's Compound is specifically concerned with the alchemical operation to produce the "Philosopher's Stone," his textualizing of the alchemical operation would have to answer to the characteristics of the artistic opus implied in this "Stone." As an artistic opus, the "Philosopher's Stone" which the Compound of Alchemy claims to 
secretly disclose boasts implications of redeemed language, immediate and substantial knowledge or "wisdom," full engagement and immersion, and a perfect and enduring work of art. Its implications include self-enclosure, organic unity, embodiment, a cosmic operation inside a hermetically sealed flask, microcosmic wholeness, the allegorical significance of objects in nature seeking to rise beyond themselves, words that rise beyond language, the transcendent fusion of opposites at the paradoxical point of their golden mean, the ascent to divine wisdom, and the union of the human individual—body included - with the Logos. It also implies catharsis and the ability of the opus, once completed, to be simultaneously present to the reader as an act of Aristotelian theoria, in which resides the human being's highest form of happiness. Such implications widen the range of experience covered by the artistic operation to the extreme limits of existence, from its lowest to its highest. The operation must cover the widest range from one liminal end to the other of existence, and from the lowest still-point of existence, in the utter depths of matter, to the highest limit where nature ends. The narrative sequence in the middle will be sandwiched between something other than itself, and beyond its modal limits. This sequence from beginning to end is the raw matter in the middle which will be transformed into a "Stone": a microcosm. Temporality is the raw material of thought and of process. As such it is the raw material of the allegorical interpreter. Through allegoresis the alchemist must bring time into union with eternity. His Supreme Allegory is both eternal and temporal, both material and spiritual, both an embodied thing "out there," and an intention.

The Compound, therefore, as an act of interpretation, is a paradox: it would not be easy to find a text that more consciously and deliberately opens an aporia between text and meaning, and call the reader to interpret, since without interpretation he would 
almost have no text- or, the text would make no sense. At the same time, it would be hard to find a more intense affirmation of human creativity and rejection of capitulation to that aporia. It is precisely within that aporia that Ripley locates the creative act: the intentionality through which the interpreter weaves his eternal vision into time, and embodies the divine truth he receives through his act of knowledge in the prime material of his art. George Ripley, towards the closing of the more than a millennium long era of the Middle Ages and the turn into the Modern, was diligently working to fuse ${ }^{111}$ earth with heaven into a paradoxical and indestructible entity that resisted the 'test by fire,' and overflowed the world even as it individually stood and acted within it.

Ripley indeed sought to combine Earth with Heaven by alchemically "growing" (VI.20, 23; VII.4; XI.5) a piece of earth into "our heaven incorruptible" ("Epistle," 21) ${ }^{\mathbf{1 1 2}}$ and passing it "from the darkness of purgatorie to light / Of Paradise" (V.14). He sought to give 'birth' to a "child" (VI.11; VIII.5), the alchemical "Philosopher's Stone," whose being encompassed the entire range of existence from formless matter at the bottom-most limit of reality, to the state of deified wisdom, at its ultimate heights beneath God. This "child" was independent of him, and had a life of its own. It was a transcendent "quintessence" (IX.18) or "fifth nature" (IX.17), and "Elixir of great might" (V, 14) which could heal the sick (IX.18), and give new life to the dying. The ideal and implied result of Ripley's journey of alchemical transmutation was a paradoxical opus, a work of art which moved and acted within the world, but which ontologically exceeded the world in an immeasurable and incomprehensible way.

Ripley's descriptions of the nature of the "Stone" as a marriage of ontological entities pervade the Compound. The idea of spiritualizing the body and embodying the

\footnotetext{
${ }^{111}$ See the quotation from the Compound (VIII, 6. 4-7), at the opening of this chapter.

${ }^{112}$ Linden, George Ripley's Compound of Alchymy, 89-97.
} 
spirit is a basic feature of the "alchemical marriage" described in the influential Rosarium Philosphorum, attributed to Arnold of Villanova, and which had become richly illustrated by the early fifteenth-century. In the "alchemical marriage" depicted in the Rosarium, the union between male and female cannot be fulfilled until they are both also married to the divine Spirit. In part four of the Rosarium "Arnoldus" explains that the soul, by going back and forth between heaven and earth "will receive the strength of the inferior and superior": "Sow, therefore, the soul into the white foliated earth because that retains it. Because when it would ascend from the earth into heaven and would descend again into the earth, it will receive the strength of the inferior and superior."113 The illustrations depict the soul as mediator between the joint, androgynous, male and female body in the sepulchre, and the Spirit in heaven. It is depicted going back and forth between the clouds at the top of the sealed and microcosmic glass vessel (heaven), where evaporation will again condense, and descend back down to earth, at the bottom of the vessel, where the bodies lie in a state of primordial materiality. Echoes of this illustration are frequent in the Compound and attached pieces of poetry, as in the first line of stanza 27 of Ripley's "Epistle to King Edward IV," which states "In bus and nibus he shall arise and descend." Ripley's Compound. The eighth Gate, "Of Sublimation," is particularly replete with them, such as evident in the quotation with which this chapter has opened. Like the Rosarium, Ripley ascribes the mediation between heaven and earth, or spirit and body, to the motivated soul. Like Hermes, who is the messenger between heaven and earth, the

\footnotetext{
${ }^{113}$ Arnold of Villanova, The Rosary of the Philosphers, ed. and commentary by Adam McLean, The Alchemy Website, nd., np., http://www.alchemywebsite.com/rosary0.html, last accessed 30 Mar., 2014. McLean cites his source as the 18th century English translation of the Rosarium in MS Ferguson 210, which in turn had been based on part II of De Alchemia Opuscula complura veterum philosophorum... (Frankfurt, 1550).

${ }^{114}$ Linden notes that "nibus may be an error for "nubilous" (cloudy) from nubes (cloud)." Linden, George Ripley's Compound of Alchemy, 130.
} 
soul mediates between the two to accomplish their "alchemical marriage." By "conjoining" the body of both with spirit, the soul brings heaven down to earth and at the same time, conjoins textual "matter" and spiritual "sense" into an allegory. The resulting "Stone" is a figure of the incarnate Christ, and the likeness of God, whose internal unity Ripley thinks of as "consubstantiall," explaining that one of the reasons for "sublimation is so "that the spirite may corporall bee,/ And become fixt with it [the body or corpus], and consubstantiall" (VIII, 7.4).

The alchemist, then, aims at a product that is in the likeness of the divine Trinity, and a figure of the incarnated Christ. Its matter is spiritual, and its spirit materialized. It is a microcosm that encapsulates the entire ontological structure of reality, including the epistemological modes belonging to that structure.

To complete our sketch of the "Philosopher's Stone" and the poetics it implies, we turn from our description of its nature in general, to a description of its identity as a character in Ripley's alchemical opus. For this we must turn back again to the opening stanza of the "Prologue." In this opening stanza Ripley identifies his opus with his reader. His reader is his pupil and alchemical initiate, and he addresses him as "Childe." Very importantly, "Childe" is the same word Ripley frequently uses to refer to the "Stone." It is not merely by conventional habit that he uses this appellation for his reader. To emphasize it, he places it at the very strategic points of the opening of his Compound and at its very end. He even begins his entire Compound, including its "Prologue" with this word. "Childe" is the very first word of the very first line with which he opens his opus:

Childe of this discipline incline to me thine eare And harken to my doctrine with al thy diligence These words of wisedome in minde doe thou beare Which of olde fathers be true in sentence: 
Live cleane in soule, to God doe no offence.

Exalt thee not but rather keepe thee lowe,

Else will thy God in thee no wisdome sowe. (Prol., 1.1-7)

Ripley is starting from the end of the alchemical journey: he has completed his own journey, has achieved wisdom, and is now, himself, a fecund "Philosopher's Stone," which can multiply by turning whomever it touches into gold. The opening of his Compound is the beginning of his act of imparting the healing and perfecting wisdom he has gained, to others- though, we will discover that this imparting is a collaborative labor of encoding and decoding, an exitus and reditus of meaning, between him and his reader. He begins by sowing the 'seed' of wisdom - "seed" being another traditional metaphor for the stone - into his reader's mind. In doing so, Ripley is God's agent, since God is the source of wisdom. His seed is made of words. To sow it, he asks his reader to "incline to me thine eare." The seed, which is his word, will grow into his opus, which is his "Childe," and the reader himself. Significantly, it is also God's child: In the first three lines of the stanza Ripley sows "These words of wisedome" into his reader's ear. Then, without elucidating the transition, the last line shifts the sowing action from Ripley to God and tells the reader to stay away from pride "Else will thy God in thee no wisdome sowe." The sense or "sentence" of the words Ripley sows is not an extension of his own mind, but comes from God's seed. Neither are the textual words he sows merely his own, since they also come from the texts of the "olde fathers." The seed the reader receives will 'grow' through the transformative journey of the Compound, until he too becomes a fecund "philosopher's stone," himself a "multiplier" who will impart his wisdom to others. At the end of the twelfth Gate, Ripley ends his Compound by returning to his reader as his "childe," one who has now completed the journey and is ready to multiply his stone by imparting his wisdom to others: 
Now childe of thy curtesie for me that thou pray,

Sith I have tolde thee our secrets all and some,

To the which I beseech GOD by grace thou mayst com.

8. Now hast thou conquered these gates twelve, And all the Castle thou holdest at thy will, Keepe thy secreats in store to thy selfe, And the commaundements of God looke thou fulfill, In fire see thou continue thy glasses still, And multiply thy medicines aye more and more, For wise men doe say, that store is no sore. The ende of the twelve Gates, intituled Ripleys Compound of Alchymie. (XII.7.5 - 8.7)

Thus the Philosopher's Stone that the operation of the Compound seeks to produce is the reader himself. The end of the journey will be another beginning in which the reader, like Ripley, will sow, in participation with God, the words of wisdom into the ears of his readers, fulfilling the shape of the Compound's circular Castle with the twelve gates. The Compound is thus embodied in the paradoxical and bidirectional moment of learning: that of the teacher's utterance and the pupil's reception. The new child who will rise like the phoenix out of the ashes of its parent-or teacher-will be the reader. At the same time, this child will be the new text into which the reader will have encoded the sacred knowledge he has recuperated, and this new text will, likewise, have arisen out of the ashes of Ripley's text.

The opening and closing of his Compound, therefore, indicate that the reader who has inclined to Ripley his ear, and harkened to his doctrine, has now been transformed into a Philosopher's Stone, ready to appeal, himself, in turn, to other readers' ears and transform them into gold as well.

We can now turn our attention to the body of the Compound in order to discover the process through which Ripley imparts the old fathers' sacred wisdom to his pupil so as to transform him into the "Philosopher's Stone." 


\section{The Compound's Non-Immersive text}

One would expect that a literary text which aims at transforming its reader into a "Philosopher's Stone," would itself exhibit the implied characteristics of that "Stone." For the reader to experience the visionary immediacy of apprehension and the identity of truth with being, wouldn't he have to experience an affective and imaginative immersion in the text, as for example one would in viewing or reading Shakespearean drama? On the contrary, Ripley seems to have no interest in such immersion. In fact he is constantly reminding his reader of the need to interpret, and "understand" his text "wittilie." The reader who expects to be admitted into a golden world upon beginning to read the Compound will be sharply disappointed. She will be faced with language that actively occludes the affective and imaginative immersion and the immediacy implied in the characteristics of the "Philosopher's Stone." She will be faced with a body that is a "our Bazeliske" and "our Cockatrice” (Pref., 24.6) "our Magnesia," and "our Adropp," (II, 2.4), water that is air, fire that is water, a duality of Sun and Moon that is a trinity, "earthly grossness" that must be "mortified" (VI, 7.1), "sperme and heate" that are "sister and brother" (VI, 17.5), a "Lyon green" which is "uncleene," but yet can be the "meane the Sunne and Moone betweene" (Pref., 16.2-5), "venome" that "blacke ... doth appear/ Becoming spiritual" (VIII, 5.1-3), "bodies" that are to be turned into "oyle" (IX, 18.4), a fire "against nature" that "is our Dragon" (III, 15.5-6), a "Sunne" that will "passe the waters of Noes flood" $(\mathrm{V}, 12.1-2)$ and the list is practically inexhaustible, unless one simply recites the majority of the text. The obstacle to immersion is not merely caused by the secretly encoded language. A reader, who seeks to interpret the language of the Compound into familiar and logically connected discourse merely by discovering the secret literal terms equivalent to the alchemical symbols will not get very far, and may 
become alienated and dismissive. He can also be one of the "fooles" who think they understand. Ripley even caricatures his own language by placing it in the mouths of those "fooles" and false "philosphers":

How eloquently de Materia prima their tungs do clap, And yet to finde the truthe they have no hap; Of our Mercurie they meddle \& of our sulphure vive, Wherein they dote, and more and more unthrive.

24. For all the while they have Philosophers bene, Yet could they never know what was our Stone, Some sought it in dung, in urine, some in wine, Some in starre slyme (for thing it is but one), In blood, in egges: some till their thrift was gone, Dividing Elements, and breaking manie a pot, Sheards multiplying, but yet they hit it not.

25. They talke of the red man and of his white wife, That is a speciall thing, and of the Elixers two, Of the Quintessence, and of the Elixer of life, Of honie, Celidonie, and of Secondines also, These they divide into Elements, with others moe; No multipliers, but Philosophers called will they bee, Which naturall Philosophie did never read nor see. (V, 23.4-25.7)

While Ripley makes fun of the alchemical language in the mouths of fools, however, it remains true that, like the alchemical fathers and masters before him, he does conceal the sense which he discloses, in alchemy's esoterically symbolical language, and does so with the conventional excuse of reserving the alchemical secret for the initiates, and preserving it from the foolish "multipliers" (V, 19.7 and 25.6), "Because that fooles should never know our stone" (V, 22.2). We can understand that these false "philosophers" are to be kept off because they are motivated by greed. But this excuse leaves much to be answered: What does the spiritual and moral quality of one's motives have to do with learning the hidden code- the "allos" to which each sensible symbol refers? How would Ripley's advice to the reader to be "cleane of soule" (Prol, 1.7) enable 
him to be a better interpreter? What is the connection between base or lofty motives and interpretation, and does this have anything to do with the way Ripley could possibly expect his Compound to be a "Philosopher's Stone" while he presents the reader with a text that deliberately disallows immersion and requires significant interpretive labor?

In "Allegory and Allegoresis," Rita Copeland and Stephen Melville argue that the language of secret codes is not a properly literary or poetic sort of allegory. ${ }^{115}$ In coded language, the signifier is entirely dropped for the signified. That would imply "the conveyance of meanings understood as fully separable from their linguistic integument,"116 which Copeland and Melville consider to be more properly "translation" rather than allegoresis:

We can mean one thing while saying another under certain special conditions whose most frequent practical instances are situations that demand secrecy or the avoidance of censorship; we construct a code known only to initiates such that they understand the real meaning of an otherwise innocuous communication.... If we do take this view of allegory, we are committed to understanding its workings in close proximity to those of translation in general, and we are committed to a view of translation that sees it as above all the conveyance of meanings understood as fully separable from their linguistic integument. ${ }^{\mathbf{1 1 7}}$

The language of alchemy is, likewise, secretly coded. But, while the Compound's alchemical language is coded, it uses coding only as a first step to the rest of the meaning. The sort of meaning production that the Compound professes to make is exactly the opposite of the divorce of meaning from integument typical of the language of secret codes. On the contrary, it aims at a bonding between the two that will withstand the "test by fire." While decoding is indeed indispensable for understanding the language of the Compound, it is only a sort of pre-requisite before the reader graduates to the level of

\footnotetext{
${ }^{115}$ Copeland and Melville, "Allegory and Allegoresis, p. 179.

${ }^{116}$ Ibid.

${ }^{117}$ Ibid.
} 
'interpreter.' As indispensable and helpful as knowledge of alchemical verbal equivalences may be, the reader will find out that verbal substitution is insufficient for stitching-over the logical gaps and providing a coherent context of understandable discourse. Least of all would this verbal substitution transform the text of the Compound into a continuous narrative scene. The question will still stand, as to how Ripley could expect to present his reader with a healing "Philosopher's Stone" without her immersion into the narrative world, and how it is that the correct interpretation of the Compound's text would depend on the reader's moral and spiritual condition. Finally, these conundrums lead to the further question, and the main question addressed in this chapter as mentioned above, that of the relationship Ripley has set up between the act of interpretation, or "allegoresis," and the 'Supreme Allegory' of the "Philosopher's Stone" and hidden kernel to be extracted through allegoresis. We can now rephrase this last question: If the "Stone" Ripley is transmuting is his reader, in which way would he expect the reader's act of reading to accomplish this transmutation, and make his own being a heaven on earth?

To the contrary of immersion, the text of the Compound offers itself to the reader in a self-conscious and artificially belabored form which the reader must meet with an equally belabored form of interpretation. Ripley's voice constantly reminds the reader to interpret and not to take his words at face value. The Compound is strewn with flags for interpretation, such as: "Take heede therefore, and understand me wittelie" (VII, 1.4); the false philosopher (and thus false interpreter) "conceaves not our words aright" (I, 4.7); "The wheele of Elements then canst thou turne about/ Truely conceiving our writings without doubt" (I, 17.7); and you can draw oil out of the hardest rock "if thou be witty" (III, 3.5). Ripley often refers to his text as "writing,"-as in the example I, 17.7 just 
mentioned- which reinforces one's awareness of the text's lack of immediacy. In addition to persistently highlighting the need for interpretation and reminding his reader to "understand" him "wittelie," Ripley's paternal and teacherly voice requires of the reader a radical sort of interpretation which self-consciously tears the textual elements apart, and reconstitutes them into a new text. Ripley makes the gap between text and meaning hard to ignore not only in its semantic aspect, but also semiotically, in the way he puts his signifiers together without a clear logical connection between them. $\mathrm{He}$ creates an aporetic text whose elements he pieces and "conjoins" together artificially, and allows the seams to show, similarly to the "conjointure" Chretien de Troyes sought to make with his own texts. But Chretien does provide our imagination with a "world" and with a background scene for the praxis of his characters; and he does allow us affective engagement, even as he asks us to periodically exit and observe the seams. Ripley goes much further in bare artificiality, giving no fictional or literal background scene to his characters of Sunne and Moone, who get married, die and are reborn, or to earth, water, air and fire- which are constantly acting or being affected by action. Without a context of some kind of familiar discourse, the reader is faced with a situation where he must interpret while being simultaneously cut off from the normal contexts on which he relies for interpretation.

Ripley's description in Gate III, for example, of the elixir which is both poisonous and healing, can illustrate the text's resistance to the usual kind of contextually derived interpretation. In stanza 11 of Gate three, quoted below, the pronoun "it" in the first line refers to the poisonous water of the previous stanza: "water wherewith thou mayst revive the stone" (III, 7.1); "A stronger poyson [than this water] cannot be thought" (III, 9.4); it 
is a "triacle" (III, 9.2 and 10.1), which, like Plato's "pharmakon," famously deconstructed by Derrida, is both "poyson" and "medicine elixerate" (III, 9.7):

It [the water] is a marveilous thing in kinde, And without it can nothing be done, Therefore Hermes called it his winde, For it is up flying from Sunne and Moone, And maketh our stone flie with it soone, Reviving the dead and giving life, To Sunne and Moone, husband and wife. (III, 11.1-7)

The language of these verses resists the normal mode of discourse which would permit the reader to interpret automatically or unconsciously. Certainly, Ripley's intended reader would have been familiar with alchemical symbolism, or would have had to familiarize himself with it. We know that we must resort to antecedent alchemical literature, and seek to find out the coded equivalences for each term and image; and we can do that in so far as that is possible, alchemical language being rather fluid, with characters that seem to subtly change their assigned roles or qualities from text to text, or even within the same text according to the demands of the paradigmatic arrangement. But how far will those equivalences provide logical continuity between the characters or their actions? A reader with a little familiarity with alchemical symbolism would know that "Sunne" and "Moone" are equivalents to male sulphur and female mercury, bound to become gold and silver, though it is uncertain precisely what particular materials the former couple, "sulphur" and "mercury," in fact stand for. He would know that the alchemist seeks to "marry" them together to obtain the phoenix-like birth of their "child." He would know that water and air are two of the four elements, and that by balancing the proportions of the four elements constituting his androgynous stone, the alchemist seeks to perfect it so that it can be reborn as an embodiment of the perfect "golden mean." But this does not change the fact that, in comparison to those of the usual literary text, the 
characters seem to belong to some context that is missing. Ripley's language provides no logical or visual continuity between one character and another ("water" is Hermes' "winde"), between a character and its actions (the "water," which is the "winde", flies from "Sunne" and "Moone"), or between each action and the following action (it flies from "Sunne" and "Moone," it makes "oure st'one" fly, and it revives the dead). We are unable to imaginatively place "Sunne," "Moone," "water," "winde," "Hermes" and "oure stone" against a visually coherent and continuous spatial expanse so as to foil their praxis into visibility, and perceive it in connected and comprehensible narrative form. One can apophatically point out the invisible gaps - the 'missingness' of context or backgroundjust as Urszula Szulakowska could "see" a sea surrounding the Castle with the twelve gates although there is no description of the Castle's surroundings. ${ }^{118}$ Since space is the raw material of the imagination — or at least since space, like time, is an a-priori category of the mind - the reader tends to perceive images against a background scene. The spatial scene is the mind's sensible representation of context. The context interprets the images just as the images interpret the context. But "Sun" and "Moon" Have been plucked away from the natural spatial scene that contains them in the sky. If one tries to place them back there, the text will remove them again, since the sky we have brought from our habitual perception into Ripley's text, does not have or explain Hermes' "water" which is his "wind," flying out from "Sun" and "Moon." Neither can the scene of the natural sky give logical, spatial, or natural continuity to the idea that Hermes' "water," which is his "wind," soon makes the "stone" fly with it. Where did the "stone" come from? What background or context did it emerge out of? If it emerged out of "Sun" and "Moon"

\footnotetext{
118 107-126, 107

Urszula Szulakowska, "The Pseudo-Lullian Origins of George Ripley's Maps and Routes as developed by Michael Maier," See discussion on 73-4, and n. 72 above. .
} 
together, Ripley's language doesn't tell us directly. We have to make an interpretive leap to understand it that way. The "scene" constantly returns the responsibility for the meaning back to the reader. The reader is left with characters without a continuous scene. The 'scene' is porous, consisting only of characters without a background. They are suspended in vacuum. The "scene" is therefore aporetic. We do not "see" the context in which these characters are acting or being acted upon. Due to the isolation of each image from any scene, these characters give themselves to us disconnectedly. We receive them as spots suspended in vacuum (somewhat like Nietzsche's spot of Apollonian dream rising out of the depths of the Dionysian darkness). We therefore receive not only the images, but the gaps between them as well. Ripley uses this absence of normal connections to sharpen the edges of his sensible elements. We receive each individual character as we do the Castle itself, of which they are constitutive elements: suspended, as it were, in a nameless and imageless infinity. Yet the reader has to connect the characters with each other, and make sense of their praxis- the action in which they are presumably collaboratively engaged. In this sense, the gaps are the apophatic location of our own intentionality - our own action. The imageless presence of the gaps locates the invisible and hidden "meaning" for which we must search in order to make sense of the text. Through interpretation, we move the "stone" along its transformative course. Thus the Compound insists on making its readers essentially interpreters-makers of meaning - but paradoxically stripped of their normally available sources of habitual and derivative interpretation. One either decides that the language is too weird for serious consideration, or one consents to put away one's normal modes of discourse as sources of interpretation, and look for leads that Ripley may have placed in his text, just as God 
placed the 'seeds' of His likeness, his Word and act of Creation, in the prima materia. The leads we will find guide us to do more than make mere correspondences.

\section{Isis and the "Well Conceaved Fruit"}

Ripley guides his reader to the right way of interpreting his Compound. Of course, the first help Ripley gives his student is through the strategically located flags that frequently pop up in his text, to remind his reader to interpret. These reminders often locate a kind of interpretation which involves a reversal of expectations where the apparent text turns out to mean something quite different from what it seems to mean. This reversal, however, is not merely semantic. Rather, it involves a rise in awareness: a turnaround in one's attitude towards the way the text means. The following stanzas from the first Gate, "Of Calcination" are such an instance of epistemological peripeteia:

4. And for a sure ground of our true calcination, Worke wittely only kind with kind:

For kind unto kind hath appetitive inclination, Who knoweth not this in knowledge is blind, He may foorth wander as mist in the wind, Wotting never, with profite where to light, Because he conceaves not our words aright.

5. Joyne kind to kind therefore as reason is, For every burgeon answers his owne seede, Man getteth man, a beast a beast Iwis, Further to treate of this it is no neede. But understand this poynt if thou wilt speede, Each thing is first calcined in his owne kind; This well conceaved fruite therein shalt thou finde. (I, 4.1 - 5.7)

"Worke wittily," Ripley advises his reader and "understand the point if thou wilt speede." The ignorant reader will not profit from his text, "Because he conceaves not our words aright." "Air" or "winde" is the realm of rational abstraction. The mind of the interpreter "who knoweth not this" will be as lost as the rational abstractions-species 
and genera - that float rootlessly and are disconnected from substantial knowledge. Thus, this kind of interpreter "may foorth wander as mist in the wind." Ripley is indirectly warning the reader that his statement "joyne kind to kind," because "Man getteth man, a beast a beast," must not be taken at face value within the natural modes of knowledge. The reader must interpret, and do so with deliberation, if he is to benefit from these statements. Ripley is in fact asking his reader to allegorize. The "well conceaved fruite" is the Philosopher's Stone, and, as the pun indicates, the fruit is "coneaved" also in the mind. "Therein shalt thou finde" implies the reader's unraveling of the integumentum of Ripley's words, since it refers to the "poynt" that he must "understand." Of course, what the "poynt" itself refers to, is hidden in obscurity. It is by interpreting the text that the initiate reader will discover the "point," the kernel within, and obtain the fruit of his labor of "conceaving" the meaning well. In the opening stanza of the same gate, Ripley already hints at the kind of interpretation he wants from the reader:

After philosophie I you behight

Doo, but not after the common guise, With Sulphures or Salts preparate in divers wise. (I, 1.5-7)

On the surface, Ripley seems to be informing the reader that the correct materials to use are other than "Salts" and "Sulphures." So the unwary reader would then surmise about the correct chemicals to use, and look for clues in the text that might disclose these materials. But Ripley gently drops the second sort of hint with which he strews his text. But even the phrase "after Philosophie" can be misconstrued by the reader to be no more than the conventional way of referring to alchemy. Such an interpretation would be typical of the mind that is immersed in the sensible world and limited to the natural mode of knowledge. The wary reader, however, will take the hint and recognize that he has to perform his transformative alchemical operation "philosophically" as opposed to 
"manually" (III, 1.3; V, 21.3), and with intellectual materials rather than physical ones. Do not work, Ripley advises the reader, with material sulphurs and salts, as do the foolish multipliers. Rather, work "after philosophie."

In philosophical terms--the language of the mind--couples of the same "kind" can belong to more than one epistemological network of relationships. The "Philosopher's Stone" proportionately unites the four elements of earth, water, air and fire, which are ontological "elements," each with its specific epistemological mode of truth. Water and air are in the middle as sensible knowledge and natural reason. They are the realm of natural knowledge. Earth and fire are on the extremities, as primordial matter and the divine substance alternately. The one is below visibility and anterior to the senses, the other ineffable, beyond the limits of reason. Each of the four modes has its distinct network of internal relationships, starting from the potential network encoded within the "seeds" which constitute the prima materia, through the sensible mode, the rational mode, and finally the relationships among the divine Trinity. The four networks are analogically related. The alchemical marriage is not fully accomplished until the mind has risen through the analogical networks and is able to retain them together simultaneously, each in keeping with its own internal laws. The foolish multipliers will usually absolutize the sensible mode and unthinkingly assume a merely sensible kind of marriage "With Sulphures or Salts preparate in divers wise.”

On the surface the "kind begets kind" type of phrase seems to state the law of natural reproduction as a rhetorical way of warning the initiate to stay away from the wrong chemical ingredients, such as "corosives," "vineger," "water ardent," or "vapour of leade" which he advises avoiding in the preceding second stanza of the Gate. This, however, cannot be its intended meaning, since after all, the alchemical operation indeed 
aims at transmuting one species into another, and the "alchemical marriage" will beget another kind. Out of a piece of metal, such as copper, will come gold. Even though both share the same genus as metals, they belong to different species, and copper will beget another species, gold. The change of species was a central issue of debate during the late Middle Ages, and the "kind begets kind" sort of phrase could not have escaped the weight of this debate. At the center of that debate was a statement by Avicenna (9801037) which was generally mistaken to have been Aristotle's, ${ }^{119}$ and which held that transmutation was impossible, and that art only superficially mimics nature, and cannot reproduce it:

Art is weaker than nature and does not overtake it, however much it labors. Therefore let the artificers of alchemy know that the species of metals cannot be transmuted (Quare sciant artifices alkimie species metallorum transmutari non posse). . . . I do not believe that it is possible to take away the specific difference by some technique because it is not due to such [accidents] that one complexion is converted into another, since these sensible things are not those by which species are transmuted; rather they are accidents and properties. For the differences of the metals are not known, and since the difference is not known, how will it be possible to know whether it is removed or not, or how it could be removed? ${ }^{120}$

This passage from Avicenna came to be well known, and in reference to it, the argument of the intransmutability of species, and limitation of art to mere mimicry, came to be referred to by the incipit "Sciant artifices" or "let the artificers know." The medieval upholders of alchemical transmutation had to find a way to explain the transmutation of

119 William R. Newman, "Technology and Alchemical Debate in the Late Middle Ages," Isis 80.3 (Sep. 1989): 423-445, 427. William Newman attributes the source of this mistake to the fact that Alfred of Sareshel inserted a piece of text he had translated, around 1200, from Avicenna's Kitdb al-Shifä (The Book of the Remedy), into book 4 of Henricus Aristippus' earlier translation of Aristotle's Meteorologica. "This short text, which came to be known in Latin as De congelatione et conglutinatione lapidum, immediately acquired the authority of a genuine Aris-totelian production, since it appeared to be the conclusion of the Meteorologica's fourth book. It became thereby the locus classicus for all subsequent attacks on alchemy" (427).

120 Quoted in William R. Newman, Promethean Ambitions: Alchemy and the Quest to Perfect Nature (London: University of Chicago Press Ltd., 2005), p. 37. 
species, since only God can create, and therefore transmute, species and genera. They therefore solved the problem by arguing that the piece of metal is returned to its prima materia, where it entirely loses its previous individual form, and thus its species. Only from there does it acquire a new form, and a new and more perfect proportionality among its basic four elements. William Newman and, earlier, Lynn Thorndike, credit Albertus Magnus with such an argument. ${ }^{\mathbf{1 2 1}}$ Newman points out and stresses the basis on which Albertus Magnus and other subsequent alchemical apologists of the thirteenth-century make this argument. Albertus treats Avicenna's purely rationally intended species as form, materially inherent in the individual metal. "Albert's interpretation would have the effect of turning Avicenna's discussion of genera and species into an argument about matter and form." Newman also mentions the similar factor of the four elements of earth, water, air and fire, and their combinations of the four primary qualities, hot, cold, wet, and dry. ${ }^{122}$

In fact, Aristotle's hylomorphic approach to nature was essential to the medieval understanding of alchemical transmutation, and similarly to Ripley's. The hylomorphic understanding of nature gave all material entities a common "ground," namely "hyle," or what alchemists called the "prima materia." It enabled alchemists to claim that the piece of metal "dies" when regressed to the prima materia, so that when it is re-formed into a new species, it is God who is really doing that, with the alchemist as his agent, only artificially providing the necessary conditions for the transmutation. The artist was only arranging the conditions congenial to transmutation, and thus occasioning it, an act that was temporal and arbitrary. But his role of temporally occasioning the transmutation

\footnotetext{
${ }^{121}$ Lynn Thorndike, A History of Magic and Experimental Science, Vol. II (New York: Columbia University Press, 1923), 158. Thorndike points out that in De Mineralibus III, i.4-9 Albertus argues that Avicenna was only placing a condition on transmutation, saying that it is impossible unless the piece of metal is returned to its prima materia.

${ }^{122}$ William R. Newman “Technology and Alchemical debate," Isis 80.3 (Sep. 1989): 423-445, 430, 436.
} 
shifts the emphasis from the spatial, temporal and artificially induced arrangement "out there" to the intentionality of the artist. While his hands connected the artist with material nature, it is his intentionality that connected him with God. He was thus connected with both matter, which is pure potentiality, and antecedent even to sensible perception, and with God beyond rational perception. His temporal activity was a result of his motivation, and was meaningful in terms of the way it related to this motivation. The centrality of the artist's motivation to the alchemical operation explains the traditional requirement that the alchemist be spiritually and morally clean, so that his intentionality for the highest Good would not be obstructed by base desires such as greed.

In turn, the distinction of the species of material things in terms of the proportionality of the four elements in their constitution, enabled alchemists to claim a hierarchy of metals in terms of the perfection of their elemental proportions, with gold and diamond, as possessing the most perfect proportions, akin to the perfect constitution of the stars in the highest circles of the heavens. Furthermore, alchemists had a universal measure for perfect proportions, namely the Pythagorean "golden ratio" and Aristotelian "golden mean" which transcended the sum total of its parts, and far from merely occupied a flatly measured middle point between them. Finally - the culminating factor in alchemical transmutation - the theory of perfect proportions came to apply not only to material quality but to spiritual quality as well. Spiritual health required the perfect proportions of the "golden mean" just as well as did physical health, and when those proportions were present, both kinds of health were present as well. Transmutation, thus, came to carry physical and spiritual value simultaneously.

What does all this have to do with Ripley's "kind begets kind"? First, it made the "begetting" impossible without a passage of the stone through "death," since only 
through death could the Stone pass into contact with God and through his power be "reborn" or more accurately "resurrected." So,

Kill thou the quick the dead revive;

Make trinitie unitie without any strive. (I, 10.6-7)

For bodies els may not be altred naturally,

Sith Christ doth witnes, without the graine of wheate

Dye in the ground, encrease maist thou none get.

2. And in likewise without the matter putrifie,

It may in no wise truly be alterate,.... (V, 1.5 - 2.2)

The metaphor of the seed is of primary importance in Ripley's Compound, as it in medieval alchemy in general. The Ancient Greek hyle which found its echo in the JudeoChristian primal chaos, and which St. Augustine insisted was created out of nothing by God, rather than having pre-existed creation as in Ancient Greek philosophy, potentially contained the form of the trinity, the likeness of God, as "seeds." Second, since transmutation involved a "resurrection," it could only be accomplished by God. Through these seeds which God planted in the potentiality of the "globous matter and darke under confusion" (Preface, 6.2), God's Word was made present. When the alchemist's base stone was regressed to this primal chaos, it became the seed and found God's Word hidden within it. It is through this Word, hidden in these seeds of primal chaos, that the stone revived and was perfected. "Heaven and earth," says Ripley, "were perfected by his word" (Preface, 6.7). Therefore, when the alchemist regressed the stone to its prima materia, it was God who caused the transmutation. Transmutation, if it was to succeed, had to involve the stone's "marriage" to God, as Virgin Mary married the Holy Spirit. This is not a marriage of kind to kind in the normal sense. Since the stone was reborn and perfected by God through His Word, the alchemical "Artist," who artificially triggered the transmutation, was an agent of God's, as discussed above in connection 
with the 'tailpiece' verses of the Ripley Scroll's British Library MS Add. 5025-4. The temporal arbitrariness of the alchemist's activity in arranging the conditions that would trigger the operation, was an essential condition for the alchemist's freedom of will. It shifted the emphasis from the external activity to the motivation, within the artist, to labor to trigger and nurse the transmutation of his "Stone." Third, the reborn and redeemed "Stone" was different from its former and unredeemed self in a way that surpassed being measured or even understood in terms of that old self's mode of perception, just as the natural mode of knowledge cannot comprehend the life and mode of perception of those who have passed from this world into God's hands. Fourth, and finally, the "begetting" of the "Stone" involves a change in ontological mode, and its accompanying mode of knowledge. In the phrase "kind begets kind," the second "kind" refers to another mode of being and knowledge from that to which the first "kind" refers.

Secretly, therefore, the oft repeated "kind begets kind" sort of phrase has to do with the distinctions between the ontological parts of existence. If like begets like, then a deified stone has to be the child of God, and not only of Nature. Giving birth to a child of both man and God similarly requires a union between man and God. Marriage to the divine is a staple of the "alchemical marriage." A simple marriage between an unredeemed earthly creature and its own kind will only beget another similarly unredeemed earthly creature. "Marrying kind to kind" is, therefore, a "wittie" kind of work that needs interpretation. Ripley's reader must join the matter of the text with its spirit, if he is to produce a "well conceaved fruite." The alchemical marriage is more than a physical operation. For Ripley's reader, it is more fundamentally a matter that requires plenty of "wit." 
The identificiation of the alchemical operation with the operation of knowledge can also be found in the original text to which the commonly used alchemical phrase "kind with kind" alludes. This seems to be the oldest extant alchemical text in terms of origin. "Isis the Prophetess to Her Son" is extant in Greek in the eleventh-century Codex Maricanus. It is believed to have originated no later than the $1^{\text {st }}$ c. A.D. and, in turn, to have "certainly been based on older texts." ${ }^{\text {123 }}$ It is a collection of Greek texts and includes Hermetic and occult texts. The oldest, from the $11^{\text {th }}$ c. is Marcianus 299 , housed at the library Marciana in Venice, which von Franz quotes and translates. Two others are extant, Paris 2325 from the thirteenth-century, and Paris 2327 from the fifteenth. ${ }^{124}$ The Codex Marcianus includes a text by the Pre-Socratic philosopher Anaxagoras-towards whom, incidentally, Norton shows deference, in lines I, 77-86 of his Ordinal. Since Codex Marcianus 299 is dated from the $11^{\text {th }}$ c., it would have already been at the library when Ripley, his alchemical mentor, resided in and frequented Italy. We know that John Dee had his own personal copy of at least some of its manuscripts, copied in his own handwriting from the library of San Marcos in Venice during a visit at the court of Duke of Urbino, Guidobaldo II della Rovere in $1563 .{ }^{125}$ Ripley's above mentioned claim that it was in Italy that he gained the alchemical wisdom he had been searching for on the Continent, makes it not unlikely that he has searched the main libraries for alchemical

\footnotetext{
${ }^{123}$ Marie-Louise von Franz, Alchemy: An Introduction to the Symbolism and the Psychology (Toronto: Inner City Books, 1980), based on a series of lectures given in 1959 at the C.G. Jung institute in Zurich), 7, 41, 43. The text from the Codex Marcianus was published by Marcellin Berthelot as "Isis to Horus," in Marcellin Berthelot, Collection des anciens alchimistes grecs, vol. I (Paris: G. Steinheil, 1887-1888), xiii, $1 \mathrm{f}$.

${ }^{124}$ Vincent Bridges and Teresa Burns, "The Little Book of Black Venus -Part Two: Olympic Spirits, the Cult of the Dark Goddess, and the Seal of Ameth," Journal of the Western Mystery Tradition vol. 2, no. 13 (2007): n.2; cf. Vincent Bridges and Teresa Burns, "Olympic Spirits, the Cult of the Dark Goddess, \& the Seal of Ameth" in T. Burns and N. Turner, eds., The Consecrated Little Book of Black Venus attributed to John Dee (Cold Springs, N.Y.: Waning Moon Publications, Ltd., 2007).

${ }^{125}$ The information on John Dee is from Vincent Bridges and Teresa Burns, "The Little Book of Black Venus -Part Two: Olympic Spirits, the Cult of the Dark Goddess, and the Seal of Ameth." For Dee's connection to the library in Venice, Bridges and Burns cite Roberts, RJ, Watson, AG John Dee's Library Catalogue (London: Bibliographical Society, 1990).
} 
texts. He may well have had acquaintance with this Codex at the same library. He not only spent a large part of his life in Italy living in it or frequenting it, but also studied at its universities, and at the same time aggressively searched for alchemical knowledge. Ripley even claims that it was in Italy that he found the alchemical wisdom he had been searching for on the Continent. ${ }^{\mathbf{1 2 6}}$

In the Codex Marcianus, Isis tells the story of how she obtained the secrets of alchemy by setting them as a condition to an angel who wished to lie with her, ${ }^{\mathbf{1 2 7}}$ and she also discloses the knowledge which the angel, Amnaël, consequently imparted to her. Although the extant part of the story, which seems to be incomplete, does not tell us forthrightly whether or not Isis kept her side of the bargain, von Franz argues for the implication that a fundamental union has indeed taken place. "The person who imparts that mystery to the other person fulfills at the same time the mystical union, the sacred marriage" with that person. This marriage, she points out, can be between Isis and the angel, since the angel imparted the knowledge to her, and at the same time between her and her son Horus to whom she is, in turn, imparting that secret knowledge, "because each time the mystery is told the two also become one- that is probably the meaning.,"128 Isis tells Horus she is allowed to impart the knowledge to him "so you my son are me, and I am you":

After he [Amnaël] had pronounced this oath, he made me with this oath promise never to tell the mystery I was now to hear, except to my son, my child, and my closest friend, so you are me, and I am you. ${ }^{129}$

\footnotetext{
${ }^{126}$ Linden, George Ripley's Compound of Alchemy, vii.

${ }^{127}$ Ibid, 46. There are echoes of this story in the book of Enoch, where the fallen angels have sexual intercourse with human women. In alchemical tradition, the fallen angels give the women the secrets of alchemy. See George W. E. Nickelsburg and James C. VanderKam, eds., 1 Enoch: a new translation based on the Hermeneia commentary (Minneapolis : Fortress Press, 2004).

128 Ibid.

${ }^{129}$ Ibid.
} 
Isis is imparting the knowledge to Horus so she and he will be one. Thus, when the knowledge one receives is divine, one also achieves a union with the source of this knowledge, God. In the following passage which von Franz quotes in English translation, Isis repeats to Horus the sacred truth, or part of it, that the Angel Amnaël imparted to her (the text inserted between brackets being von Franz's own comments):

Now you go and watch and ask Acheron the peasant. [A variation gives Acharontos....] Come and look, and ask the peasant Acharontos, and learn from him who is the sower, who is the harvester, and learn that he who sows barley will also harvest barley and he who sows wheat will also harvest wheat. Now my child, or my son, you have heard that as an introduction, and now realize from that that this is the whole creation and the whole process of coming into being, and know that a man is only able to produce a man, and a lion a lion, and a dog a dog, and if something happens contrary to nature [probably meaning contrary to this law], then it is a miracle and cannot continue to exist, because nature enjoys nature, and nature overcomes nature. [That is the famous saying which also appears in many other texts, but usually as: "Nature enjoys nature, nature impregnates nature, and nature overcomes nature."] Having part of the divine power and being happy about its divine presence, I will now also answer their questions about sands, which one does not prepare from other substances, for one must stay with existing nature and the matter one has in hand in order to prepare things. Just as I said before, wheat creates wheat, and a man begets a man, and thus also gold will harvest gold, like produces like. Now I have manifested the mystery to you. ${ }^{\mathbf{1 3 0}}$

In her own words, Isis now feels she has "part of the divine power and being happy about its divine presence." By receiving divine knowledge she has achieved a union with divine Being. There are two important implications in her speech: First, "nature enjoys nature," and "nature overcomes nature" appear to mean the male enjoys and overcomes the female. But a reader who is "philosophically" aware would notice that the phrase does not have to refer to things of the same epistemological mode, as would the false philosophers understand due to their inability to rise above their immersion in a sensible and absolutized mode. These statements can refer to things of ontologically or

\footnotetext{
${ }^{130}$ Von Franz, Alchemy: An Introduction to the Symbolism and the Psychology, 46-47, quoting from the Codex Marcianus housed at the Marciana library in Venice. The translation from Greek is her own.
} 
epistemologically different natures. Second, those different natures, including the divine, are part of that "one thing," which is the Stone, and which receives divine truth through that in-built link, the likeness which He has enclosed within it. Thus "one does not prepare [sands] from other substances" but from the "matter one has in hand." On the surface, the last sentence seems to merely caution against adding other substances to the "sand," with "sand" presumably referring to a secret ingredient that the listener or reader would only know if he had access to the secret code. The "philosophical" referent of "sand," however, is the "seeds" of the prima materia, which are inherently in the likeness of the Neo-Platonic "One," from whom all emanate and to whom they return. In the medieval narrative of alchemical transmutation, the stone finds God from within itself, as it becomes the seed of God's likeness, when it is regressed. The "Stone" which has "grown" from the "seed" or "sand," contains all the ingredients necessary for its transmutation, within its own being. The epistemologically different natures are all inherent in it, and it can be internally "separated" into its component ontological partsas in Ripley's third Gate "Of Separation"-which follows his second Gate "Of Dissolution."

The text of "Isis the Prophetess to her Son" was important to alchemists. The parts regarding the idea of "like begets like" and those on "Nature" in relation to "Nature," were extensively quoted or alluded to. That part is quoted, and rather elaborated, for example, in the major alchemical text of the Turba Philosophorum, ${ }^{\mathbf{1 3 1}}$ a basic text for alchemists, believed to have originated around the ninth-century and to have been translated into Latin before the end of the thirteenth-century. ${ }^{132}$ For another

131 "Eleventh Dictum" in A.E. Waite, ed., and tr., The Turba Philosophorum or Assembly of the Sages (London: George Redway, 1896), 32-37.

132 (1) Ibid., i and ii. Waite describes the Turba as "indisputably the most ancient extant treatise on Alchemy in the Latin tongue" (i). Waite also identifies Zosimus of Panoplis (end $3^{\text {rd }}$ to beg. $4^{\text {th }}$ c. AD) as an 
example, we know that John Dee (1527-1608 or 09) had a copy of the Codex Marcianus ${ }^{\mathbf{1 3 3}}$ (as well as Ripley's Compound, incidentally ${ }^{\mathbf{1 3 4}}$ ) "during the time he and Kelley were on the continent." ${ }^{, 135}$ Nevertheless critics and commentators have largely ignored the significance of these much quoted phrases and statements. Theresa Burns gives it recognition in her discussion of Edward Kelley's poem "Sr. E. K. concerning the Philosophers Stone, written to his especiall good friend G. S. Cent" ${ }^{\prime 136}$ :

This complex alchemical notion of Nature is often referred to but rarely explained, .... such explanations have been simply footnoted and left for the reader's own exploration. Yet unless one takes time to really ponder what is meant by "Nature begets Nature," Kelley's reference to his friend as "Nature's sower" won't be grasped at all. ${ }^{137}$

Burns connects Kelley's “ecstatic notion of 'Nature' begetting 'Nature' and sowing the harvest of the Philosopher's Stone" with the phrase "“Nature's sower" in the second line

important influence on the Turba (iii). Zosimos of Panoplis' works were seminal for the alchemical literary tradition and some of its main symbols, such as the "Sun" and "Moon." Zosimos' richly illustrated Book of Pictures (Mushaf as-Suwar), has been made available by Theodore Abt in as part of the Corpus Alchemicum Arabicum project: Theodore Abt, ed., The Book of Pictures [Mushaf As-Suwar] by Zosimos of Panoplis, Corpus Alchemicau Arabicum vol. II.2, tr. Theodore Abt and Salwa Fuad (Zurich: Living Human Heritage Publications, 2011).

(2) For the date of the Turba's composition in Arabic around the $9^{\text {th }}$ c. (by an author who lived in Panoplis, the same city to which Zosimos belonged), see M. Plessner, "The Place of the Turba Philosophorum in the Development of Alchemy," Isis, Vol. 45, No. 4 (Dec., 1954): 331-338.

(3) For the date of the translation of theTurba Philosophorum, 12th to $13^{\text {th }}$ c., see A. Y. Al-Hassan, "The Arabic Origin of Jabir's Latin Works: A New Light on the Geber Question," Journal for the History of Arabic Science, Vol. 10, Numbers 1 \& 2, Aleppo: Institute for the History of Arabic Science (1994), 5-11. Most of this article appeared also in. A. Y. al-Hassan et al, eds., The Different Aspects of Islamic Culture Science and Technology in Islam, vol. IV, Part II, UNESCO (2002), http://www.history-sciencetechnology.com/articles/articles\%204.htm\#*, accessed Jan. 29 ${ }^{\text {th }}, 2013$.

${ }^{133}$ Vincent Bridges and Teresa Burns, "The Little Book of Black Venus -Part Two: Olympic Spirits, the Cult of the Dark Goddess, and the Seal of Ameth," Journal of the Western Mystery Tradition vol. 2., no. $13,2007$.

${ }^{134}$ For the importance of Ripley's Compound to John Dee and Edward Kelley see Jennifer M. Rampling, "John Dee and the alchemists: Practising [sic] and promoting English alchemy."

${ }^{135}$ Teresa Burns, "Concerning Ed. Kelley's Poem," Journal of the Western Mystery Tradition vol. 2 no. 15 (Autumnal Equinox 2008), n.p. Burns refers to V. Bridges, and T. Burns, "Olympic Spirits, the Cult of the Dark Goddess, \& the Seal of Ameth" in The Consecrated Little Book of Black Venus attributed to John Dee, ed. T. Burns and N. Turner (Cold Springs, N.Y.: Waning Moon Publications, Ltd., 2007). Burns notes that an earlier draft of the latter article is available at http://jwmt.org/v2n13/book.html , 209-210 n 152-153. She also refers to A. Klein, ed. and tr., Die Monas-Hieroglyphe von John Dee aus London (Interlaken, Switzerland: Ansata-Verlag, 1982), 124-126, 130-132, http://www.jwmt.org/v2n15/garland.html.

${ }^{136}$ Linden, George Ripley's Compound of Alchemy Compound, 12.

${ }^{137}$ Burns, "Concerning Ed. Kelley’s Poem," n.p. 
of the mentioned poem, and infers that "Kelley is here telling his friend G.S. [whom she argues may be Shakespeare] that the friend could become, like Isis or her son Horus, the begetter of the magical secrets of 'Nature'."138 She treats the seed as a generic "balance point" as in Janus with the two heads, locating the point where endings are transformed into beginnings. She does not, however, address the problem of how 'like begets like' is related to the fact that the alchemist seeks to transmute his stone into another species. Of course, it is important to recognize that 'like begets like' does indeed assert the need to respect the internal laws of each species or genus, and the laws of nature in general. It also tells us that transmutation does not break the laws of nature but works with and through them. At the same time, however, in the ancient Egyptian tradition which forms the cultural background to the story of Isis, the sacred art of alchemy was used to mummify and permanently preserve the body of the dead pharaoh, which he will use when his boat-of-the-dead reaches the deepest point of the underworld, and rise through that deepest point, which is the enigmatic and peripetetic "balance point," into the divine realm and a new life, this time deified and eternal. Significantly, "the boat and its ferryman Acharontos" are one of the enigmatic entities which Amnaël "conjures" to bind the oath between him and Isis before imparting the sacred knowledge to her. ${ }^{139}$ The "balance point" is not one between an end and a beginning of elements within the same epistemological network, but one at the paradoxical core of a switch from a term belonging to one network into a term belonging to another network. The network of signifiers, in each epistemological mode, has to be collected together and its mode recognized, before the transition between modes can occur. It is about this categorization

\footnotetext{
${ }^{138}$ Ibid.

${ }^{139}$ Von Franz, p. 46.
} 
which gathers each epistemological network together and distinguishes the networks from each other that the Turba's "Parmenides" speaks when he says:

Know ye, further, that unless ye rule the Nature of Truth, and harmonize well together its complexions and compositions, the consanguineous with the consanguineous, and the first with the first, ye act improperly and effect nothing, because natures will meet their natures, follow them, and rejoice. $^{\mathbf{1 4 0}}$

When the "consanguineous" constituents or "natures" of truth are collected together, then switching from one "like" to another "like" involves a switch between entire networks, and a passage between them that is enigmatic. At the same time, the one network, or "nature" does not contradict or violate the other. The Pharaoh would still be human, and his transmutation would not have broken the laws of nature. But he would also have become divine, and would have transcended those laws, and transformed them by incorporating them into the structure of the divine nature and its 'laws'. Thus the Turba's "Parmenides" continues the same speech quoted above in terms directly suggestive of the enigmatic passage through death between one "nature" and the next, but also suggestive of the exaltation to which this passage leads:

because natures will meet their natures, follow them, and rejoice. For in them they putrefy and are generated, because Nature is ruled by Nature, which destroys it, turns it into dust, reduces to nothing, and finally herself renews it, repeats, and frequently produces the same. Therefore look in books, that ye may know the Nature of Truth, what putrefies it and what renews, what savour it possesses, what neighbours it naturally has, and how they love each other, how also after love enmity and corruption intervene, and how these natures should be united one to another and made at peace, until they become gentle in the fire in similar fashion. Having, therefore, noticed the facts in this Art, set your hands to the work. If indeed, ye know not the Natures of Truth, do not approach the work, since there will follow nothing but harm, disaster, and sadness. Consider, therefore, the teaching of the Wise, how they have declared the whole work in this saying: Nature rejoices in Nature, and Nature contains Nature. $^{141}$

140 A. E. Waite, Turba, "Eleventh Dictum," 32.

${ }^{141}$ Ibid., 32-33. 
"Nature contains Nature" says Turba's "Parmenides." Nature "in" nature "putrifie[s]" and is "regenerated." The containing nature "destroys [the contained], turns it into dust, reduces to nothing," before it "finally herself renews it." The limited and contained natures (which can be understood as female sensible, and male rational, knowledge) are "neighbours," and they love one another. But "after love enmity and corruption intervene." It is the work of the alchemist to re-establish peace between them. The corruption and war between them might not be recognized under a false appearance. But when the alchemist regresses his base stone to its prime matter, the false appearance will no longer abide, and its external identity will disintegrate. The stone which has been regressed to the primal chaos, which has "died," has re-connected with divine being, become the seed and regained the potential order among the constituent natures of "Truth," from thence it can rise-through specific stages - into its regenerated, perfected and deified form:

"O those celestial natures, multiplying the natures of truth by the will of God! O that potent Nature, which overcame and conquered natures, and caused its natures to rejoice and be glad! ${ }^{\mathbf{1 4 2}}$

"Parmenides" seems to be referring here to the multiplication of the Stone that occurs after it has been perfected, and has acquired the ability to turn others into gold like itself. If this is so, then the "celestial natures" might refer to the resulting stones in whose being the "natures" of "Truth" are properly recognizable and in order among each other. In each stone, the constituent "natures" of "Truth" will be part of "that potent Nature, which overcame and conquered natures, and caused its natures to rejoice and be glad!" The lower natures are ruled by the higher Nature which generates them.

\footnotetext{
${ }^{142}$ Ibid, 35 .
} 
The text through which Isis imparts the hidden and divine knowledge to her son Horus shares a fundamental feature with the text through which Ripley imparts similarly divine and hidden knowledge to his pupil whom he too calls his "Child" (Prol., 1.1). Both hide their intended meaning beneath the apparent context of 'normal' discourse. Isis' statement that a "miracle" against the laws of nature "cannot continue to exist" is true of the kind of nature we know sensibly, which is only one part of the truth. But the complete truth contains other natures, and when they are united together in the perfect allegory, the meaning of the statement is "transmuted." The truth that the "miracle" "cannot continue to exist," apophatically refers to another part, a part missing and hidden beneath the first part's common-sounding discourse, and one which states that it can, and the way in which it can. This hidden part of the truth, however, does not mean that the laws of that kind of nature we know in the sensible mode are annulled. On the contrary, the stone will die. But its death is part of a peripetia through which death will be life, and a redeemed form of life. The passage through death will continue to be part of the whole, just as Christ's passage through death will continue to be part of his eternal life. Within this dynamic whole, death is not a 'state,' infinite absolute and tyrannical, but an event. Death is part of the constituents of the perfected being of the Stone as the peripetetic passage between each ontological sphere and the next. Alternately, it is also a passage between each epistemological mode and the next in the active constitution of the living allegory of the Stone. By transforming death from an incommensurable and impassable infinity into an event, and incorporating it into its structure, the Stone will have become a living and dynamic microcosm which does not die, as many fires as it may be subjected to. It has already incorporated the passage through fire in its being. The event of reversal or "peripetia" through Death, between each epistemological mode and the next, is not only 
a firm part of its being, but a part that strengthens and binds it together, as in the Homeric golden chain, or "chain of love" that Theseus describes towards the end of Chaucer's Knight's Tale. The passage through death is enabled by God's love. The perennial cycle of physical life and death, which erases the individual identity of nature's creatures, cannot affect it. It will have become God's creature and not only nature's. Thus nature, in Isis' words, will "overcome" nature, and in Parmenides' words, "Nature contains Nature.”

Both the text of "Isis the Prophetess" and that of the Compound endow their text with textual mechanics that 'imitate' the "Nature of Truth," and by imitating, guide the authentic reader into a spiritual recognition which will raise the reader's mind to a higher awareness. Understanding the text involves a formal or ontological event: a reversal from the habitually expected semantic mode of knowledge to an epistemological one. This reversal involves the mind's sudden act of collecting the entire mode of semantic, or sensible, knowledge into a category, and thus rising to a new freedom from that previously totalized category's tyranny. The same applies to the rational mode of knowledge. Categorization indicates the mind's ability to rise above the entity that is categorized, regardless of its logical infinity.

In the reversal of expectation that accompanies this recognition, the text of the Compound comes to life in its words' newly revealed ontological rather than semantic differentiation - as we shall further see below-bringing into view the various selfcontained networks of meaning to which these various terms independently belong. In this sense, the words acquire a Boethian "plenitude." It is the reader's acts of perception, and as such of knowledge, that brings these self-contained epistemological networks into relation with each other- a relation which the reader can subsequently contemplate and 
examine. Once the reader raises his mind above immersion in an absolutized mode of perception and purposefulness, he will be able to 'transmute' the text of his own mind in terms of the way that it "knows." By rising above the various epistemological categories, the mind will have acquired a likeness to the divine Intellect which can collect them together simultaneously.

A transmuted mind has a transmuted goal. As the reader's mind learns to interpret, the sort of "Philosopher's Stone" he is looking for "in" the text, is also transmuted. He learns to look, not for a merely sensible kernel, or an abstract one-a new term to substitute for an old term — but for a truth that exceeds both sensible and rational epistemological modes, and their collective total. The mind's method of interpretation acquires wisdom. The reader's goal is to discover the "Philosopher's Stone," and through his exercise of the correct form of interpretation, he has come to "know" the "Stone." $\mathrm{He}$ recognizes that his "Stone" is begotten by Nature, Man and God at once, as in the 'tailpiece' verses of MS Add. 5025-4. The "Stone" is a Christ-figure, but with the difference that Man is its mediator through his art- in this case, his text, which is also his mind.

Interpretation, therefore, is an essential activity of the operation of knowledge. But if it is to be successful and truly produce meaning, it cannot be limited to the world of sensible or even merely rational knowledge. In the poetic piece entitled "An Admonition, wherein the Author declareth his erronious Experiment," which Linden includes in the after-matter of his edition of the Compound, Ripley's language hints that there is only one kind of transmutation that does succeed, and this is of the textual (and thus also spiritual) kind. In it he describes his failed past pursuit of the material sort of transmutation: 
8. Manie an amalgam did I make, Weening to fixe them to great availe, And thereto Sulphure did I take, Tartar, egges, whites, and oyle of the snayle, But ever of my purpose did I faile, For what for the more, and what for the las, Evermore something wanting there was. (8.1-7)

10. Thus I rosted and broyled, as one of Gebers cookes, Oft times in the asshes my winning I sought, For I was deceived by manie false bookes, Whereby untruth truly I wrought (10.1-4)

The medley of images from the material world - "Tartar, egges, whites. and oyle of snayle"- together with the caricaturish images from the scene of practical human activity — "rost[ing] and broil[ing], as one of Gebers cookes"—emphasizes materiality and blindly busy bodily praxis, impelled by passionate desire. Intellectual activity is palpably absent, "whereby untruth" was the only truth "truly I wrought." Ripley also invests allegoresis — understanding correctly—with a moral and epistemological dimension. If the reader does not read truthfully, like the "fooles" who "haunt" "Westminster Kerke," (V, 27.1) he will produce falsehood. He specifies text-“false books"- as the vehicle through which he was misguided, and singles out "untruth" as its product.

This investigation of the Compound's way of meaning indicates that Ripley's rejection of material alchemy in "Erroneous Experiments" was already implied in the Compound and not a new development that belatedly arose after he had written it. Ripley wrote the Compound relatively late in life, after he had returned from his travels and settled back in England, at the Augustinian priory in Bridlington. The kind of praxis that the verses of "Erroneous Experiments" describe and reject, one engulfed in material reality and unable to rise above it, is the subject matter of 30 (from 21 till 50) of the 51 
stanzas of the unusually long fifth Gate, notably "Of Putrifaction." In the fifth Gate, Ripley makes the transition from stanza 20 to the beginning of that long tirade at stanza 21, by suggesting the contrast between knowledge of "truth," which is divinely inspired, with "fansies":

Therefore if God vouchsafe thee to inspire, To know the truth, and fansies to eschew Like unto thee in riches shall be but few. (V, 20.5-7)

The riches he promises his pupil do not have to be material, though they would include the idea that he would not be losing his money by working "after [his] fantasie." Ripley implies that "To know the truth" arises from divine inspiration. The false philosophers, who have no divine inspiration, "worke after their fantasie." They divide the "white and red" "manually," and "to sight":

21. But many men be moov'd to worke after their fantasie, In many subjects in which be tinctures gay:

Both white and red divided manually

To sight, but in the fire they flye away:

Such breake pottes and glasses day by day,

Enpoysoning themselves and loosing their sights,

With odours, smoakes, and watching up by nights (V, 21.1-7)

Stanza 21 clearly emphasizes physicality and bodily praxis, free of spirituality. Men who limit their vision and purpose to "fantasies" can only end up with a stone that "flies" apart under the test by fire. It is emphatically physical, causing pots and glasses to break, poisoning, blinding, and emitting odors and smoke. This emphasis on physicality and manual praxis is generally dispersed throughout the thirty stanzas of the tirade, as we have in part shown earlier. Ripley's false philosophers are clearly reminiscent of Chaucer's Canon, with their thread-bare clothes and bleary eyes:

22. Their clothes be baudy and worne thread bare, Men may them smell for multipliers where they goe, 
To file their fingers with corosives they doo not spare,

Their eyes be bleard, their cheekes leane and blowe, (V, 20.5 - 22.4)

In contrast to the physical praxis, the "one" alchemical operation that is "true work," at which Ripley hints towards the end of the "Admonition," involves the language of verbal and textual activity, "Treatise," "telling" "studie," "writing" and "Trust to my doctrine":

12. I sawe never true worke truly but one,

Of which in this Treatise the truth I have told:

Studie only therefore how to make our Stone,

For thereby maist thou winne both silver and gold,

Upon my writing therefore, to ground thee be bold:

So shalt thou loose nought if God be thy guide,

Trust to my doctrine, and thereby abide. (12.1-7)

Ripley advises his pupil to "ground thee" "upon my writing" and let "God be thy guide." The textual implications are undeniably present. By "grounding" himself upon Ripley's "writing," the reader will be able to perform the "true worke" of transmutation. His interpretation of Ripley's text will be redemptive and transformative both of 'meaning' and of the reader himself. While Ripley bars the reader from immersion in a virtual world, he pulls him into another mode of participation that is equally engaging. This he does through keeping the reader "ground[ed]" in the enigmatic and bidirectional moment of learning, in which he has the radically constitutive role of interpreter.

\section{The Four Elements and the Knitting Motif}

After stating, in stanza 12, that "I sawe never true worke truly but one . . .," Ripley's last three stanzas turn to the "true worke," which is "this Treatise" and "our Stone." The last of the three, 15, Ripley commends the reader to God. In stanzas 13 and 14, the language of the Compound self-consciously turns upon itself to become fully selfreflexive. In these three stanzas Ripley produces the metaphor of the myne which hides 
the metals, as a paradigm of interpretation. It presents Man as essentially an interpreter. He is like Hermes, moving between two realms. He is God's art, and like God, he too is an artist:

13. For our mettalls be nought els but our myners two, Of Sunne and Moone, wise Raymond said so. Remember that Man is most noble creature Of earthly composition, that ever God wrought, In whom is the foure Elements, proportioned by natur, A naturall Mercurialitie, which costeth right nought, Out of his myne by arte it is brought;

14. The clearnes of the Moone, and of the Sunne so bright, Into these two myners descendeth secretly, Howbeit the clearnes is hid from thy sight, Which by craft thou shalt make it to appeare openly. (13.1 - 14.4)

In the previous stanzas of "Erroneous Experiments," Ripley was telling his reader not to reduce himself to rags by seeking costly physical material from which to develop his stone. In stanzas 13 and 14, Ripley tells him that the materials he needs are within his being, and cost him nothing. In saying this Ripley is hinting that the operation he is imparting to his pupil is not one that occurs in an actual laboratory, but in the laboratory of his text. To understand these verses, one needs to refer to alchemical symbolism. Perfected Man is androgynous. Within his microcosm, masculine "Sunne" presides over the rational realm, and feminine "Moone," over the sensible realm. "Sunne" and "Moone" are also the self and the beloved other who are constituents of oneself. These two, in the unredeemed individual, are in conflict, the self being divided against itself. The alchemist must establish peace between them, and join them in holy matrimony to form his stone. But to join them successfully, in a union that resists the test by fire and the vicissitudes of temporal life- even death itself-he must redeem them first. If he joins them on the superficial level of unredeemed rationality and sensibility, the one 
merely abstract, the other in a state of isolated pathos, his stone will not last, but break back into its warring pieces when tested. In order for the marriage he brings about between "Sunne" and "Moone" to be successful, the alchemist must pierce through the invisible limits of rationality and sensibility, to their substantial truths 'above' and 'below' reason and sense respectively. After all, the rays that "Sunne" and "Moone," shine into the depths of the earth, where they become hidden, are illumination they have received from God, as Neo-Platonic illuminations which descend through the ontological layers of the universe. These substances of "Sunne" and "Moone," are 'above' normal perception because coming from God, and 'below' normal perception because buried in the bowels of prime matter. Their respective rays are in hiding, unavailable to the natural mind, hidden in the depths of the mine, in the form of "our myners two," (metaphoric) sulphur and mercury (functionally distinct from Mercury, though a part or aspect of his total role). The alchemical poet "mynes" them out of hiddenness "by art." What he "mynes" out of hiddenness is the purely spiritual and ineffable substance of divine truth beyond rational conceptualization, and the purely physical matter - the Medieval "prima materia," and Ancient Greek "hyle"-below sensibility, as pure potentiality, formless matter, and primal chaos. The first involves a sacrificial form of "death" where the end of natural reason meets the beginning of the ineffable and divine intellect. The alchemical artist joins rational precept to the spiritual substance of its truth, a truth in which knowledge and affect are identical, since in God, truth and love, action and passion, are one. Similarly, he joins sensible image to its material substance, lifting that substance into visibility and knowability. Man's "Mercurialitie," is his dynamic being-his active trinitarian, mediating and Christ-like 'soul'—which, like Mercury as 'Hermes,' moves back and forth between the two poles of existence, spirit and matter, heaven and earth, to 
unite them together into the "alchemical marriage" out of which the transcendent Stone is born, simultaneously artificial, natural and divine. Through his art man marries his inner "Sunne" and "Moone" to each other not only in terms of rational species and sensible image — both being the instruments of his art—but also in terms of the very substance of their truth. Through his art Ripley aims to marry them together, and make "earth become all that before was heaven." What he "conjoins" in the sacrament of marriage are the ontological entities of his own being, thus redeeming and re-creating himself "by arte" into a living allegory, the Stone.

Epistemological, rather than semantic, "separation" and "conjunction" of ontological parts is the basis of the way Ripley's language comes to mean. Unless the reader recognizes that, the text of the Compound will not come alive for her. Ripley's "Stone" is not only allegorical. It is the personification of allegory as an entity of meaning, with wholeness and subsistence that no ravages of infinity-no gargoyle of endless fragmentation--can annul. Fragmentation, nonbeing and infinity the perfected Stone will have transformed into an event of death and passage to the other side — and it will have incorporated them into the structure of its being. Ripley's Stone is his "child," his opus and his reader. It is a living microcosm that incorporates the entire ontological structure of reality. It is also Christ and Hermes. Last but not least, it is Ripley himself, who is the "child" of the old fathers, and the "father," in turn, of his pupil. Ideally, Ripley's stone is not only an allegory, but also Allegory itself as a whole. It is a particular living person, and at the same time a universal person, but without losing his particularity. It is also a dynamic embodiment of that person's participatory act of coming into knowledge and being. Ripley's stone is also a personification of an event of collaborative action among individually distinct epistemological modes. These modes are 
themselves little actants - and as such prosopons - contributing together to a larger and unified action which works to build the living Allegory complete with its entire ontological constituents. The prosopons, who are actants personifying the various ontological and epistemological modes, are set into an unfolding, temporal and dynamic interrelationship with each other in a whole that immeasurably exceeds the sum total of its parts.

In the Compound, these prosopons or actants are arranged into sets, each selfenclosed, but engaged in a relationship with the other sets. This structure can perhaps most easily be studied in the third Gate "Of Separation" and the fourth Gate "Of Conjunction." Ripley specifies three ways in which the reader must perform the "separation" and "conjunction": a "diptative" of the male and female to be married, a "triptative" of body, soul and spirit, and a "tetraptive," of the four elements:

6. But manners there be of our Conjunction three, first is called by Philosophers Diptative, The which betwixt the agent and patient must be, Male and female, Mercury, and Sulphure vive, Matter, and forme, thinne, and thick to thrive, This lesson will helpe thee without any doubt, And our Conjunction truly to bring about.

7. The second manner is called Triptative, Which is Conjunction, made of things three, Of bodie, soule and spirit, that they not strive, Which trinitie thou must bring to unitee, For as the soule to the spirite the bond must bee; Right so the bodie the soule to him must knit, Out of thy minde let not this lesson flit.

8. The third manner and also the last of all, Foure Elements together which joyne to abide, Tetraptative certainely Philosophers doe it call, And specially Guido de Montano whose fame goeth wide, And therefore in most laudable maner this tide, In our Conjunction foure Elements must aggregate In due proportion, which first a sunder were seperate. (IV, 6.1 - 8.7) 
In these three stanzas Ripley builds a pyramidal structure of sets of four, three, two, and, in fact, one, which results from the unity of the whole. Each character can have many names, and each set can have several versions. The "diptative" set, for example, is "Male and female, Mercury, and Sulphure vive, / Matter, and forme, thinne, and thick." Although each set is self-enclosed, they are all ultimately reducible to potentiality (female) and action (male), respectively. In the Trinitarian structure, body is passive, soul active and spirit their connection with the divine beyond and their unifier. The four elements range from earth, which is passive, to fire which is action itself. Therefore female and male, or potentiality (passion) and action, run through the entire structure. The Judeo-Christian trinity of soul, body and spirit, Urszula Szulakawska argues, is problematic in the attempt to fit it with the Ancient Greek four elements, ${ }^{\mathbf{1 4 3}}$ but this may depend on interpretation. Earth and water, the one mixed with the other or passing into each other, are body, water with air is spirit, air with fire is soul. At the same time, the four elements are epistemological entities. Earth as matter is prior to perception, but contains the seeds of the operation of knowledge, Water is sensible perception, air is rational perception and fire is divine or spiritual perception beyond sensibility or natural reason.

In teaching the reader to "separate" Ripley uses metaphorical language that conveys to the alert reader, who has begun to gain wisdom, the message that he must do the separation ontologically and not materially. He cautions the reader not to separate his stone "manually," but by the subtle from the gross, which implies the spiritual from the bodily. He speaks of dividing the "subtile from the grosse, the thick from the thinn" in

\footnotetext{
${ }^{143}$ Urszula Szulakowska attribures this the combination of the tetraptive and triptative sets to Ramon Lull's problematic addition of the Christian Trinitarian form of body-soul-spirit to the Aristotelian square of the elements and its scheme of the squaring of the circle. Urszula Szulakowska, "The Pseudo-Lullian Origins of George Ripley's Maps and Routes as developed by Michael Maier," 107-126.
} 
the same breath as he also speaks of dividing the four elements according to their qualities:

1. Seperation doth each part from other divide, The subtile from the grosse, the thick from the thinn But Seperation manuall looke thou set a side, For that pertaines to fooles that little good doth winn, But in our Seperation Nature doth not blinn, Making division of qualities elementall, Into a fift degree till they be turned all. (III, 1.1-7)

And Seperation is called by Philosophers definition, Of the saide foure elements tetraptative dispersion. 3. Of this Seperation I finde a like figure, Thus spoken by the Prophet in the Psalmodie, ${ }^{144}$ God brought out of a stone a flood of water pure, And out of the hardest rock oyle abundantly, ${ }^{145}$ So out of our stone precious if thou be witty, Oyle incombustable, and water thou shalt draw, And there abouts at the coale thou needst not to blow. (III, 2.6 - 3.7)

Manual separation is a division or cutting of the material of the stone into inorganic parts. That would merely be a division of the thing into smaller parts, such as one would a log of wood into smaller pieces of wood. This kind of separation "pertaines to fooles," and, as shown above, Ripley defines fools as those who misconstrue the meaning of his words, or, in other words, who do not know how to perform allegoresis correctly. He has also told us that we must perform our operation philosophically. Now he also adds that it is Nature that performs the separation, and "doth not blinn." The division, then, is a different kind of action from dividing things into parts that are merely more things. That cannot help in transforming them. We very well know what Nature separates. It separates that part of the person which is responsible for his agency as actant, from the material substance of his body at death, and in doing that it does not "blinn." Such separation, like

\footnotetext{
${ }^{144}$ Linden notes that the analogy here is to "David's praise of God for providing water from the rock in the wilderness (Psalms 78:15-16, 20; 105: 41)." Linden, George Ripley's Compound of Alchemy, p. 116.

${ }^{145}$ Ibid., "Deut. 32:13, Moses' song of praise to God reads in part, 'he made him to suck honey out of the rock, and oil out of the flinty rock."”
} 
the subsequent alchemical re-conjunction, is also philosophical, since when Nature separates, our mind distinguishes and categorizes those entities. The element of Fire as act, and of Earth as Hyle, are the extremes of action and passion. By loosening the creature's ontological parts from each other, Nature makes this creature's inherent constituents perceivable. The soul that separates from the body would rise to join the spirit. This triad of body soul and spirit, the alchemical process aims to bring back into a new union that is more authentic and lasting, having incorporated death and transcended it. The resulting entity will be the resurrected being, or 'stone,' now perfected in its triadic likeness to the divine Trinity. Like God the Father whose act of Creation is His substance, the Stone $i s$ substantially its collaborative self-constituting act, through which it has participated in the Father's act of its own creation. The Father, Who is pure act, is also the substance from Whom all creation emanates. The Holy Spirit Who is both Love and Understanding, is as such the one who provides the motivation for the reditus back to the Father, and the Son is the soul and mediator between the divine and human trinity, and through whom both exitus and reditus are effected.

In the "tetraptive" set, the four elements are arranged according to the epistemological modes involved in the operation of knowledge. An unsuspecting reader would think that in the last line (3.7), Ripley is simply instructing the alchemist that he not blow the coals at this stage of the operation in the laboratory. But Ripley is really telling his initiate that at physical as opposed to 'philosophical' "coale thou needest not to blow." "If thou be witty" (3.5) is the hint Ripley has planted at this location as a hint to the reader to interpret, and to do that "philosophically." The separation of the four elements, which separation Philosophers call "tetraptive dispersion," Ripley explains, is similar to God's pulling water and oil out of stones and rocks: Significantly, "Oil" in 
alchemy is generally "soul," the union of air with fire, and water is spirit in its form when united with air. It implies God creates life even out of hard rock, and functions as an analogy to the alchemist's abstracting the elements from the gross to the subtle during the circulation of the elements from earth to water to air then fire.

Hidden within the text are the "seeds," or liminal sparks of the originary movings of the reader's intentionality - the originary beginnings of motivation that launch the reader into the hermeneutic journey in quest of truth. The text triggers interpretationwhich is the "separation" of the textual elements-since without separation the reader will not have the clarity of mind or awareness to re-conjoin his elements well. The text of the Compound substantially consists of the reader's soul in so far as soul is intentional and seeking action. The "separation" involves the reader's coming to an awareness of the ontological parts of his being, and the "conjunction" which follows is the soul's mediating action of "knitting" the spiritual and corporeal modes together:

1. After the Chapiter of naturall Seperation, By which the elements of our stone dissevered be, The chapter here followeth of secret Conjunction, Which Natures repugnant joyneth to perfect unitie, And so them knitteth that none from others may flie, When they by fire shalbe examinate, They be together so surely conjungate.

2. And therefore Philosophers give this definition Saying this Conjunction is nothing els But of dissevered qualities a copulation, Or of principles a co equation as others tells:

But some men with Mercurie that Pothecaries sells Medleth bodies, which cannot divide Their matter, and therefore they slip aside.

3. For until the time the soule be seperate And cleansed from his originall sinne With the water, and throughly spiritualizate, The true Conjunction maist thou never begin: Therefore the soule first from the bodie twyne, Then of the corporall part and of the spirituall. 
The soule shall cause conjunction perpetuall. (IV, $1.1-$ 3.7)

While in these lines Ripley does not tell us directly that the operation is textual, he makes it clear that the "dissevered qualities" and "principles" which "Philosophers" conjoin or "copulate," are not the physical materials that men buy from apothecaries. The stone is dissevered into "elements" but not "manually." It is the kind of separation that severs soul from body. It is, in other words, undeniably a separation of the stone into its constitutive ontological entities. Unlike the subsequently mentioned conjoining that false philosophers make, which cannot withstand the test by fire, the "true Conjunction" withstands that test and is "perpetuall."

In this transformative operation, Ripley gives the soul the active role or, in Aristotelian and scholastic terms, the role of the "agent." Among the personified parts that are to be conjoined in the "alchemical marriage," it is the soul that "shall cause [the] conjunction perpetuall." Like Hermes, it goes back and forth between body and spirit, the natural and the divine, and "knitteth" them together: "so them knitteth that none from others may flie" (1.5). In instructing the reader how to join the "triptative" of body soul and spirit together, Ripley puts the soul in the middle, again using the metaphor of knitting:

For as the soule to the spirite the bond must bee;

Right so the bodie the soule to him must knit, (IV, 7.5-6)

As emblematically represented in the Rosarium Philosophorum, and as the "Ripley Scroll" suggests, the product of the "knitting" will be a Christ-figure, a physically embodied God-Man, in whom the human word has become part of the divine Word.

The metaphor of knitting expresses the way the conjunction is both ontological and textual, essentially involving language, and the operation of knowledge. The soul's 
knitting activity is similar to the emblematic soul's emblematically represented in the Rosarium Philosophorum. The soul's Hermes-like activity as mediator going back and forth between body and spirit, or heaven and earth, in the Rosarium Philosophorum, has already been mentioned above. But in order to clarify the epistemological nature of the knitting, it should be noted that the Rosarium Philosophorum differentiates between the male soul and the female soul (the two are meant to be part of a single soul, since the man and woman being married are part of the same person, and since the soul itself is internally trinitarian, just as at the same time it is itself one part of the same trinity of body, soul and spirit as well). The Rosarium depicts two consecutive cycles in which the soul leaves the androgynous body ascending to heaven, where it unites with the "water" of heaven, depicted as cloud, and descends back again to revivify it. This Hermes-like motion of the soul, whether one considers it occurring within the soul or outside of it, implies in both cycles that it is the agent of the action of bringing heaven and earth together. In the first cycle the soul that ascends into the clouds from the dead hermaphroditic body of the couple being married, is male, which would be associated with the rational activity of the soul. In the second cycle, it is female, which would be associated with the sensible and affective activity of the soul. In both cycles, the ascent of the soul triggers the fall of dew from heaven, first through the soul's rational activity, and then, through its sensible activity. The body of the hermaphrodite comes back to life at the end of each cycle. After the first cycle it is depicted as a rebus - a hermaphroditic person with two heads, those of male action (soul) with female passion (spirit), attached to a single body. After the second cycle it is depicted first as "rebus," then as a hermaphroditic and internally fecund Virgin, with Father and Son on either side, and Holy Spirit above--implying that the Virgin is also a triadic union of the three--and 
finally as Christ the "Philosopher's Stone," presumably risen phoenix-like, out of its parent's ashes. The Christ figure is depicted rising out of the sepulcher in which the dead hermaphroditic body had lain.

While the soul's visual knitting of heaven and earth in the Rosarium by means of the soul's ascending and descending, would have been familiar to those interested in alchemy, the metaphorical use of the English word 'knitting' would have been familiar to the medieval reader in general and George Ripley in particular. Chaucer frequently uses it in his translation of Boethius' Consolation of Philosophy. In his Boece, Chaucer, whom Ripley admired and sought to emulate, uses the word "knytt" in its grammatical variations around sixteen times, in addition to a single use of the word "weve" ('weave') (IV, p.6 ). The Consolation was perhaps the most consistently and commonly read book of the Middle Ages through a span that exceeded a millenium from the date of its composition (ca. 524) up to the end of the Middle Ages. Considering Ripley's Chaucerianism, ${ }^{\mathbf{1 4 6}}$ it is unlikely for Ripley not to have been familiar with it in its Chuacerian rendition. In Chaucer's Boece, "knytt" occurs in the context of joining together ontological entities, or joining together epistemologically different verbal or textual elements. The image of knitting or weaving has a significant advantage over the more abstract idea of 'uniting', or even the rather vague 'joining'. Knitting, as weaving, joins things together into constituents of a single and unified entity, but without destroying the distinctness and internal autonomy of the particular entities, such as the threads, it may join. Ripley emphasizes it:

Loosing and knitting thereof be principles two Of this hard science, and poles most principall; (IV, 15.1-2)

\footnotetext{
${ }^{146}$ See p. 64 in this document.
} 
An instance of reference to textual knitting occurs in Boece's phrase concerning men who try to "unknytten the knotte of this questioun" (V, p.3.29-30). Similarly Boece invites Lady Philosophy, whom Chaucer names "Philosophie," to resume her explanation by asking her to "Knyt forth the remnaunt" of her speech (IV, P.2.111), speech through which she is teaching him wisdom. In the ontological sense of the metaphor, Boece addresses God as "thou ... that knyttest alle boundes of thynges." Another use of knitting in its ontological sense of uniting ontological entities, occurs in the reference to the "treble kynde" of the soul: "Thow knyttest togidere the mene soule of treble kynde" (III, m.9, 24-26). In Boece, as in both Christian and alchemical doctrine, and as in Ripley in particular - who combines both - the soul is formed into the trinitarian likeness of God, and this internal trinitarian form is simultaneously re-produced in its external relationship with body and spirit. When the soul knits body and spirit together, it is in effect participating with God in creating itself. While the soul is an ontological entity, its fundamental and self-constitutive action is the operation of knowledge. Since the ontological structure of the universe is constituted by the participatory and creative operation of knowledge, the "knitting" action is an operation that simultaneously both epistemologically and ontologically constitutive.

Examples of the occurrence of simultaneously ontological and epistemological 'knitting' abound in Boece. Regarding the definition of "hap" or event, for example, Philosophie contrasts men's foolish understanding of events and their causes as "foolish moevynge," or in other words as limited to the single epistemological mode of the sensible world, against what she calls the "knytting of causes." In her phrase "knytting of causes," she is referring to the ability of the soul to perceive the cause of the sensible event in a context that belongs to another mode of perception outside the limits of the 
sensible. Those who are immersed in a totalized sensible world, and thus mis-define "hap," "ne meneden it nat by God, prince and bygynnere of wirkynge" (V, p.1.46-48). In this contrast Philosophie invests temporal events with an epistemological value:

"Certes," quod sche, "yif any wyght diffynisse hap in this manere, that is to seyn that 'hap is bytydynge ibrought forth by foolisshe moevynge and by no knyttynge of causes,' I conferme that hap nis ryght naught in no wise; and I deme al outrely that hap nis [but an idel] voys (as who seith, but an idel word), withouten any significacioun of thing summitted to that voys." (V, p.1.31-39)

A real "hap" is also an event of knowledge in which the "voyce" is not a mere sensible sign but an event of utterance. The "voice" has no reality or truth unless it is ontologically differentiated, and knit with its divine cause. An event that is not "knytt" is not an event at all. It "nis ryght naught in no wise." The contrast Philosophie sets up between an unreal, or merely apparent, event and one that is real and "knytt" together, is not unlike the contrast Ripley sets up between manual separation of material from the apothecary and the philosophical separation of the stone into its ontological constituents. Philosophie goes on to explain that it is "sothe, that "no thing hath his beynge of naught'." The sensible understanding of events begins already "in medias res," already immersed in time, and already in a state of bondage within a linguistic network of derivative and infinitely deferred meaning. Without a further perspective from which to reduce sensible perception to a recognizable entity and bind it together into a definable category, the sensible world, as well as language derived from it, become tyrannical and totalizing. The understanding that knits the eternal with the temporal binds the infinity of time into a category, and perceives this category—as infinite as it is—as a thread to be knit with another ontological entity outside and other than itself. The knitting is fundamentally based on categorization, boundaries. It knits together the entire chain of being, which is also the 'chain of love' or "Homer's golden chain" with which Zeus binds 
everything in the universe, preserves the entities within their individual bounds, even as it gathers them into a single whole. The knitting metaphor implies the mind's ability to categorize things. A category implies boundaries, and categorization would be impossible unless the soul exceeds the thing it categorizes, and thus rise to a perspective beyond it, and an awareness that exceeds it. This excess required for categorization applies even to things that are infinite, such as time, space, matter, sensibility and reason. It gives them limits without contradicting their logical infinity or their internal laws.

There are intriguing echoes that reverberate between the language of the Boece and that of the Compound, such as in the following passage from Boece. As in Ripley, Boece's "knytting" joins opposites, and is a "sacrement of marriage" motivated by love. This love is both individual, and cosmic. Even the sun and moon, which are to be married together in the Compound, appear in Boece in the textual vicinity of the sacrament of marriage, as they work in harmony together to produce day and night:

"that the contrarious qualites of elementz holden among hemself allyaunce perdurable; that Phebus, the sonne, with his goldene chariet bryngeth forth the rosene day; that the moone hath comaundement over the nyghtes, ... that the see, gredy to flowen, constreyneth with a certein eende his floodes, so that it is nat leveful to strecche his brode termes or bowndes uppon the erthes (that is to seyn, to coveren al the erthe) - al this accordaunce [and] ordenaunce of thynges is bounde with love, that governeth erthe and see, and hath also comandement to the hevene. And yif this love slakede the bridelis, alle thynges that now loven hem togidres wolden make batayle contynuely, and stryven to fordo the fassoun of this world, the which they now leden in accordable feith by fayre moevynges. This love halt togidres peples joyned with an holy boond, and knytteth sacrement of mariages of chaste loves; and love enditeth lawes to trewe felawes. O weleful were mankynde, yif thilke love that governeth hevene governede yowr corages." (II, m.8.2-35)

Without love there would be no marriage between opposites and all things "wolden make batayle contynuely." Like Ripley, Boece thinks of marriage as uniting not only human to human, but also human to divine, and he laments the lack of "alliaunce of thingis" and 
the "unjoin[ing] of their "byndynge" when the marriage does not also unite Man with God:

"What discordable cause hath torent and unjoyned the byndynge or the alliaunce of thingis (that is to seyn, the conjunccions of God and of man)? ...the thought of man, confownded and overthrowen by the derke membres of the body, ne mai nat be fyr of his derked lookynge (that is to seyn, by the vigour of his insyghte while the soule is in the body) knowen the thynne sutile knyttynges of thinges." (V, m.3.1-17)

As in Ripley, "fyr" is an epistemological element. It is pure act, and the light of divine knowledge within the soul. As in Ripley, the qualities of "thynne" and "sutile" are used for the highly refined, purified and spiritual mode of knowledge. Boece is saying that it is difficult, while the soul is confined to the gross and material mode of life, to "knowen the thynne sutile knyttynges of thinges" because the "fyr of his derked lookynge" is not sufficient. The result is that, without the soul's knowledge of the "knyttynges of thinges," these things would fall apart, just like the manually conjoined stone of Ripley's false philosophers, in the test by fire. Like the soul or the figure of Hermes in Ripley, so in Boece the soul is the mediator that "knytts" heaven and earth together, or spirit and body. 


\section{Chapter Three}

\section{The Pilgrim as Living Allegory: Ripley and Bonaventure}

whennes thryveth thanne or whennes comith thilke knowynge in our soule, that discernith and byholdith alle thinges? . . . . For somtyme it hevyth up the heved (that is to seyn, that it hevyth up the entencioun) to ryght heye thinges, and somtyme it descendith into ryght lowe thinges; and whan it [thilke knowynge in our soule] retorneth into hymself it reproveth and destroyeth the false thingis by the trewe thinges. (Boece, V, m.4, 27-41)

I have, forthi, swifte fetheris that surmounten the heighte of the hevene. Whanne the swift thoght hath clothid itself in tho fetheris, it despiseth the hateful erthes, and surmounteth the rowndenesse of the gret ayr; ... (that is to seyn, whan the thought is makid Godis knyght by the sekynge of trouthe to comen to the verray knowleche of God) ... he schal forleten the laste point of the hevene, ... and he schal be makid parfit of the worschipful lyght [or] dredefulle clerenesse of God. (IV, m. 1, 1-27)

As demonstrated in the previous chapter, Ripley based his Chaucerian satire of the false "Philosophers" on their narrow confinement to the sensible mode of perception and, consequently, the human condition of deferral. To be able to "separate" and "conjoin" his stone ontologically, and not merely "manually," he must, like Chaucer's Boece, "hev[e] up the heved" and "entencioun" above the limits of sense perception, and step by step heave it up higher until he "forlete[th] the laste point of the hevene," in other words, rise beyond the entire ontological structure of the universe, in order to "be makid parfit of the worschipful lyght [or] dredefulle clerenesse of God." This does not mean that either Chaucer or Ripley — or even Boethius - denied the world. On the contrary, while at first he "despiseth the hateful erthes" it is only in so far as it is a confinement to sensible perception to the exclusion of other modes, that he does so. His rise carries the world with him to deification. Through one's rise towards God one enacts the ontological 
structure of the universe and by enacting incorporates it into his own being. When one arrives at the last limit of heaven and "forleten" it to rise even further and above it, to the ineffable God, then one's being becomes fully "gathered together" into a complete microcosm, with nothing else left for it to be in relationship with, except God. The entire universe, in other words, down to its lowest physical mode, is part of the transformed pilgrim. As opposed to a relationship with partial goods, a relationship with the ultimate Good gathers one's being together and seals it into a complete whole. In the opening of the General Prologue to the Canterbury Tales Nature naturally seeks to exceed herself and she moves her creatures to reach out beyond her. ${ }^{147}$ Similarly for Ripley it is through nature that the alchemist discovers the way to the divine Creator. Even through the "prick[ings]" of concupiscence, Chaucer's Nature turns her creatures into pilgrims, and "pricketh hem nature" to "goon on pilgrimages" to "ferne halwes" (Gen. Prol, 11-14) to make their reditus back to God. She pricks them, in other words, to "hevyth up the heved (that is to seyn, that [to] hevyth up the entencioun) to ryght heye thinges." Similarly for Ripley, it is through the mystical keys hidden in the depths of Nature and her laws, that the alchemist discovers the way to God, to the attainment of wisdom, of deification and the state of indestructible personal entitihood that is the "Philosopher's Stone." Even though the weight of Ripley's thought and poetics fell heavily on the side of the ancient and pre-Christian roots of natural philosophy, he nevertheless sought, like Chaucer, to harmonize that natural philosophy - which had been growing in importance since the beginning of the translation movement in the eleventh-century-with his Christian faith. But Ripley went so far into adopting this natural philosophy that it evidently became the

${ }^{147}$ Gordon Braden, lecture on Chaucer's General Prologue for ENGL 3810 (University of Virginia, fall, 2008). Professor Braden described Chaucer's Nature at the opening of the General Prologue, reaching beyond herself, as she moved people to seek hallowed places and as such contact with divine nature beyond her own ken. 
focus of his investigations and writings. In this chapter I place George Ripley's Compound of Alchemy, and the alchemical and philosophical ideas underlying it, in the context of the medieval Christian contemplative journey towards God in order to explore the nature of Ripley's poetic work, and to further investigate the role of the heavily allegorical language of alchemy and its implications in his work.

Ripley's redemptive and perfective alchemical journey roughly followed the outline of the Christian contemplative journey which rose from sensible to rational and finally spiritual perception and union with God. A clarification of the deep seated similarities of the redemptive journey that Ripley's "Stone" underwent, with the Christian one, helps bring into clear view the differences as well and, as such, the serious changes that the ancient elements of alchemical natural philosophy brought into that journey. It is also important to compare the different ways the language of allegory operates in a representative medieval Christian journey such as Bonaventure's purifying and transformative journey towards God on the one hand, and the alchemical journey's teleological purification and transformation towards deification on the other hand. Such comparison can give invaluable insight particularly into the effect that the changed concept of the journey had on the author's attitude towards language.

In this chapter I discuss St. Bonaventure's Journey of the Mind into God, and bring it to bear on Ripley's presentation of the alchemical journey in his Compound of Alchemy. I give attention to the concept of allegory as a means of ascent towards God, and compare its different implications in the two texts. I argue that central to both Christian and Alchemical journeys is the pilgrim's "hevy[ng] up the heved," or "entencioun," above the natural world in both its sensible and rational modes of perception, although the alchemical journey may have compromised its ability to do so. 
The previous chapter has demonstrated the central importance for Ripley of transcendence and the passage through death it involves, for the possibility of the microcosm and Philosopher's Stone. In Bonaventure as in Ripley, the pilgrim cannot be transformed into a microcosm unless he is in a pure, unfragmented and personal relationship with the ultimate Good that unifies all desire- with God understood as clearly beyond, and infinitely greater than, the natural world, even as He gives Himself to it and lifts it back towards Himself. Also central to Bonaventure's journey as to Ripley's, is the passage through death implied in one's transcendence of one's natural limits. But in Bonaventure's journey the transcendence of the limits of natural reason and not only of sensible perception, is more clearly emphasized. Central to both, also, is the epistemological nature of the redeemed, transformed, and now microcosmic, pilgrim as a living and embodied allegory.

Regarding the differences, I argue that in contrast with Bonaventure's Journey, Ripley's Compound reveals a shift in the author's attitude towards language from that of the medieval Christian one. This shift involves a reification of language and the human mind altogether. While this shift had many advantages, it ran the risk of removing the limits of the mind as of the spatio-temporal universe, and of presuming continuity with-and even inclusion of - God's mind. In other words, it ran the risk of deeply compromising the pilgrim's - and poet's - ability to gather his being together into a whole by relating it to a Being greater than itself. Without "hevy[ng] up the heved" above one's entire natural being, and beyond one's mortality, one cannot form a microcosm, and will, instead, remain trapped in a dualitistic structure of reality and a condition of infinite deferral. 


\section{Bonaventure's Itinerarium Mentis in Deum}

A number of important factors render St. Bonaventure's Itinerarium Mentis In Deum particularly pertinent for the comparison between the Christian contemplative journey and Ripley's alchemical one. First, St. Bonaventure was clearly influenced by the natural philosophy on which alchemy was largely founded. George Boas states that the Itinerarium "stands at the beginning of Renaissance science as one of those documents in which the future can be seen in germ."148 Bonaventure (1221-1274) lived and wrote in the thirteenth-century, at the height of Western Europe's activity of adapting, transforming and absorbing the natural, Neo-Platonic as well as Aristotelian ${ }^{\mathbf{1 4 9}}$ philosophies that were renewed through the late medieval translation movement from Arabic and, later, Greek. The Franciscan order to which he belonged and which he led, emphasized the love and observation of nature. In the Itinerarium "observational science becomes not simply the satisfaction of idle curiosity, but the fulfillment of a religious obligation."150 Bonaventure also shared with Ripley the Neo-Platonic influence. He accepted the hierarchical structure of the universe, and the cycle of exitus and reditus from and back to God, but he changed Plotinus' 'emanation' to the Judeo-Christian 'creation'. 151 Among the features of particular interest he adapted from that natural philosophy is, as mentioned above, the idea of the perfected individual as a microcosm,

\footnotetext{
${ }^{148}$ George Boas, Journey of the Mind into God-St Bonaventure.

${ }^{149}$ Although Bonaventure often disagreed with Aristotle, particularly where he understood him through Averroes' interpretation, Patrick Aspell states that "By no means did Bonaventure neglect to adopt Aristotelian ideas such as act and potency, substance and accident, abstraction, the agent and possible intellect. Whatever he inherited, however, he adapted to the mind of Augustine, the master who combined Aristotelian science of things in themselves and Platonic wisdom of transcendent realities to understand the Christian faith," and "viewed against the background of Greek and Christian thought, Bonaventure's philosophy appears as an attempt to assimilate Aristotelian ideas into an Augustinian framework," in Patrick J. Aspell, Medieval Western Philosophy: The European Emergence, Cultural Heritage and Contemporary Change, Series I, Culture and Values vol. 9 (The council for Research in Values and Philosophy, 1999), 138, 108

${ }^{150}$ George Boas, Journey of the Mind into God-St. Bonaventure.

151 Ibid.
} 
especially since the attainment of microcosmic entitihood and perfection is essentially what defines Ripley's "Philosopher's Stone." The alchemical idea of the "seeds" God left in the prima materia appears in Bonaventure's writings in the form of the "vestigia"152 of God in his creation. Bonaventure also adapts St. Augustine's concept of the "rationes seminales" which renders the "prima materia" a seed-bed for creation through God's Word. ${ }^{153}$

Second, Bonaventure "assimilate[d] Aristotelian ideas into an Augustinian framework." ${ }^{\prime 154} \mathrm{He}$ assimilated into Augustine's Neo-Platonism not only Aristotle's emphasis on the reality of the particular and embodied, but also his emphasis on substantial reality as an act-an esse: a coming into being and into knowledge or wisdom - and not merely a sort of basking within a ready-made ideational reality. With the help of both Augustine and Aristotle he also filtered and modified the renewed NeoPlatonism in its pagan form. His Itinerarium represents the second half of the NeoPlatonic cycle, the reditus, back to God: "Whilst the "Breviloquium" derives all things from God, the 'Itinerarium Mentis in Deum' proceeds in the opposite direction, bringing all things back to their Supreme End." ${ }^{, 55}$ Very importantly, he rejected the ancient blending of consciousness with God. Bonaventure rejoiced in the particular and in the

\footnotetext{
${ }^{152}$ Ralph McInerny describes "The vestige" as "that whose property refers it to God under the aspect of a threefold cause: efficient, formal, and final, like one, true, and good." See Ralph McInerny, "Saint Bonaventure" in Ralph McInerny, A History of Western Philosophy, Vol. 2: From Augustine to Ockham (The University of Notre Dame Press, 1963), 282.

${ }^{153}$ Christopher M. Cullen, Bonaventure (Oxford: Oxford University Press, 2006), 47-48. Cullen desribes Augustine's rationes seminales as "active potencies existing in matter. Matter is never inert and purely passive, but is always both passive and active. It is profoundly dynamic, because it is a seedbed (seminarium) in which corporeal forms exist in a virtual and germinal state. Bonaventure holds that the form, which exists in potency in the matter, is reduced to act by receiving a new mode of existence. 'The secondary agent "creates....."

${ }^{154}$ Ibid., see note 3.

${ }^{155}$ Paschal Robinson, "Bonaventure ic EncyclopediaThe Cathol ",(1917), in Aristotle et al.: Readings for Philosophers and Catholics, eds. Charles G. Herbermann et al. (Notre Dame: University of Notre Dame, Jaques Maritain Center, 2010), Web, http://maritain.nd.edu/jmc/etext/bonavent.htm, last modified 3 Dec. 2011, last accessed 11 Jan. 2013, p.285.
} 
boundaries with which God bound all creation into order, and recognized firm limits distinguishing the cosmos from God. The result is a theological and artistic Journey that holds for the explorer significant clues to the relationship between allegory and the ascent towards God. His Journey can serve to explain how it is that intelligent thinkers of the past could possibly believe that an intellectual rise from particular things through species and genera can have anything to do with an ascent towards God who is absolute Being. In this regard the way the language of allegory operates in Bonaventure's transformative journey can offer an especially relevant and revealing context for comparison with the of the allegorical journey of Ripley's Stone.

Third, although Bonaventure was influenced by alchemical natural philosophy, he can properly be considered an orthodox representative of Christian thought. While some religious and 'scientific' authors who were influenced by the incoming natural philosophy —in which alchemy held the most central place - tended to have many unassimilated pagan elements, or were even at risk of being accused of heresy, Bonaventure filtered the concepts involved and adapted them without compromising the tenets of Christian doctrine or its underlying concepts. Like his contemporary Thomas Aquinas, he is one of the few honored with the title of "Doctor of the Church.", ${ }^{, 156}$ Even though the 'orthodox' philosophies of Christian thinkers were by no means homogeneous, his work can safely be considered representative of medieval Christian thought due to its popularity and influence as well as to its approval by the Church. ${ }^{157}$

\footnotetext{
${ }^{156}$ Sixtus IV declared Bonaventure a Doctor of the Church on March $14^{\text {th }}, 1557$. Ibid.

${ }^{157}$ Ibid. Bonaventure's biographical account as given by he Catholic EncyclopediaT shows him to have been very highly regarded during his lifetime and, had he lived, he may well have become pope. Bonaventure studied under Alexander of Hales, taught at the university of Paris, was elected Minister General of the Friars Minor in the Frasiscan order 1257 and was able to establish much needed peace and order there, was nominated to the Archbishopric of York, England, by Clement IV in 1265, but "steadfastly refused it," received the degree of Doctor together with St. Thomas Aquinas on 23 October, 1267, was made Cardinal-Bishop of Albano, against his will, by Gregory X in 1273. Pope Gregory X charged him "to
} 
Fourth, during George Ripley and Thomas Norton's lifetime Bonaventure was among the most widely read of Christian religious authors, if not in fact the most, with "no less than fifty editions of [his] works" published during the fifteenth-century. ${ }^{\mathbf{1 5 8}}$ Scholars have even spoken of a "Bonaventure renaissance of the fifteenth-century." would be unlikely for Ripley not to have read Bonaventure especially due to the latter's popularity and his incorporation of elements of natural philosophy in his own thought. It is interesting that Ripley was appointed the Pope's Chamberlain-for which Fergusson gives the date $1977^{\mathbf{1 6 0}}$ — under the same Pope who canonized Bonaventure in 1482, Sixtus IV, pope from 1484 to 1492.

prepare the questions to be discussed" at the 1274, Fourteenth Ecumenical Council in Lyons, and confided to him "the direction of its deliberations." Bonaventure's efforts were instrumental in the Orthodox Church's acceptance of the union of 6 July, 1274, during that council. Bonaventure died less than two weeks later, on July $15^{\text {th }}, 1274$, while the council was still ongoing. "BonaventureThe Catholic ", Encyclopedia(1917).

${ }^{158}$ Ibid., "Those familiar with the catalogues of European libraries are aware that no writer since the Middle Ages had been more widely read or copied than Bonaventure. The earliest catalogues of his works are those given by Salimbene (1282), Henry of Ghent (d. 1293), Ubertino of Casale (1305), Ptolemy of Lucca (1327) and the "Chronicle of the XXIV Generals" (1368). The fifteenth-century saw no less than fifty editions of Bonaventure's works."

${ }^{159}$ Marianne Schlosser quoting Kurt Ruh in Marianne Schlosser, "Bonaventure: Life and Works," A Companion to Bonaventure, eds. Jay M. Hammond, Wayne Hellmann, Jared Goff (Leiden: Brill, 2013), 961, 56. Cf. Kurt Ruh, Bonaventura Deutsch: Ein Beitrag zur deutschen Franziskaner-Mystik und Scholastik (Bern: Franke Verlag, 1956).

${ }^{160}$ Linden, George Ripley's Compound of Alchemy, x. Stanton Linden cites John Ferguson's 1908 Biblioteca Chemica, for the information that Ripley "was made chamberlain by Pope Innocent VIII in Rome" in 1477. But it should be clarified that Innocent VIII's term in the papacy did not begin until 1484. Ripley therefore was made chamberlain of the Holy See under the papacy of Innocent's predecessor, Pope Sixtus IV (Pope from 1414 to 1484, and one of the most notorious characters who occupied the seat of Pope), the same pope who canonized St. Bonaventure in 1482. Innocent VIII would nevetheless have been the one to appoint Ripley prior to his papacy. Charles Mackay (1814-1889), op. cit, states that Pope Innocent VIII, and made Ripley, who was a "great favorite" of his, "one of his domestic chaplains, and master of the ceremonies in his household, Returning to England in 1477," in Charles Mackay, Memoirs of Extraordinary Popular Delusions. While this was sometimes given as an honorary position, a chamberlain was usually charged with administering the property and revenues of the Holy See. During the fifteenthcentury the position of chamberlaine of the Church and the Holy See came to be reserved for Cardinals only. Ripleys' appointment to it would not have been strange, however, since at that time the change may not have been completed. The favor Ripley found at the Vatican implies the Pope's interest in alchemy, and the possibility that he was interested in Ripley's alleged alchemical adroitness. Pope Sixtus IV also seems to have been interested in the translation work that Marsilio Ficino was doing for Cosimo Medici. Lee Egmont states that there are indications that he tried to attract Ficino to Rome. There was certainly correspondence between him and Ficino. Egmont Lee, Sixtus IV and Men of Letters (Rome: Ed. di Storia e Letteratura, 1978), 170.

One would conjecture whether Ripley's connection with the Pope was related to the $£ 10,000$ yearly help he seems to have been giving the Knights of St. John of Jerusalem in Rhodes. With Ripley's 
Like Ripley, Bonaventure sought God in nature. His journey to the mystical experience of God begins with the sensible world. Sensible things carry the traces (vestigia) of God through illumination. "God is contemplated ... in them, in so far as $\mathrm{He}$ is in them by essence, potency, and presence" (2.1).

$\mathrm{He}$, therefore, who is not illumined by such great splendor of created things is blind.... Open your eyes therefore, prick up your spiritual ears, open your lips, and apply your heart, that you may see your God in all creatures, may hear Him, praise Him, love and adore Him, magnify and honor Him, lest the whole world rise against you. (1.15)

Although St. Bonaventure gives an essential role to species, genera and higher categories in the "journey of the mind into God," knowledge of God, for him, is not disembodied rational knowledge, but a mystical experience of His perfections (or "names"), and the climb through species and genera is also a climb through being itself, and up the ladder of being, which is God Himself. Michelle Karnes argues that for Bonaventure as divine Exemplar "Christ is Species,"161 and that Bonaventure identifies him with the entire ladder: the sensible "species" abstracted from the material object, the rational species abstracted from the sensible ones, and is also himself the means of rising to the spiritual

claims to knowing the secrets of alchemy, the idea that the donation came from alchemical gold could have been believable and attractive at the time. Linden gives the uncertain dates "1460?-70?" For his visits and residence in Rhodes. For the historical information on the office of chamberlaine (camerlengo), see Salvador Miranda, ed., "Catalogues: Cardinals head of dicastries of the Roman Curiaa: Offices, Reverend Apostolic Chamber," The Cardinals of the Holy Roman Church: A digital resource created and produced by Salvador Miranda, consisting of the biographical entries of the cardinals from 492 to 2013 and of the events and documents concerning the origin of the Roman cardinalate and its historical evolution (Florida International University Libraries, 1998-2013), Web, http://www2.fiu.edu/ mirandas/curia.htm\#Chamber, last updated: 5 Nov, 2013, accessed 10 Nov., 2013. Miranda cites his main source for the historical notes as the Pontifical Yearbook. Supplement. Historical notes (Città del Vaticano: Tipografia Poliglotta Vaticana, [n.d.]).

While Rhodes was subject to Turkish raids in the 1450's, in the 1470's and 80's the conflict intensified into a full-fledged war. See Helen J. Nicholson, The Knights Hospitaller (Woodbridge: Boydell \& Brewer, 2001), 61-2. A detailed historical account of the Knights of Rhodes is found in volumes 1-3 of Abbe de Vertot, The History of the Knights Hospitallers of St. John of Jerusalem; Styled Afterwards, the Knights of Rhodes, and at Present, the Knights of Malta. Translated from the French of Mons. L'Abbe de Vertot (Edinburgh: Printed by R. Fleming, for A. Kincaid and A. Donaldson, Yair and Fleming; and W.Gray, Booksellers, 1770). See vol. III, pp. 2-14 for the 1450's and 28-54 for the 1470's.

${ }^{161}$ Michelle Karnes, Imagination, Meditation, and Cognition in the Middle Ages (Chicago: University of Chicago Press, 2011), 97. 
mode of knowledge, "Himself bridging the earthly and eternal through his incarnation, Christ brings his dual natures to bear on every act of understanding. Cognition itself is a journey to and through Christ." ${ }^{, 162}$

Bonaventure writes that he who is not "blind" and who is "illumined by such great spleandor of created things," recognizes that what he hears and sees through the sensible sounds and images is God Himself-His beauty shining through the beauty and perfection of created things (2.2). But how is it that sense perceptions, comprehended by the mind as species, are also perceptions of God Himself? Logically, it appears that they are no more than abstract, disembodied concepts. The external "sensibles" enter the mind through their "similitudes" (2.4). The similitudes, which are "generated" through their "mediums" (such as sound and light) are then generated in the outer organs and passed on "into the internal [organ], and from there into the apprehensive power." (Ch2. 2) The apprehensive power of the mind, then, "reacts" to the sensible stimuli by forming the concept of their species (2.4). We may thus correctly conclude that by receiving the species and forming their concepts, the soul transforms the sensible images into conceptual and linguistic images, capable of being known and preserved in the mind without their corporeal matter.

Yet, Bonaventure conceives of these categories as acts of perception, rather than in our modern sense as disembodied bubbles of conceptual information, merely notional, static and deprived of being. Like alchemical Ripley, he regards the operation of knowledge as transformative action and not as the mere formation of abstract and conceptual bubbles. "Species" for Bonaventure is substantial knowledge. It is an act of knowledge. "Bonaventure “defines 'species' as 'substantial form' (formam

\footnotetext{
${ }^{162}$ Ibid., 95.
} 
substantialem)." He thus, "profoundly changes the meaning of the term," one which she states was "popularized during the thirteenth-century." ${ }^{\text {163 }}$ Christ is "the treasury of forms that the intellect apprehends, and the means through which knowledge rises to wisdom."

The soul "delights" in the "abstract[ed] similitude" (2.4) "Species," is an act in which the contemplative's act of perception participates in God's act of creation, as these species also give themselves to him. "Species," possesses "form, power and operation" (2.5):

"Form is full of power because of its activity; power is full of effects because of its efficiency--declares the same manifestly. 'Operation,' multiplex inasmuch as it is natural, artificial, and moral, by its very variety shows the immensity of that power, art, and goodness which indeed are in all things the cause of their being" (1.14).

"Form," which is species, is action and has effects. Its "operation" reveals the Trinitarian likeness of God in all creation: "power" is the power of action. Yet, while the phrase "power of action" distinguishes between the power and any particular act, in God, there is no distinction, since His action is simultaneously fulfilled in His eternal present. Power, therefore, is the fullness of Action in its totality-which, is Creation in its totalitybefore it unfolds temporally to our minds, and in the mode our minds can perceive it. "Power" refers to the Father as Creator and beginning. "Art" refers to Christ who is the divine Exemplar for the unfolding of creation in time. It suggests also that Art is of the essence of man and of his activity. As God's "Art," Christ unites the ineffable truth of God with God's image, and makes His image visible to man: Although Christ is ineffable, like the Father, he is at the same time the Father's self-knowledge, and as such

\footnotetext{
${ }^{163}$ Karnes, Imagination, Meditation, and Cognition in the Middle Ages, 97.

${ }^{164}$ Ibid., 69
} 
image, and he gives himself to the human being's mind "even as cognitive image."165 "Goodness" is the Holy Spirit ${ }^{166}$ and ultimate end which men seek. The species of things are active agents in the journey leading to God. They too are image and art. They are no less than a miraculous phenomenon, even while they are, at the same time, natural. They are miraculous in the sense that they derive their truth from beyond both the object out of which it has been abstracted, as well as from beyond the perceiver's own mind which performs the abstraction: a species derives its truth from "the principle from which it comes" (2.5), which, as Michel Karnes argues, is God giving Himself through His Word. Species also "acts" towards an "end," leading towards "its principle and source"(2.7), which similarly is God. It is Christ, as divine Exemplar of all species, Who illumines things and gives them their species. All species then will ultimately lead to their exemplar, Christ Himself. They therefore, "operat[e]" towards an "end," leading the person to God.

It logically follows that the two actions - the intellect's act of apprehension and the species' own "operation" towards an "end," - are parts of one and a larger and single action. While receiving the Grace of apprehending the species, therefore, and going through the rest of the operation of knowledge, the intellect participates in the action of Grace which both creates the creatures and guides them back to God. In the operation of knowledge, therefore, Man participates in God's action. As Bonaventure ascends through the categories of being, God is also pulling him towards Himself through the teleological nature of the operation of knowledge. In this single action of simultaneous pulling and

\footnotetext{
${ }^{165}$ Karnes, Imagination, Meditation, and Cognition in the Middle Ages, 18.

${ }^{166}$ Patrick J. Aspell, Medieval Western Philosophy: The European Emergence, Cultural Heritage and Contemporary Change. In his exposition of Bonaventure's thought Aspell describes the Father as the beginning and the Spirit as the end, with the Son as the "mean" between the two: "The personal center of Bonaventure's synthesis is the divine he Son or Word who, as the mean between the Father as principle and the Spirit as end, is the measure of God himself, and consequently the measure of things and of knowledge" (140).
} 
seeking, the giving from God miraculously meets the seeking from Man, and even makes it possible.

While from an external point of view we may either consider species and genera as referring to physical and biological referents, or as purely abstract concepts devoid of all substance or being, they are, for the ascending contemplative, no less than experiences and acts of perception, which are not only his acts alone, but are also given to him as acts of being (esse rather than ens) produced by God Himself. In abstract language alone species seem to be no more than conceptual tools for ratiocination, but when they are the mind's responses to the experience of perception, then, to Bonaventure the categories are the beauty that he perceives, the likeness of God in his creatures, and this beauty is God's as well as that of His act of creation which is one and the same with Him.

The pilgrim's perceptions are also the beings he perceives. When they enter into his mind through the senses followed by the steps of the intellectual process, it is the created universe that is entering into him and transforming him into a microcosm. Through the senses, Bonaventura explains, the whole of God's creation, in which He is present - the entire "macrocosm" — enters into the soul through the five senses as through doors:

"this world, which is called the 'macrocosm,' enters our souls, which are called the 'microcosm,' through the doors of the five senses, according to the apprehension, delectation, and judgment of sensible things themselves." (II.2)

For the pilgrim to be transformed into a microcosm is no simple matter. Before he begins, he is only a microcosm in potentiality. At first his perceptions take up only a part of his intellect and being. But as he ascends to a greater recognition of God's perfections, or "names," these perfections progressively involve more of his being until it is gathered 
together into a whole and entirely embraced by God's Being, Beauty, Goodness, Love and Peace.

At this point the categorical ascent will have reached its limit and the limit of all possible categorization, so that the entire spatio-temporal world (infinite as it may be) is "gadred togydre" into a single category and the contemplative pilgrim experiences its paradoxical limits as he stands in the attitude of a relationship of love or desire towards God who is beyond all conceptualization and categorization. Thus the "peace"-which is the specific perfection he seeks in his journey, in deference to St. Francis, his inspiration and the founder of his Franciscan order-“surpasses all understanding." In the prayer with which Bonaventure opens the prologue to his Itinerarium, he asks God, with the intercession of Virgin Mary and St. Francis, that:

He may enlighten the eyes of our mind to guide our feet into the way of that peace "which surpasses all understanding" [Eph., 1, 17; Luke, 1, 79; Phil., 4, 7], which peace our Lord Jesus Christ has announced and given to us; which lesson our father Francis always taught,... (Prol.1)

At the end of the journey peace, which is God Himself, since God is identical with His perfections, fills the entire being of the pilgrim. No part of him is left out. It is at this point, when his mind has included all categories under the one single category of spatiotemporal existence that includes all the other parts of existence, that the pilgrim becomes unified, and a realized microcosm, passing into the divine being who is beyond all conceptualization and categorization. At this point Bonaventure quotes (Pseudo)Dionysius the Areopagite by whom he has been strongly influenced:

"Thou then, my friend, if thou desirest mystic visions, with strengthened feet abandon thy senses and intellectual operations, and both sensible and invisible things, and both all nonbeing and being; and unknowingly restore thyself to unity as far as possible, unity of Him Who is above all essence and knowledge. And when thou hast transcended thyself and all things in immeasurable and absolute purity of mind, thou shalt ascend to the 
superessential rays of divine shadows, leaving all behind and freed from ties of all."167

It is crucially important to note the paradoxical, logically impossible, and as such miraculous nature of this juncture that the contemplative pilgrim reaches at the top of his ascent, when his entire being is unified and ready to pass into that "which surpasses all understanding," and be embraced by God. The paradoxical passage, at this juncture, to that "which surpasses all understanding," can only be realized when one has unified oneself and become a microcosm which encapsulates the entire infinity of the universe within itself. Yet at the same time, one cannot realize that unity unless one has also been crossing the impossible passage from sense impressions to species made possible by God's grace.

The passage from matter to sense to species, and through the hierarchy of species to the limit of the natural world, and finally beyond, involves a linking of ontological parts, or their epistemological categories, without destroying their integrity, just as in Boece and the Compound's use of the metaphor of knitting, the entities that are "knit" together remain distinct even while being united. Such a feat cannot be done merely naturally. The independent enclosure of each category within inviolable limits is crucial to the very possibility of the categorical ascent and experience of being that Bonaventure is describing. Not only are the macro- and microcosms laced into form and bounds by an impassable infinity, but so is each category or epistemological part of the rise from material to divine being. There is a gap — seemingly of nothing or non-being—between each category and the next, and the leap from one to the next can only occur spiritually, from within the center of each category, through the pilgrim's intentionality and its divine

167 George Boas, Journey of the Mind into God-St Bonaventure, VII. 5, quoting Dionysius' "Mystic Theology," found in Migne, Patrologia Graec, vol. III, Ch. I, 997. For an English translation, see Colm Luibhéid, trans., and Paul Rorem, ed. and trans., Pseudo-Dionysius: The Complete Works, eds. (Mahwah, New Jersey: Paulist Press, 1987), Ch. I.1. 998A-1000A, 135. 
referent, the incarnate Christ. Christ is himself both the goal and the ladder to it. At the last juncture, when all the parts have become united, and the microcosm has been rounded into completion, Bonaventure explains, you must die and "rise above yourself" in order to come into the presence of God and fully experience His Peace.

God and His perfections are at an infinite distance from the pilgrim. The pilgrim encounters that logically impossible passage across infinity into God's embrace once she reaches the height of categorical unity - the most ultimately inclusive category the mind can reach — so that the whole spatio-temporal world is united within her as a single ontological category, and nothing remains beyond herself but God. In itself, infinity is absolute. To enter it is to fall into the bottomless abyss, to be infinitely fragmented and dissolved, and to die an infinite death. To cross it is also death, but it is a finite event of death that leads to the other side. That passage, however, is according to Bonaventure possible through Christ, who is the bridge since he has perfectly fused his divinity with humanity and with the entire creation, which is ontologically contained in humanity as its highest and most inclusive form. The pilgrim who is turned in an attitude of love for that which is beyond her, can cross this uncrossable distance by latching onto Christ. In doing so she will, like Ripley's Stone, incorporate death and infinity into her experience and into the structure of her being. Her being acquires ontological boundaries, and as such "form," and individual identity and becomes the embodiment of that unique historical moment of the "leap" to God which "gadred togydre" (Boece III, p.11, 16-30) the whole of Time and Space into the pilgrim's being while she stands in an attitude of seeking beyond her own mortality. To come "into" the presence of that "peace" of God, and therefore become whole in oneself, one must first pass through the impassable. St. Bonaventura re-iterates several times in his Itinerarium that the reader must "rise above 
yourself," as Philosophie reminds Boece to "hev[e] up the heved" and "entencioun" to ryght "heye thinges" (Boece V, m. 4.35-37). It is only "he who chooses this death [who] can see God because this is indubitably true: 'Man shall not see me and live' [Exod., 33, 20]. Let us then die and pass over into darkness...” (VII. 6).

The third and final stage of contemplation, including both its rungs, involves the mystical passage in union with Christ and through his cross. This implies that the ascentwhich is also the operation of knowledge and wisdom, is essentially sacrificial. With Christ one dies on the cross and passes through the burning fire of God "that leadeth to Jerusalem." The image of God as burning fire echoes Heraclitus who reached Bonaventure through the influence of Psuedo-Dionysius the Areopagite. (It is an image to which we will return later in this chapter, when discussing the role of oppositions in Ripley's work.):

6. If you should ask how these things come about, question grace, not instruction; desire, not intellect; the cry of prayer, not pursuit of study; the spouse, not the teacher; God, not man; darkness, not clarity; not light, but the wholly flaming fire which will bear you aloft to God with fullest unction and burning affection. This fire is God, and the furnace of this fire leadeth to Jerusalem; and Christ the man kindles it in the fervor of His burning Passion, which he alone truly perceives who says, "My soul rather chooseth hanging and my bones death" [Job, 7, 15]. He who chooses this death can see God because this is indubitably true: "Man shall not see me and live" [Exod., 33, 20]. Let us then die and pass over into darkness; let us impose silence on cares, concupiscence, and phantasms; let us pass over with the crucified Christ from this world to the Father [John, 13, 1], so that when the Father is shown to us we may say with Philip, "It is enough for us" [John, 14, 8]; (7.6)

The Neo-platonic influence on Bonaventure is clear in his understanding of Christ as the Logos. Yet, he does not fall into the trap either of banishing God from "being" like Plotinus (when he quotes Dionysius' requirement that the pilgrim abandon both nonbeing and being, he means to ask him to rise beyond all categorization), or allowing him to be the kind of elusive first cause that merely recedes ad infinitum from the world, 
without any paradoxical and radical breaks between Him and the world. Christ makes the entire journey possible, since he is the Wisdom with which God binds everything into form and finitude, and therefore into differentiation, individuality and perceptibility as species and genera. "Jesus, is the virtue and wisdom of God, the Word incarnate, the author of grace and truth" (1.7). He is at "the 'origin' of things" when God produced "all things from nothing," as the "wisdom" through whom things become distinguished and knowable:

the "origin" of things, according to their creation, distinction, and beauty, in the work of the six days indicates the divine power producing all things from nothing, wisdom distinguishing all things clearly, and goodness adorning all things generously." (1.14)

Christ is the one through whom the limits become real. The species and genera which are produced in the mind as it makes sense of the sense-impressions it receives, are possible only because these limits are real, and each species is actualized into a microcosm to the degree that it has incorporated into its experience its own death, which is its own enlacement (in a Levinasian sort of way) by that infinity which in the final analysis is itself that paradoxical golden chain with which Homer's Zeus (Theseus' Jupiter in the Knight's Tale, 2129-2182), at the beginning of the eighth book of the Iliad, binds the universe with such power as even all the pagan gods together cannot overpower and break it, since they cannot break infinity. Homer's chain was "Platonized to represent cosmic love unifying all of nature into a harmonious whole." ${ }^{\text {168 }}$ It is this chain that Theseus describes in Chaucer's Knight's Tale. When things are bound into form, then time, narrative and transformation become real.

\footnotetext{
${ }^{168}$ Jane Chance, review, Paul Beekman Taylor, Chaucer's Chain of Love ( Madison and Teaneck, N.J.: Fairleigh Dickinson University Press; London: Associated University Presses, 1996), International Journal of the Classical Tradition (Summer 1999).
} 
In the above quotation, (1.14), Bonaventure is making another crucially important point in in addition to the idea that God distinguished all things and bound them into form through Christ—who is "Word" and "Wisdom,"- and made them understandable. Bonaventure is asserting the fundamentally good and free-willed foundations on which God based the distinguishing of things into individual form. Not only did God create "all things from nothing" as an act of free will, instead of from a previously existing prima materia, but his distinguishing of them was also accomplished through his own goodness. It is his "wisdom [that] distinguish[ed] all things clearly, and [his] goodness that adorn[ed] all things generously" (1.14). As shown in Chapter Two above, the Ripley Scroll which interprets the Compound, presents creation as occurring through the agency of a figure who is the union of the divine Spiritus with the green dragon who, in alchemical symbolism, is identified with the prima materia. The 'Melusine' figure (half woman half dragon or serpent) which hangs from its tail which is curled around the tree of knowledge, associates the dragon with Satan. In the "Ripley Scroll," the duality of formlessness and form, prima materia and God, evil and good, is deeper and prior to the production of the visible world, and is even the source of its "differentiation" into individual forms. The contrast is stark and radical between the "Ripley Scroll's" interpretation of the dualistic generation of the world in the Compound, and Bonaventure's presentation of creation as emerging into distinction purely from divine Love, free will and Wisdom. Bonaventure's last phrase from the quote above (1.14) has echoes from the wisdom books of the Old Testament, particularly from the books of Wisdom and Ecclesiasticus (or "Sirach"), which assert the presence of Wisdom with God when he created the world. As we shall see, Thomas Norton shows an awareness of, and concern over, this difference between the Judeo-Christian and alchemical accounts of 
creation especially where he alludes to passages from these two books in lines $2720-26$ of the sixth chapter of his Ordinal.

If "Christ is the way and the door, Christ is the stairway and the vehicle" (8.1), then He too possesses the same form as the threefold journey. He is the principle and source of that form which unites "the symbolic, the literal, and the mystical" (1.7). This renders Christ the 'Supreme Allegory', and the essential form of the being of all those who seek him and climb his ladder:

"Jesus, is the virtue and wisdom of God, the Word incarnate, the author of grace and truth ... rectifies the whole soul in the threefold way [i.e. the entire journey] mentioned above. He has taught the knowledge of the truth according to the triple mode of theology — that is, the symbolic, the literal, and the mystical - so that by the symbolic we may make proper use of sensible things, by the literal we may properly use the intelligible, and by the mystical we may be carried aloft to supermental levels. (1.7)

The "threefold way" through which Jesus "rectifies the whole soul" can be understood as an ascent to God through allegory. "The triple mode of theology--that is, the symbolic, the literal, and the mystical" through which Christ teaches man is the action of the journey itself. Bonaventure divides his journey of the mind into God into three stages, each containing two steps, or rungs of the ladder (to which he refers as Jacob's ladder (1.9) which happens to be a frequent metaphor of alchemists). The first stage generally involves the reception, into the mind, of the sensible stimuli. This is what Bonaventure refers to as the symbolic "mode" in the lines quoted above, from the first chapter in which he summarizes his stages and begins the first step of the first stage. The second stage is the intellectual one in which the mind understands the sense impressions in terms of the species of which each compounded "object" or "image" is composed, such as its color, shape and proportions. It is remarkable that it is the species-the category-that he considers to be literal, and not the image. A modern and realistic approach would have 
considered the sensible image to be a literal referent to the object in the world "out there." It is therefore important to recognize the non-spatial nature of Bonaventure's journey, which we compare below to the spatial nature of the alchemical journey. In contrast with the spatio-temporal world "out there," a category is perceptible, and is an entity, only because its perception implies a recognition of the spatio-temporal world as ontologically bounded category, and consequently also because this entity-the spatiotemporal world - is set into relationship with that which is beyond it: divine beauty, goodness, love, peace, etc. Therefore, while it is easy to notice that the relationship between the category and the Divine Being beyond categorization is paradoxical, it is also true that the relationship between the sensible symbol and its literal meaning-the category — is similarly paradoxical, since it too implies a recognition of limits and a form of passage from one category and bounded mode of perception to another, and as such a form of death. The events of the Bonaventurian pilgrim's passage through the stages of his ontological self-constitution, from symbol to species, and from species to mystical knowledge, both involve a liminal experience - a contact with death and a renewal, although the last is the major one. This is reminiscent of the passage of Ripley's stone through death before the "white phase," and through death again from that into the "red phase."

One way to understand the impossibility, and as such miraculousness of the passage from the sensible symbol and its literal meaning, is to think of each category, as described above, laced into bounds by Homer's golden chain of love, and as such by no less than infinity. Another way is by recognizing the logical impossibility of this passage due to the fact that it is impossible for one to perceive the sensible image, and know that one has perceived it, without apprehending its species as well. The "delight" that 
Bonaventure points out the soul takes in recognizing species implies that the perception of beauty involves the combination of both modes, the sensible or symbolic, and the intellectual or literal, together. The experience of the symbol's rise to its intellectual meaning, the species, is an experience of Divine Wisdom, of the Word and Logos, as it gives itself to the contemplative pilgrim's mind by Grace. When Bonaventure describes Christ as Himself the ladder, or "stairway" (8.1), upon which the mind climbs up to Divine Being beyond itself, he includes all the phases and steps of the journey in that ladder. When the mind has reached the sixth step (the second of the third stage):

there remains that by looking upon these things it [the mind] rise on high and pass beyond not only this sensible world but itself also. In this passage Christ is the way and the door, Christ is the stairway and the vehicle, like the propitiatory [mercy seat] over the ark of God and the mystery which has been hidden from eternity [Eph, 3, 9]. (VII, 1)

Nevertheless, it is in the last phase, where the allegory is anagogical and the individual is become fully united and fully realized as a microcosm (which translates in alchemy into the "philosopher's stone"), that Bonaventure describes the pilgrim as "another Jacob... changed into Israel" [VI. 3]. He also describes the passage in sacrificial terms as a Passover made by Christ:

2. He who with full face looks to this propitiatory by looking upon Him suspended on the cross in faith, hope, and charity, in devotion, wonder, exultation, appreciation, praise, and jubilation, makes a passover--that is, the phase or passage [Exod., 12,11] with Him--that he may pass over the Red Sea by the staff of the cross from Egypt into the Desert, where he may taste the hidden manna and with Christ may rest in the tomb as if outwardly dead, yet knowing, as far as possible in our earthly condition, what was said on the cross to the thief cleaving to Christ: "Today thou shalt be with me in Paradise." (VII. 2)

Although that forbidding passage through death and the impossible crossing of the sea of infinity which separates Egypt from Jerusalem is a rise through allegory, and as such involves language in a fundamental way, allegory for Bonaventure is not a matter of 
words, spoken or written, in the modern sense of language as a repository of information. In fact, if allegory is to be realized and enacted by the pilgrim, he must forego "words" in their modern sense:

5. Since, therefore, nature is powerless in this matter and industry but slightly able, little should be given to inquiry but much to unction, little to the tongue but much to inner joy, little to the word and to writings and all to the gift of God, that is, to the Holy Spirit, little or nothing to creation and all to the creative essence, Father, Son, and Holy Spirit.... (VII. 5)

By the "creation" to which he instructs "little to be given," Bonaventure means the action of human "industry," and by implication that of human authorship and use of language. Two points must be made in this regard: the idea that allegory is not a matter of "the tongue," and that Bonaventure is not denying the value of human creativity, but emphasizing the idea that man's creativity and his language are only meaningful in so far as they are able to cross the sea of death and infinity, by which they not only recognize but also enact their limits, and thus participate in the creative action and language of the Trinity, which is "unction," "joy" and "gift." In this latter sense man's creative industry would be part of God's.

\section{The Compound's Reified Journey}

Two major differences are the first to come clearly to the fore when Ripley's alchemical journey is perceived in comparison with Bonaventure's. The first is the split of the journeyer into two: the "alchemist," who is the hermeneutic reader, and the stone "out there" that he seeks to transmute. As alchemist, he works on the matter of his stone within the sealed flask in the laboratory. As reader, he works on the matter of Ripley's text. The second is the reification of the journey, and of language which is the tool for the journey. It is easy to perceive the stone in the laboratory as "out there." But the text also is similarly "out there," regardless of whether he 'sees' it or 'hears' it: as the alchemist 
must do with the stone, so the reader must "separate" and re-"conjoin" the text. The words for him are not immediate perceptions and distinctions arising in his mind. They are objects to be examined, dissected and put back together again in a new way. When Ripley tells his reader "After philosophie I you behight / Doo, but not after the common guise, / With Sulphures or Salts preparate in divers wise" (I, 1.5-7), the reader must think of the ambiguities in the words. When Ripley tells him not to prepare the matter of his stone "after the common guise," the reader may think that Ripley is now going to lead him to the uncommon and correct way in which to prepare the stone in the laboratory, and will, in this case, listen or read further in anticipation of uncovering what other chemical substances he should use instead of "Sulphures and Salts." Similarly, "After philosophie" on the surface means "after the learned ways of alchemy," since the alchemist is usually called a "philosopher." But the reader who has already received some training from Ripley, or from examining his text, will recognize first, that the words "Doo, but not after the common guise," are a hint that he should exercise his hermeneutical skills. Second, he will also recognize that in his words "Sulphures or Salts," Ripley is not opposing these two chemicals to other chemicals, but opposing them, instead, to their other and coded meaning. "Sulphur" is "soul" and "Salt" is "body" or the body's essential physicality. In these three lines, Ripley is teaching his reader to think ontologically and not sensibly. Ripley bases his ambiguities on a complex structure of opposites. There are the horizontal opposites, in which the wrong chemical substance is the opposite of the correct one. But there are also opposite modes in which the words can mean. Ripley's reader must treat words as words. He must dissect language before he puts it back together again. At the same time, however, Ripley is asking the reader to 
"hev[e] up the heved" to "right heye thinges," since he is asking him to lift his head above sensible perception. To divide a thing into body and soul is not a sensible division.

As the reader journeys through the Compound by interpreting it, his mind itself is transformed by being epistemologically dissected and put back together again, since language is thought and thought is mind. The text of the Compound becomes one with the reader's mind. Since it is treated as an object, it is a reification of the reader's mind, just as is the natural stone in the sealed flask. Ripley's alchemical journey, then, radically extroverts, inside-out, the medieval Christian contemplative mind which enacts the journey towards God, as it is presented by Bonaventure. It externalizes this mind into a reified material object "out there." It is this object that performs the journey. At the same time, however, the alchemical journey preserves the contemplative journey's outline and dynamic teleology. It also parallels most of its feature, if not all. But to a large extent, it does so in an inverted way.

In addition to the objectification and spatialization of the journey and to the replacement of the pilgrim's mind with the "stone" as pilgrim, the alchemical journey relocates and pulls down God's power and intervention in Nature from the ineffable beyond into the midst of Nature: God does not need to intervene directly since his laws are already encoded into Nature through the seeds of His Logos-His active traces in the world; and the teleological course of the journey is genetically encoded into these seeds. Nature is rounded off into an autonomously operating system, and the journey of the stone has been largely mechanized. The journey, from its beginning to its fulfillment in the phoenix-like resurrected stone, remains within the bounds of nature, with the divinity paradoxically and enigmatically encapsulated within it. Ripley rounds off Nature into an autonomously functioning world, which has incorporated God's Logos into itself, in part 
like the Jerusalem of the Pearl Poet's Clannesse which gradually incorporates God's laws and His Justice into its inner structures. Although the alchemist's pilgrim-stone does experience the journey's teleological beginning and end as liminal events, as is discussed below, ${ }^{\mathbf{1 6 9}}$ the alchemist stands within Nature, and only perceives the goal of the journey from his intra-cosmic perspective. While the goal of Bonaventure's journey is God Himself, the goal that the alchemist sets for his stone is not God in Himself, but the deified product of the union of his stone with God. His goal, in other words, is the deification of Nature, and of himself by analogy with the artificially perfected natural product of his labor. His stone becomes a figure of the resurrected Man-God, Christ, but specifically resurrected back on Earth as a perfected and deified microcosm. Bonaventure's microcosm has enclosed all of spatio-temporal existence into itself through the doors of its senses and the climb through the intellectual categories of being. It is unified by virtue of its experience of limits, nothing remaining beyond itself but God, and thus relating to God with affective immediacy and with its entire being. Ripley's microcosm, in contrast, is focused on its deified self, and still depicted as spatially enclosed by the macrocosm to which it is analogically related.

Ripley does, like Bonaventure, require his reader to begin his journey with God, yet in spite of that Ripley's Nature has become a self-enclosed and autonomous entity, like the Philosopher's Stone, a macrocosm. But it seems to be in a relationship with itself instead of with something beyond it.

12. Therefore with God looke thou beginne, That he by grace may dwell with thee, So shalt thou best to wisdome winne; And knowledge of our great privitie: Nourish vertues, and from vices flee, And trusting thou wilt thee well dispose,

${ }^{169}$ See pages $35-36$ 
Our secrets to thee I will disclose. (Prol. 12.1-4)

The acquisition of wisdom and "knowledge of our great privitie" depends on God's Grace. Like Chaucer, Ripley uses the word "privitie" to describe the divine secret or "root" of the Stone, as described in the introductory chapter above. But he is not looking, or expecting his reader to look inward. The difference is vast when one compares it with Bonaventure's asking his reader, in the quotation discussed above, to "open your eyes therefore, prick up your spiritual ears, open your lips, and apply your heart, that you may see your God in all creatures, may hear Him, praise Him, love and adore Him, magnify and honor Him, lest the whole world rise against you" (1.15). Ripley advises his reader to "Nourish vertues, and from vices flee," but his gaze is objective, and although thinking of God, he is not seeking Him- especially not seeking Him through the passion and love with which Bonaventure's pilgrim seeks Him. He persistently mentions God in the "Prologue," but his gaze remains within the world:

Dread God therefore and obey his law: A righteous man forsooke I never sawe:

Neyther his seede begge bread for neede: In holy scripture this doe I reede.

Pray God therefore that thou maist finde Wisedome and Prudence with mouth and minde. 4. All manner good come with them shall, And honestie by their hands innumerable, Then into cumbrance shalt thou not fall, So be they in riches incomparable:

To worship and profite they will thee able, To cunning and all manner of grace, Both here and after thy lives space.

5. For these benefites which they doe bring, I meane these vertues of prudence and sapience, ....

That whatsoever earthly precious is, To them is compared as clay Iwis. 6. Infinite treasure to man they be, Who useth them shall friendship have With God in heaven and there him see, 
After them therefore busily crave,

For bodie and soule they will both save,

And here in goods thee multiply;

And afore princes thee dignifie. (Prol. 2.4-6.7)

The advice with which Ripley begins his Prologue looks on the surface like traditional wisdom that would be advanced by any religious person of his time. He tells his disciple that God punishes the sinners and rewards those who "obey his law," and adopt the virtues of "Wisedome and Prudence with mouth and minde" (Prol. 2-3). He also enumerates the rewards and punishments to be expected. In stanza 7 he enumerates examples of losses due to sin, Adam his wisdom, Sampson his might and Saul his kingdom. Absolon hung by a tree, and David and Ezechias got their respective punishments. Like a normal preacher, he does not distinguish what seem to be natural effects or logical outcomes of imprudence and rashness, from supernatural disruptions of nature such as the burning of Sodom with "fire from heaven" (Prol. 10), since, after all, they are all equally brought about by Divine power. Similarly, the rewards range from health and wealth to such supernatural events as Enoch and Hely's bodily rise to heaven (Prol. 8), and the immunity of "Daniel and others in many a place" from "the cruelness / Of Tyrants, Lyons, and of the hot furnace" (Prol. 9).

However, the logic that underlies Ripley's blending of natural with supernatural outcomes is significantly directed at this world rather than the next. It is in a way a reversal of the idea of rewards and punishments in the afterlife. Ripley stresses those in this life:

Dread God therefore and obey his law:

A righteous man forsooke I never sawe:

Neyther his seede begge bread for neede:

In holy scripture this doe I reede. (Prol. 2) 
The effects of virtue he describes are clearly distinguishable from the Christian or Boethian traditions of inner peace or happiness even in the midst of tribulations. God will shower "all manner of grace" on the wise and prudent including escape from poverty and hardship, "worship," "profit" and "cunning." At this point, however, it is important to avoid misunderstanding and to note that although Ripley stresses rewards in this life, he does not do that in any simple way. The rewards in this life are not ends in themselves, and those who seek material things in themselves will be denied these benefits. So, concerning prudence and sapience he explains (Although the quotations I offer sometimes overlap, as they do in the following quotation, I am allowing this overlapping for the convenience of the reader not to have to switch back and forth):

So be they in riches incomparable:

To worship and profite they will thee able, To cunning and all manner of grace, Both here and after thy lives space.

5. For these benefites which they doe bring, I meane these vertues of prudence and sapience, To whome I can compare no thing, No riches, nor spices of redolence, Aboue all treasure such is their excellence, That whatsoever earthly precious is, To them is compared as clay Iwis.

6. Infinite treasure to man they be, Who useth them shall friendship have With God in heaven and there him see, After them therefore busily crave, For bodie and soule they will both save And afore princes thee dignifie And here in goods thee multiply; (Prol. 4-6)

Material benefits are effects of the "infinite treasure" of these virtues, brought about by an attitude that genuinely seeks wisdom above all else. Compared to them earthly treasures are only as clay. They value earthly treasures only in so far as they are a part of 
the union the wisdom-seeker achieves between spirit and matter, and between the divine and earthly mode of existence.

Instead of blending natural with supernatural effects on the basis that both are equally caused by God's will and thus supernaturally ordained, Ripley blends them together on the basis that they are both natural effects, in which God's intervention occurs not directly, but through the seeds of His likeness which are also germs of His wisdom and encode within themselves His laws and his plan for nature. They give matter the potentiality to be spiritualized and united with the soul. Thus a person's Prudence and Sapience "bodie and soule they will both save /And here in goods thee multiply" (the emphases are my own). It is possible, therefore to argue that there is a connection between these "vertues" of the soul and those "vertues" or powers that late medieval authors assigned to natural things, such as the flower-engendering "vertu" in the opening lines of the General Prologue to the Canterbury Tales. The perfection of nature involves the spiritualization of matter as well as the reverse: the fixation of the previously volatile spirit into matter:

Medicine will little profit thee of it self, except it be mingled with a Body, for then shall it perfect its work according to its form which it is born: For it is never born that it may of itself become a Body. Moreover, know that there is as much difference between the first Matter, which is called the Seed of Metals, and the Medicine, as is between the Medicine and Gold: For the Seed will never be the Medicine without Body .... ${ }^{\mathbf{1 7 0}}$

Fixation will give the spirit a body and therefore allow it to participate in God's plan and the salvation and perfection of the world. This allows a person's exercise of "vertue" to save both "bodie and soule," in the here and now. When united with God,

${ }^{170}$ George Ripley, "Treatise of Mercury and the Philosophers' Stone," Aurifontina Chymica: or, a collection of fourteen small treatises concerning the first matter of philosophers, for the discovery of their (hitherto so much concealed) Mercury. Which many have studiously endeavoured to hide, but these to make manifest, for the benefit of Mankind in general. (London, 1680), rp. ed. Adam McLean, the Alchemy Website, n.d., n.p. 
nature does not stop being natural or even physical. Rather it is fulfilled as Nature. Its physical matter remains material, but as transmuted and transcendent matter, fulfilled according to its inbuilt destiny by being spiritualized. The process by which it is spiritualized is a bidirectional process, in which the "ascent" of matter is part of the same action involving the "descent" of the spirit into the matter. This simultaneous process is clearly illustrated in the drawings and poetry of the illustrative work known as the "Ripley Scroll."171 In it the Spirit joined to matter-which in occult alchemy as in Gnosticism, is evil—is depicted as a fall. The union is depicted in the Melusine figure of a woman joined to a satanic dragon, hanging by its tail which is curled around the central branch of the Tree of Knowledge. But the Melusine figure, which is a figure of Hermes as well as of the philosopher's stone, purifies matter and raises it to a spiritual status. Thus a saint's bodily immunity from the burning fire is effected by the perfection of nature through the actualization of the divine seeds within it. Similarly the multiplication Ripley refers to in the seventh line of the sixth stanza quoted above, is the result of the union of the matter with the spirit. This union is the teleological goal already inherent in Nature through the seeds God left in its Prima Materia, and it is the role of the alchemical artist to artificially reproduce the natural conditions for this process, thus instigating and reproducing it in his laboratory. His art works in union with Nature, merely speeding up the processes already encoded within it. In doing so, the alchemist also becomes an agent of divine Grace, as he spiritualizes matter by allowing spirit to enter it and become active within it.

The way God places His divine likeness, which is also "seed" and "virtue" into matter is a complex process that seems to combine God's direct placing of them into the

${ }^{171}$ The Ripley Scroll, Mellon 41 (England, ca. 1570). 
"Prima Materia" of creation with the Neo-platonic theory of emanation, the reception of God's influence by the stars and the subsequent influence of the stars on the things below the moon. For the part concerning emanation and the stars I quote the following lines, which though not written by Ripley, crisply and compactly express the relationship between God, the stars and the rest of creation crisply and compactly. They are from a poem by Sir Edward Kelley published by Ashmole ${ }^{\mathbf{1 7 2}}$ and placed by Stanton Linden among the preliminary material to the Compound. ${ }^{173}$ They refer to the virtues that God placed in the "Skies," or in other words, in the stars, which in turn reflect these virtues back and forth "from and t'everie point":

Example learne of GOD, that plaste the Skies, Reflecting vertues from and t'everie poynt, In which the moover wherein all things lies, Doth hold the vertures all of everie joynt:

And therefore Essence fift may well be said, Conteining all, and yet himselfe a maid. ${ }^{174}$

It is not exactly clear in these lines whether the "moover" that lies within all things comes through the reflection from the stars, or is inherent in these things and activated by the received influences of the stars. I believe the latter meaning to be the correct one and we will return to this point in a later section below. In any case, the First Mover has been distanced a step back from the world, and Nature now contains the little movers within it-the seeds that the First Mover planted when he created the materia prima--that propel it towards its appointed destiny.

Ripley's Compound, however, seems to offer greater emphasis on the seeds that God placed in Nature than on the influence of the stars, although both are implied in its

\footnotetext{
${ }^{172}$ Ashmole, Elias, 1617-1692, ed., Theatrum Chemicum Britannicum: containing severall poeticall pieces of our famous English philosophers, who have written the hermetique mysteries in their owne ancient language (London: Printed by J. Grismond for Nath: Brooke, at the angel in Cornhill, 1652).

${ }^{173}$ Edward Kelley, Sir, "Sr. E. K. concerning the Philosophers Stone, written to his especiall good friend, G. S. Gent," in Linden, George Ripley's Compound of Alchymy, 13.

${ }^{174}$ Ibid. (5.1-6).
} 
language and structure. God's direct placing of the seeds of His likeness in Nature plays a complex and fundamental role in his conception of the alchemical operation. For Ripley as for Bonaventure, God created the world out of nothing and insisted on the Augustinian principle that even potentiality is created by God. Potentiality, according to Ripley, is the first thing that God created in the form of the dark and confused mass of primordial matter - the "prima materia" of the universe. However, as orthodox as this account of creation looks, and as much as it seems to adhere to the doctrine as expounded by the doctors of the Church, such as Augustine, Bonaventure and Aquinas, there is a significant, and even radical difference. As mentioned above, for Bonaventure, who fully adheres to Christian doctrine, as in the Christian interpretation of the biblical books of Wisdom and Ecclestiasticus which Bonaventure's language suggests, ${ }^{175}$ and as in the opening of the Gospel of St. John, God's Word or Wisdom was there with Him prior to creation- prior to any creation, even of the first potentiality. For any of these three theologians, all past present and future are simultaneously present in God's mind and in His eternal but very present moment. In this sense, God's creation was complete and simultaneous. It is only in our minds that we dissect the act of Creation into narrative sequence. Aquinas, for example, insists that God created the actual body from the beginning, and not mere potentiality which he then turned into actuality. Passion cannot come first since it is part of the genus "action": "Passion is an effect of action" (ST, I, Q.44.a2, Reply to Objection 2). "On the contrary, An imperfect effect proves imperfection in the agent. But God is an agent absolutely perfect; wherefore it is said of Him (Dt. 32:4): 'The works of God are perfect.' Therefore the work of His creation was

\footnotetext{
${ }^{175}$ See the discussion of Norton's allusion to the antiphon "O Sapientia" in Chapter Four below.
} 
at no time formless" (ST, I, Q.66.a1). ${ }^{\mathbf{1 7 6}}$ Although there are different opinions among "holy men" on this matter, this difference is shallow and underlain by agreement. Augustine is one of those who also hold the simultaneity of creation: "Augustine for instance (Gen. ad lit. i, 15), believes that the formlessness of matter was not prior in time to its formation, but only in origin or the order of nature" (ST, I, q.66.a1, I answer that).

In contrast, Ripley Christianizes the alchemical narrative of creation, or more accurately the divine production of the Cosmos- - which will serve the alchemical pilgrim as the model and exemplar whose steps he must replicate on his journey-only by changing the Ancient account of a pre-existent and co-eternal primal matter, to a created primal matter. However, the Word, in his account, comes after the primordial chaos. God first created the prima materia out of "nought," then he brought things into "distinction" out of the prima materia, and only then are "heaven and earth . . perfected by his word":

6. In the beginning when thou mad'st all of nought, A globous matter and darke under confusion, By him the beginning marveilously was wrought, Conteyning naturally all things without division: Of which in six dayes he made cleere distinction: As Genesis apertly doth record.

Then heaven and earth were perfected by his word. (Pref. 6.1-7)

Even if one can possibly argue that Ripley really meant to say that God also brought things into “distinction” by His Word, Ripley's account is unambiguously clear about the presence of the prima materia before either the "distinction" or the "perfect[ion] through the Word." The next stanzas affirm this order. In stanza 7 Ripley states that "a principle" "shall come" that will "declar[e]" the stone. This "principle" seems to be the

\footnotetext{
${ }^{176}$ Aquinas argues: "Passion is an effect of action. Hence it is reasonable that the first passive principle [matter] should be the effect of the first active principle, since every imperfect thing is caused by one perfect. For the first principle must be most perfect, as Aristotle says (Metaph. xii, text 40)" (ST, I, Q.44.a2, Reply to Objection 2).
} 
same as the "one Image" of stanza 8, out of which "All our secreats . . . must spring." Christ as Word, in other words, is the hidden 'root' and secret that the alchemist must regress his stone to the prima materia to discover, in order to "perfect" his stone. Christ is the kernel that the hermeneutical pilgrim seeks to disclose and the form he seeks to attain. At the same time, somewhat like Bonaventure, for whom God leaves His "vestigia" in nature and in His creatures, Ripley implies that this "principle" or "Image" is Trinitarian in form and can be discovered hidden in the prima materia, and that it is the formal principle of the microcosm which the stone will become:

7. So through his will and power, out of one mas Confused; was made each thing that being is, But afore in glory as maker he- was, Now is and shall be without-end I wis, And purified soules up to his blis Shall come a principle this may be one, For the declaring of our precious stone.

8. For as of one masse was made all thing, Right so in our practize must it be, All our secreats of one Image must spring, Our stone is called the lesse world, one and three; Magnesa also of sulphure and Mercurie, Proportionate by nature most perfectlie. (Preface, 7.1-8.7)

Although the first matter is "under confusion" and "without division," it was "marveilously wrought" and "conteyn[ed] naturally all things." Since potentiality is created, it already contained the seeds of God's Word, the Logos and principle of individuation, or, more precisely, it was composed of these seeds. In fact, the first matter was not privation but potentiality precisely because it already carried the Word within it. However, there is, again, a problem in Ripley's account of the Word and its Trinitarian configuration. Ripley identifies the form of the Trinity within the seed as "Magnesa also . . sulphure and Mercurie." These three are respectively body, soul and spirit, and at the 
same time Father, Son and Holy Spirit. The Father would be identified with the primal matter in the sense that $\mathrm{He}$ is Creator and the beginning of everything.

As part of Ripley's adaptation of the language of alchemy to Christian doctrine, he, like other Western European alchemists before him, equated the alchemical names for the seed and the stone with the Word. Primary among these names he equated with the Word was Hermes or "Mercury":

as I said before, that Water of Life which is our Seed and first Matter, is our Mercury and our Spirit of Life, which is extracted out of the blessed land of Aethiopia, which is called Magnesia, and by many other names. ${ }^{177}$

In this esoteric and very complex description, Mercury is identified with almost everything, and all stages of the stone's transformation. Since even potentiality is created, the "Seed," like its other names, Mercury, and the "Water [that] is the first Matter of all things," is simultaneously identified with both the initial stone in its state of potentiality, and the fulfilled and "resurrected" stone at the end. "Water will be highest and lowest. Yet true it is, that it is of least estimation, for in our Earth and Water, and in that drossie Earth, you may find some very pure and clear, which is our Seed and fifth Essence." ${ }^{, 178}$ It is both material and spiritual. It is also the soul unifying the two, and it is the beginning, the prima materia, and the end, the completed Stone, fully present, no longer deferred. About this seed, alchemists love to esoterically reiterate that "it," which holds the enigmatic key they need for their operation is everywhere, even in the meanest dirt. ${ }^{179}$ Yet, in spite of the fact that it is "of least estimation" it is also the "fifth essence."

177 George Ripley, "Treatise of Mercury and the Philosophers' Stone.”

${ }^{178}$ Ibid.

${ }^{179}$ Such description of the Stone is part of the alchemical tradition, and continued to be retold and reinterpreted. For example, Johann Ambrosius Siebmacher, in his Sophic Hydrolith," first known to have been published in Frankfurt in 1619, elaborates it as follows: "But by the ignorant and the beginner it is thought to be the vilest and meanest of things.. It is sought by many Sages, and found by few; suspected by those that are far away, and received by those that are near; seen by all, but known by few, as you may see from the following lines: 'Into three the great good is divided, yet it is one, and highly esteemed by the 
Perhaps most puzzlingly, Mercury is identified with the trinity in more than one way. He is both one of the Trinity and at the same time the whole Trinity. As demonstrated in the quote above (Preface, 8.6), Mercury is one of the Trinity, usually Spirit. As Spirit, he unites the sensible image with the rational image. In the last quote above, however, Mercury is "Water of Life which is our Seed and first Matter," as well as the "Spirit of Life" snd Magnesia, extracted from the first matter (the black land of Aethiopia). The alchemical language that refers to the trinity is very fluid and the "names" often exchange places. Mercury, however, is usually the most inclusive one. Mercury is the prima materia, the seed — which is the Trinitarian form itself-and that which is extracted from the prima materia. While he is the extracted "Spirit of Life" (extracted from his own self), he is also the seed, which is the entire Trinitarian "seed" which is usually "soul" and identified with the Word. Mercury is both Christ, the mediator, the seed and soul, and he is also the Green Dragon of the prima materia who is identified with Satan in the "Ripley Scroll" and with hell as shown below (III, 15.6-7). Whichever way Mercury is combined with Christ, whether he is Christ, or united with him, he is in sum a union of good and evil, the divine with the infernal. He is also the result of the perfected union: the Philosopher's Stone. As shown in the earlier chapter, Mercury is both healer and deathly poison. Presumably when the Stone has been purified, and the union is complete, the Philosopher's Stone would have transcended evil. But doesn't it follow that it would also have "transcended" good as well? Regardless of evil and good, however, the Stone seems to be a union of a good God and an evil "matter."

world. Men have it before their eyes, handle it with their hands, yet know it not, though they constantly tread it under their feet. It is the greatest wealth, and he who knows the Art may rival the richest." Arthur Edmund Waite, ed., The Sophic Hydrolith or Water Stone of the Wise, in The Hermetic Museum Restored and Enlarged, 68-120, 77. For further bibliographical information on the "Sophic Hydrolith" see Adam McLean, ed., "The Waterstone of the Wise," The Alchemy Website, http://www.alchemywebsite.com/sophic1.html, Accessed April 8, 2014. 
The duality seems to run deep into the foundations of the Stone's being. While Ripley, like Bonaventure, insists on God having created out of "nought," and the prima materia being created, the result is a creation narrative with a radical difference separating it from Bonaventure's narrative. Bonaventure's microcosm, once it has become fully rounded off into a self-enclosed whole, is clearly and unambiguously engaged in a relationship with a divine existence beyond itself. It becomes rounded off on the basis of that relationship. Ripley's microcosm is self-enclosed, with all of nature and time and space within it. But it has nothing beyond itself to which to relate. God is spiritual and is a part of it, while it unites Him with matter, male with female principles, into its being. Another name for Mercury, "Azoth," is a word deliberately coined to contain the "A" and the "Z," the alpha and the omega. The Alpha-and-the-Omega is itself the Stone, Nature, or Anthropos. ${ }^{180}$ Nothing is beyond it.

Ideally, the discovery of the seed, the fifth essence and Azoth, is no less paradoxical and no less a liminal experience than an encounter with the supernatural beyond. Yet the alchemist conceives of the alpha and the omega of his journey as principles incorporated within nature, and he perceives the limits of the sensible and intelligible world from a point of view within nature as well. Unlike Bonaventure's pilgrim, he does not conceive of his mind accomplishing a passage into the beyond. When his stone transcends itself it has incorporated its encounter with God within itself, but has remained within nature. Like the ouroboros with its tail in its mouth, and like the phoenix which is reborn out of its own ashes, the alchemist's Stone dies and is reborn back into nature. The spiritually fertile nature thus becomes the self-sufficient and

\footnotetext{
180 For the Stone as "Anthropos," see Urszula Szulakowska, Sacrificial Body and the Day of Doom: Alchemy and Apocalyptic Discourse in the Protestant Reformation (Boston: Brill Academic Publishers, 2006).
} 
androgynous "Virgin," Cosmic Egg, as well the child of the "alchemical marriage"described in the Rosarium Philosophorum attributed to Arnold of Villanova—between the active male principle and passive female potentiality on the horizontal plain and between earth and heaven on the vertical plain.

Thus, as enigmatic as it may be, the goal and destiny towards which all things move according to the divine plan encoded within them, is the philosopher's stone which is the perfected and deified state of nature. In other words, the intentional goal is the self as Philosopher's Stone. The alchemist treats nature as rounded off into self-containment, and enclosing within itself the alpha and the omega of being, the teleological beginning and end of existence. The journey has now become spatialized, and the stone, the objective correlative of the mind which has fulfilled the journey, also remains within nature, but as a deified individual body which is spiritualized and fused with the divine likeness within it. The natural Cosmos seems to have become entirely self-sufficient, self-contained and self-directed.

The Divine law that Ripley exhorts his disciple to obey in the lines from the second stanza of the Prologue quoted above, is encoded into nature, and is thus manifest in its laws. One need not only resort to God outside nature to discover and obey them. Indeed, the idea of the Logos manifest in nature is a Christian, Neo-Platonic and even Ancient idea that can be claimed to go back as early as Heraclitus in the $6^{\text {th }}$ to $5^{\text {th }} \mathrm{C}$ BC. Philo of Alexandria, for example, in the first century AD, saw in nature a guide to wisdom. The Preface to the original edition of Young's translation summarizes his attitude as follows:

At the beginning of the first, that on the Creation of the World, he intimates that his object is to show how the law and the world accord with one another, and how the man who lives according to the law is as such a citizen of the world. For Moses, as he remarks in his treatise on the life of 
that prophet, demonstrates in his history that the same Being is the Father and Creator of the universe, and the true lawgiver of the world; and accordingly, that whoever follows his laws is adapting himself to the course of nature To follow Nature is to follow God's Law and living in harmony with the general laws of the universe; while again, the man who transgresses those laws is punished by the operations of nature, such as floods, fire from heaven, and such means. ${ }^{181}$

Ripley, however, had an additional element in his approach: an emphasis on the idea of improving the practical quality of life on earth. To achieve wisdom was closely allied to gaining control over nature, but with strict caution against the possible abuses of the knowledge of the secrets of nature by the ignorant.

Ripley has pulled the scene of God's power down from its traditional location in the supernatural beyond to the vista of nature itself. His chief concern is not with God's direct intervention from above, but with His indirect intervention through His Logos, genetically encoded into nature by means of the seeds of His likeness and Wisdom which He has implanted into the prima materia of the universe in general and found in all the creatures individually. It becomes the task of the alchemical artist and pilgrim on his journey of knowledge and "ascent" towards divine wisdom, to discover the blue-print that the Divine Creator has placed of Himself in Nature, and ascend towards God not directly, but through that blue-print. The blue-print provides him with a liminal form of contact with God akin to Platonic pre-lapsarian remembrance, and he uses his art to weave this divine inspiration into the raw material of his world. As such, art, for Ripley is of the essence of human action. Ripley's attitude helps explain the growing importance of the late-medieval to early modern Art-Nature debates. ${ }^{\mathbf{1 8 2}}$

\footnotetext{
${ }^{181}$ Charles Duke Yonge, ed. and tr., The Works of Philo Judeus (London: George Bell \& Sons, York Street, Covent Garden, 1800), v.

182 See Wiiliam R. Newman, Promethian Ambitions: Alchemy and the Quest to Perfect Nature (the University of Chicago Press, 2004) p.
} 
In the Third Gate, "Of Separation," for example, Ripley advises his disciple to set his manuals aside and allow Nature to take its course. Nature will "not blinn" in transforming the four elemental constituents of the stone into the transcendent fifth essence:

But Seperation manual looke thou set a side, For that pertaines to fooles that little good doth winn, But in our Seperation Nature doth not blinn, Making division of qualities elementall, Into a fift degree till they be turned all. (III. 1, p. 37)

Through his labor the alchemist uncovers these laws with which Providence bound the universe into order, and by means of which He has encoded their teleological direction towards Himself. The alchemist transforms the initial piece of matter with which he begins from a mere object empirically identifiable by its practical function, external shape and relation to other things, into a microcosm that contains the ontological structure of the entire universe. He also refers to the material which he is transforming as a "seed" (or "seeds" on occasion, when he is referring to the masculine and feminine principles within it). While the alchemical artist does use the fire of the furnace, which is the fire of the "Dragon," and place his "glass"—his vessel—on it in parts of his work, he must also depend on the "natural" fire inherent within the seeds themselves. It is by means of their inner fire that they will rot and die so that they can, through their "conjunction," germinate and rise into a new life. In the third gate, it would be wrong to use the literal, or external fire against the inner nature of the stone:

Fire against nature must doe thy bodie woe, This is our Dragon as I thee tell, Fiercely burning as the fire of hell.

16. Fire of nature is the third menstruall, That fire is naturall in each thing; 
17. Therefore make fire thy glasse within,

Which burneth the bodie much more than fire

Elementall, if thou wilt winne

Our secrets according to thy desire:

Then shall thy seeds both rot and spire

By helpe of fire occasionate,

That kindly after they may be seperate.

18. Of Seperation the Gate must thus be wonne,

That furthermore yet thou maist proceed

Towards the Gate of secret Conjunction, .... ( III. 15-18 (p. 40)

Through the stages of its death and resurrection the stone actively rehearses and internalizes the entire ontological structure of creation. The alchemist traces and defines the stages of his stone's transformation not in terms of its changing relationship to other things in the world, and thus in terms of the laws of his own culture or logic, but in terms of universal ontological categories of body, soul and spirit, and in terms of the categorical divisions within them--the four basic elemental constituents of Earth, Water, Air and Fire, and the vegetative, animal and intellectual souls. The stone becomes an embodiment of all of existence gathered together into a microcosm. And in this sense, the alchemist's relationship with the product of his labor-his work of art—becomes an existential rather than a practical one. This may be seen as one explanation that may underlie the constant insistence of alchemical texts on the alchemist's virtue, as in Ripley's advice to his disciple in the Prologue to Dread God therefore and obey his law, and in his satire against false alchemists in the fifth gate, since with a merely materialistic goal the alchemical artist cannot transform his stone into a microcosm.

\section{The Stone's liminal experience and 'passage' through death}


There is undeniable correspondence between the three stages of the contemplative journey and those of the alchemical journey. The similarity may be mere coincidence arisen from the elements that have commonly been assimilated into the Christian Western-European culture. It may be a consciously or partly consciously produced correspondence with the Christian contemplative journey, or it may even be the other way around, as Bonaventure was obviously familiar with alchemical ideas and used some of them in the text of his journey. The fact, however, of the correspondence remains. In any case, like Bonaventure's pilgrim, the alchemist's stone passes through three major stages. Each of them contains a number of steps, and in each, the stone makes a paradoxical and sacrificial passage twice during its journey. In the first stage, the contemplative mind passes from sense impressions to species, and correspondingly the alchemist's piece of base metal — which he conceives of as a sensible and material object instead of a sensible image in the mind - must pass away from itself by fragmentation and dissolution to discover the seed of God's likeness. Both the mind and the stone discover species, and internalize the Logos. Both Bonaventure's "species" and Ripley's version of the species, the "seed," are gifts of Grace. But while for Bonaventure it is in his mind, by means of participatory acts of perception, that the pilgrim receives the gifts that God has sown into nature, for Ripley it is a spatially conceived physical object "out there" which receives the seeds that God has sown. While Nature itself, for Bonaventure, consists of acts of perception in which the pilgrim participates in God's act of sowing, which is part of His act of creation, Nature for Ripley is emphatically material and spatial, and God has sown His seed into its primordial matter at the time He created it.

The first passage through death in the alchemical journey occurs at the beginning, during the first phase, the black or "negredo" phase presided over by the planetary god 
Saturn. To reach the seed, the individual piece of base metal must decompose until it becomes one with the primordial and shapeless prima materia of creation. In other words, the individual piece of metal—and, by analogy, the individual alchemist—must "die" in order to be recreated through the Word. This regression is a death in which the individual piece of base metal, and by analogy the individual mind of the alchemist, loses its superficial or false and worldly shape and definition, in order to discover the true one through the Word. But there its death can only be a paradoxical crossing of infinity. As mentioned in the first section of this chapter, the mind's transformation of sense impressions into species and genera is logically impossible and its occurrence is no less than miraculous, since it is made possible by God who gives his gifts to the pilgrim's mind. The case is similar in the first phase of alchemical transformation. Since the piece of metal has to disintegrate in order to die and join the seed of the divine likeness in the prima materia, there has to be something that will stop it from fragmenting ad infinitum. The nothing into which it would infinitely disintegrate would be pure privation, and the distance between pure privation and pure potentiality is infinite and needs the power of God to overcome it. The alchemist's stone, therefore, must miraculously receive and recognize itself in the seed not by its individual actions alone, but by divine action in which its act of perception participates. In other words it must die to receive the Word through which God creates it, but without God's help it cannot cross the infinity of its divisibility and degeneration, and thus actually die. The distance separating it from the likeness by which it will be created is as infinite as the distance separating the sense impressions from their species in the journey of the mind.

Once the stone discovers itself in the seed, during the black or "negredo" phase, it will be ready to move to the white or albedo phase in which the consummation of the 
"alchemical marriage" (and death) will take place. This second death prepares the stone to pass into the red or rubedo phase, and give birth, through its own phoenix-like death, to the child of the marriage, who will be a figure of Christ, and of Hermes, a perfect microcosm. The child's physical body has been transmuted and deified, thus forming the micrcosmic perfection of nature risen "above itself," to be united with the divine and become the "Philosopher's Stone." This rise corresponds to Bonaventure's contemplative passage into God's all-embracing Love and Peace, in union with the crucified Christ, but with the difference that when it rises above itself it does so back into the world againnow possessed of the power of healing, and able to purify and vivify all that come close to it. During the albedo phase, the stone is more actualized in its differentiation into its male and female principles-which literally are its active and passive, actual and potential, spiritual and material proportions. The alchemist seeks the transcendent golden mean between all his opposites. During "conjunction," which is part of this phase, these parts become internally "married" in two ways: horizontally with each other, and vertically between their material and spiritual parts. They acquire a soul, or in other words a will of their own, and the soul mediates the union between body and spirit, nature and God. The internally married or "conjoined" seed must 'ferment' or in other words die and rot in the soil in order to sprout and produce "Hermes' Tree," which is both the dynamic process and the end-product — a figure of the resurrected Hermes-Christ himself, the self-contained and internally fertile "child" in whose being are fused male and female (horizontally) and matter and spirit (vertically). The marriage and death of the seed in the albedo phase leads to the second and final paradoxical passage through death, and to the third and final stage, the "rebirth" and equivalent of Bonaventure's 
union with God. This is the red (rubedo) stage in which the opus is fulfilled as a microcosm, and has been transmuted into the philosopher's stone, the healing medicine.

There are also important correspondences and contrasts between the two journeys in terms of the language of allegory. While we can find correspondences between Ripley's and Bonaventure's three phases as well as the three modes of meaning Bonaventure describes, the symbolic, literal and mystical, there are also significant and telling differences. Bonaventure's three modes carry a paradoxical identity with each other: In the mind's rise from sensible to intellectual truth, the sensible image is the symbol and the species the literal referent. The mind subsequently rises from the literal species to a mystical and affective mode of knowledge of God-a mode of knowledge that is independent of all conceptual categories. The mind receives divine illumination as He gives Himself to it - the mind thus secures the stability of the phenomena it perceives in nature due to the limits with which God's beyondness has bound them. The pilgrim's world becomes a world of plenitude teeming with color and differentiated beings. In it the species and their sensible symbols are one with the being with which God has illuminated them. Species can bring the phenomena of nature to the pilgrim's perception without being negated by opposition either horizontally, since they derive their identity from above, or vertically, and there are no oppositions to be made against a nonconceptual God who is "known" only mystically and affectively.

Corresponding to Bonaventure's sensible symbol realizing itself as species, the disintegrating piece of base metal realizes itself in the seed and becomes that seed which it has regressed to recover. So Ripley's equivalent to Bonaventure's sensible symbol in the mind, is an externalized and physical piece of metal, which he calls his "stone" and “egg” among several other names. 


\section{Recapitulations}

Ripley states that the alchemist, and by analogy the reader, must start the journey with prayer and perform it through His Grace. He speaks of a Christian God Who transcends the universe, and to attain its divine goal the journeying Stone must "die" as it leaps through death to a divine mode of being. However, there are important features in his work that have significantly changed or even inverted the nature of the journey towards God as exemplified by Bonaventure's Itinerarium. Although, as argued in Chapter Two above, Ripley's reader is ideally an interpreter in a hermeneutic pilgrimage towards the divine referent of his individual intentionality and the Boethian ultimate Good, there is nevertheless a radical change in the pilgrim's attitude: the referent of his intentionality is arguably the Stone rather than God. The human individual, in Ripley's approach, becomes himself the referent, and in a sense, God is put at his service.

There is a bifurcation in the journey between the alchemist's mind and the stone, which is also a split in the alchemist's own being. The stone relates to the alchemistreader in more than one way. In one sense, it is the materia prima, which he as artist is transforming. As such it is part of the physical world which extends from his body. In another sense, it is not merely something in the world, but is the world. In this sense, the stone - the entire material world - is his body. In alchemy the body is female and passive. He, as soul, which is male and active, acts upon it and weaves the referent of his intentionality (spirit) into it.

In Bonaveture's Journey, when the pilgrim is turned towards God (which he exhorts him to do right from the outset) sensible images and rational species-thus words, language, thought and the mind itself-are neither inner nor outer, neither subjects nor objects. They are acts of soul and meeting points between the divine Intellect—which 
is the source of knowledge and which gives itself through Grace-and the pilgrim's mind. The pilgrim's seeking occurs simultatneously with God's creative giving. Through the pilgrim's seeking and God's Grace combined, the pilgrim becomes an agent of God's act of creation. The pilgrim has the freedom to choose to become such an agent. As such, he has the freedom to embrace his own and the world's creation, and to participate with God in realizing it. As shown in the previous chapter, Ripley too thinks of the alchemical pilgrim as an agent of divine Creation. But for him, language and mind have become objectified into the stone. It is possible for one to discern two complementary aspects of this objectification. On the one hand the alchemical pilgrim's mind is the stone "out there" in the world. He can look at it, examine it and dissect it. On the other hand, his mind is the whole spatio-temporal world. But it has become objective. His whole mind is turned inside out into externalized time and space.

The same has happened to language. For example, even as Ripley's pilgrimreader learns that the word "kind" in "Joyne kind to kind" (Compound I.5.1) belongs to more than one epistemological mode of truth and refers to more than one ontological mode of being, language has been objectified for him, and he is dissecting it. He is "separating" it into its epistemological components as a mental exercise. This mental exercise leads his mind on a journey to higher planes of categorical awareness. Ripley seems to be more of a literary critic than a poet. He is distanced from emotional involvement. Ripley is not intent on the experience of the beauty and love that are in Nature and interpreting them for us the way Bonaventure does. Bonaventure experiences the 'Book of God' and then interprets it in his text. In contrast, like a critic, Ripley is interpreting other texts. He is dissecting their language and putting it back together again. The text for him is a tool. Both language and the material world (his body), have 
become tools, and the stone is identified with both. Ripley provides the reader with intellectual tools, but he does not inspire a passionate sort of seeking, as does Bonaventure. Can one seek God—or the Good that is even more than the totality of all the good that one wants and desires—without passion?

For Bonaventure's pilgrim words are located at the mystical sources of motivation and intentionality. Like Adam, he "names" the things as he shares with God the act of bringing them into being. Ripley's reader-pilgrim, in contrast, is dissecting the text of something that has already been made. The text of the Compound has already become separated and fallen away from the act of originary knowledge, in which the author receives divine inspiration and then inscribes it into text. It can be argued that in dissecting the language of the Compound, Ripley's reader-pilgrim is not God's agent first hand. Rather, he is recuperating Ripley's act of divine agency that has preceded his own, as Ripley himself had sought to recuperate the agency of the "olde fathers" when he composed his own text by interpreting theirs. Language has become a thing "out there," to be acted upon.

The reification of language and the mind in the Compound's operation of knowledge, and the exteriorization of the products of man's labor can be seen as an encouragement for the arts and as giving new value to these products. But at the same time this reification causes a bifurcation between subject and object, and ironically runs the risk of undermining the indestructible entitihood that is the fundamental raison d'être of the Stone, and thus the risk of condemning the stone anew to the condition of deferral.

The change that natural philosophy brought to Western European art through alchemy can nevertheless be seen as a crucially important contribution in the field of poetic production. It would be hard, for example to overestimate the importance of the 
dramatic distance it helped the artist to produce between man and his own mind, and thereby to enable the reader or viewer to self-consciously examine his own mind and the structure of its operation, and to repeat those in his art. A crucial factor, however that can determine the success or failure of the stone, lies in the question whether the pilgrimreader is intent only to know his own mind as ultimate goal—and thus will not "hev[e] up the heved" or "entencioun" heyond it, or whether his mind is actually in an attiude of seeking that which is beyond itself. In Bonaventure's Itinerarium the dramatic distance that gathers the mind together into a bounded whole is impossible without the mind being in a relationship with a reality beyond it and immeasurably exceeding it. Without that relationship, things will fall apart.

Ripley's Intentional goal is the secret and hidden divine knowledge which will be used to perfect the Stone. His focus is diverted from union with God, which he treats as a vehicle to his further aim. What he is most interested in describing is the structure of the resultant stone, its perfections and its useful effects in this world. Bonaventure's Intentional goal is love towards creatures is part of the love for God, who is the ultimate receptacle and unifier of love. The love of creatures which is unified by the ultimate referent and receptacle of love, God. Bonaventure returned from the journey, back into the world, a changed person. He, however, does not draw the reader's attention to himself or the qualities he has gained. His focus remains on the love of nature and the experience of union with God. The pilgrim rises through love and wonder. The differentiation of ontological parts is an outcome, and their rounding up and "conjunction" into a unified whole, occur as outcomes of love, just as the trees of Paradise come into being as an outcome of Adam's divinely inspired naming of them. Adam does not start by differentiating between opposites, deciding which pairs of opposites he needs in order to 
design a tree to his liking. The text through which Bonaventure performs his journey is God's Word. He recuperates his own being by seeking God beyond it. After he has completed the journey he transforms it into text and shares it with other people the same way as Augustine's holy men interpret God's Word to others in human language.

Both Bonaventure and Ripley are analyzing and putting back together a journey that is already completed. But Bonaventure is examining the sense of wonder he felt, which is neither inner not outer, while Ripley is examining the "Stone." Nevertheless, both are similar in that both, unlike Adam in Paradise, are fallen and are infinitely separated from God by death. Both Ripley and Bonaventure must die, and cross with Christ an uncrossable and absolute no-man's-land of non-being between themselves and God. 


\title{
Chapter Four
}

\section{The Beginning, the End, and the "Meen Space" (Part I): Thomas Norton's Ordinal}

\author{
Incipit
}

To produce a Philosopher's Stone, the alchemist's primary aim is to overcome fragmentation, and to form a complete microcosm- a whole, self-enclosed and indestructible unit, a true and unequivocal entity and person. To do so, he must unambiguously traverse with his stone the entire distance from the beginning, through the middle, to the end. This is a feat impossible for those "botirflyes" whose minds are absorbed in the flux of the sensible world:

Late such like botirflyes wandir \& passe, And lerne this latyne both more \& lasse, Folowinge the sentence of this holy letter: Attingens a fine vsque ad finem fortiter \& disponens omnia suaviter;

That is, procede myghtly to the ende Fro the begynnynge, magre the fende, All thyngis disposinge in the meen space With grete suauyte that comyth of grace. (Thomas Norton, Ordinal of Alchemy, VI, $2719-26)^{183}$

Traversing the distance from beginning to end is necessary, since to form a unified microcosm the Stone must enact temporally, and as such, narratively, the structure it will possess as a unified "whole." To do so it must have an unambiguous point from which to begin, another such point at which to end, and it must be able to traverse the distance in between. As Aristotle argues,

A whole is that which has a beginning, a middle, and an end. (Aristotle, Poetics vii, $3)^{184}$

\footnotetext{
${ }^{183}$ Reidy, Thomas Norton's Ordinal of Alchemy, 84-85.

${ }^{184}$ S. H. Butcher, ed. and tr., The Poetics of Aristotle edited with critical notes and a translation by $S . H$. Butcher (New York: MacMillan and Co., Ltd. (1902), p. 31.
} 
But to traverse the distance can only be accomplished "magre the fende," since it is logically impossible to accomplish, due to the relativity which qualifies the infinity of the spatiotemporal medium through which motion must take place:

Zénon! Cruel Zénon! Zénon d'Elée!

M'as-tu percé de cette flèche ailée

Qui vibre, vole, et qui ne vole pas!

Le son m'enfante et la flèche me tue!

Ah! Le Soleil... Quelle ombre de tortue

Pour l'âme, Achille immobile à grands pas!

(Valéry, "Le Cimetière marin," 1933) ${ }^{\mathbf{1 8 5}}$

If, as Zeno has demonstrated, within the infinity of time and space one point is no different than another, and if each point or section is infinitely divisible so that no "point" can even be, let alone be grasped, and Achilles can never overtake the turtle or reach his goal, how can we legitimately speak of "transformation"? How can one unequivocally designate a point of beginning for one's journey? How can one connect one's motivational spark with the goal of one's seeking, and as such one's beginning to one's end to form a sphere and a whole? The human condition is as Alcmaeon describes it:

Alcmaeon says that the reason why men die is that they cannot join the beginning to the end. [Aristotle (attributed) Problemata xvii. 3] ${ }^{186}$

How can one transform the infinite regress of sequential time, make it bend, turn back and return to its origin to form a full circle, "make ends meet," and make of one's life a spherical and self-enclosed microcosm, a Philosopher's Stone and a "whole"?

\footnotetext{
185 Paul Valéry, Oevres (Paris: Gallimard, 1969), 1503-4.

${ }^{186}$ Artistotle and Robert Mayhew, trans., Problems, Volume I, Books 1-19 (Harvard University Press, 2011), Book XVII. 3, 509-511.
} 
Thomas Norton's Ordinal of Alchemy, like George Ripley's Compound of Alchemy, adheres to the hermeneutic tradition of alchemical literature, and typically veils alchemy's secret knowledge even though this veiling is not as obvious. Norton's language seems far easier to read than Ripley's, since he largely avoides the mythological and occult terminology of alchemy and the elaborately coded names of its substances. Nevertheless, even as he introduced a more literal and as such 'scientific' style into alchemical literature, he simultaneously introduced new ways and nuances of veiling the secret alchemical knowledge he was imparting even while similarly claiming to disclose it. The structures hidden in his language are linked more directly to philosophical rather than mystical texts. Mystical texts such as Arnold of Villanova's Rosarium Philosophorum, Aurora Consurgens, the commentary on "Senior"'s (Ibn Umail's) poem "The Letter from the Sun to the Moon," entitled "The Silvery Water and the Starry Earth ${ }^{\mathbf{1 8 7}}$ the Testament of Moreinus Romanus, ${ }^{\mathbf{1 8 8}}$ — which Norton mentions more than once - the Hermetic Poimandres and the rest of the Hermetic corpus, continue to be important in understanding important dimensions of the alchemical "knowledge" which Norton both discloses and conceales. But Norton seems to have shifted to the less occult and more rationally inscribed aspect of the alchemical tradition, at least in the way his language compares with Ripley's. He particularly shifts towards natural philosophy,

\footnotetext{
${ }^{187}$ See Persis Berlekamp, "Painting as Persuasion: A Visual Defense of Alchemy in an Islamic Manuscript of the Mongol Period," Muqarnas, vol. 20 (2003): 35-59. See also The Great Vision of Muhammad Ibn Umail (Los Angeles: C.G. Jung Institute of Los Angeles, 2003).

${ }^{188}$ Lee Stavenhagen, ed., and tr., ,A Testament of Alchemy (Hanover, New Hampshire: University Press of New England, 1974), translated and edited from the original Latin: Morieni Romani, Quondam Eremitae Hierosolymitani, de transfiguratione metallorum, et occulta, summagqu antiquorum Philosophorum medicina, Libellus, nusquam hactenus in lucem editus [Booklet of Morienus Romanus, of old the Hermit of Jerusalem, on the Transfiguration of the Metals and the Whole of the Ancient Philosophers' Occult Arts, Never Before Published] Being the Revelations of Morienus to Khalid Ibn Yazid Ibn Mu'Awiyya, King of the Arabs of the Divine Secrets of the Magisterium and Accomplishment of the Alchemical Art, translated from the Arabic by Robertus Castrenis, 1182 (Paris: Gulielmum Guillard, 1559).
} 
referring to alchemy as "magyke naturall" $(\mathrm{V}, 1688)$. The textual past which Norton was reconfiguring in his Ordinal was more directly philosophical, which is also to say more directly literal and as such 'scientific'. Nevertheless, his reader should not be deceived by the more literal surface of his language. Although indeed there are abstruse passages, the literal smoothness of his language for the most part, compared to the much more esoteric and obviously aporetic language of the Compound, can easily trick the reader into sliding over the surface without appreciating the hermeneutic architecture of reading his Ordinal offers. His language is dense with textual inter-relations and philosophical structures that can be easily overlooked unless one takes the text more seriously than what its vernacular immediacy seems to call for, unless he is willing to engage with the texts and philosophers to whom it refers.

As the Introductory Chapter has claimed, Norton exhibits awareness that Chaucer was interested in the problem of infinite deferral within the temporal mode of perception. In Norton's third chapter he partially quotes the verses in which Chaucer refers to the infinite deferral of meaning, in the passage quoted above from the concluding part of his Canon Yeoman's Tale. Norton renders it as follows:

Hire name is Magnesia, few peple hir know; She is fownd in hye placis as wel as in lowe. Plato knew hir propertie, \& callid hir bi hir name And chawcer rehersith how titanos is the same, In the Canon his tale, saynge: whate is thuse But Quod Ignotum per magis ignocius? That is to say, whate may this be But vnknow bi more vnknow named is she ? (III, 1158-1165)

"Vnknow bi more vnknow named is she," partly because alchemical authors are careful to veil it, but also partly because language cannot express it. It is the knowledge of God. Norton proceeds to separate the word "Magnesia," the mystical "root" of the Stone into 
parts, and give each a coded meaning. "Magos" is Greek ("grue"), and in "latyne" it is "mirabile," "miraculous."

Magos is grue, mirabile in latyne it is, Es in money, ycos science, $\mathrm{A}$ is god $\mathrm{i}$-wis.

That is to say it is suche a thinge wherin of monay is wondire dyvyne connyng. Now here ye know whate is Magnesia, Res eris in qua latent sciencia diuinaque mira. (III, 1168-1173)

But, a part of "Magnesia" also means "money." The effect of mixing "money" with God is striking and strange. It should alert the reader that either something is wrong, or there is a hidden meaning, and by interpreting, Norton is also veiling. A is the "Alpha," and so it is God. But it is the last letter of "Magnesia" (the second "a" is already used in "Magos"), which renders "Magnesia" end at the beginning. So we are to conclude that Magnesia is circular, and that it ends and begins in God. At the same time Magnesia, which in alchemy is the "name" of the "root" of the alchemical operation, the hidden seed, is located in the prima materia, the primal chaos that in alchemy is the Green Dragon, and is both the beginning and end of the operation. Norton is also saying that is miraculous and a miraculous divine science ("sciencia diuinaque mira"). It is knowledge that belongs to God, rather than to human beings. But how does "money" fit? Is he saying the secret of alchemical money is divine knowledge and belongs with God? Or is there a trick in the words "money" and "monay," or in "Es," and in "Res eris"? Why did he miss the letter "n" in "Magnesia" so that the word is "nes" rather than "es"? "nescio" in Latin is "to be ignorant." Is there a play on sensible money for the ignorant and spiritual money for the wise? Waite interprets "res eris" as "res aeris," refer to airy things. Air is the element identified with "soul" and sometimes with "spirit." It is invariably identified with mind. Hermes' "Tabula Smaragdina" says that the stone is

\footnotetext{
${ }^{189}$ Waite, The Hermetic Museum restored and enlarged, vol. II, 31
} 
born in the belly of Air. In total, the resulting effect is that Norton is deferring the meaning, but at the same time resolving it in God. He also is containing Magnesia, the beginning and end of the alchemical operation, between the Alpha And Omega that are God, since "A is god i-wis." Magnesia, then, from its beginning to its end, is also the middle of the operation. In this way, Norton contains the entire alchemical operation rooted in pagan natural philosophy, within a Christian trajectory that begins prior to the prima materia - the primal chaos and Green Dragon - and posterior to the Cosmos, whether macro- or micro- that is the product of the operation. He places, in other words, the alchemical "generation" of the cosmos within the context of God's "creation" of it out of nothing but His own Act of Creation.

If Waite is correct in his interpretation of "res eris" as "res aeris," then Norton is not only placing in the middle, but also identifying it with the alchemist's — and his stone's-mind. Air is given special importance in alchemical texts, and is in a sense the golden mean of the entire operation. Its bottom half, during the process, becomes united with water, and its top half with fire. These are spirit and soul, whose marriage is the "white" phase of the operation and alchemical marriage. Their union is Air as golden mean.

As we shall see, below, Norton anchors the alchemical operation in the Incarnation as its beginning and end, and the one that is inherent in its middle and making it possible. 


\section{Poetics of the Incarnation}

In Poetics of the Incarnation, ${ }^{\mathbf{1 9 0}}$ Cristina Maria Cervone studies the way several late fourteenth century texts, including Langland's Piers Plowman, incorporate the "topos of the "leaps of Christ""191 into their language as a formal principle and the way they use their resultant formal structure to invest their language with the "capacity to express more than its says." ${ }^{192}$ She introduces the topos of Christ's 'leap' from divinity to humanity and from eternity into time, with Langland's reference to it in the C version of Piers

\section{Plowman:}

For the hey holi gost hevene shal tocleue

And loue shal lepe out aftur into bis lowe erthe

And clennesse shal cach hit and clerkes shollen hit fynde:

Pastores loquebantur ad inuicem etc. $(14.84-86 a)^{\mathbf{1 9 3}}$

Christ's Incarnation, passion, Harrowing of Hell, and Resurrection are all treated as part of the "leap" topos in the texts she discusses, and often the same incident simultaneously refers to more than one of these events, identifying them with each other. "Incarnational poetics" is "a kind of writing that advances for both writers and readers a way of endeavoring to know by means of that structural form." She describes "incarnational poetics" as having a "circling or spiral feel," since the structural form is a dynamic "process," and the "ideational" meaning that is understood through it does not "transcend or supplant it..194 Cervone argues that her book fills a gap in scholarship, since while

\footnotetext{
${ }^{190}$ Cristina Maria Cervone, Poetics of the Incarnation: Middle English writing and the leap of love (Philadelphia: University of Pennsylvania Press, 2012).

${ }^{191}$ Ibid., p. 2.

${ }^{192}$ Ibid., p. 4.

${ }^{193}$ Ibid. p. 2, quoting George Russell and George Kane, eds., Piers Plowman: The C Version. Will's Visions of Piers Plowman, Do-Well, Do-Better and Do-Best, in George Kane, ed., Piers Plowman: The Three Versions, (London: Athlone, 1997). Line 86 quotes Luke 2:15. Cervone quotes the Douay-Rheims translation as follows: "'the shepherds said to one another: [Let us go over to Bethlehem, and let us see this word that is come to pass, which the Lord hath showed us]'."

${ }^{194}$ Ibid. p. 4
} 
scholars recognize "the importance of the Incarnation in late medieval English writing," they have not yet considered "the extent of its influence." 195

As this chapter is concerned with the temporal and narrative aspect of alchemical transformation in fifteenth century Thomas Norton's Ordinal of Alchemy, it addresses another, perhaps even more fundamental, gap in medieval literary scholarship. It gives attention to the medieval poet's serious engagement with the philosophical problem he inherited from Ancient philosophy, of the logical impossibility of identity, entitihood, personhood, definitive event, meaningful 'transformation', and as such meaningful narrative, within an infinite matrix of temporal flux. On these grounds, and through analysis of the Ordinal in particular, this study advances the late medieval concept of art as fundamentally shaped by what the author believed made entitihood, personhood, and "microcosm"- the building blocks of reality—possible. When the alchemist referred to the mystical "root" of "magnesia" he was referring to the fundamental principle that preserved "being" though change. The Christian author also sought the "root" of entitihood, but he sought it in the Incarnation, and all the events of sacred History that were part of what Cristina Maria Cervone described as the "topos of the leap." This, to him was the "leap" of divine Wisdom to earth.

While the medieval poet's Platonic contempt, often ambiguous, for the material and sensible world and its state of flux, has been a commonplace of scholarly attention, the medieval author's engagement with the deeper complex intellectual concepts that underlie this contempt, has been neglected. New and possibly consequential light may be shed on many medieval literary and poetic texts when one takes into account the deep medieval interest in and responses to such topics as the implications of an absolutized

\footnotetext{
${ }^{195}$ Ibid. p. 2
} 
spatio-temporal world without beginning or end, versus a world that is categorically "gathered together" into a formal whole with a liminal beginning and end. Discussions and debates about a beginningless versus a finite world abounded during the middle Ages, as well as discussions of infinity, the void—or what Norton refers to as the "vacuo" versus the "pleno" (V, 1686) - and a created versus an uncreated primal chaos. ${ }^{196}$

The translation into Latin of Aristotle as filtered through translations from Arabic texts and through Averroes' (Ibn Rushd, 1126-1198) Arabic commentaries, during the $12^{\text {th }}$ C. ${ }^{197}$ gave new impetus to counteractive medieval Christian arguments, such as against Averroes' collective intellect and co-eternal world. Ralph McInerny states that "almost the entire Aristotelian corpus was available in the West when the thirteenth century began," although "the versions of the Metaphysics and Nicomachean Ethics were partial ones." 198 He remarks that William of Moerbeke's thirteenth century translation of Aristotle's works directly from Greek, resulted in "an Aristotle who had been freed"

\footnotetext{
${ }^{196}$ See Pierre Duhem, Medieval Cosmology: Theories of Infinity, Place, Time, Void, and the Plurality of Worlds, tr. Roger Ariew (University of Chicago Press, Aug 15, 1987); Benjamin Brown, "Bonaventure on the Impossibility of a Beginningless World: Why the Traversal Argument Works" American Catholic Philosophical Quarterly vol 79, Issue 3 (Summer 2005): 389-409; Richard C. Dales, Medieval Discussions of the Eternity of the World (Leiden: Brill Archive, 1990); Rein Undusk, "Infinity on the Threshold of Christianity: The Emergence of a Positive Concept out of Negativity," TRAMES: A Journal of the Humanities and Social Sciences 13, (63/58) 4, (2009): 307-340; Rein Undusk, "Faith and Reason: Charting the Medieval Concept of the Infinite," TRAMES: A Journal of the Humanities \& Social Sciences 16, Issue 1 (2012): 3-45; Neil Lewis, "Robert Grosseteste," The Stanford Encyclopedia of Philosophy (Summer 2013), Edward N. Zalta (ed.), http://plato.stanford.edu/archives/sum2013/entries/grosseteste/. An article by David Sedley,"Two Conceptions of Vacuum," Phronesis, Vol. 27, No. 2 (1982), pp. 175-193, is only concerned with the Ancient and Classical concept of vacuum, but can be helpful towards understanding medieval attitudes relevant to this topic.

${ }^{197}$ Many of the works of Aristotle, including his Posterior Analytics, Physics, On the Heavens, On Generation and Corruption, and Meteorology were translated from Arabic by Gerard of Cremona (c. 11141187). See Edward Grant A Source Book in Medieval Science, (Cambridge: Harvard Univ. Press, 1974), 35-8, and Charles Burnett, "The Coherence of the Arabic-Latin Translation Program in Toledo in the Twelfth Century," Science in Context, 14 (2001), 249-288, 275-281.

${ }^{198}$ Ralph McInerny, "The Thirteenth Century: translations," np. http://www3.nd.edu/Departments/Maritain/etext/hwp215.htm, accessed 20 Feb. 2014.
} 
from the interpretation of the Arabic commentators. ${ }^{199}$ Even thirteenth century "Aristotle," however, continued to claim a beginningless world, although Aquinas argued that he had claimed it only relatively and not absolutely (ST, I, Q46.A1, in "I answer that"). Although Aristotle, like Plato, allowed a primordial chaos to pre-exist Creation, his philosophy itself contained powerful elements that medieval authors could use in their rebuttal against this same notion. Aristotle contained time and space into intellectual limits as intellectually bounded categories, argued against their ontological absoluteness, and claimed that the ontological sum total of a human being exceeded these categories. Aristotle distinguished between the concept of the primal chaos as a spatio-temporal infinity, and thus as "privation" (which would be an apeiron), on the one hand, and its capacity as the "potentiality" from which the Cosmos is generated, on the other hand. His Metaphysics and Physics brought with them a new medieval conversation with the concerns of the Pre-Socratic philosophers, such as whether the elements which constituted the natural universe were finite or infinite, or whether Heraclitus was right or wrong in judging that what was cold was also hot, and what is, also is not. Although Plato had claimed in the Timaeus that 'God' created time, he had in fact, as Boethius claimed, ${ }^{\mathbf{2 0 0}}$ posited an infinity of time, since what God created was "a moving image of eternity" which was "moving according to number." Eternity possessed wholeness, but time did not (Timaeus, 37a, d). ${ }^{\mathbf{2 0 1}}$ The re-introduction of Aristotle also brought back Zeno's and Heraclitus' paradigms of infinity and relativity. Heraclitus' statement about the river into which one cannot put one's foot twice, was well known.

\footnotetext{
199 Ibid.

${ }^{200}$ Boethius implies that Plato's infinite time was only limited to its modality, and not absolute. Chaucer's Boece states: "For this ilke infinit moevyng of temporel thinges folweth this presentarie estat of the lif inmoevable; ..." (Boece V, p. 6.69).

${ }^{201}$ Robin Watefield tr., and Andrew Gregory, intr. and notes, Plato: Timaeus and Critias, (Oxford: Oxford University Press, 2008), 25.
} 
Alchemy came to Western Europe in the same way as - and in tandem withAristotle, through the translation movement of the eleventh to the turn of the fourteenth centuries, mostly from Arabic. It, too, was most fundamentally concerned with what constituted entitihood and what made it possible for a particular entity to retain its identity through the entire course of its transformation from 'brazen' to 'golden'.

As argued in the introductory chapter above, lack of sufficient scholarly attention to the depth of the medieval author's concern with the problem of fragmentation and deferral within a spatio-temporal infinity, and to the ways he represented it in his literature, can cause some serious blind spots in our reading and analysis of this literature. This study of Norton's concern with the problem of deferral and the healing he offered through the Philosopher's Stone is divided into two chapters. The first chapter, the present one, discusses Norton's presentation of the theme of deferral and healing. The second chapter, Chapter Five, returns back in intellectual history to Pre-Socratic natural philosophy to investigate, in a radical way, the foundations of what is usually perceived as the medieval "contempt" for the sensible world, and the issues involved in Norton's project of harmonizing the Ancient trajectory of "generation" with the Christian one of "creation."

The present chapter argues three important points that are intricately interwoven together in Norton's Ordinal:

The first is the Ordinal's "Chaucerian" concern with and solution to the problem of deferral, as described in the Introductory Chapter above. For Norton as for Ripley, the alchemist's primary goal is to create a "Stone" which overcomes the tendency of things to fall apart. He attributes the condition of deferral in the English people's lives to their 
immersion in the sensible mode of perception, and their consequent subjection to the relativity and fragmentation of an infinite spatio-temporal world without.

The second is Norton's medieval perception of the Incarnation-the "leap" of Christ, as God's "Word" or "Wisdom," into nature, time and human language-as a formal principle, imperative for transforming the infinitely receding and infinitely divisible flow of time, space, language and even thought into meaningful sequence or narrative form that is at once temporal and yet whole. Norton gave a beginning and end to the alchemist's "werke" by anchoring them in the "leap" events of Creation and deathand-Resurrection respectively. He thus placed the origin and destination of man's "werke" in God, thereby giving a circular shape to it, and the constant superstratum it needs for the preservation of its identity through change.

The third and most inclusive claim this chapter makes, is that Norton intended his "Ordinal" as a project of organizing and harmoniously aligning, along the same transformative and redemptive trajectory, the various operations contributing to being as a whole: natural or 'cosmic', sacred, political, personal, artistic or poetic, educational and epistemological. He intended his "Ordinal" to convey, to the alert and sharp-witted reader the hidden and unifying trajectory that underlay all aspects and modes of operation that shaped and defined the life of the human individual, with special emphasis on the contemporary English individual, and the English body-politic ideally united in the person of the King. This chapter brings attention to the fact that Norton sought to accomplish this mighty feat of concordance and harmony, through the humble medium of the English vernacular, thus reaching down to the lay heart of the English language and transforming it into gold. 
In connection with this chapter's third claim as well, Norton sought to align and attach these operations together along a unified trajectory of redemption, and to do that by attaching all to the same formal principle, or 'root,' namely divine Wisdom, to whose leap down to earth Norton alludes in "this latyne" (VI, 2722) quoted in the incipit above. The Ordinal helped heal and initiate the individual reader into a new life by putting him in contact with this unifying formal principle, divine wisdom.

Like, Ripley, as shown in the previous two chapters, Norton similarly gave death a crucial role in the formation of the Philosopher's Stone. The Stone must incorporate the experience of death into its inner structure, if it is to successfully resist disintegration and withstand the "test by fire." The successful Stone transformed death from a state of nonbeing into a finite event and a passage across boundaries, to a higher mode of being and knowledge. But to reduce the infinity of the spatio-temporal world into a bounded category, and "heave up the head" above it into another mode of perception and being, the Stone must accomplish no less a feat than to overcome infinity itself, which is impossible for it to do by its own powers. Norton introduces the Incarnation or "leap" topos - the leap of Wisdom into time - as the key to the alchemist's ability to be "stable of mynde" (VI, 2708) and to proceed successfully from the beginning to the end of the "werke" through the "meen space" (VI, 2725). As Cristina Maria Cervone has demonstrated, medieval literature often joined Christ's death and Resurrection to his Incarnation as part of the "topos of the 'leap'," and part of the same bridge which Christ built through his humanity, between earth and heaven. As a result of the alchemical operation which is anchored in divine Wisdom, or the leap topos, becomes circular, since it both begins and ends in Wisdom: "For the initial causes of things done are the ends to 
which the things done are means." ${ }^{202}$ The initiating motivation is also the end-goal, and the temporal seeking becomes the middle between a beginning and an end that are distinct from the temporal modality of the middle. A mind which "lerne[s] this latyne" and rises with Christ into eternity, transforms the middle into a whole with a beginning and end. This is to say, it transforms the work, including its beginning, middle and end, into a microcosm. This microcosm transcends time even while being rooted in it, just as the tree of life, rooted in earth, fructifies in heaven, and just as Christ's body was born in history but resurrects with him and remains part of him in eternity.

In contrast, the "botirflye" sort of seekers who have not incorporated "this latyne" into their perception, who remain entirely immersed in time and who "for oon monthe haue full byleve, / The nexte month thei will ye arte repreve (VI, 2715-16), will not recognize the depth and transcendence of their own intentional motivation or of the 'Work'. A "botirflye" will not be able to make a true and unequivocal connection between the partial goods or practical purposes which define his temporal praxis, and the transcendent and divine goal which comprehends all goals and which he intentionally and ultimately desires. He therefore will not be able to connect his 'end' to his beginning. Instead, he will be caught in a condition of infinite deferral, and infinite equivocation between his intentionality and the practical purposes and partial goals into which he interprets it.

I argue that Norton sincerely sought to overcome the differences between them by lifting the Pre-Socratic trajectory out of its beginning and end in a duality of good and evil, and place it within the wider and ontologically comprehensive context of Christian

\footnotetext{
${ }^{202}$ Aristotle, in his discussion of prudence, or "practical wisdom" in Nicomachean Ethics VI,1140b.18. For the Ethics I have used Leonard Hugh Graham Greenwood, ed. and tr., .Aristotle Nicomachean ethics: Book six, with essays, notes, and translation, (Cambridge: Cambridge, University press, 1909).
} 
"creation." To what degree he succeeds I do not bring to a definite conclusion, but leave to the reader and to evidence from further future research.

\section{Deferral, the "Ordinal" and the King}

Norton quotes the two middle lines of the four line antiphon "O Sapientia" in the context of advising his initiate alchemist to "lerne this latyne" (2534) if he is to accomplish the "werke," and if he is to be more than one of those "botirflyes"(2719), "[un]stable of mynde" (2708), which "wandir \& passe" (2719). This passage, the implications of which I discuss below, alludes to three texts. The first of the three texts, mentioned above, "O Sapientia," and the rest of the original seven early medieval, "O" antiphons of which it is a part, were assigned, since the time of St. Gregory the Great and his envoy to England, Augustine of Canterbury, ${ }^{\mathbf{2 0 3}}$ each in turn, to the last seven days of advent before Christmas Eve. Norton's allusion to "O Sapientia," and through it to the liturgy in which it is sung, confirms and supports his idea of his poem as an "ordinal." "An ordinal in the Middle Ages" as defined by Beal's "Dictionary of English Manuscript

\footnotetext{
${ }^{203}$ Thurston believes that there is "no valid reason for regarding them as posterior to the rest of the Roman Antiphonary or to the time of Pope Gregory himself," Thurston, The Great Antiphons, Heralds of Christmas in The Month (Dec., 1905), 616-631; cf. Hugh Thomas Henry "O Antiphons," Catholic Encyclopedia 11 (1913). Susan Rankin states that English chant traditions begin with Augustine's arrival in Canterbury as an envoy of Pope Gregory in 597, and that Rome remained the main influence on this tradition until at least the middle of the eighth century, in Susan Rankin, "The liturgical background of the Old English Advent lyrics: a reappraisal," Learning and Literature in Anglo-Saxon England: Studies Presented to Peter Clemoes on the Occasion of his Sixty-Fifth Birthday, eds., Michael Lapidge and Helmut Gneus (Cambridge: Cambridge University Press, 1985), 317-37, 318-19. Edward Burgert states that the "Seven Universal O's" are "first found in the Liber Responsalis of St. Gregory the Great" (Migne, P.L., 78, 732 f.)., in Edward Burgert The Dependence of Part I of Cynewulf's Christ Upon the Antiphonary (J.D. Milans \& Sons, 1921), 61. Susan Rankin cautions of the uncertainty of that origin. She argues that "it is unclear what relationship the earliest extant chant-books (of the late eighth and ninth centuries) bear to the work of St Gregory the Great" (p. 318). The earliest "chant-book," dating from the middle of the $9^{\text {th }}$ C., and referred to by earlier scholars as St. Gregory's Liber Responsorialis actually comes from the Compiegne Antiphoner which Migne published in his Patrologia Latina as part of St. Gregory's complete works: Sancti Gregorii Papae I: Opera Omnia, vols. IV, 733-878, and PL 78 (Paris, 1705), cols. 725-850. The antiphoner is available at the Patrologia Latina database: Sancti Gregorii Magni Romani Pontificis Liber Responsalis Sive Antiphonarius. In Nomine Domini Jesu Christi. Incipiunt Responsoria, Sive Antiphonae Per Anni Circulum. Patrologia Latina Vol. 78. The Patrologia Latina Database, 1996-2014. Although Rankin holds that the Compiegne Antiphoner "does not at all reflect Roman usage at the time of Gregory, or contemporary English usage," this reflects the taste of Charles the Bald, for whom it is believed to have been prepared (rather than the character of its original authors).
} 
Terminology 1450-2000, "was a type of service book containing directions for the order of services, usually for the clergy celebrating the liturgy." ${ }^{\text {204 }}$ An ordinal organized the services and their liturgical content to conform to the sacred order of the hours within the diurnal cycle, the days within the weekly cycle, and the months and seasons within the cycle of the year. It guarded the concordance between the natural or cosmic cycles and the sacred history of mankind - the inclusive culmination of the created cosmos--from the Creation (which is the act of eternal Wisdom creating History, and which constitutes the boundary and meeting point between time and eternity) through the fall (which is man's forgetfulness of that boundary and meeting point, causing him to lose form and entitihood, as he indulges in the medias-res of temporality in which there is no beginning or end) through the Incarnation (which brings the beginning and end into the midst of time, stems the boundlessness and breaks the tyrannical absoluteness of the human condition) and man's latching onto Christ, turning the bend and starting on his journey back towards his Creator, and finally through death and Resurrection (which prefigures the end of the world and the resurrection of the dead). The ordinal, in other words, joined all the operations of Nature in its entirety to the cyclical beginning and end of sacred History, and thus "to the ende/ fro the beginnynge" (VI, 2723-24) in their most utterly ultimate sense. The structure and language of Norton's Ordinal, particularly chapters 5 to 7, indicates that he conceived of it, by analogy with the ecclesiastical ordinal, as a concordance between the temporal process or stages of alchemical transformation, and those above mentioned processes. As shown in a passage discussed below, he, in fact, directly states, in his introductory "Prohemium," that his Ordinal will have an "orderliye"

\footnotetext{
${ }^{204}$ Peter Beal, A Dictionary of English Manuscript Terminology 1450-2000 (Oxford: Oxford University Press, Online Version: 2012, print publication date: 2008).
} 
effect on the alchemist's understanding and performance of the alchemical operation, just "like as the Ordinalle to prestis settith owte/ The seruyce of the dayes as pei go abowte" (129-30). It is significant to note the cyclicality to which Norton alludes in "as pei go abowte," since an ordinal aligns sacred history with the cyclical liturgical year and aligns communal and personal devotion to the cycles of nature from the widest to the narrowest, even down to the "book of the hours." The Dictionary of English Manuscript Terminology 1450-2000 adds that "ordinal" also referred to "the form of service for the ordination of priests and deacons and for the consecration of bishops," particularly in post reformation England. ${ }^{205}$ This implies that Norton would have also conceived of his Ordinal as providing a liturgical initiation for his reader into the sanctity of the state of alchemical wisdom.

In the "Prohemium" Norton presents alchemy as a "most profunde philosophie" (53), and calls it "The subtile science of holi Alchymye;/ Of which science here I entende to write"( 54-55) Like Ripley, and in keeping with what was becoming an established alchemical convention, he opens the "Prohemium" with an invocation of the Holy Trinity, by dedicating "this boke" to "the honour of god oon in persones pree" (1-2). Like Ripley, Norton believes that man's labor cannot participate in God's art unless he is virtuous.

But god hath made pat of his blessid arte $\mathrm{Al}$ pat be fals shal haue therof no parte. He must haue grace pat wold for pis arte sewe, Therfore of right hym nedith to be trewe. (Proh., 117-120)

Norton then proceeds to humanity in its fallen state: he denounces falsehood, deception, falling for deception, and immersion in worldly pursuits. He warns against "fals Illusions/ which multipliers worch with theyre conclusyons" (11-12). He denounces the covetous

${ }^{205}$ Ibid. 
pursuit of alchemy for the sake of worldly goods and power, a pursuit that has become widespread, and present among "euery state which is within mankynde" (17). In his denunciation, however, he inserts an ambiguity which gives some leeway for empathy. He refers to the Boethian premise, explaining that this is so because "euery estate desirith after goode" (26). The "good" as a philosophical term, refers to the ultimate good, namely God, in Whom, Lady Philosophy tells Boethius, resides the Good, the satisfaction and self-sufficiency that everyone desires. Book III of Boece argues that underneath all the various things men desire is their deeper desire for the good that will make them selfsufficient, and that nothing can provide this end except the Good which is one, and in which all good is united. For example:

"Certes ther nys noon other thyng that mai so wel performe blisfulnesse, as an estat plentevous of alle godes, that ne hath nede of noon other thyng, but that it is suffisant of hymself unto himself ... wel neyghe al the entencioun of mortel folk [travayleth] for to geten it ...." (III, p. 2.90-94; 99-100).

The goods of this world "ben divers that on fro that othir," each of them only partial. They can only be "verraye good," i.e. the 'true' or 'veritable' good, whan thei ben gadred togidre [als] into o forme and into oon werkynge, so that thilke thing that is suffisaunce" (III, p.11.16-30). In addition to its suggestion of the Boethian ultimate Good, however, "good" in Norton's statement "euery estate desirith after goode," ironically alludes at the same time to "goods," since the reader has just been told that these people are covetously seeking material goods. This ironical allusion to the distinction between the ultimate "good," and "goods" renders the term "good" a pungent reminder of the unresolved distance between the material goods or alchemical 'gold' that fallen humanity covets and the spiritual good or 'gold' that they truly desire in the depths of their intentionality. Through its rich workings, the irony also makes a figural connection between the partial 
goods and the ultimate one. It is like relating the human word to the divine word. Such a figural connection is reminiscent of the connection in St. Augustine between the human inscriptions on the inside of the "scroll" stretched across the firmament, and God's Scripture on the other side. ${ }^{206}$ If Christ is the mediator, like a physical scroll on which both sides, God and man, write their inscriptions, then if the human seeker raises his "entencioun" towards Christ, the material goods will become figures of the divine Good. Through the Incarnation's presence in the material world, the sensible figures of men's earthly heaven become shadows or veils of the ultimate Good. Norton's emphasis on the pursuit of the Stone in "euery state which is within mankynde" (17) has the effect of including into the quest the whole range of partial goods that men may desire, and practical purposes into which they translate these desires, as they seek, fall, meet their limits, find Christ in these limits, re-interpret, and continue their journey towards the ultimate "good" that they most truly desire. Art, like Christ, is a mediator. It mediates between the partial goods men pursue to satisfy their longing, and the ultimate good which they truly seek.

The long list of professions and ranks with which Norton represents "euery state which is within mankynde" in lines $17-43$, he clearly groups into representatives of spiritual life, political life, social life, and, finally, the life of labor and production, with focus on "artificers" (39), probably as representatives of all human labor and production. Norton begins with a remarkably long list of men of the church, thus emphasizing the point that corruption is everywhere, and that the men of the Church, who are representatives of the ultimate Good, and who should be, like Augustine's holy men, interpreting this highest Good to men, are themselves corrupt, and their vision limited to

\footnotetext{
${ }^{206}$ See the discussion of the metaphor of the scroll in Chapter Two.
} 
the partial and material goods. His long enjambment of the list of those pursuing the "Philosopher's Stone" suggests the theme of deferral, as it continues breathlessly to an end that keeps deferring: "popis with cardynales of dignitee, / Archbissopis \& bissoppis of hye degree,/ with abbottis \& priours of religion,/ with freris, heremites \& prestis many on" (21 - 24). He then moves on to men of political rank, "And kingis, with princis" (25), and follows them with those of high social rank-, "lordis grete of blode" (25), and the social climbers of acquired wealth and status, "merchantis"(26). Then he moves on to his list of craftsmen and artificers, exclaiming that the "comon workmen" similarly "wil not be owt lafte,/ For as wel as lordis pei loue pis noble craft" (29-30). His list of artificers, which includes both the deceived and the deceivers, contains "goldsmythis" "wevers" "Fremasons \& tanners with pore parish clerkis," "Staynours \& glasiers" and "sely tynkers" and glass tincturers (38-31).

Although, however, Norton seems to be only doing the obvious, satirizing people of all ranks on the basis of their moral corruption, including those who deceive and those who are too much in a hurry to give credence and be deceived, a closer look at his language reveals another and deeper theme underlying the obvious surface voice of morality. He is actually pointing out the human condition- the condition of fallenness and consequent deferral. Such an underlying theme explains, more satisfactorily, the great emphasis he is laying on the all-inclusiveness of this state of corruption. The theme of deferral he attaches to that of fallenness echoes the same theme in Chaucer's Canon Yeoman's Tale as discussed in the Introductory Chapter above. Ignorance and the limitation to sensible knowledge are indeed what Norton associates with deferral, just as Ripley relegated his false "philosophres" of his "Fifth Gate" to the condition of ignorance and deferral. He also places their desire at the center of the action. What is being 
deferred is their desired goal. He conveys the passion and urgency with which the artificers seek the philosopher's stone. The persistence and indestructibility of their hope and desire through repeated disappointments and deferrals is as striking as it is understandable:

But many artificers haue be ouer swifte

with hasty credence to fume a-wai theire thrifte, And alle be it that losse made them to smerte, yet euer in hope continuede theire herte, Trustyng somtyme to spede right welle. Of many such truli I can telle which in such hope contynued al there lyfe, wherbi thei were pore \& made to vnthryfe. (Proh. 39-46)

Norton presents these men in a trap of their own making, and out of which they are unable as well as unwilling to escape. No matter how hard they try, it makes no difference to their goal, which remains equally beyond their reach. The reverse is also true: no matter how much they lose, how far they are impoverished, and how far they "smerte," their "herte" continues "ever in hope," and they continue "Trustyng somtyme to spede right welle." They think, some time will come when they will be fortunate and will "spede right welle." But time and fortune--which are aspects of the same condition-cannot be trusted.

Norton extends his theme of deferral to that of the meaning that is hidden in the old masters' "bokis" which are "to many men ful derk" (Proh., 62). These masters either sought to deceive or, at least, to protect their secrets "In poyses, parabols, \& in methaphoris alle-so,/ which to scolers causith peyne and wo" (61-63). To this sad state of affairs, Norton proposes his Ordinal of Alchemy as a remedy. He explains that since he sees "men made fals which bifore-tyme were true," he is "constrayne[d]" out of "pitee" to "shew the trouth in few wordis \& playne,/ So that ye may fro fals doctryne flee" (9597). 
In many wayis he may not loke,

But only pursue the ordire of this boke,

Namyd of Alchymye the ordinalle,

The crede michi, the standarde perpetuall;

For like as the Ordinalle to prestis settith owte

The seruyce of the dayes as pei go abowte,

So of al the bokis vnorderide in Alchymye

Theffectis be here set owte ordirlye.

Therfore this boke to an Alchymystre wise

Is a boke of incomperable price,

whose trowth shal nevir be defilede,

Thofe it appere in homly wise compiled. [Prohemium, 125-136]

"Of incomperable price" (134) echoes the description of the Philosopher's Stone. But it is a Philosopher Stone specifically due to the divine truth and act of creation it embodies. Norton calls his Ordinal the "crede michi," or "believe me" (128). Like Ripley, he is going to enclose within it truth that is beyond human words. Lines 134-36 emphasize the "trowth" of his "boke," "[t]hofe it appere in homly wise compiled." Through his reference to its homely language in line 136 , Norton warns the reader not to let his mind's eye stop at what the book's vernacular appears to say, since even in its homeliness it is hiding a deeper "trowth." After he states briefly the topic of each of his seven chapters (137-64), and asks for God's guidance and for his readers to pray for his soul when he's dead (165-68), he ends his "Prohemium" with another emphasis on the idea that the sacred truth of his book is encoded within its language, however homely: $\mathrm{He}$ emphasizes the conscious and careful craft with which he has encoded the truth into his book by making a request that "no man for better ne for wors" change a single "sillable" of his "writing": As he proceeds now "to my maters" (166) in the rest of the book, he prays that all men "have my soule in mynd" in their prayers,

And that no man for better ne for wors

Change my writyng, for drede of goddis curs;

For where quyck sentence shal seme not to be, pere may wise men fynd selcouth priuyte;

And changing of som oone sillable 
May make this boke vnprofitable.

Therfore trust not to oon reding or tweyne,

But xx. tymes it wolde be ouer-sayne;

For it conteynyth ful ponderose sentence,

$\mathrm{Al}$ be it that it fawte [lack] forme of eloquence. (Proh., 169-80)

Wherever the reader finds that the language does not yield "quyck sentence," there he will find the meaning in its "selcouth priuyte"- its "hidden and wondrous privacy" (173). Not only should the reader treat every "oon sillable" as crucial for the meaning, but, in order to grasp this meaning he should read the book not "oon reding or tweyne" but "xx." times over again. He also implies the extent to which his text is interwoven with the texts of the past by also telling the reader that to get the full meaning, he has to also "rede many bokis," and place Norton's book in view of their language and context. So, like Ripley and the alchemical masters of the past, Norton promises "To shew the trouth in few wordis \& playne" (96), and disclose the wisdom in the old fathers' books, since the old fathers themselves "made theire bokis to many men ful derk," (62). Yet, like them as well, he encodes the meaning beneath the surface. In fact the very first 2 lines with which he opens his opus, namely the first two lines of the "Preface" which precedes his "Prohemium," he warns:

Liber iste clericis monstrat scientiam, Liber sed laicis auget insciciam; .... (Pref., 1-2)

"THIS Book shews to the initiated knowledge, but intensifies the ignorance of the vulgar",207'

The surface of the text is sufficiently smooth as to provide an uninterrupted flow of seeming sense to the eyes of those "botirflyes" who "wandir \& passe" (2719). His book will thus yield its hidden wisdom only to the initiated, thus making the wise wiser, while

207 Arthur Edward Waite, tr. and ed., The Hermetic Museum restored and enlarged, Vol. II (London: James Elliott and Co., 1893), pp. 3-4. All subsequent modern English words and sentences connected with Norton's Latin "Preface" and placed in quotation marks are from Waite's translation, unless mentioned otherwise. 
it makes the ignorant more ignorant. However, although the homely vernacular gives that smooth and flowing surface along which the readers can glide with nothing gained, it is nevertheless that same vernacular which Norton defends, and to which he gives extraordinary power. It is that same vernacular which will carry in its depths the sacred truth which his Ordinal will impart to the wise. Therefore, “Thogh that I write in playn \& homely wise, / No good man shulde suche writyng despyce" (59-60).

Norton's rerference, in line 173 of the above quoted passage, to the "priuyte" of that sacred truth, is one of the instances where his language echoes Chaucer's language in the Canon Yeoman's Tale as discussed in the introductory chapter above. Norton is telling his reader, as well as any scribe or publisher, that the places in the text where the language seems problematic must not be changed, since this problematic or esoteric language would be a call for interpretation, and it is there that the reader will find the hidden kernel and the secret alchemical knowledge: "For where quyck sentence shal seme not to be, / pere may wise men fynd selcouth priuyte" (172-73). As in Chaucer's Canon Yeoman's Tale, Norton uses the word "priuyte" for the root of the alchemical operation, and the divine knowledge that is hidden in the prima materia of nature, and that he has hidden in his text. He also identifies this "priuyte" with the Incarnate Christ.

Norton, like Chaucer, identifies the shapelessness of language and narrative time in its raw condition as mere sequence, with the deferral of the Stone in the alchemical operation. He also identifies the true alchemical operation with the operation through which language receives sacred truth, and allows this truth to act as a formal principle which shapes the process by which it—language — unfolds both to grasp and disclose that same hidden truth. Norton, also like Chaucer, seeks to enclose divine Wisdom within 
England's homely vernacular. He seeks to heal not only the language, but also the whole nation.

Central to the project of concordance which Norton's "Ordinal" comprises, is England and the English Language. He sought to align the alchemical operation with the Christian liturgy and the cyclical operations of Nature. He also sought-I argue belowto align the Classical literature and philosophy, in which alchemy is rooted, with Christian doctrine, and to show that all those center round the same ineffable kernel, and unfold their operations in accordance with the same form. The idea of the "golden mean" which was central to Ancient Greek philosophy in general, becomes in Norton the shape of the rational intellect as it imitates the sacred form of the liturgy as well as the alchemical and cosmic operations of Nature. Norton sought to accomplish all these concordances through the humble medium of the English Language. The reverse is also true, he sought to incorporate the Incarnation--or, more precisely, that ineffable yet incarnate entity, God's Wisdom and Word, which makes possible all those transformative operations his Ordinal is aligning together--as a formal principle that shapes the language's temporal unfolding of its meaning. By triggering language to perform the transformative liturgical and alchemical operation, he sought to connect it to that kernel of divine truth which is hidden in its "selcouth priuyte" (173) and which is the center, source and shaping principle of all these operations. In doing so Norton's Ordinal will be an agent of divine Grace, calling upon divine Wisdom to be incarnate in the English language, thus empowering and transforming it into a dynamic whole and a plenitude that is inseparably bonded with truth at a most radical level. In the following discussion, Norton advises the King of England to die to the world by turning his back on it, holding onto the Cross, and lifting his intentionality to God in prayer. In doing so, he will usher a 
golden age for England. As identified with the King, Norton intends for the English language of his Ordinal to be doing the same, and to make its figures a mediating boundary for bringing divine truth to human words.

Norton's claim of the function of an "ordinal" for his book, essentially indicates that he conceives of his book as shaped by divine inspiration. An "ordinal" makes a unity of the "werke" with the cosmic cycles of nature and with sacred history, into both of which God's Word is incarnate. He gives his opus the status of the sacred by identifying its temporal and linguistic unfolding with the liturgy. Through his reference to "O Sapientia," he particularly emphasizes the advent evening masses which anticipate the new day of the coming of Christ into the world.

In his "Preface" Norton directly claims his book to be a "don[um] dei":

5 Liber fiducie est et veritatis,

6 Regibus consilium, doctrina prelatis;

7 Et liber vtilis viris beatis

8 Viuere qui cupiunt absque peccatis.

9 Liber secretus, liber doni dei, 10 Electis semita viris boni spei, 11 Valens constantibus firme fidei. 12 Ve non credentibus verbis oris mei! (Preface, 5-12)

"[5] It is the book of confidence and truth, [6] full of counsel for kings and of teaching for prelates, [7] a book useful for sainted men, [8] who wish to live unspotted of sin; [9] a secret book, the Book of the Gift of God, [10] to chosen men a pathway of true hope [the book as pathway to divine knowledge], [11] a strength to those constant in firm faith, [12] and who unwaveringly believe in my words." 208

Norton is even identifying his book with sacred scipture. Those who steadfastly believe in it—in "verbis oris mei" (12)—will find "the pathway of true hope" (10). This same calling of the reader's attention to "verbis oris mei" he repeats again towards the end of the "Prohemium" in the words "crede michi", or "believe me" which he offers as another

${ }^{208}$ The line numbering is my own. 
title to his Ordinal in the passage, quoted above, where he explains the meaning of "ordinal." He claims it to be useful even to the "viris beatis" (7), those who are already saintly, and to give strength to men of faith (11). He even takes a prophetic stance towards the kings of England. He claims that glory for England was being deferred due to these kings' lack of trust in God (29-30). God gives freely of His fountain of love (24), but it only reaches the virtuous, just and faithful, those "Qui diligunt iusticiam mente cum beata" (26), since people's sins retard (tardantur) His gifts from reaching them. In contrast to this deferral Norton prophesies a golden age for England (39). A king ${ }^{\mathbf{2 0 9}}$ will come "who shall have obtained his honours by means of this Art," and by implication by means of his Ordinal. Through learning from "this Art," this King will "mend his old manners" and "reform the kingdom" (31-33). This prophesy he repeats in his Chapter V (1414-32). Both prophetic passages, of the "Preface" and of the fifth chapter, contain the theme of deferral, and present the coming of that savior-king as an end to this deferral. Both also present the end of this deferral as a grace, descending directly from God:

The olde man seide when men shalle se The holy crosse honouryde both day \& nyght In the londe of god in the lond of lyght; which may be do in welle good seson, But longe delayed it is withowte resone; when that bigynnyth note wel this thinge, This science shal draw towa[r]de the kynge; And many mo gracis ye may be bolde, Mo then of vs shulde now be tolde. Grace on that king shalle descende when he olde maners shalle amende; (V, 1418-28)

"Longe delayed it is withowte resone" (1423). But there will be a "bigynn[yng]" (1424). At the center of the golden age which "this science" will trigger by causing the king's

\footnotetext{
${ }^{209}$ For Norton and Ripley's relation to King Edward IV before and after his accession to the throne, see Jonathan Hughes, "Politics and the Occult at the Court of Edward IV." Princes and princely culture, 14501650 .
} 
reform, Norton places the symbol of the passion, death and resurrection of Christ: The mark of the renewed England is that in it "The holy crosse" will be "honouryde both day and nyght" (1419). The redeemed and golden-age England will be an alchemical product, a microcosm and a Philosopher's stone, formed and centered round the cross, the point at which time meets eternity, and the natural mode of knowledge and being passes into the divine.

There is another point which deserves attention in Norton's prophetic language, though it may not at first sight appear to be deliberate: There is, implied in this prophesied redemption, a meeting of the beginning with the end and an association of the beginning of a new life with the event of death. By emphasizing the centrality of the cross to redeemed England, in the fifth chapter, Norton effectively associates the attainment of a new and redeemed life with the experience of death. The cross marks Christ's death, and the end of his life on Earth. At the same time, however, this same event of death is the beginning of the resurrected Christ Who now carries His humanity, including the physical human body, with Him into heaven. Christ, through the Incarnation, has become fully human as well as fully divine. His passage through death and His harrowing of the state of infinite difference from self, deferral and privation that is Hell, into the divine mode of knowledge and life, rebounds back onto Earth. The bridge he built between time and eternity also provides a stable starting point for the unfolding of human life on Earth as well as for the unfolding and building of the human body politic. The King and the body politic are one. This redeemed king, now become saviorking, will be a figure, in time, of Christ the King in eternity. Since God's eternal Presence is itself Heaven, the King who is in contact with it, will be the agent through which Heaven will spread its order and harmony on earth. 
The theme of joining life's beginning to its end and life's end to its beginning again, is similarly present in the context of the prophesy with which Norton ends his Latin "Preface," although more 'selchouth[ly]' so. In the last four lines of the "Preface," Norton turns from speaking about the King as a third person to addressing him directly in the words "O King." In the lines in which he urges the King to pray, Norton makes two layers of figural identification: he identifies the King's redeemed mind with both with "God the King," and with redeemed England in its golden age. Immediately after his mention of the golden age, Norton adds a line in reference to that golden age, which Waite translates as: "which [i.e., the golden age] shall not then be hoped for as future," or, in other words, which shall not continue to be deferred. Indeed deferral is centrally relevant to the context, but the text of this line is more complex than Waite's translation suggests, and includes additional meanings. That last line is in fact a quotation from Horace's fourth epistle entitled "to Albius Tibullus." The context which this allusion adds is quite significant. Norton's address to the King runs as follows:

O rex hec facturus! deum regem ora, Et eius auxilium pro re hac implora. Tunc regi iusto fulgenti mente decora, Grata superuenient qua non sperabitur hora. (Pref., 37-40)

"[37] O King, who art to accomplish all this, pray to God the King, [38] and implore His aid in the matter! [39] So the glory of thy mind will be crowned with the glory of a golden age , [40] which shall not then be hoped for as future.",210

With these lines Norton gives a picture of the King being an agent of Grace, a figure of Christ, situated like Him in the middle, as a link between God and England. He is a microcosm of England, as England of the Cosmos, and instead of being focused on the world, as he had been, he is now turned towards God, in a suppliant and receiving

\footnotetext{
${ }^{210}$ Waite, p. 4. The line numbers are my own addition.
} 
attitude. The last line in its Horatian context gives the effect of a healing release from oppressive subjection to the condition of deferral. But also more than that, it does so in an unexpected way, through a sort of peripeteia. Without recognizing the source, and without familiarity with it, Norton's readers would have missed the fact that Norton is quoting a line which in fact refers to death and to the necessity of incorporating the inescapable event of death into one's intellectual attitude. He is advising the King to obtain a healthy and joyful attitude towards life by facing death and incorporating the knowledge of his own — and by implication the body-politic's — natural life's finitude into his mind and being:

Inter spem curamque, timores inter et iras omnem crede diem tibi diluxisse supremum: grata superveniet quae non sperabitur hora. (Horace, Epistles I, vi. 12-14) ${ }^{\mathbf{2 1 1}}$

In the midst of hope and care, in the midst of fears and passions, believe each day that dawns on you is your last; more gratefully will you greet the hour that is not expected. ${ }^{\mathbf{2 1 2}}$

Smith Palmer Bovie gives the meaning of "diluxisse" and its context in line 13 as: "the light of morning breaks through (dilucet) the darkness of night." 213 Through one's 'death' a new beginning will arise that is present and without deferral. Each day will break out of darkness, not as a habitually expected continuum, but as a gift beyond one's expectations. By association with Horace's context, Norton is advising the King, and by implication the initiate reader, that to obtain effective healing one must face death as though one were coming to the end of one's life now. One must incorporate the

\footnotetext{
${ }^{211}$ Horace, Horace's Complete Works (London : Dent, New York, Dutton, 1911, rpt 1953). http://www.gutenberg.org/files/14020/14020-h/14020h.htm\#THE_FIRST_BOOK_OF_THE_EPISTLES_OF_HORACE .]

${ }^{212}$ Tomislav Kuzmic, ed., Eudict: European Dictionary (EUdict.com, 2013), Web, Accessed Nov. 30th, 2013.

${ }^{213}$ Smith Palmer Bovie, Satires and epistles of Horace: a modern English verse translation (Chicago: University of Chicago Press, 2002), p. 257.
} 
knowledge of one's finitude into one's mind and being. Norton is in fact identifying the King's turning his face in the direction of God instead of the world, with the experience of death to self and to world- the experience of the end of one's natural and temporal life. His acceptance of the 'now' reality of this finitude will turn the King's life from a state of endless deferral of satisfaction to a state of existence at the constant meeting point between time and eternity, earth and heaven. Each new break of day out of darkness will be a undeferred gift and a true joy.

Norton, however, is doing more even than this. He is aligning Classical and pagan Horace's ideas with Christian ideas: he is aligning Horace's idea of existence at the point where death meets new life and the end-limit turns into a new beginning, with the Christian idea of passage with the crucified Christ from time into eternity. The alignment works in both directions: the resurrection in heaven becomes also the break of a new day on earth, and the individual's rebirth back on earth at every moment of his life. When the Christian King turns to God at the expense of dying to self and to world, he performs two different parts of a single and circular action: The King will come to exist simultaneously on more than one level and in more than one mode of being. He will have passed through the "holy crosse" which will be "honouryde both day \& nyght," into heaven, and at the same time his new union with Christ will rebound back onto his life on earth and transform it into a golden age: presence and plenitude no longer deferred. The break of a new day out of darkness will occur both in terms of a resurrection after death, in heaven, and in terms of a new and golden age on earth. This new life on earth is bound into form and being precisely through its finitude. This finitude, however, is a gift of Grace that has resulted from its incorporation of Christ into itself, and has become free from the tyranny of absolute time, and from the oppression of relativity and deferral. 
However, while Norton is interested in aligning his Classical heritage with the Christian one, there is an important difference to keep in mind between the way in which Horace's friend would accept death and the way Norton is calling on the King to do so. Norton is calling on the King to turn to God beyond the limits not only of one's physical being but also beyond the limits of one's own mind, and to be in a relationship with this ineffable source of Being. It is not by focusing on death or 'knowing' it, that the King will experience and come to accept his death, since non-being is unknowable in itself. Rather, it is by focusing on Being and ultimate, though ineffable truth, that he will experience the limits of his natural life. By contemplating and desiring divine Being beyond his earthly life, the King will "die" and pass into that higher mode of being. It is in the act of seeking and contemplating God beyond his own natural limits that the King will be transformed, and come to have being, like the Philosopher's Stone, both in eternity and in time simultaneously.

There is also another important difference between Norton's and Horace's advice: Horace's friend must obtain the new wisdom by his own powers, whereas Norton's King can only do that when he prayerfully adopts an attitude of receiving from an immeasurably greater Being than himself. Norton's King will receive his ability to pass through death, and his knowledge of divine being from God, and not through the power of his own mind. It is in the similarities, however, that Norton is interested, rather than the differences between the Christian and the Classical paths to Wisdom. Like Ripley, and like Arnaldus of Villanova, Norton aligns the redeemed King, reader or Philosopher's Stone with the resurrected Christ. As in Ripley's Compound, so in Norton's Ordinal, Christ is the agent and mediator through whom the Philosopher's Stone passes through death and is reborn perfect and whole. But while Ripley uses 
mythical language, associating Christ with Mercury, and both with the golden mean, Norton uses more literal language and presents the mechanics of alchemical transmutation in more directly philosophical terms. abstract, mechanics of the golden mean, without using Arnaldus or Ripley's more mythical language. Norton, however, depends more on the textual allusions which he interweaves into his own text. In the epistle to which Norton alludes in the last line of his "Preface" discussed above, Horace reminds Albius of the gifts he is enjoying through language that points to a balance between opposites, thus encoding within it references to the golden mean. In general, he is telling Albius that "You are a happy man with all the gifts outward and inward.",214 "Non tu corpus eras sine pectore. Di tibi formam" ("You were not a body without a mind. The gods have given you a beautiful form" ${ }^{\text {215 }}$ ) he tells Albius. Albius' beautiful "formam" comes from the combination of body and mind. Even the word "pectore" which Marsahll translates as "mind", is also "“cor,"” and "“animus." It is thus a combination of mind and heart. What more can anyone want, he conveys to Albius, than the "mundus victis non deficiente crumena" that he enjoys. "Mundus victus" is "the comforts of life; a happy mean between sordidus and luxuriosus, opposed to immunda pauperies, Ep. 2. 2. 199."216

Norton's interest in a concordance between the form of the Christian pathway to redemption and wisdom, and that of the Pre-Socratic and Classical pathway to the golden mean, is clearest in his fifth and sixth chapters. So is his interest in aligning these with the cosmic cycles of nature. But just as is evident in the difference between the ways in

\footnotetext{
${ }^{214}$ Edward Charles Wickham, ed., Quinti Horatii Flacci opera omnia: The satires, epistles and De arte poetica ..., Vol. II (Oxford: Clarendon Press, 1891), p. 235.

215 John Marshall, ed., Horace's Complete Works (London: Dent, New York, Dutton, 1911, rpt 1953), 221 22.

${ }^{216}$ Horace and Smith Palmer Bovie, Satires and epistles of Horace : a modern English verse translation, 257.
} 
which Norton's King and Horace's friend will 'know' death, Norton is aware of deep differences that must be overcome, between the two pathways to wisdom. Horace does not ask his friend to look beyond the limits of his own mind, in order to accept death and allow each new break of day to consequently become a full presence and a joy. Norton's King, in contrast, will seek God beyond the limits of his mind. He will know death and face his mortality by having God, not death, as his object of knowledge, and he will attain this knowledge and wisdom through Grace and the infinite power of the divine Intellect, and not merely through the powers of his own natural reason. But at the same time, Norton obviously believes that these differences can be overcome, or at least, that the one can be framed within the other.

The Ordinal is therefore a far more ambitious project than its vernacular simplicity seems to suggest at first. Norton's clandestine quote from Horace is one small instance of how consequential his allusions can be, whether they are verbally made quotes and allusions to texts and authors, or theoretical structures indirectly built into the language. The artistic and poetic implications of natural philosophy in general, and alchemical theory in particular, have not yet been sufficiently elucidated, and as a consequence there may be a wealth of meaning and structure in medieval literature to which we remain blind, and much work needs to be done in that direction.

\section{"Alteration," "Generation," "Creation"}

Norton's ambitious project, in the Ordinal, is to join the operation of alchemical transformation to the divine Act responsible for the genesis of the universe, for all its natural operations and for all the processes shaping human and cosmic existence. But this necessarily called for reconciliation of the natural philosophy underlying alchemy with Christian doctrine and its understanding of creation. The Ordinal shows that Norton, 
highly-educated and philosophically astute, was aware of the radical differences between the alchemical trajectory of cosmic "generation," based on Ancient Greek natural philosophy, and the Christian account of "creation." The former began and ended in the prima materia, or arche, the Green Dragon itself transformed into a microcosm, and the latter began and ended in a personal God's "Word" or "Wisdom," ontologically prior to the prima materia and posterior to the created world. The cosmos in the former had its beginning and end within itself and its own nature, while the latter bound the cosmos into form by a beginning and end ontologically prior and posterior to its own being, and by an Act immeasurably greater than itself. Norton worked to include the narrower trajectory of the Green Dragon, from prima materia (its own) to cosmos, within the ontological boundaries prescribed by God's personal Act of Creation, creating it from beyond itself, and binding it into indestructible form, within boundaries that no infinity of primal chaos, or time and space, can remove. That infinity itself is tightly bound within these bounds.

The most important characteristic that Norton considered crucial to the success of the Philosopher's Stone-in both its pagan cycle that begins and ends in the Magnesia of the prima materia, and the Christian one that begins and ends in the "leap" of Wisdomwas its inclusiveness. It absolutely had to include the entire ontological structure of the universe. At the same time, this "whole" must be dynamic. It must incorporate the entire operation of transformation within its being. Aristotle's books are replete with criticism of the Pre-Socratics - and even of Plato-especially for their rejection of change, and especially change in the sense of a new thing or event coming into being. He criticized them for rejecting the possibility of anything new coming into being in their philosophies, and for for limiting of "change" or transformation to mere "alteration," and arguing that nothing can come into being that is not already there, already a part of Being: 
we must first consider whether there is anything which comes-to-be and passes-away in the unqualified sense: or whether nothing comes-to-be in this strict sense, but everything always comes-to-be something and out of something-I mean, e.g. comes-to-be-healthy out of being-ill and ill out of being-healthy, comes-to-be-small out of being big and big out of beingsmall, and so on in every other instance. (On Generation and Corruption, I.3)

Aristotle is arguing that we cannot account for the existence of the universe within these narrow limits in which the old philosophers have confined change. "Com[ing]-to-be something ... out of something," such as someone's coming to be ill out of being healthy, or vise-versa, is not coming-to-be in the "strict sense." It is not "unqualified." It is merely "alteration." The body is a constant "substratum" in the change. It is altering from being ill into being healthy, or vise-versa:

we must distinguish (a) the substratum, and (b) the property whose nature it is to be predicated of the substratum; and since change of each of these occurs; there is 'alteration' when the substratum is perceptible and persists. (On Generation and Corruption, I.4)

Such change, which Aristotle describes as mere alteration, is not inclusive of the action that brings the Cosmos — and as such the microcosmic Philosopher's Stone-into being. Philosophers must take into consideration what happens when there is no substratum to link one state of the 'change' to the other. Aristotle now reaches down into the deeper origins of things. What happens when the substratum itself becomes something else, such as when a seed becomes a tree? In his examples, Aristotle returns to the deep and universal origins of nature, viz. the four elements underlying all things: What happens when one element such as air changes into water? This is much more radical than "alteration":

But when nothing perceptible persists in its identity as a substratum, and the thing changes as a whole (when e.g. the seed as a whole is converted into blood, or water into air, or air as a whole into water), such an occurrence is no longer 'alteration'. It is a coming-to-be of one substance 
and a passing-away of the other-especially if the change proceeds from an imperceptible something to something perceptible. (On Gen.I.4)

Yet, "a single matter must always be assumed as underlying the contrary 'poles' of any change" (On Gen. I.4) So what is the single matter underlying events of things coming into being that were not there, or did not necessarily have to come into being. After all, a seed does not necessarily have to germinate and grow, or be placed under conditions that will give it a chance to do so. For Aristotle these events of "coming-to-be" and "passingaway" are most fundamentally the actions of an agent and a will. For him, it is action that is the ultimate substratum of existence. The "generation" of something, in the sense of its "coming-to-be" unqualifiably, or non-derivatively, is brought about by an actant or "agent." The ultimate actant is God, who is Pure Act. Aristotle turns around the PreSocratic trajectory — of a beginning and end in a materially conceived "One" as prima materia - into the trajectory of an action that moves from potentiality to act, and that is, paradoxically, itself the substance of the actant who performs it. As opposed to the PreSocratic scheme, the Aristotelian emphasizes that new things can come into existence, and that the prima materia is merely a state of potentiality - the very possibility of the action - which if thought of spatially, has no actuality, and is no more than a void. The Aristotelian trajectory also began in the act of a Prime Mover who is prior to this potentiality. The Pre-Socratic trajectory of cosmic generation contained all Being within the prima materia. It reduced the action that produced the cosmos to no more than "differentiation" out of this prima materia. Although the Pre-Socratics presumed a cosmos formed out of the unity of opposites that produces the golden mean, Aristotle argued that their trajectories were no more than a process of differentiation from the prima materia, and a return to it by "dissociation." Aristotle took the beginning of the 
trajectory of the generation of the cosmos to a radically deeper and more primary "First Cause," namely the "Prime Mover," who is God, and who is not the prima materia. In this sense he came close to the Christian God Who creates out of nothing. But Aristotle left loose ends behind, and a contradiction in his philosophy: He allowed the prima materia, or primal chaos, which he had defined as "potentiality," to co-extensive with God, or at least to seemingly do so. It remained for Augustine first, and then Aquinas, to correct him. Nevertheless, before proceeding to Aquinas' definition of "creation," it should be emphasized that Aristotle's system was not mechanical as is sometimes claimed. Even though his system needed some corrections, he aimed for freedom. This has most important implications for his concept of artistic creation:

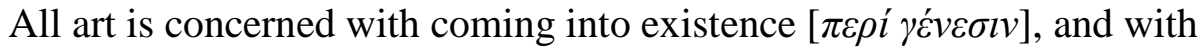

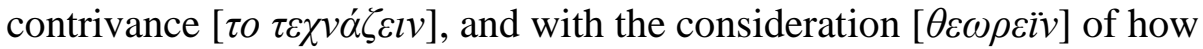
something (which is capable of existing or not existing, and the cause of whose existence is in the maker and not in the thing made), may come into existence. For art is not concerned with things that exist of necessity or come into existence of necessity, nor yet with things that come into existence by nature: for these latter contain the cause of their existence in themselves....

Art, then, as has been said, is a truth-attaining intellectual quality,

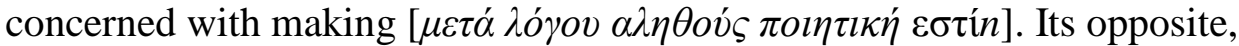
want of art, is an intellectual quality, concerned with making, that fails to

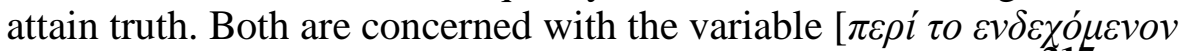
$\dot{\alpha} \lambda \lambda \omega \varsigma \dot{\varepsilon} \chi \varepsilon l v]$. (Aristotle, Nichomachean Ethics, VI, 4.11-24) ${ }^{\mathbf{2 1 7}}$

Art, in other words, is action. It is free-willed and non-derivative.

As Aristotle criticized his predecessors for the narrow limits they placed on the trajectory of change, and he widened and deepened it from "alteration" to "generation,"

${ }^{217}$ Aristotle and L. H. G. Greenwood, Aristotle Nichomachean ethics. Book six, with essays, notes, and translation, by L. H. G. Greenwood, ed. and tr. Leonard Hugh Graham Greenwood (Cambridge:

Cambridge, University press, 1909), p. 97. The insertions of Greek equivalents is mine, derived from the parallel Greek text on p. 96. C Center for Research Libraries

http://dds.crl.edu.proxy.its.virginia.edu/CRLdelivery.asp?tid=4802

http://catalog.crl.edu.proxy.its.virginia.edu/search/a?searchtype=o\&searcharg=635555642 
so, in turn, Aquinas, in his comments on Aristotle and individual Pre-Socratics, criticized the narrowness of Aristotle's account of "generation" which began only from "potentiality," to "creation," since he left it, or seems to have left it, as something independent of God, which God then moves, brings to actuality and binds into form. Augustine and Aquinas included "potentiality" in creation. Potentiality, the very possibility of existence and action, is created by God. The cosmos 'began' from nothing except the act of God:

On the contrary, On the text of Gn. 1, 'In the beginning God created,' etc., the gloss has, 'To create is to make something from nothing.'

I answer that, As said above ([375]Q[44], A[2]), we must consider not only the emanation of a particular being from a particular agent, but also the emanation of all being from the universal cause, which is God; and this emanation we designate by the name of creation.... Therefore as the generation of a man is from the "not-being" which is "not-man," so creation, which is the emanation of all being, is from the "not-being" which is "nothing." (ST I, Q45.a1)

By "the generation of a man is from the "not-being" which is "not-man," Aquinas is referring to the material and natural process. "Creation" is not a natural process, since it precedes nature, and even the potentiality of nature. Aquinas also addresses the spatiality in which thinkers habitually conceive of the "nothing" in the statement that God created out of nothing. He draws a distinction between the idea that a vacuum precedes the world and the idea that nothing precedes the Creation. The idea of a vacuum, and the debate on whether or not a vacuum was possible in nature, were part of philosophical discourse since the Pre-Socratic concept of the primordial arche as an "apeiron" ("the unbounded"), as opposed to "peiron," "the bounded"), and their debate on how motion was possible. Those Pre-Socratics who tended to be more Pythagorean, allowed there to be an infinite apeiron (Norton's latin "vасиио" (V. 1686), and for the cosmos, and 
musical harmony itself, to be constituted out of an interplay between that apeiron and the peiron (Norton's latin "pleno"). Those who claimed that a vacuum was impossible in nature, as most of the Milesian and Eleatic philosophers, had then to find ways to account for motion in space. This debate was still alive during the Middle Ages. The impossibility of a vacuum was one of the principles some medieval authors used in their argument that the world was beginningless. Aquinas describes their argument in the following “objection":

Objection 4: Further, a vacuum is where there is not a body, but there might be. But if the world began to exist, there was first no body where the body of the world now is; and yet it could be there, otherwise it would not be there now. Therefore before the world there was a vacuum; which is impossible

Reply to Objection 4: The notion of a vacuum is not only "in which is nothing," but also implies a space capable of holding a body and in which there is not a body, as appears from Aristotle (Phys. iv, text 60). Whereas we hold that there was no place or space before the world was. (ST I, Q46.A1) 218

"Nothing" is unknowable since it has nothing to know. But unlike what Parmenides had held, which is that it is impossible to make any statements of truth about it, Aquinas held that we can still know privation in the sense that we know it for what it is; and we know it for what it is by analogy with Being. A void is the image the mind projects of non-being in order to refer to it. Since space consists of thought-as Augustine argues in Confessions, books $10 \& 12$ - and since the mind thinks spatially, it perceives Being spatially. By analogy with its mental representation of Being, it perceives the absence of Being as empty space. But in view of the understanding that Being is Act, the mind can then proceed to inform itself that Being is not spatial. The idea that the event occurs out

\footnotetext{
${ }^{218}$ All quotations in English translation from Aquinas' Summa Theologia (-ica) are from Saint Thomas Aquinas (1225?-1274), Summa Theologica: First Complete American Edition in three Volumes, tr. Fathers of the English Dominican Province (New York: Benziger Bros., Inc., 1947).
} 
of nothing does not mean that it derives from something which is a "nothing," but means that God's creative act is absolutely non-derivative.

For Aquinas, "generation" still derives from potentiality, and is thus not "creation," even though it is "nobler" than "alteration." The range that "generation" covers is wider that that of "alteration": "Alteration" begins with something more "noble" than the location from which "generation" begins, since it begins with things already created in nature, but its end or "whereto" is less noble, since that is merely accidental. Its range is the narrowest. "Generation" begins with potentiality "the privation of substantial form," which is less noble (i.e., less completed) and ends with something noble. This means that "generation" covers a wider range. Alteration begins and ends in the sensible world, while generation begins from a point before the sensible world itself was generated. It therefore covers a wider range of the ontological structure of being than does "alteration." "Creation," however, returns to the least noble "wherefrom" (nonbeing) and ends in the most noble "whereto," thus covering the entire range of being, since it begins before it:

Reply to Objection $2: \ldots$ generation is simply nobler and more excellent than alteration, because the substantial form is nobler than the accidental form; and yet the privation of the substantial form, which is the term "wherefrom" in generation, is more imperfect than the contrary, which is the term "wherefrom" in alteration. Similarly creation is more perfect and excellent than generation and alteration, because the term "whereto" is the whole substance of the thing; whereas what is understood as the term "wherefrom" is simply not-being. [ST I, Q.45.A.1, "Reply to objection 2"]

The "whereto" of "creation" is the "whole substance of the thing," with nothing left outno loose ends. Its "wherefrom" is absolutely nothing: "not-being." Its range, therefore, is ultimate: from complete non-being, to complete being. 
I argue that Norton was aware of these differences and sought to lift alchemical transformation from the sort of beginning which Hermetic literature and alchemical authors gave it in the prima materia, to a beginning in God's act of creation out of nothing. Alchemical literature, such as the Rosarium Philosphorum briefly discussed above, in connection with Ripley, had already identified the fully transmuted "Stone" with Christ, and its rise out of "death" with Christ's Resurrection. But that was a dehistoricized and equivocal identification of the transformed human as Christ himself, omitting the difference between the two.

The implications of a hermeneutic journey that begins from the prima materia instead of from a "leap" event, involve the sort of reversal of the hermeneutic priority which Chiara Chrisciani argues is characteristic of alchemical literature. Chrisciani refers to Arnaldus de Vilanova' statement "Elixir interpretatur Christus," and describes the hermeneutical attitude in the Tractatus Parabolicus attributed to him as one that makes "the sacred text illustrat[e] the alchemical process, and not vice versa." Crisciani argues that the relationships the Tractatus sets up among the three parallels, result in an inversion of the normal direction of the hermeneutical process. "Interpretatur," in Arnaldus' formulaic statement, is ambiguous, since it allows the direction of the interpretation to be switched either way. The Tractatus inverts this order and uses the words of the prophets and the life of Christ which followed, to interpret nature. "The prophets' words come true both in the real history of Christ and in the material process of the elixir, the saviour of matter," and the hermeneutical process of the Tractatus moves towards nature as its end, instead of Christ: "the path of allegorical exegesis has been 
inverted." 219 The present study of Norton's Ordinal in relation to its Ancient Greek philosophical roots, unveils the origin of this inversion in the Ancient concept of the primordial chaos as the "One" out of which all that is emerges and to which it returns. The evidence shows that Norton was aware of this problem, and aimed to Christianize alchemy rather than merely appropriate the language of Christian doctrine to it. But he sought to do that while fully retaining alchemy's Ancient philosophical structure. Whether he was successful in his ambitious project, or to what degree, will be left an open question, for the reader to contemplate.

\section{The Pre-Socratic Trajectory}

Norton was aware of the radical differences involved, and his attempt to overcome them and secure for alchemy a path within Christian doctrine involved fitting the narrower trajectory within the wider one. I first present a sketch of some Pre-Socratic elements that deeply influenced the form of the alchemical operation, after which I discuss the Christian trajectory that Norton implies in his Ordinal, and briefly examine a sketch he himself gives, of the way he fit the one into the other.

Norton revered alchemical natural 'science', “magyke naturall” (V, 1688), as a sacred science, and he based that reverence on the logic of inclusiveness. It is a similar logic to that on which Aristotle based his reverence for "Metaphysics" as a "divine science" (Met., I, 982b.4-983a.9) ${ }^{\mathbf{2 2 0}}$. It is the logic of the ontological inclusiveness of its object of knowledge:

But the chief mastres a-monge sciencis all

219 Chiara Chrisciani, Opus and sermo: The Relationship between Alchemy and Prophecy (12th-14th Centuries), Early Science and Medicine 13 (2008) 4-24, pp. 21; 23-24.

${ }^{220}$ For the English translation I have used Hugh Tredennick, tr., The Metaphysics, Aristotle in 23 Volumes, Vols.17 (Books 1-9), 18 (Books 10-14 (Cambridge, MA: Harvard University Press; London, William Heinemann Ltd. 1933, 1989). 
For helpe of this arte is magyke naturall.

When the iiij elementis wisely ioyned be, And euerych of them sett in his degre, Then of dyuers degrees \& of diuers digestion Colours wil a-ryse towarde perfeccion. (V, 1687-92)

Line 1689 is an implied explanation to the claim the previous two lines make for the superiority of the science of natural magic: "The iiij elementis" are in alchemy the foundations of the structure of the entire universe. Norton is arguing here that in its art, alchemy returns to the first principles of existence, and is consequently able " $\mathrm{Bi}$ oure outward hete artificiall" $(\mathrm{V}, 1698)$ to cause nature herself to perform the artistic labor of generating the Philosopher's Stone as a microcosm, containing absolutely all that constitutes the Cosmos: "Then nature excitid to labour will not cese / Many diuersitees of degrees to encrece" $(\mathrm{V}, 1699-1700)$. Norton repeatedly stresses the "diuersitees of degree" throughout his description of the alchemical work, since the stone must comprehend all that is in the universe, even in all the infinite sets of degrees between its infinite possible pairs of opposites. The science that seeks the most primary causes is superior to all others because its object of knowledge is the most ontologically inclusive. By implication, it is the culmination of the didascalic journey and the science that attains wisdom. Norton places it at the end of his list of sciences, making it higher even than the highest of the quadrivium. The alchemist, through his knowledge of the degrees involved in the constitution of the four elements, their differentiation and relationships with each other, will be able to understand the genesis of the universe, and to repeat the path of this genesis in his own work, thus successfully producing the stone as a complete microcosm.

Aristotle gives a similar inclusiveness to Metaphysics. He explains that its object of knowledge is knowledge itself, in its entirety: "we call this the only independent science, since it alone exists for itself" (Met. I, 982b.27-28) and not for a utilitarian 
purpose that seeks a partial good. It seeks the Good in its entirety (I, 982b.4-7). It is a "divine" science because "God is the sole or chief possessor of this sort of knowledge" which Metaphysics seeks" (Met., I, 983a.9). In seeking God's knowledge man seeks that which is beyond his power: "its acquisition might justly be supposed to be beyond human power" (I, 982b. 28). The causes and principles he seeks are those "whose knowledge is Wisdom" (I, 982a.3). The ontological inclusiveness of the object of this science is therefore complete and liminal. Other sciences study only parts of Being. Metaphysics studies Being as a whole. Aristotle describes the seeker of such knowledge as an artist. Aristotle's claim as such may help explain the fact that the alchemical 'scientist' as well, considers himself a 'philosopher' and an 'artist': The artist, like the Aristotelian metaphysical philosopher, seeks to know not only the parts but the whole. Aristotle argues: "Artists are wiser than men of mere experience," since the latter know only partial causes, or causes of parts of being, but the artist knows first causes. "Artists know the wherefore and the cause." That is, artists know the end ("wherefore") and the beginning (the cause or "wherefrom") (Met., I, 981a.24-981b.20). Since both the beginning through the "Prime Mover" and the end in divine knowledge, or "Wisdom," are "beyond human power," it follows that for Aristotle as well, the operation of knowledge can only be completed when the pilgrim or knowledge seeker "hevy[th] up the heved" and "entencioun" beyond his own mortal limits and the universe's ontological structure. Both the alchemist and the metaphysicist are artists, and both Norton's "magyke naturall" and Aristotle's Metaphysics are divine due to their ontological and epistemological comprehensiveness and to the transcendence of the knowledge they seek, knowledge that is proper to God. For Norton as it was for Ripley to know the secrets of alchemy, is to be in touch with God, their divine source. It is to have arrived at the 
spiritual treasure-house that is Wisdom, at the end of the journey and the top of the ontological and epistemological climb.

Wisdom implied for Norton, as it did for Ripley, the alchemist's contact with God Who, though beyond the limits of the natural cosmos and natural Reason, is their source. Unless the pilgrim cross the boundaries of his natural being, which boundaries consist of his own mortality, he will not reach the eternal fountainhead of creation so as to participate in its creative act, and the fountainhead, as well, of the love which moves human intentionality to seek not only natural goals but also divine. This leap beyond oneself is one of the fundamental principles that "Chaucerian" George Ripley and Thomas Norton share. They both stipulate the imperative that the alchemist possess a 'categorical mind', if he is to succeed in transmuting his stone into a microcosm and Philosopher's Stone. By 'categorical mind' I mean one capable of performing a reduction on the spatio-temporal world and perceiving it as a unity and a whole. A category is by its nature a bounded entity. A mind that perceives a category is a mind that exceeds this category. It perceives it in its entirety and as a whole, and thus also perceives it as bounded, 'formed' and as such, "created." Norton, like Ripley, sharply distinguished between the false philosophers who separated the parts of the stone "manually" and, as such, sensibly, and the alchemist who separated them "philosophically." The philosophers who separated the stone "manually" were those whose art was limited to what both Aristotle and Aquinas called "alteration." I discuss, below, those signs which indicate that Norton wanted to "create" even though he often used the word "generate."

While the roots of Medieval alchemy may be traced to a multiplicity of ancient cultures and religions, its philosophical rather than occult principles are perhaps most 
recognizable in Pre-Socratic philosophy, though that itself, too, must have contained a fusion of elements from a multiplicity of Mediterranean cultures and religions. One of the foundations of Pre-Socratic philosophy is the idea of the natural passibility of the elements into each other- a feature known in alchemy as the "circulation of the elements," and emphasized and elaborated by Pseudo-Ramon Llull in his Testament, and by George Ripley in his reputed "Wheel of the Elements." Each element has a natural tendency to be transformed into its adjacent element, and so forth. Also, each element acts as a mediator between the element below it and that above it. Aristotle (384-322 BCE) names Thales of Miletus (c. 624 - c. 546 BC) as "the founder of [the Milesian] school of philosophy" (Metaphysics 983b 8-20). Charles Bakewell describes Thales as the originator of the idea that "there must be some natural body ( $\varphi v i \sigma \varsigma)$, one or many, from which all things arise," and "nothing comes into being or perishes, since the primal nature remains ever the same. ${ }^{, 221}$ Everything that is, is merely differentiated out of that primal nature and returns back to it. Aristotle states that "Thales believed that water was that primary substratum." But "Anaximenes and Diogenes held that air is prior to water," and "Hippasus of Metapontum and Heraclitus of Ephesus hold this of fire; and Empedocles — adding earth as a fourth to those already mentioned - takes all four" (Met. I, 984a.5-8). Thales thought of the world as all animated, and that "all things are full of gods" Quite interestingly, Thales' idea of an animated and divine world, combined with his claim that "Magnesian," a magnetic stone, had motive power and a soul, may have contributed to the alchemical use of "Magnesia" as a name for the secret substance and

\footnotetext{
${ }^{221}$ Charles M. Bakewell, Source Book in Ancient Philosophy (New York: C. Scribner's Sons, 1907), p. 1.
} 
root of the stone (which is also the prima materia and Mercury). ${ }^{\mathbf{2 2 2}}$ Thales thought of water as the primary matter, and in alchemy Magnesia is often referred to as water.

To Anaximenes of Miletus (c. 585 - c. 528 BC) Jonathan Barnes attributes the first introduction of the "rarefaction (manôsis) and condensation (puknôsis) into cosmogony, though those particular terms may not have been his own (cf. B 1); and the operations became an orthodox feature of Presocratic science.”223 This twin process of rarification and condensation, became a fundamental part of the alchemical operation, shaping the "circulation" in which the stone undergoes repeated separations of the "rare" or "subtle" from the "dense" or "gross" by evaporation and reunifications by "congelation," between soul—and spirit—and body, until it is "purified." Anaximander of Miletus (c. 610 - c. 546 BC) overcame the conventional mandate to choose one of the four elements as the origin and arche of the others, and posited an undifferentiated chaos as the source of all four. It was infinite, and he referrd to as “'the boundless' or

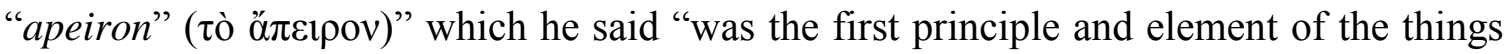
that are." Anaximander was "the first to make use of the term "apeiron" in describing the first principle." 224 Anaximander's "apeiron" as first "principle" or "arche," added to the primal chaos an ambiguous character that made it partly divine, but also partly evil due to its formless infinity. This "apeiron" is the prima materia to which the alchemist must at first regress his "stone" and begin the process of its rebirth and transformation into a microcosm.

\footnotetext{
${ }^{222}$ Kirk and Raven state that in De Anima (A 2, 405 a 19) Aristotle mentions that Thales attributes motive power and soul to Magnesian "because it moves iron" p. 92. See also the fragment from Diogenes Laertius $(\mathrm{i}, 24)$ on p. 94.

223 Jonathan Barnes, p. 43.

${ }^{224}$ Charles M. Bakewell, p. 3; cf. Nikolaos Bakalis, Handbook of Greek Philosophy: From Thales to the Stoics Analysis and Fragments (Victoria, BC: Trafford Publishing, 2005), p. 8, stating that Anaximander was the first to introduce the term "principle" (arch, arche).
} 
After Anaximander, Pythagoras (c. 570 BC - c. 495 BC) adopted the relationship between the bounded, male and good "peiron" and the unbounded, female and evil "apeiron" as the foundation of the structure, harmony and generation of the cosmos and all that is in it. The infinite character of the arche as the material substratum of all that is, was generally shared by the Pre-Socratic philosophers, regardless of the composition that any of them gave it. Another principle that was commonly fundamental in the generation of the cosmos from the arche was the relationship between opposites. Pairs of opposites could be resolved into more inclusive categories, as opposite species resolve into a more general genus. This genus is itself part of a pair of opposites within an even more general genus. It is arguable that the most inclusive pair of opposites was the evil, female infinite and the good, male finite (bounded and possessing form). The relationship between the infinite and the finite continued to be a fundamental principle that shaped the alchemical operation. Empedocles' (c. $490-430 \mathrm{BC}$ ) addition of earth as the fourth element also became the accepted view in alchemy. Empedocles' Love and Strife, which cause the rise and destruction of the things in nature through the association and dissociation of elements, are congruent with alchemy's "conjunction" and "separation" of the stone's constituents. Empedocles', and Heraclitus of Ephesus' (c. 535 - c. 475 BC) unified system of love and strife, and Pythagoras' harmony which joins the male odd number to the female even and open-ended numbers, all become staples of the structure of the alchemical operation. The alchemist imitates-i.e. enacts the steps and in doing so participates in - the genesis of the cosmos. To Heraclitus goes much credit for the "logos," and to Anaxagoras (c. $510-428$ BC), a philosopher Norton seems to favor, goes the credit for the first introduction of "Nous," or "Mind"-although partly contemporary Heraclitus had developed the overlapping idea of the "Logos"-and even more 
interestingly, in connection with alchemy, the idea of the primal chaos as made of "seeds" (spermata). This idea cannot be overestimated in the central role it plays in the metaphorical network of alchemical language. Remarkably, Anaxagoras' paradoxical seeds boast infinite divisibility simultaneously with wholeness, based on the idea that "being" cannot be destroyed, and remains "being," regardless of how far down the scale it is divided, even ad infinitum. His seeds seem to have played an important role in shaping Norton's conception of the alchemical "Stone" itself.

It is worth noting that Empedocles referred to the four elements as "roots,"

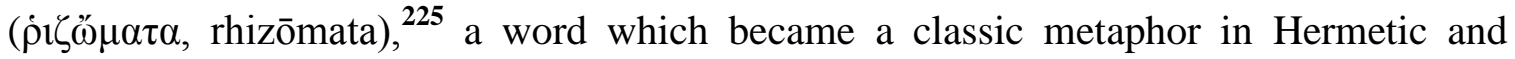
alchemical literature, and which Chaucer uses in the concluding part of his Canon's Yeoman's Tale. "Magnesia" and the many other names given to the ultimate prime matter out of which the stone can be produced, stand for the "root," the most secret and most deeply hidden key without which any attempt at alchemical transmutation is bound to failure. The "root" is the fundamental principle of "generation," hidden within the "arche" of the universe, which the Pre-Socratics conceived of materially, as the fundamental prime matter out of which the entire universe is made. To transmute the stone into a microcosm, the alchemist must begin his operation from the primordial matter out of which the universe was created, and imitate the steps through which it was created. But there was a radical problem: this matter was ambiguous, both good and evil, both divine and infernal.

The ambiguity of the prima materia split reality into a duality through and through. Pairs of opposites combined into more inclusive ones, until reaching the most general pairs. Each pair is resolved into a mean, but then that would be part of a more

\footnotetext{
${ }^{225}$ Kirk and Raven, p. 323
} 
general pair, until the most general is reached. The Pythagoreans regarded the duality as evil, but they accepted it and the 'multiplicity' it implied, as a fundamental part of reality. It was what the infinite, or "boundless," primal chaos was made of. The odd number they regarded as good, since it had an extra "one" which capped the duality and stemmed their infinite deferral. The ultimate "one" or "monad" is the one that capped the entire structure. According to Aristotle, the Pythagoreans contained all binaries into 10 main pairs of opposites:

The elements of number, according to them, are the Even and the Odd. Of these the former [sic., should be "latter"] is limited and the latter [sic., former] unlimited; Unity consists of both [20] (since it is both odd and even); number is derived from Unity; and numbers, as we have said, compose the whole sensible universe. Others of this same school hold that there are ten principles, which they enunciate in a series of corresponding pairs: (1.) Limit and the Unlimited; (2.) Odd and Even; (3.) Unity and Plurality; (4.) Right and Left; (5.) Male and Female; (6.) Rest and Motion; (7.) Straight and Crooked; (8.) Light and Darkness; (9.) Good and Evil; (10.) Square and Oblong ... we can gather thus much, that the contraries are first principles of things. (Metaphysics I, 986a.18-25; 986b.2)

These ten pairs are themselves interchangeable. They are ultimately different names for the same duality, which was a duality of being and non-being. Unlike the Pre-Socratics mentioned above, the Pythagoreans accepted multiplicity and, as such, change. But they ended up with a final 'synthesis' or "golden mean," that united good, which is being, with evil, which is non-being. In other words, the Pythagorean structure of the cosmos treated the nothingness of non-being as though it were something.

The leading Pre-Socratic who most vehemently rejected the Pythagorean duality was Parmenides. Parmenides of Elea, like the Milesian Pre-Socratics mentioned above, rejected the possibility of something new coming into being that was not there before, based on the logic that Being was utterly complete and stable. Nothing could be added to it or subtracted from it. Therefore, anything that arose into individuality was already a 
part of it. When it dies or disintegrates, it merely goes back to the same Being. But Parmenides rejected the pitfall of duality into which the other Pre-Socratics, in general, were mired, even those who rejected change. He vehemently fought the falsehood of treating non-being as though it were something, and argued for a universe based exclusively on Being.

After his above mentioned description of the Pythagoreans, Aristotle proceeds to mention Parmenides. Parmenides, Aristotle argues, was unable to consistently adhere to his own principles (Met. I, 986b.31-35), but Aristotle seems to approve of those principles. Parmenides at least tried to deny opposition between Being and non-being, and make Being alone the first principle of things:

It appears that Parmenides conceived of the Unity as one in definition, [20] but Melissus as materially one.... Parmenides, however, seems to speak with rather more insight. For holding as he does that Notbeing, as contrasted with Being, is nothing, he necessarily supposes that Being is one and that there is nothing else. (Met. I, 986b.19-20; 27-30)

Parmenides had argued that nothing new can come into being. Anything that exists has always been there from the beginning. So Anaxagoras decided to make everything there from the beginning. He therefore made his prima materia of seeds of everything that is or was or ever could be.

But, philosophy had not yet developed the tools to accommodate the reality of change in the world to a concept of Being based entirely on positive grounds. Parmenides insisted, a thing "must either completely be or be not."226 Whatever came and went, therefore, was already a part of being, and remains so. It is only a matter of differentiation, in which like conglomerates with like to produce particular things, or manifestations, and of dissociation, in which the parts are separated and return to the

${ }^{226}$ Kirk and Raven, p. 271. 
whole. Such rejection of coming into being or passing away, true of Pre-Socratics in general, had its most articulate and emphatic expression in the philosophy of Parmenides (born c.510, probable meeting with young Socrates c. 570). ${ }^{\mathbf{2 2 7}}$ Kirk and Raven explain, "Parmenides had maintained that reality cannot come from unreality nor plurality from an original unity. . . . Change in fact is nothing but a re-arrangement." ${ }^{\text {,228 }}$ Aristotle criticized them for their inability to allow any change that was truly "generation" and "destruction" of new beings that were not there before:

Of the first philosophers, then, most thought the principles which were of the nature of matter were the only principles of all things. That of which all things that are consist, the first from which they come to be, the last into which they are resolved (the substance remaining, but changing in its modifications), this they say is the element [10] and this the principle of things, and therefore they think nothing is either generated or destroyed, since this sort of entity is always conserved, (Met. I, 983b.7-12)

Aristotle clearly understands that the "first philosophers" identified "Being" and the "One" with the prima materia itself, our of which everything issued and to which it returned, but without depositing anything new that remains when this cycle is completed. This "material" principle, which "most of the earlier philosophers" posited, Aristotle calls a "substrate" and "primary entity" which "always persists." He describes their idea of it as "that of which all things consist, from which they first come and into which on their destruction they are ultimately resolved." Therefore, for these philosophers nothing can be completely new. Nothing can be generated out of nothing: "nothing else is generated or destroyed." Aristotle names Thales as "the founder of this school of philosophy" (Metaphysics 983b 8-20).

Parmenides' concept of Being as founded on purely positive grounds, was however powerful, and any philosopher who sought to introduce 'change' into the

\footnotetext{
${ }^{227}$ Kirk and Raven, p. 263.

${ }^{228}$ Kirk and Raven, p. 324.
} 
domain of being, had first to account for Parmenides' fundamental principle and be sure not to violate it: Non-being, apeiron or void, are nothing, and cannot account for Being. Only Being can account for Itself. Furthermore, only Being is knowable. Non-being is unknowable because it is nothing. There is in it nothing to know. Aristotle himself, in fact was to make that distinction clearer and more clear-cut through his distinction between "privation," which would apply to the spatial and numerical "apeiron," and "potentiality." Aquinas was later to carry this distinction even further in his insistence, like Augustine before him, that "potentiality" is created, and that God creates out of nothing in an absolute sense, and not in the sense of deriving his creation from something that is a "nothing." Parmenides' rejection of being as based on a dualistic opposition between Being and non-being, leads him to argue that those whose thoughts are based on dualistic principles are living in ignorance and their truths are conditioned by equivocation:

they are two-faced because, as Simplicius puts it (Phys. 117, 3; DK28B6), 'they combine contraries'. It is in fact this very combination of contraries that is the basis of 'the opinions of mortals' (342 1.30 and 3531.51 ) which provide the content of the Way of Seeming; . . . 229

Parmenides' ignorant mortals are not unlike Ripley's false "philosophres" and Norton's "botirflyes." Like them, his mortals too would be conditioned by the impossibility of entitihood, and by deferral. But he explains that they are so because of the duality on which they base their thoughts. Although, therefore, Parmenides could not account for change, his fundamental principle was not to be overlooked. His problem is that philosophy and human language had not yet acquired the tools to put a purely positive basis of Being together with the possibility for something new to come out of nothing. This in turn is due to the fact that it could not yet make a definitive and unambiguous

${ }^{229}$ Kirk and Raven, pp. 271-72. 
distinction between the cosmos and the divine act of creation that brought it into being. If the cosmos was itself Being, and brought itself into being, then nothing new would be possible further than surface "alteration."

Another principle that Parmenides argued, which, though muddled, could not be overlooked, was his identification of Being with knowledge and truth. Parmenides argued that only what is is knowable, and all that which changes is not. He identified knowledge with being in both directions: what is is knowable:

$344 \ldots$. . For thou couldst not know that which is-not (that is impossible) nor utter it; for the same thing can be thought as can be [construction as above, literally the same thing exists for thinking and for being]. " (K\&R 344, Fr. 2, Proclus in Tim. i, 345) ${ }^{\mathbf{2 3 0}}$

At the same time the mind's knowing is identical with the mind's being. Since the mind and the knowledge it knows are the same, and since to know is to know that which is, then we can conclude that there is an intimate identity between the mind and the things which it knows. The mind is the things it knows. If, then, that which changes is not, it can constitute neither knowledge nor the being of the mind.

347 One way only is left to be spoken of, that it is; and on this way are full many signs that what is is uncreated and imperishable, for it is entire, immovable and without end. It was not in the past, nor shall it be, since it is now, all at once, one, continuous; for what creation wilt thou seek for it? how and whence did it grow? Nor shall I allow thee to say or to think, 'from that which is not'; for it is not to be said or thought that it is not. And what need would have driven it on to grow, starting from nothing, at a later time rather than an earlier? Thus it must either completely be or be not. ... How could what is thereafter perish? and how could it come into being? ... So coming into being is extinguished and perishing unimaginable. (K\&R 347, Frag. 8, Simplicius Physics 145, I)

\footnotetext{
${ }^{230}$ Kirk and Raven, p. 296.
}

${ }^{231}$ Kirk and Raven, p. 273. 
Clearly, Parmenides is thinking of Being directly in terms of its divinity, when he ascertains that what is is "uncreated and imperishable." But he is unable to conceive of a relationship between divine Being and particular beings as creatures and not merely individual manifestations and configuration of Being. In Parmenides' logic, if God is uncreated, then nothing else is created. He has not yet arrived at the concept of Being as Creator, since he has not yet arrived at the idea of "will" and of Being as an actant through free will and not through material necessity. In his conclusion that "coming into being is extinguished," Parmenides means that "coming into being" is logically impossible. "That which is not," is the apeiron, which, as void, cannot be responsible for Being. The starting point must be in Being, and not in the void. Being gives rise to being. It cannot be the cause of non-being. Similarly non-being cannot produce being. Parmenides, however, goes so far as to forbid the use of language to deny Being. His position was the diametric opposite of the Pythagorean position which saw the origin of the universe in a combination of good and evil, or being and non-being. For the Pythagoreans, the "first unit had grown by 'inhaling' the void," and that "more and more of Being is constantly coming into existence from the unreal void."232 Pre-Socratic philosophy, then, could either affirm Being, without accepting the possibility of anything new coming into being, or accept that new things are coming into being, but at the expense of making Being dualistic.

Parmenides considered plurality to be no more than non-being. In support of the idea of the non-being of plurality, Zeno, Parmenides' student, produced the paradigms that were to become famous down the ages, including the arrow motionless in flight and the race against the turtle that Achilles cannot win. The former is due to the arrow's

${ }^{232}$ Kirk and Raven, 274. 
constant occupation of its own unchanging length, regardless of the space where it is located or through which it "moves," and the second is due to the infinite divisibility of the distance between Achilles and the (still moving) turtle. Achilles crosses a fractionfor example half —of the remaining distance each time, ad infinitum. Ironically, while Zeno's paradigms came to be understood as illustrative of the incommensurability, absolute divisibility and fragmentation, and absolute relativity of infinity, Zeno had only analyzed infinity in order to banish from being once and for all. He intended his paradigms to prove Parmenides' principle that Being is One and motionless, and that neither motion nor plurality have being. In describing Zeno's argument Aristotle explains: "half-way point[s]" "are unlimited, and it is impossible to traverse things unlimited" (263a4-6). While Zeno only intended to support Parmenides, his problematization of infinity was to remain relevant even through the late Middle Ages. Space is infinitely divisible. In turn, infinity permits no meaningful change. The Infinite divisibility of time, in Heraclitus' saying that one cannot put one's foot in the same river twice, similarly continued to be a popular expression of the problem of identity, entitihood - and as such of the possibility of alchemist's "stone"-in the Late Middle Ages. Even Aquinas mentions Heraclitus' river in connection with the idea of flux: ${ }^{233}$

One of the implications of Parmenides' insistence on the nothingness of nonbeing is that there is no polarity between Being and non-being. In non-being there is nothing for it to engage with in a relationship. There is an absolute and most radical falsehood in attempting to claim a polar relationship between Being and non-being, as opposites, the way occult alchemy, for example, postulates between a good God and an

\footnotetext{
233 "For what is in a continual state of flux, cannot be grasped with any degree of certitude, for it passes away ere the mind can form a judgment thereon: according to the saying of Heraclitus, that "it is not possible twice to touch a drop of water in a passing torrent," as the Philosopher relates (Metaph. iv, Did. iii, 5)." Summa Theologica, I, Q.84.A1, in "I answer that."
} 
evil Matter. Evil is a privation and has no essence. Polar relationships exist between species, or in other words, between 'essences' and 'natures'. They come after Being is already there. Even though, in the pair 'hot' and 'cold', the latter is a degree of absence of the former, it is nevertheless a species. It qualifies a subject. A person can actually feel cold, and everyone knows what it is like to feel cold. 'Cold' has a nature, and like 'hot', is part of the genus 'heat,' or 'temperature,' just as 'night' in St. Gregory's antiphon discussed below, is a part of the entity called "day." Between 'hot' and 'cold' there is, logically, an infinite range of degrees between the two opposites, but both are nevertheless knowable by the mind, since they are essences and 'natures.' Between Being and absolute privation, however, there can be absolutely no range of degrees, either finite or infinite, nor a distance to traverse, as there is between potentiality and actuality. Interestingly, Parmenides foretells the sort of combination that occult alchemy was to make many centuries later. Kirk and Raven explain that fragment 344 suggests that for Parmenides "there are only two 'conceivable ways of enquiry', either a thing is or it is not." But fragments 345-46 mention a third way between the "true way" and the "utterly false way." The goddess warns Parmenides against this third way:

... the goddess (in 345 1. 3) warns Parmenides against treading this path, because, as she goes on to suggest (in 11. 8-9), this utterly false way can be, and constantly is, so combined with the true way that a third way, a compromise between the other two, a thing both is and is not, comes into the picture. This third way is the way on which 'ignorant mortals wander two-faced'; and they are two-faced because, as Simplicius puts it (Phys. 117, 3; DK28в6), eis tauto sunagousi ta antikeimena, 'they combine contraries'. It is in fact this very combination of contraries that is the basis of 'the opinions of mortals' (342 1.30 and 3531.51 ) which provide the content of the Way of Seeming; the premise upon which the whole Way of Seeming rests is just this compromise between the true way and the utterly false way, a thing both is and is not. ${ }^{234}$

${ }^{234}$ Kirk and Raven, pp. 271-272. 
What the goddess is in effect telling Parmenides, is that a dialectic of 'thesis', 'antithesis', 'synthesis' between truth and falsehood, being and non-being, and by implication, good and evil, produces a monstrous falsehood- a duality and equivocation which will condition the lives of those who take that path. This, in effect, would be the judgment Parmenides' goddess would pass against occult alchemy's “Anthropos," since it is based on a prima materia conceived of as both good and evil.

The ideas underlying this judgment have tremendous implications for alchemy, since alchemy bases the thrust of its operation on the relationship between opposites. It implies that for the relationship between opposites to be productive of a fully unified "Philosopher's Stone," free from equivocation, the 'thesis' and 'antithesis' should both be within the domain of Being. Change-once philosophy develops the tools to account for it-should be understood as a relationship between being and being, and not as a relationship between non-being and being, or vice-versa. Evil is not an actant in Creation. Evil is a privation and a condition of being isolated from the possibility of action and of truth. As mentioned above, Aquinas will argue, one and three quarter millenniums later, that we can know privation for what it is only through our relationship with being. We can indeed speak of it truthfully and call it by its name, but this is because we recognize and speak of it by analogy with being. ${ }^{235}$

Parmenides' philosophy was nevertheless muddled. He could not free his system of the duality he vigorously worked to deny, since like the philosophers before him, he did develop, or have at hand, the philosophical tools that could have enabled him to distinguish between divine Being, or the "One," and the primordial chaos. He also conceived of Being spatially, and thus had to deny the possibility of new individual

${ }^{235}$ See footnote 41 , p. 40 above 
beings coming into existence, since they would cause an agglomeration to it over and above its totality, which is impossible, since Being had to be perfect, changeless and absolute. 


\section{Chapter Five}

\section{The Beginning, the End, and the "Meen Space" (Part I): "Generation" within Liminal Boundaries}

\section{Containing Generation Within Creation}

Does Norton base his Pre-Socratic and alchemical trajectory of transformation on opposites that are 'natures', and as such created, or does he base that opposition on a good and evil duality? There are signs, discussed below, that he deliberately tries to base his microcosm on positive grounds, grounds of "creation."

In his description of the union of opposites in lines $2438-42$, he refers to them as "facys," or, in other words, natures, and describes them as "knytt with a knott" by God's own hands:

But Ayer of hir kynde is moste wete. Yett fyre with-oute Ayer worchith nott, For facys of elementis be knytt with a knott Of god his hande, pat thei may not departe Bi noon engyne ne crafte of mannys arte; (V, 2438-42)

The "facys" of the elements are their 'natures' or 'essences,' the rational images or 'faces' by which we recognize them. Thus they are their 'names', in the same sense as the names through which Adam brought things out into knowability in Paradise. These "facys" are knit by God. These "facys" also consist of pairs of contraries. These contraries are "Knytt" together "by ye doctrine of god." Norton describes his philosopher's stone and "Microcosmos" as a union of opposites. But there is no hint in his description, of a good and evil binary duality: 
Noble auctours men of glorious fame

Callide oure stone Microcosmos bi his name,

For his composicion is with-owten dowte

Like to this worlde in which we walke abowte.

Of hete of colde, of moyste \& of drye,

Of harde of softe, of ligth \& hevye,

Off rowghe, of smoth, \& of thyngis stable,

Medlide with thyngis fletynge \& moveable,

Of all kyndis contrarie brogth to oon accorde,

Knytt by ye doctrine of god oure blesside lorde;

Wherbie of metallis is made transmutacion

Not only in colour, but transubstanciacion. (V, 2509-20)

Through Christ, as through the Logos, things are "Knytt" together into meaning and form. By using the word "transubstanciacion," which is the word used for the transformation of the bread into the body and blood of Christ during mass in church, Norton aligns the alchemical operation with the Christian liturgy. The alchemical operation guides the "Stone" through its redemption by the same means that the liturgical mass in in Church guides people to their redemption: the Eucharist. They become part of the transubstantiated bread, or in other words, part of the body of Christ. "Transubstanciacion" also identifies the philosopher's stone, and the redeemed individual with Christ. It is possible that Norton is merely appropriating the language of the Christian faith to alchemy without necessarily transforming the latter. The golden mean is arguably a rational product, and even though it transcends the opposites which it unites. It belongs to the rational mode of perception while Christ's Incarnation transcends the limits of Reason altogether. This may be so. Nevertheless, a mirror that Reason constructs out of its own laws to point to that which is beyond itself, does not negate its analogical truthfulness. The question is, what Norton himself intends in this alignment, and the way he sees it. Did he truly seek to overcome the radical duality in Alchemy's Pre-Socratic, Hermetic, Gnostic and occult heritage? After all, Michael Maier who translated Norton's Ordinal into Latin early in the $17^{\text {th }}$ C., took it back with him to 
Germany along with Ripley's Compound, to introduce there as part of the Rosicrucian movement. ${ }^{236} \mathrm{He}$, in turn influenced Robert Fludd, and the duality of good and evil united in the Stone is fundamental to both. Fludd in turn was a major influence on Jakob Boehme, who perceived God as both good and evil, and as in need of Man to complete himself. Boehme in turn influenced Hegel. Was Maier's dualistic interpretation true to Norton, or did he miss what Norton was fundamentally trying to do: trying to lift the alchemical dialectic from a starting point in an occult duality of good and evil, and enclose it within an unambiguous trajectory that is founded on entirely positive grounds? I continue to present evidence in support of the conclusion that he did intentionally work to do that: transform the alchemical operation by lifting it from a good and evil duality, and by containing it within the wider trajectory of "creation," that begins prior to the prima materia and ends posterior to the microcosm.

One way Norton tried to contain the Pre-Socratic trajectory of the golden mean within the Christian one was by combining the textual content of opposites, degrees, and golden means with a formal movement effected through the poetic verse:

In owre subtile werke of Alchymye Shal be alle colours that hath be seyn with Eye, An hundreth colours mo in certeyne Than evir was in vreyne seyne; wherin so many colours myght not be, But if oure stone conteynede euery gree Of al composicions fownde in werke of kynde, And of al composicions ymaginable bi mynde. Of as many colours as shal therin be seyne, As many graduacions your wisdom most atteyne. (1547-55)

\footnotetext{
${ }^{236}$ Frances A Yates, Rosicrucian Enlightenment (Routledge Classics, 1972, rpt, Psychology Press, Nov 9 , 2001), pp. 250-51. Yates notes that Maier's translation of Norton was published in his Tripus aureus. Frankfurt (Luca Jennis), 1618; and she makes reference to Read, Prelude to Chemistry (London, 1936) pp. $169 \mathrm{ff}$.
} 
The use of degrees and proportions to perfect the Stone is part of Norton's Ancient Greek trajectory. Degrees in particular are based on opposites. Between each genus' opposite poles the range of degrees is infinite. For the stone to be formed, the infinity between each pair of opposite species must be bound and transcended into its golden mean. "Nature many meenes ordeigned" (V, 2408), and "our substance" Norton explains, "is conservid bi vertu of the meene, $(\mathrm{V}, 2047-48)$. The stone contains every degree of color that the eye can see, every degree and combination found in the works of nature, every degree imaginable by mind. The rhetoric in these verses seems simple and discursive. However, the Ancient content of the verses is bound into poetic form by an enactment of form that proceeds from the lower to the higher modes of perception. Norton begins with reference to the sensible gradation of color, visible to the eye: "alle colours that hath be seyn with Eye" (1548), and moves upwards to the rational images, namely species: "al composicions fownde in werke of kynde" (1553). This rational mode of gradation underlies the visible one. Without it "so many colours might not be" (1551), since without species, the mind cannot recognize the images the senses have received. Species are inherent in all possible combinations or "composicions" found in nature. "Kynde" means nature. Every species is a "nature." As in St. Bonaventure's Journey, the mind abstracts the rational species from the sensible image. As we have seen in Ripley's paradigm - taken from Turba Philosophorum and the story of Isis in the Codex Marcianus discussed in Chapter Two above--“nature enjoys nature, and nature overcomes nature." 237 In this paradigm, the higher "nature," abstracted from the lower nature, does not leave that lower nature behind, but carries along within itself. Each is inherent in the other. After that, Norton proceeds to "al composicions ymaginable bi mynde" (1554).

\footnotetext{
${ }^{237}$ See Chapter Two, part IV "Isis and 'Well Conceaved Fruit'."
} 
Within the rational mode, the mind continues to rescue things from infinity, bind them into wholeness as categories, and rise to the next inclusive level, as it climbs up the dialectical ladder of species and genera, all the way up to the widest category which gathers all time and space into a single category. Norton's reference to degrees, and by implication to the "many meenes" (2408) in nature, rises from those perceived by the "Eye" to those perceived by the "mynde," until it includes "al composicions ymaginable bi mynde" (1554). At this point, when the mind has "gathered [all things] together" into a single category of the spatio-temporal mode of perception-regardless of whether it is a 'cosmos', 'world', 'universe' or even many worlds, cosmi or universes-the contemplative pilgrim's being, in Bonaventure's Journey, becomes a fully rounded "microcosm" ${ }^{\text {238 }}$ of all spatio-temporal and natural existence, including all the powers of natural reason. At this point, Bonaventure's pilgrim leaps to God, beyond the limits of his natural and mortal being, and and finally to that perceived through wisdom. So it is for Norton as well, as he proceeds from "mynde" in line 1554 to "wisdom" in line 1556. Line 1556 harks back to all the preceding lines in that movement, or enactment of the journey, and tells the reader and initiate that as many "colours" and "composicions" "that hath be seyn with Eye," that are "fownde in werke of kynde" and that are "ymaginable bi mynde," that's "As many graduacions [as] your wisdom most atteyne." The possible combinations it must encompass are infinite. It is a binding together of no less than infinity. In Bonaventure's Journey, the pilgrim can only perform such a feat through Christ. The pilgrim, in fact, cannot perform any part of the journey except through Christ, since he is the divine Exemplar of all our knowledge, as he unites the

\footnotetext{
${ }^{238}$ See the discussion of Bonaventure's Itinerarium in Chapter Three.
} 
ineffability of the Father with the image of His self-knowledge, and makes this image available to men's minds.

The return to the root in order to grasp the beginning of the universe itself, is the basic logic that underlies the alchemical principle that the stone must at first be decomposed and regressed back to its prima materia. Without regressing it, the alchemist would not be able to grasp the "root" from which the creation of the universe began. This "root" eventually became the medieval Christian alchemist's equivalent of the Word. An indispensable advantage in the 'rooting' of the work in the 'first cause' of existence, is the work's consequent comprehensiveness of all that is, and all that can possibly be involved in the constitution of the universe. This comprehensiveness, as we shall see, Norton presents as crucial to the constitution of "man and oure stone" as a "Microcosmos" $(\mathrm{V}, 1718)$. It is only from that root that the stone will come to contain all the constituents of the universe and to have the dynamic power to include all the operations that these constituents undergo or carry out the transformation- a transformation that must comprehend all the possible combinations among these constituents, infinite as they may be.

With regard to the regress of the stone into the prima materia, it is important to note that Norton shows no signs of the confusion and blending, predominant in occult alchemical literature, of a beginning at the roots of the Cosmos with a primordial "fall" into matter. Occult literature identifies this regress not with the sort of "death" which the stone, like Norton's King, must accept in its rise beyond its mortality towards a personal God, but instead as a fall. When the King crosses his own mortal limits towards God, he sheds off the false sources of his identity in the world, and discovers the source of his identity in God. Like Bonaventure's contemplative pilgrim who holds onto the cross and 
passes through death to the other side, he in fact becomes a microcosm and "Philospher's Stone" whose body, soul and spirit are fully united. His body is transformed from mere matter into a sacrificial body, and part of the body of Christ. Thus Norton uses the word "transubstanciacion" (V, 2519-20) for alchemical transmutation. The Gnostic or occult understanding of the operation would align the stone's "death" back into the prima materia before it rises again, with the fall from heaven to earth. More significantly, this fall would occur prior to creation. Rather, it is the fall of God himself into matter. Consequently, in occult, gnostic and Hermetic alchemical literature, as in Zosimos, ${ }^{\mathbf{2 3 9}}$ or in the Hermetic Poimandres' account of creation, the fall is itself responsible for the first differentiation and generation of individual beings. Matter is evil, God unites Himself with evil, and thus evil plays a crucial role in the occult account of creation. But this would not be "creation" in the Christian sense. Rather it would be "differentiation." The fallen God, who now has a body, will Himself become differentiated into the Cosmos. Since Ancient philosophy conceived of the beginning of the universe on the basis of differentiation, and since Being is a homogeneous and undifferentiated "One," the Gnostic understanding of it would be as a fall from unity into diversity. But since this is what makes all particular forms (individual being) in the Cosmos possible, it is a sacrificial fall on behalf of God. By implication, the fusion of God with matter, and of good with evil, yields the Cosmos. In the artificially induced alchemical operation, this same fusion would yield the microcosm and "Philosopher's Stone." The latter would be an Anthropos, a collective Man, who is greater and more comprehensive than God. This combination logically leads to the loss of the historicity of the particular individual, and thus to his value as an individual. In so far as being an "entity" that transcends the

\footnotetext{
${ }^{239}$ John Reidy in his introduction to Thomas Norton's Ordinal of Alchemy, p. lvii.
} 
opposites of good and evil, it neutralizes not merely the terms of cultural or ideational morality, but fundamentally, and in the case of alchemy, inadvertently, even the difference between creation and destruction. Norton, in comparison with preceding alchemical authors including Ripley, avoids the occult, and no such gnostic confounding of creation with fall is discernible in his work, even though an illustration suggesting such confouunding does accompany his Ordinal in Ashmole's 17thC. Theatrum Chemicum Britannicum (see figure 1 in the Appendix below).

\section{"Lerne this latyne": The Christian Trajectory}

From Norton's "Preface" and "Prohemium," and with the help of the discussion above, we can already glean the outline of the Christian trajectory to redemption, with which Norton intends to align the alchemical one. Its underlying logic can be briefly expounded in the following three steps:

First, In the Preface, Norton establishes a cyclical form for the unfolding of the redemptive operation, one which is ideally simultaneous, while being internally dynamic: The action consists primarily of God's as Creator, with His Act as the source of all creation, and secondarily of man's, as he simultaneously returns to God through Art. Art is the archetype of human action through which man--including all creation through him—seeks God, comes to know Him and to participate in His Act of Creation. Man's creative action through which he returns to God is simultaneous with God's act of creation which gives him being. Man thus participates in God's creation of him, and does so by his own free will, and through his own love and affective and intellectual seeking. The narrative shape of creative action is thus bidirectional, and as such cyclical and involves a free-willed collaborative relationship in which man freely chooses and participates in God's creation of him. 
Second, this bidirectional simultaneity however is lost. Due to the fall, there is a distance to be crossed between man and God, and this distance is infinite. Fallen man is in a condition of deferral, since from birth he is already immersed in the medias res of the beginningless and endless spatio-temporal world and caught in its network of equivocal and deferred referentiality ad infinitum. Norton's long list of alchemical seekers covering all ranks of humanity, can never attain their goal, and yet will never give up their hope. They will continue. As long as they are immersed in infinity, and cannot perform a 'reduction' on it and rise above it, they are in a sort of free fall. There is no stable anchor in infinity to hang onto so that they can change course, make a bend, and, like the ouroboros, turn their course back towards the beginning again, so that they can traverseand simultaneously create - the narrative path back to God. They are powerless unless God will intervene from beyond this infinity.

Third, Norton posits the Incarnation, the event of the leap of Wisdom down to Earth, as the turning-point which enables the human being to bend his course and return back to God. As demonstrated above, he posits the cross as the center of a golden England. The King must turn to God for help and redemption. He must be able to die to self and world, and leap towards God, across his own mortal limits, and he can only do that through the Cross. During his description of transmutation in Chapter V, Norton uses the word "transubstanciacion" to distinguish the true and kind from a merely sensible transmutation that is "only in colour" (2519-20). Transubstantiation is the word used for the transformation of Eucharistic bread into the body of Christ during mass. Norton's distinction implies that the true transmutation is rooted in Christ, and not in the spatio-temporal world. As implied in his advice to the King discussed above, the stone 
must cross its own mortal limits, root its own intentionality in God and become an agent of His act of Creation.

In Chapter VI, in describing the "concord" that must be between the alchemist's "werke" and his "mynde," Norton makes a powerful allusion to the Incarnation as the agent that enables the alchemist to "procede myghtly to the ende / Fro the begynnynge, magre the fende" (2723-24). It is important to investigate the implications of this allusion, since through it Norton brings to his own text the powerful contexts of the liturgical year and its beginning in advent, the "leap topos" and the wisdom literature of the Old Testament, particularly the books of Wisdom and Ecclesiasticus, and finally the cyclical operations of nature itself, which the alchemist claims to be the material substance of his art.

In the Ordinal's fourth chapter, Norton expounds "V. Concordis" which "he moste vndirstonde" who "will take our werke in honde" (2989-2990). The first concord concerns "Whethir his mynde accorde with the werke," the second is "Bitwen this crafte and hirr werkmen," the third is "When werke concordith with Instrumentis," the fourth is between the work and "ye place where it shall be wrogth," and "The vth is of concorde and of love/ Bitwen your werkis and the spere above" (VI. 2991-3004). It is in connection with the first concord that Norton makes the above mentioned allusion. Norton gives stability of mind as the key to the concord between the alchemist's mind and his work. "Full fewe lordis be stable of mynde" (3008). Such people who cannot rise above the flux of the sensible world easily change their minds or give up, and will not last through the work. "Late such like botirflyes wandir and passe," and as for you, "lerne this latyne both more and lasse (3009-3020):

Late such like botirflyes wandir \& passe, And lerne this latyne both more \& lasse, 
Folowinge the sentence of this holy letter: Attingens a fine vsque ad finem fortiter \& disponens omnia suaviter;

That is, procede myghtly to the ende Fro the begynnynge, magre the fende, All thyngis disposinge in the meen space With grete suauyte that comyth of grace. (VI, 2719-26)

There is the stroke of a master in his choice of "this latyne" to signal the key to stability and to ensurance against submission to flux and relativity—due to the contexts it brings to bear on his text and the alchemical process. It alerts his perspicuous reader to the significance of beginnings middles and ends. He cunningly guides his reader to the principle that enables the stone to traverse the distance of the redemptive process from the motivation that inspires it into motion, to its ultimate intentional goal, namely the Incarnation, particularly in its character as the leap of Wisdom down to Earth. "This latyne" he advises his reader to "lerne" comes simultaneously from three texts: the first is the antiphon "O Sapientia," one of the original and oldest seven advent antiphons popularly known as "O antiphons" and often attributed to, or connected with, St. Gregory the Great $(540-604)^{240}$ :

O Sapientia, que ex ore Altissimi prodiisti, attingens a fine usque ad finem, fortiter suaviterque disponens omnia: veni ad docendum nos viam prudentiae. ${ }^{241}$

O WISDOM, That proceedest out of the mouth of the Most High, reaching from end to end mightily, and sweetly disposing all things: come and teach us the way of prudence! ${ }^{242}$

\footnotetext{
${ }^{240}$ Susan Rankin , "The liturgical background of the Old English Advent lyrics: a reappraisal." See note 183.

${ }^{241}$ William J. Deane, Sōphia Salomon. The book of Wisdom; the Greek text, the Latin Vulgate, and the Authorised English version (Oxford: The Clarendon press, 1881), in his notes on 8.1, p. 153; cf. Sacrae biblia in quo continentur quinque libri Moysi, libri Iosue, et Iudicum, liber Psalmorum, Prouerbia, Salomonis, liber Sapientie, et Nouum Testamentum Iesu Christi (London: Thomas Bertheletus July 1535), p. 175 (image 188 at http://eebo.chadwyck.com); cf. Rev. Matthew Britt O.S.B., ed., The Hymns of the Breviary and Missal, pref. by Rt. Rev. Msgr. Hugh T. Henry (London: Burnes Oates \& Washbourne Ltd. 1922), 91.

${ }^{242}$ Ibid., 34.
} 
Norton's Latin quotation would have been easily recognizable by his contemporary readers, especially since people were commonly all church-goers. "O Sapientia" consists of lines 24:5 and 8:1 from the Old Testament wisdom books, Ecclesiasticus (also known as Sirach) and Wisdom, respectively. ${ }^{243}$ The Latin Vulgate gives Wisdom 8:1 as "Attingit ergo a fine usque ad finem fortiter, et disponit Omnia suaviter." The word "ergo," connects this first verse of chapter viii with the last verse of chapter vii. The book of Wisdom enjoyed the attention of numerous commentators during the long Middle Ages. ${ }^{244}$ This line in particular, made popular by the antiphon, was often quoted or alluded to. It was, though, alluded to even before the time of St. Gregory, by Boethius (c. 480-c. 524) in his Consolation of Philosophy. ${ }^{245}$

These seven antiphons were sung during the last seven days of advent vespers (evening mass), all beginning with the interjection "O." Each was designated for one of those seven days preceding the Christmas vigil, and ending in the birth of Christ on the eighth evening, and they are available in the Roman Breviary. They were attached to the "Magnificat" and sung probably before it and after the reading from the Psalms, thus, after the Old and in anticipation of the New Testament. This would be one of the dimensions of the antiphon's location between an end and a new beginning. Of these

\footnotetext{
${ }^{243}$ In addition to Wisdom 8.1, and Ecclesiasticus (Sirach) 24.5, there are several partial analogues in the Old Testament and New Testament. These include, but may not be limited to, Wisdom ix. 4, 9, 10, Proverbs viii. 22, Hebrews i. 1; and John i. 3. Tthe part of the antiphon Norton quotes derives from Wisdom 8.1.

${ }^{244}$ These included Psuedo-Dionysius the Areopagite (late 5th to early 6th c.), Rabanus Maurus (c.780-856) Cynewulf (c. $9^{\text {th }}$ c.), St. Bonaventure (1221-1274), St. Thomas Aquinas (1225-1274), and Hugh of Balma $\left(13^{\text {th }}\right.$ C.) among many others who commented on it as a whole or in parts.

${ }^{245}$ William J. Deane, Söphia Salomon. The book of Wisdom; the Greek text, the Latin Vulgate, and the Authorised English version (Oxford: The Clarendon press, 1881), in his notes on 8.1, 153.
} 
seven, the antiphon which Norton quotes, "O Sapientia," holds a special place, since it is designated for the opening day of these seven, December $17^{\text {th }}{ }^{246}$

Norton thus would have been familiar with "this latyne" not only through his education, but through his much more modest activity as a common churchgoer. While Latin is the language that only the educated can understand, Norton pulls it down from its heights and places it in the daily life of common man. As elevated as Latin may be, the Latin of "O Sapientia" would have been homely in its familiarity to churchgoers since the early Middle Ages, and would have still been familiar and homely well beyond Norton's time. Norton's allusion would thus be recognizable to his readers in general, and part of their experience during Advent vespers and of their affective memory. Therefore, while Norton proposes it as an education ("lern[ing]"), "this latyne" is in fact in keeping with the humble spirit of vernacular poetry: It speaks directly to the common man, and in the phrase "both more \& lasse" (2720) Norton's treats the "more" to the same lowly wisdom as the "lasse." It is not a far-fetched question whether Norton had in mind to associate his vernacular style with God's humility in His leap down to Earth-especially that the antiphon is a call for Him to come down to Earth and transform it - or perhaps with Virgin Mary's humility as His lowly maiden, especially since the "O" antiphons were specifically linked to the "Magnificat." But this would be one among the allusion's several other contexts that are more directly connected with alchemical themes.

The discussion will begin with some of the textual context that "O Sapientia" brings to Norton's Ordinal, and then follow this with a treatment of the liturgical context.

\footnotetext{
${ }^{246}$ The Roman Breviary translated by John Marquess of Bute allocates "O Wisdom" for the $17^{\text {th }}$ of December: The Roman Breviary: reformed by order of the Holy cumenical Council of Trent; published by order of Pope St. Pius V; and revised by Clement VIII., Urban VIII., and Leo XIII; together with the offices since granted and the martyrology (Edinburgh: W. Blackwood, 1908), 244. William Dean, in his notes to Wisdom 8:1 allocates it to December $16^{\text {th }}$. The disparity bet the $17^{\text {th }}$ and $16^{\text {th }}$ would be due to a later addition of an eightht antiphon.
} 
Immediately after line 8:1 which Norton quotes, the text of the book of Wisdom proceeds to link Wisdom to the theme of the soul's marriage to God, reminiscent of the "Song of Songs":

2 I loved her, and sought her out from my youth, I desired to make her my spouse, and I was a lover of her beauty. 3 In that she is conversant with God, she magnifieth her nobility: yea, the Lord of all things himself loved her. 4 For she is privy to the mysteries of the knowledge of God, and a lover of his works. 5 If riches be a possession to be desired in this life; what is richer than wisdom, that worketh all things? 6 And if prudence work; who of all that are is a more cunning workman than she? (Wis., 8:26) 247

In connection with alchemy, the marriage theme of Wisdom 8:2 would be a reference to alchemical transmutation as a "hierosgamos" or "alchemical marriage" between Sun and Moon or Sulphur and Mercury. As in Arnold of Villanova's Rosarium Philosophorum, this is a marriage not only between male and female, but also between divinity and man. Norton, however, avoids occult terms throughout his Ordinal, unlike Ripley who liberally and profusely uses them. Rather, his allusion stresses the Biblical aspect. At the same time, through the contextual statement, in 8:4, that Wisdom is "privy to the mysteries of the knowledge of God," Norton would be referring to the "pryvete" which Chaucer says, in the Canon's Yeoman's Tale that God will give only to whom he chooses. "Wisdom" in Norton's textual allusion is definitely divine and an act of free will rather than a mechanical result of a process. The Christian understanding of her as God's Word is supported by the idea, expressed both in Wisdom and Eccleisasticus, that she was there with God when He created the world. ${ }^{\mathbf{2 4 8}}$ "For wisdom, which is the worker

\footnotetext{
${ }^{247}$ From Sōphia Salōmon, pp. 66-67: 2 Hanc amavi, et exquisivi a juventute mea, et quaesivi sponsam mihi eam assumere, et amator factus sum formae illius. 3 Generositatem illius glorificat, contubernium liabens Dei ; sed et omnium Domiuus dilexit illam ; 4 doctrix enim est disciplinae Dei, et electrix ope-rum illius. 5 Et si divitiae appetuntur in vita, quid sapientia locupletius quae operatur Omnia? 6 Si autem sensus operatur, quis horum quae sunt magis quam ilia est artifex?

${ }^{248}$ Sōphia Salōmon, p.
} 
of all things, taught me: for in her is an understanding spirit, holy, one only [Gr.: monogenes "only begotten"], manifold, subtil, lively, clear, ... stedfast, sure, free from care, having all power, overseeing all things...." (Wis. 7:22), ${ }^{\mathbf{2 4 9}}$ and in the line completing Ecclesiasticus 24.5 she is the "primogenita ante omnem creaturam" "the firstborn before all creatures." ${ }^{\mathbf{2 5 0}}$ It is worthy of note that Norton's allusion to the OT wisdom literature places the God's Word before his creation even of the primal chaos, as opposed to Ripley's placing it after the Word in his Compound's account of creation. ${ }^{\mathbf{2 5 1}}$ Norton would thus be portraying the secret and divine knowledge which alchemical texts hide within them — and to which he is guiding his reader — as being unambiguously rooted in a Truth that is ontologically prior to nature. It is thus beyond the ken of those "botirflyes" limited to the natural mode of life and knowledge. Also, in connection with 8:5, Norton would be referring to the theme of the allegorical relationship between material and spiritual gold. The prizing of wisdom over material riches would not repudiate the alchemical seeker's practical work to produce material gold. Rather, it would support and direct it, since "prudentiae" in the antiphon's call "veni ad docendum nos viam prudentiae," is the ability of the receiver of divine Wisdom to weave it into the practical world through his art. This idea would be supported immediately by the next line, 8:6, which would be a reference to the alchemical operation in its capacity as art: it describes

\footnotetext{
${ }^{249}$ Sōphia Salomon, p. 65. This book provides the Greek text in parallel format with St. Jerome's Latin Vulgate and the "Authorized English" texts. Dean notes that the Greek text reads "only begotten."

${ }^{250}$ The Latin translation comes from the Douay-Rheims Bible: Biblia Sacra Iuxta Vulgata Versionem (Editio quinta) (Based on the Old Testament edition of the Benedictines of St. Jerome's Monastery in Rome, and the New Testament edition of Wordsworth and White, GBS, Stuttgart, 1994, 4th Ed.), eds. Robert Weber and Roger Gryson, ( Stuttgart: Deutsche Bibelgesellschaft, 1994).

For the English translation I have used: The Holy Bible translated from the Latin Vulgate: diligently compared with the Hebrew, Greek, and other editions in divers languages : the Old Testament first published by the English College at Douay, A. D. 1609, and the New Testament first published by the English College at Rheims, A. D. 1582, published with the approbation of James Cardinal Gibbons (Baltimore : John Murphy Company, c1914).

${ }^{251}$ See the discussion of these verses in Chapter two above, "Allegory and Allegoresis in Ripley's Compound."
} 
Wisdom as a "cunning workman," and thus adds the idea of art to her description in line 8:1 as "disponens omnia," ("disposing all things"). Norton's allusion to this text in connection with alchemy implies that the alchemist's art is really ordered and wrought by divine Wisdom. Like Ripley as argued in Chapter One above, Norton also views the alchemist as an agent of God's act of creation. Thus Norton's allusion to Wisdom affirms alchemy's central themes, but with emphasis on the Biblical instead of the occult aspect.

The relevance of the OT book of Wisdom to the role of art in the trajectory of redemption, and especially to the themes that alchemy claims for itself, is a very rich topic that can only be hinted at in this study. Among its themes relevant to Norton's Ordinal is its political one reminiscent of Norton's advice to King Edward IV or to his successors: " 20 Therefore the desire of wisdom 21 bringeth to a kingdom. If your delight be in thrones and sceptres, ye kings of the people, honour wisdom, that ye 22 may reign for evermore" (6:20-22). Another instance of common themes is the author's promise that he will disclose the hidden knowledge to his reader: "I will tell You, and will not hide mysteries From you: but will seek her out from the beginning of her nativity, and bring the knowledge of her into light, and will not 23 pass over the truth" (6:22-23).

However, the main and most inclusive allusion that Norton is making through "this latyne" is to the Incarnation. In the first line of the antiphon, the phrase "que ex ore Altissimi prodiisti" describes Wisdom issuing out of God's mouth. From a Christian viewpoint, it connects Wisdom directly with Christ as the Word, as in the opening of St. John's Gospel. The phrase itself derives from Ecclesiasticus (Sirach) 24:5, in which Sapientia herself speaks: "ego ex ore Altissimi prodivi primogenita ante omnem 
creaturam.. ${ }^{252}$ This line combines the Incarnation with the Creation in its leap topos, a combination which, as mentioned above, Cervone argues is common in medieval literature. Sapientia was the first that issued out of the mouth of Most High, and was there before all his creation. God is the "root" of Wisdom in the question in Ecclus, 1.6: "radix sapientiae cui revelata," ("To whom hath the root of wisdom been revealed. .?") ${ }^{253}$ The word "root" is part of the vocabulary alchemy uses for the deepest hidden knowledge, and the foundational key of the operation.

In addition to the Incarnation, there is another feature of Wisdom in both these OT books, which is crucial to Norton's project of aligning the Ancient with the Christian trajectory. This is the principle of the absolute comprehensiveness of Wisdom's power: it has power over everything and orders everything from beginning to end. Norton wants his Ordinal, likewise, to proceed "All thyngis disposinge" with "grete suauyte that comyth of grace." Wisdom precedes Creation, and its reach over all Creation is complete. Nothing is beyond its reach. In the next three lines of Ecclesiasticus following 24.5, Wisdom says about herself: "gyrum caeli circuivi sola et in profundum abyssi penetravi et in fluctibus maris ambulavi in profundum abyssi penetravi." She encompasses the heavens and penetrates the profundity of the abyss. In other words, she encompasses creation from its "beginning" to its "end" and both pre-exists the beginning, and transcends the end:

5 ego ex ore Altissimi prodivi primogenita ante omnem creaturam 6 ego in caelis feci ut oriretur lumen indeficiens et sicut nebula texi omnem terram 7 ego in altis habitavi et thronus meus in columna nubis 8 gyrum caeli circuivi sola et in profundum abyssi penetravi et in fluctibus maris ambulavi (Ecclus. [Sirach] 24.5-8)

\footnotetext{
${ }^{252}$ Biblia Sacra Vulgata (Based on the Old Testament edition of the Benedictines of St. Jerome's Monastery in Rome, and the New Testament edition of Wordsworth and White, GBS, Stuttgart, 1994, 4th $E d$.), eds. Robert Weber and Roger Gryson, quartam emendatam edition, Deutsche Bibelgesellschaft; Ed. (1983), http://www.latinvulgate.com/verse.aspx? $\mathrm{t}=0 \& \mathrm{~b}=26 \& \mathrm{c}=24$, or http://www.amazon.com/dp/3438053039/ref=rdr_ext_tmb.

${ }^{253}$ Ibid.
} 
I came out of the mouth of the most High, the firstborn before all creatures: 6 I made that in the heavens there should rise light that never faileth, and as a cloud I covered all the earth: 7 I dwelt in the highest places, and my throne is in a pillar of a cloud. 8 I alone have compassed the circuit of heaven, and have penetrated into the bottom of the deep, and have walked in the waves of the sea....

As we have seen, and shall again see below, Norton repeatedly emphasizes the idea that the alchemical "werke" must cover the entire ontological structure of the created world, and to do that he must receive wisdom from beyond the natural world. His work must begin and end in the leap topos. Its beginning and end must be an event that is modal in its nature: Rather than deriving from the temporal nexus, the work's beginning and end must be the modal beginning and modal end of time itself, so that "oure stone" will be a "Microcosmos" (V, 1718). The alchemist must adopt as his own, the trajectory of divine Creation itself, and trace its steps. Just as God created all through His Wisdom, so must the alchemist create, not merely through his own mind, but through God's Wisdom, which was there with God before creation. This means that the alchemical artist must begin his work before creation as well:

Therfore, seid morien, our stone in generacion Is moste like thing to mannys creacion; In whom, seith Raymonde, the iiij degrees all Of the iiij complexions to-gedir fynd ye shall; And that actually, which ye can not fynde Among creaturis in none othir kynde; wherfore a-monge creaturis these $\mathrm{ij}$ alone Be callid Microcosmos, man \& oure stone. (V, 1711-1718)

Norton's insistence here and elsewhere on the stone's encompassing the whole range of degrees of all the components of being, is part of Norton's way of aligning the Pythagorean-influenced Pre-Socratic philosophies with Christian doctrine. The care Norton takes to shift the meaning of "generation," 254 deriving from Pre-Socratic natural

\footnotetext{
${ }^{254}$ To this day, masonic emblems carry the letter "G," which stands not for "God" but for "Generation."
} 
philosophy—-from one that displaces creation, where there is no such thing as creation out of nothing, to one that imitates "creation," shows that he is aware of the distinction that Aquinas, and probably several others, have made, between "generation" and "creation." In fact this idea is fundamental to his entire attempt to align alchemy's Pre-Socratic roots with Christian doctrine. Aquinas takes up Pre-Socratic philosophers, and even Aristotle, in his arguments in his Summa Theologica, and makes a radical distinction that cannot possibly be smoothed away, between "generation" and "creation," the former beginning in the prima materia and ending - if successful —in the prima materia transformed, the latter in beginning God's Act of creation out of nothing, and ending in God beyond the perfected product into which the prima materia has been transformed. Norton wants to base his opus on creation. But at the same time, he wants to unite alchemy, and its language of generation, to the Christian doctrine of creation. Lines 11711-12 emphasize the ontological inclusiveness of the stone, but their language is careful. Norton does not say generation is creation. Rather he quotes Morienus saying that it is like creation. By likening generation to creation, he is also distinguishing between them. Man's art imitates God's art. God creates man and man generates the stone. In so far, though, as the work of the artist is by participation in God's, the stone is not only man's work, but also God's. Norton seems to be couching the narrower "generation" within the wider "creation," both together producing the Stone.

Norton's allusion to an advent antiphon brings to his text not only its Biblical contexts but also its liturgical context. In its liturgical context "O Sapientia" serves the Ordinal's alignment project by bringing the alchemical trajectory together with both the sacred History of Creation and the cycles of nature with which the liturgy combines it. Also, as a herald of the coming birth of Christ, the antiphon serves to connect the 
alchemical operation with the Incarnation. At the same time, through its participation in the liturgical mass, it connects the alchemical operation with the Eucharist being celebrated during mass - the sacrificial and soteriological body of Christ—and as such not only with Christ's birth—his first coming — but also with his death, harrowing of Hell, Resurrection and finally second coming and the resurrection of the dead. As a call and herald for the coming of Christ and the new year, the antiphon is a call for both natural and spiritual renewal, and anticipates both of Christ's comings, at Christmas and at the end of the world. Through his allusion to the "O Sapientia," therefore, Norton associates the beginning and end of the alchemical operation with the beginning and end of the natural year, the liturgical year, the birth and death of Christ, as well as the beginning and end of the world. In doing so, Norton aligns with all these cycles the most ancient prototype of the sacred History of Creation, which survives through alchemy's natural philosophy, namely the Pre-Socratic account of the Cosmic cycle's 'differentiation' from and return to the "One." This cosmic cycle, alchemists represent in their emblem of the ouroboros, the serpent or dragon whose tail is in its mouth.

In this alignment, however, Norton is making a vast and radical intellectual leap from a cycle which begins and ends in material nature - the equivocally divine prima materia - and a cycle which begins and ends in the topos of the leap down to Earth of a divine Wisdom from heights and depths that are radically beyond nature, including its prima materia, and beyond the ken of natural knowledge altogether. Norton's intended alignment of the alchemical operation with the sacred History of Creation-which is the sacred History of mankind and the divine act of Creation of the universe from beginning to end - betrays his awareness of this radical difference between the "root" of "magnesia" in the prima materia, and the root of the Christian account of the universe in ineffable 
divine depths that infinitely transcend nature and the mind altoghether. The evidence of such awareness on his behalf, logically leads to the conclusion that Norton sought to break the alchemical operation free from the mechanical laws of material necessity within which its Pre-Socratic roots tend to limit it, and to lift it into the radically more creative cycle of the Christian Cosmos. The events of beginning and end of the latter in a Christian God infinitely transcend the events of beginning and end of the former in the primal chaos, or "arche" ("arch") and "apeiron" ("apeiron").

The alchemical cycle -which the traditional emblem of the ouroboros expresses, is essentially a material one, and matter, as Aristotle-and Norton's favored Anaxagoras - assert, is infinitely divisible. The ouroboros, the snake or dragon which curls its length back upon itself, and has the tip of its tail back in its mouth, expresses the undifferentiated unity of the prima materia, the Pre-Socratic primordial arche and ambiguous "One" who is both good and evil, the apeiron and unlimited void, and at the same time the "material substratum" out of which everything in the cosmos is differentiated into individual forms and combinations, and back into which everything decomposes again. The ouroboros represents a similar idea to that in Ancient Alcmaeon's statement quoted in the incipit: its end meets back with its beginning and allows life to go on. However, through the unity of the ouroboros no indivudal being can survive. It is only the undifferentiated primal chaos, identified with an impersonal Wold Soul, which continues, or, in the best case, an impersonal or collective "golden mean" between the two.

In Norton's alignment project the "leap topos" also turns the Christian sacred history of Creation back upon itself from an exitus into a reditus, and into a circle whose end meets its beginning. But those beginning and end events are utterly non-derivative 
and free willed acts of love. There is no necessity in them. The ouroboros, or the arche that Aristotle describes as the "material substratum" by means of which the Pre-Socratic cosmos ensures the continuity of its being through the continual flux, is no more than flux or pluralistic apeiron itself. The Christian cyclical trajectory of Creation offers a personal God who preserves the individual being beyond death, as ineffable transcendent 'stratum', whether considered 'sub-' or 'super-', which preserves the unity and identity of the individual—and "stone"- through both the ongoing condition of "death" caused by infinite divisibility of time, space and matter, and the actual bodily death of the individual, and his passing away not merely from "form" to return to matter, as in the Ancient cycle, but from the natural and material universe altogether. By identifying the alchemical cycle with the Christian cycle of the liturgical year, Norton lifts it up from the context of material necessity and places it in the context of free will, and from the context of "generation," which has the narrow range from prima materia and back to prima materia, where individual identity is completely dissolved, to the context of the radically wider and radically more inclusive "creation," where, even as they repeat, the cycles deposit indelible individual beings, and irreversible historical events.

Alchemy is an art that employs the operations and laws of nature to arrive at its artistic opus. Its art and science are one. If the scientific laws of nature are based on divine Wisdom, love and free will, and not on necessity, and if the dawn comes back out of the night through divine Will in the same way as Creation comes out of nothing, then alchemy itself would similarly be based on the same grounds of freedom. Christian doctrine, especially as discernible through the leap topos, presents a nature whose cycles are impossible to complete mechanistically and whose nights and days, winters and springs, are connected through the Will and Wisdom of God. One of the most well- 
known antiphons, the creation antiphon "Lucis Creator optime," which is, like the seven original advent antiphons--or perhaps more surely--believed to be composed by St. Gregory the Great (540-604), describes God pulling the light out of the primordial darkness on the second day of creation, and parallels this with the description in the next verse, of His joining (iunctum ) of the evening back with the morning, and naming them both "day." It is one of a series of hymns dedicated each to one day of the creation story of Genesis. It celebrates God's creation of light, and is sung on the first Sunday after Epiphany and the first Sunday after Pentecost, during the evening Vespers ${ }^{255}$ :

\begin{tabular}{|c|c|}
\hline $\begin{array}{l}\text { Lucis Creator optime } \\
\text { Lucem dierum proferens, } \\
\text { Primordiis lucis novae, } \\
\text { Mundi parans originem: }\end{array}$ & $\begin{array}{l}\text { O blest Creator of the light, } \\
\text { Who makest the day with radiance bright, } \\
\text { And o'er the forming world didst call } \\
\text { The light from chaos first of all. }\end{array}$ \\
\hline $\begin{array}{l}\text { Qui mane iunctum vesperi } \\
\text { Diem vocari praecipis: } \\
\text { Illabitur tetrum chaos, } \\
\text { Audi preces cum fletibus. }\end{array}$ & $\begin{array}{l}\text { Whose wisdom joined in meet array } \\
\text { The morn and eve and named them Day, } \\
\text { Night comes with all its darkling fears; } \\
\text { Regard Thy people's prayers and tears. }\end{array}$ \\
\hline $\begin{array}{l}\text { Ne mens gravata crimine, } \\
\text { Vitae sit exsul munere, } \\
\text { Dum nil perenne cogitat, } \\
\text { Seseque culpis illigat. }{ }^{256}\end{array}$ & $\begin{array}{l}\text { Lest, sunk in sin, and whelmed with strife, } \\
\text { They lose the gift of endless life; } \\
\text { While thinking but the thoughts of time, } \\
\text { They weave new chains of woe and crime. }\end{array}$ \\
\hline
\end{tabular}

Not only does God connect the evening back to the morning, but with his voice he also gives both the same name, and their name is good: it is "day." The primordial chaos, as well as the daily night are lifted up from a privation, and given the status of creation. The night is a comprehensible, created and natural part of the day- no longer a scary and evil apeiron. That, the apeiron, is no thing whatsoever. Night is now a created part of the day. It is not no thing. In the third stanza the antiphon shifts privation from an assumed

\footnotetext{
${ }^{255}$ Both Latin original and English translation are from Mathew Britt, The Divine Office a Study of the Roman Breviary, Dublin: M. H. Gill \& Son, Ltd., 1920, 211. Mathew Britt's English version is truer and more ssensitive to the Latin original that other available translations or English versions of the antiphon. ${ }^{256}$ Matthew Britt, The Hymns of the Breviary and Missal, 74.
} 
natural effect to an effect of sin. It is a matter of the will. It also attributes people's evil or illegitimate deeds to their thinking "thoughts of time," or, in other words, to the limitation of their minds, goals and desires to temporal effects and partial goods. The Latin word "perenne" signifies unending continuity, but it is a temporal continuity, and the verse ironically associates this endless continuity with the loss of "vitae," "life," instead of with retaining it, as that continuity in time may seem to suggest to those such as Norton's "botirflyes," and Ripley's false "philosophres." St Greagory's "Lucis Creator optime" lifts even the natural cycle out of mechanical necessity and places it in the hands of God.

The awareness that Norton exhibits has no presence in Hermetic literature or in that of its many adherents. "Wisdom" in Hermetic literature, derives from the primal chaos. In the seventeenth century English medic William Salmon's (1644-1713) translation of "The Tractatus Aureus" attributed to Hermes Trismegistus into English, Hermes makes a reference to Aristotle's accusation that the early philosophers' first cause was merely material, and rejects it. He insists that his four elements are not corporeal, as the "Peripateticks," i.e., Aristotelians, claim. They are spiritual. Nevertheless, he locates the roots of wisdom in the "Prima materia," which is only one although it has many names, which itself is Mercury, and "which is the beginning, the middle and the end of the Work":

Salmon. Hermes now belgins to give a description of the Great Work, which he calls the knowledge of the Elements, but not of those Elements which are foolish|ly discoursed of in the Schools of the Peripateticks: They speak of an Element to be Corpus Simplex, but our Hermes saith, They are not to be understood Corporalliter. Ergò 〈in non-Latin alphabet $>$ i. e. Spiritualiter \& Sapienter, that is, Spiri|tually and Wisely. Thus the Principles of Art are said to be four Elements, Earth, Water, Air, Fire, as Hermes indicates .... The Aqua Philosophica: There are malny other Names by which this Matter is called, but the Subject, or Prima mate|ria, 
is one only: because it is, as it were, the Cardinal hinge upon which all the rest turn, which the Philo|sophers explicate to be their Mercury, which is the be/ginning, the middle, and the end of the Work, and without which, whoever labours, labours in vain ... [the emphasis is my own]. ${ }^{257}$

It is important to note that "Mercury"-who is himself the dragon and the prima materia, which in turn is the root of wisdom-is not only the beginning and end of the work, but also its middle. This is because he is not only the prima materia in its primordial form, but also in its wrought and transcendent form as the 'third term' and golden mean which is at the center of the work. Mercury is also the mediator. Logically, the presence of Mercury at the center implies that he is the one who enables the path of the operation to bend back upon itself-from an infinite falling away into matter--and become cyclical, returning to its origin. Mercury is himself the beginning, middle and end, Mercury is the ouroboros, and the ouroboros is the shape of the successful alchemical operation, it follows that this shape is made possible also by Mercury. He is the one who mediates between the exitus and reditus of the work from the prima materia and back to it. As confused as this sounds, it is correct, since alchemical literature frequently reiterates that Mercury is the entire work in all its phases. Nevertheless, the location of Mercury in the middle at the turning point of the work-enabling the ouroboros' tail to turn back upon itself and place its tail back into its mouth—is comparable to the Incarnate Christ through Whom God pulls his creatures back to Himself. But Christ does not mechanically turn people around back to God. Rather, while providing the way for the return, he leaves the

\footnotetext{
257 Hermes and William Salmon, Hermetis Trismegisti Tractatus Aureus: The Golden Work of Hermes Trismegistus; Translated out of Hebrew into Arabick, then into Greek, afterwards into Latin; and now done out of Latin into English, Claused, and largely Commented upon, By WILLIAM SALMON, in William Salmon, et al., Medicina practica, or, Practical physick shewing the method of curing the most usual diseases happening to humane bodies ... : to which is added, the philosophick works of Hermes Trismegistus, Kalid Persicus, Geber Arabs, Artesius Longavus, Nicholas Flammel, Roger Bachon and George Ripley : all translated out of the best Latin editions into English ... : together with a singular comment upon the first book of Hermes, the most ancient of philosophers: the whole compleated in three books / by William Salmon ... (London: Printed for T. Howkins, J. Taylor and J. Harris, 1692) pp. 181- 82.
} 
individual free to choose this return. Sacred history is the history of the unfolding and completion of a single divine Act in which all creation participates in its varying degrees, with the participation of man as the culmination of the participation of nature and everything in it. The cyclical way nature behaves-including its days, months, seasons and planetary revolutions-is shaped by its own participation in that act.

In a contemporary and passionately written book on the "O" antiphons, the author, Oliver Treanor, gives expression to the identity that the events of sacred History share with each other as parts of a single act of Creation in his comments: the advent antiphons, while being "true to the spirit of the readings" for the Christmas season, are also part of the mass celebrating the Paschal Lamb. Therefore the Advent which the "O" antiphons call for, he argues, anticipate not only the incarnation at Christmas, but also Jesus' death and resurrection at Easter as well as his last coming and our own resurrection: "Here is all Advent in Sacrament; his coming, his birth, his death and resurrection, his many comings, his eschatological pledge."258 The liturgical antiphons "hallow" the process of our anticipation and preparation, as they bind the beginning and the end together. Thus, in a triumphant tone of voice, the author continues: "The period of waiting, they [the antiphons] seem to say, is nearly over. The cycle of time is almost complete: like the closing of a perfect circle. ${ }^{259}$ In a remarkable nuance to the NeoPlatonic cycle of exitus and reditus of creation back to God, his description suggests the idea that just as at genesis the world came down into being from God through His Word, so now God Himself, as the Word, comes down, in order to pull His people back up. In genesis, the creatures perform the exitus. In the Incarnation God performs it in a

\footnotetext{
${ }^{258}$ Oliver Treanor, Seven Bells to Bethlehem: The O Antiphons of Advent (Harrisburg, PA: Gracewing Publishing (1995), p.6.

${ }^{259}$ Ibid. p. 1
} 
sacrificial act to unite creatures back with Himself. God's Incarnation is itself the midpoint at which the circle bends, and his people turn back up towards Him again:

Advent is not only the celebration of God's coming to us, but also of our coming to him. It is, after all, a season of repentance. So the hour is ripe in a double sense. It is time again to mend the broken circles of our lives by returning, as a circle does, to our point of origin. Christmas makes this possible, for by the birth of God-made-man, man comes back to God in the same moment as he comes to us. Mary's Fiat made it so, when she gave all humanity to God in the very act of giving God a humanity. ${ }^{\mathbf{2 6 0}}$

The Incarnation, which bends time into a circle, is also an event of Creation. But in its return direction, it is a creation which human beings can freely choose, and in which they participate, to complete God's act of Creation and its sacred History. Ideally, without the fall, there would have been no distance between God's act of creating man and man's act of seeking God and participating in his creation. The exitus (God's act) and reditus (man participating in God's act and freely choosing to co-create the world and himself with God), would be simultaneous and immediate. The exitus of creation is not a fall as in gnostic understanding. It is unambiguous creation. The fall is in man's choice not to participate.

\section{The Five Concords}

In itself, the fact that Norton quotes from "O Sapientia," and consequent allusion of this antiphon's textual and liturgical contexts however, does not guarantee with certainty the claim that he indeed sandwiches the temporal action of the alchemical journey between a beginning and an end that are modally different, and rooted in the Incarnation. Further evidence is needed to support this claim, and show that Norton indeed shapes the journey accordingly. Book VI, which begins the first of its five

\footnotetext{
${ }^{260}$ Ibid. p. 2
} 
"concords" with this quotation, does offer such evidence. Book VI rises to a wide and inclusive perspective to pull his account of the entire journey together into these five concords. Norton not only begins his account of the five concords with God, but also ends them with God. He begins at the center, focused on the initiate himself, and his intentionality. The "O Sapientia" allusion places his intentionality at the center, and places the Incanate Christ, Word and Wisdom, at the center of this intentionality. The journey thus begins from the inner boundaries where the pilgrim seeks Christ beyond the limits of his mind. Simiarly the journey also ends with boundaries - the ourtermost boundaries of the macrocosm, identical with those of the microcosm-and with God beyond them. It ends with a bird's eye view of the entire cosmos, with God as mover and as "formall" principle, binding the primum mobile and all the circles within it into shape and orderly movement.

Norton shapes the five concords into widening circles of inclusiveness. At the center is the pilgrim's intentionality and Christ at the center of the center, as intentional referent. At the end of the journey, and outside the limits of the outermost circumference is God both as mover and as formal binder of that outermost circumference. In each of these concords he inserts reference to form and limits. He begins the chapter by informing his reader that there are "V Concordis he moste vndirstonde" (VI, 2690):

The first Concorde is nede to merke, Whethir his mynde accorde with the werke Which shall be lorde to pay for all, Ells all your lab[o]ur destroye he shall; The ijde concorde is nedfull to kenn Bitwen this crafte and hirr werkmen; The iijde shall well serve your ententis, When werke concordith with Instrumentis; The iiijth concorde most well be sowgth With ye place where it shall be wrogth; For trewly it is no litill grace 
To fynde a perfite worchynge place;

The vth is of concorde and of love

Bitwen your werkis and the spere above; (VI, 2689-2704)

The reader will better be able to apprehend the entire movement from the first to the last, by keeping in mind that all these concords are acts of concordance, and that all are part of a single and complete action which produces an ontologically complete microcosm. Regarding the concord between the alchemist's mind and his "werke," Norton has repeatedly emphasized, as discussed above, that the "werke" must be utterly inclusive of the entire range of being. Otherwise it would fail. Its inclusiveness depends on the alchemist's intentional referent. If that referent is a partial good in the spatio-temporal world, he will be not better than the rest of the alchemical hopefuls Norton lists in his "Prohemium," whose work, as discussed above, is caught in a state of endless deferral. The referent of his intentionality must be the ultimate and complete Good. It must be divine, and beyond the spatio-temporal world. On the surface, Norton's warning that the "werke" "shall be lorde to pay for all, / Ells all your lab[o]ur destroye he shall" (2693-94) states that unless your work is successful, and is able to pay all its expenses, you will lose all and end up poor. But it also contains an allusion to Christ who is "lord" and who "pay[ed] for all," thus identifying the "werke" with Christ. For the alchemist to be able to complete his redemptive journey successfully, he must begin with Christ as the starting point of his work and referent of his intentionality.

Norton's list of the five concords is not merely encyclopedic or paratactic. Through its movement from the first to the last concord, Norton's text is also enacting a journey through widening circles until the outer boundaries of the universe. The journey is not merely spatial. While the first concord defines the "werke" as an act of intentionality, the second concord, between the craft and the laborers, defines it as a 
"craft" which is realized through physical labor, performed temporally and understood sensibly. As part of the action as a whole, its partial and sensibly defined goals are teleologically oriented towards the alchemist's final goal and intentional referent. The third concord between the "werke" and the "Instrumentis" defines the action, on the rational level. The alchemist uses his tools to control the degrees and proportions of the work: "Bi manyfolde stoppellis degrees ye may gete" (VI.2892). Presumably, he is able to do so through the "many meenes" (V. 2408) in nature. The tools are, in a sense, extensions of the rational part of the alchemist's being, as the laborers were extensions of his physical and sensible work. Here the alchemist relates to his goal as a rationally defined purpose, his "ententis," which the tools serve. The fourth, the concorde of the work "With ye place where it shall be wrogth," Norton conceives of on the basis of the balance of the four elements in that place, and the resultant qualities, as for example "Some placis most nede be euermore drie, / . . Som most be derke or dym of lyght, / . . Som placis most nedly be moyst \& colde" (VI, 2905; 2907; 2911). The fifth and final concorde is a relationship of love with "the sphere above." In this way one can claim that the journey through the five concords begins in God and ends in God. However, Norton's ending in God remains only implied and not directly stated. In his description of this concord he speaks of the influence of the stars. The alchemist must time his work in accordance with astrological influences, since "in werkis of generacion," the elements of the stone "Haue most obedience to constellacion" (VI, 2940-42). Nevertheless, "love" is essentially a personal act. A relationship of "love" with the "sphere above" naturally invokes God, who is pure Love and its source in the cosmos.

Once the journey through the widening circles has been completed, it undergoes a reversal. Norton lifts up his reader's mind to a bird's eye view of the entire cosmos, 
describing it in a few lines, which begin from the outermost boundary of the cosmos, the Primum Mobile, and descend through the narrowing circles back to the center, to the same location where the journey had begun: the alchemist's intentionality. But whereas Christ was at the center, at the beginning, the product of the journey, the Stone, or “Elixir" has been deposited. There is a remarkable contrast between Norton's version of this reversal and that in tis greatest representation and enactment, namely in Dante's Divine Comedy. There, Dante perceives his journey through the Paradiso as a movement outward into more inclusive widening circles. Once he reaches the Primum Mobile, however, with God beyond it, and the reversal occurs, it is unambiguously God whom Dante discovers to have been at the center all along. At the center of Norton's reversal, however, is the artefact that has been collaboratively produced by man, nature and, presumably God. Norton begins the return journey with the outer boundary of the cosmos, where the natural world meets the divine, and where St. Augustine locates his celestial "scroll." But Norton seems to be as careful to keep the narrative of his operation on the inside of that boundary as much as he is also careful to definitely reach that boundary and assert its presence. He begins his return journey with "ye mover of ye orbe" (2959), which alludes to the First Mover, but also applies to the Primum Mobile itself. He is binding up the universe by means of divine power, and God as Formal Cause, but insisting on remaining within the universe, and receiving the divine influence from within it as well:

The virtew of ye mover of ye orbe ys formall, The virtew of ye viijth spere is here Instrumentall, With his signis \& figuris \& parties aspectuall;

The planet virtue is propre \& speciall; The virtew of Elementis is here Materiall, The virtew infuside resultith of them all. The firste is like to a werkman his mynde, The ijde. like to his hande ye shall fynde; 
The iijde. is like to a good Instrumente;

The remenant like a thyng wrogth to your entent. Make all ye premyssis with other well accorde, Then shall your meritis make yow a grete lorde. These wysis Elixer of whom we make mencyon Ys gendrid, a thyng of a secunde intencion. (VI, 2969-2972)

Norton's phrase "ye mover of ye orbe," however, can hardly avoid invoking God as Prime Mover. Norton's description of the "virtew" of what presumably is the Primum Mobile, as being "formall" can hardly fail to invoke God as the "Formal Cause" of creation, and thus to Christ as the "Word" through Whom creatures receive their form and distinction. However, God's presence beyond the boundaries is there by implication instead of outright statement. One does not use "virtew" for the power of God, but for the effects of His presence, with which He has infused the heavenly spheres. Thus although "ye mover of ye orbe" with its "virtew" "formall" invokes God, it is, in its direct sense, the Primum Mobile which causes the spheres within it to turn in the opposite direction from itself. Norton's description then takes the reader quickly, through the miniature microcosmic space of the fourteen lines 2969-2972, downward and inward. Moving down from the Primum Mobile Norton first passes the zodiacal sphere, "ye viijth spere" which renders the firmament a script: "With his signis \& figuris \& parties aspectual." Enclosed within this eighth sphere are the narrower spheres of the seven planets followed by the four elements, and, finally, all zeroes in onto the Stone that "Ys gendrid."

The descending sequence from the wider to the narrower circles is not the only aspect of the reversal that Norton effects in lines 2959-2972. Another reversal of crucial importance has clandestinely taken place. At the beginning of the first concord and of the entire journey from the center outwards, stood the alchemist's mind, at the center and turned towards the Word. The physical, sensible, rational, elemental and zodiacal spheres 
were outside his mind, larger and "out there." In the return journey, however, the alchemist's mind has become one with the outermost sphere, which is "like," i.e., in concord with, "the workman his mynde." The movement reversed movement, now turned inwrds, has become a movement through the alchemist's, or contemplative pilgrim's mind. The next sphere moving inwards and downwards, the eighth, is identified with the second concord, and the next after that, the sphere of the planets, with the third concord. What at first was the narrowest concord, the alchemist's mind, is now the widest and most inclusive, and the rest of the universe is all contained within it. The "remenant," by which Norton may mean the spheres of the four elements below the Moon, are "like,"i.e., in "concord" with—“a thing wrogth to your entent" (2968). This "thing" that is "wrogth" is the alchemical opus, the philosopher's stone, the alchemist's mind, as well as author's and reader's, and, finally, the Ordinal itself. Norton wants to elaborate a little and emphasize the end of the journey in a Stone that includes all the ontological layers of the journey. He recapitulates what he has taught his reader: he now collects the concords together and speaks of them not in relation to the "werke," since they now are that work, but in relation to each other, as part of a whole: "Make all ye premyssis with other well accord," and you shall have merited lordship. "These wysis," i.e., in these ways, or, by means of these ways, namely the concords, the "Elixer of whom we make mencyon [in line 2968] / Ys gendrid," and it is "a thing of a secunde intencion" (2971-72). The entire movement down through the microcosmic spheres, collects together, like widespread motion, into a single drop: the "secunde intencion." In ending his journey with that new and surprising 'name' for the Philosopher's Stone, Norton achieves another feat of allusive power, at the end of the five-concords, similar to the power of the advent antiphon allusion at the beginning of these 5 concords. "Secunde intencion" was an 
important term in medieval phenomenology, and has fundamental implications for the concept of art and artistic production.

By referring to it in its capacity as "Elixer," Norton brings in the healing power of the Stone. He also calls it "a thing of a secunde intencion." In a paper read in an "Interdisciplinary Seminar on the concept of 'complexity'," Fulvio Di Blasi explains that for Thomas Aquinas there are three kinds of "objects of human knowledge." The object of the "first intention" is the "material thing itself, the 'res' (quidditas rei materialis...)." But actually it can also be understood as the object that is beyond the mind-not merely the material object, but the ultimate object that the mind seeks beyond itself, namely God. The object of the second intention, in Di Blasi's explanation, is "the intelligible species abstracted from the phantasm." In other words, it occurs when the intellect steps back from the "res" 'out there', to consider the essence or nature it has perceived. It becomes self-conscious, and examines itself, as Ripley and Norton also examine the means by which the mind comes to know. The third, he gives as "the ens in universali (common object)." The ens is 'being' and 'essence,' and is inclusive of both the first and second intentional referent. $^{261}$ The implication of Di Blasi's tripartite description is that Ens which is the object of knowledge from at an advanced stage of self-reflection and awareness, is not merely the essence or species of a single thing, but being itself as a whole, which is the essence of all things. Such a stage of perception would be similar to the last stage of Bonaventure's Journey, when the intellect becomes gathered together into a microcosm and ready to take the leap across its mortal limits, into union with God.

\footnotetext{
261 Fulvio Di Blasi, “The Concept of Truth and the Object of Human Knowledge," Readings, Thomas International Project (McInerny Center for Thomistic Studies, nd.), http://www.thomasinternational.org/ralphmc/readings/diblasi001.htm, 11 April, 2014. Paper read at the Interdisciplinary Seminar on the concept of 'complexity', in explanation of an article he had published "an article I published on the philosophical knowledge of God in Thomas Aquinas."
} 
When, finally "ens" is the object, or referent, of the intellect's intention, this intellect would then have climbed the ladder through species and genera till their end. Ens would be the ultimate species, or the species of all species, Christ himself, as both the object of knowledge and the means to it, as described by Bonaventure and as Michel Karnes argues Bonaventure understood the role of Christ in the mind's journey to wisdom. ${ }^{262}$

In Medieval Commentaries on Aristotle's Categories, Georgio Pini states that "Largely as a result of the influence of Al-Farabi and Avicenna, logic came to be considered as the study of a particular class of concepts, the so-called second intentions." 263 The concept of "second intention" was a matter of debate during the Late Middle Ages and early Renaissance. According to Pini, Duns Scotus treats the object of knowledge of the second intention as an abstract concept. For Scotus the concept that is the referent of the mind in its second intention is known "by means of a comparison among concepts." ${ }^{264}$ Such an understanding of "second intention" would carry us far from the context in which Norton is using it-the context of a microcosm and philosopher's stone which unites all the ontological and epistemological layers of one's - and the universe's - being and intellect. Modern scholars also debate the way Aquinas conceived of "second intentions." Rather than being derailed by entering such debates, we can go directly to Aquinas' own statements, which fit the context of Norton's Philosopher's Stone as "second intention" and can help explain what Norton means by that expression.

The introductory chapter above has pointed out Aquinas' idea that the mind aquires the form of the its intentional referent, which is the 'object' it seeks or

\footnotetext{
${ }^{262}$ See Chapter Three above.

${ }^{263}$ Georgio Pini, "Reading the Categories as an Introduction to Logic," Medieval Commentaries on Aristotle's Categories, ed. Lloyd A. Newton (Leiden: Brill, 2008), 154.

${ }^{264}$ Georgio Pini, "Scotus' Logic and His Metaphysics? Reply to Bates," Medieval Commentaries on Aristotle's Categories, ed. Lloyd A. Newton (Leiden: Brill, 2008), 285.
} 
contemplates: "The thing understood is in the intellect by its own likeness; and it is in this sense that we say that the thing actually understood is the intellect in act, because the likeness of the thing understood is the form of the intellect" (ST, I q.85.a.2, repl obj.1). ${ }^{265}$ Aquinas identifies species with the act of knowing it. The intellect acquires the "form" of its referent not merely in terms of a static image, but in dynamic and living terms: the intellect acquires in operation, the form of that which it seeks. That form "is the intellect in act." The operation of knowledge may be in some senses instantaneous. But it also unfolds in time, as Norton's journey through the five concords unfolds in both time and space, turning both into an architectural whole. But the mind can turn time and spacethe "meen space" into that architectural whole only if the object of its knowledge- the ultimate referent which inspires its movement-is a "whole." When the intellect climbs up the ladder of species and genera until it reaches the primum mobile, and relates to God beyond those limits, then the object of its knowledge is divine and whole, and then also the intellect's unfolding in time can become shaped into an architectual whole. But in addition to becoming shaped into a cosmos, the mind needs to know that it has become shaped into a cosmos, and to understand the principle by virtue of which it has been able to do so:

Therefore it must be said that the intelligible species is related to the intellect as that by which it understands.... But since the intellect reflects upon itself, by such reflection it understands both its own act of intelligence, and the species by which it understands. (ST, I q.85.a.2, repl obj.1)

By naming the Stone "a thing of a secunde intencion," Norton is calling attention to its self-reflexive nature. But whose "intencion" is it? The logic of the language indicates that Norton is referring to it as someone's intention, and not merely to is as its own self-

${ }^{265}$ See page 26 above. 
reflexive intention. In other words, the Stone is the alchemist's, the poet's and the reader's "secunde intencion." The poet has objectified his mind, and can now look ar it, examine it, "separate" and "conjoin" it, and offer it for interpretation. A second intention is a work of art that offers itself both as an operation of knowledge to be enacted, and, at the same time, as a means by which the poet's or reader's mind can examine this operation and come to know it in its details and its totality, like that "Ornament" in the tailpiece of British Lib. MS Add. 5025-4 of the Ripley Scroll.

The second intention can be understood as an analogy to Christ as God's own self knowledge. In a sense, Christ is the Father's second intention: God looking at Himself and knowing Himself. By analogy, the Stone is man's second intention: it is man's selfreflexive knowledge of his own mind...but with a difference. God is the ultimate truth and knows Himself as such. But man is not the ultimate referent of his own intentionality. Neither is his mind substantial except by having God as his ultimate referent. God looks need look no further than His self-knowledge. When man looks at anything, he is ultimately looking beyond himself and seeking God. The "thing of a secunde intencion," is a paradoxical hermeneutical project that is self-enclosed, and yet that is self-enclosed only by virtue of its seeking beyond itself.

My argument has tended towards the idea that Norton does not allow a complete conflation of the Stone with Christ. As a thing of man's second intention, his selfknowledge--it is like Christ, but it is not Christ himself, God's self-knowledge. It does not take his place. It is an artifact which now encapsulates into dynamic embodiment, within miniature form, all the physical, intellectual and cosmic operations through which it has been "gendrid." It is a miniature, embodying not only the entire cosmos, but the 
operation that produces it. However, this operation is not man's act alone, but God's as well.

Norton ends his sixth chapter and the five-concord journey by exhorting the reader to reject the occult: This meaning is supported by Norton's exhortation against occult practices and beliefs in the lines that immediately follow:

These wysis Elixer of whom we make mencyon

Ys gendrid, a thyng of a secunde intencion.

Trust not Geomancye, that supersticious arte,

For god made reason which yer is sett aparte;

Trust not to all astrologyeris, I say why,

For that arte is as secrete as alchymye.

That other is disprovide, and playnly forbodde

By holy sayntis of the church of gode.

Trust not, ne love not Nigromancye,

For it is appropriede to the devill to lye;

Norton is here exhorting his readers against the occult form of alchemy. The indications are that his Ordinal was an effort to lift alchemy up from its ancient duality, and base it on positive grounds. 


\section{Appendix}

Fig. 1: Signaculum mundi pythagoricum by Helisaeus Roeszlin (also Roeslin) (15451616), ${ }^{\mathbf{2 6 6}}$ available in William Cooper's $A$ Philosophical Epitaph of W. C. Esquire (London: Pellican, 1673). This illustration is also sometimes referred to as "Mundus Archetypus." A. E. Waite includes it with Norton's Ordinal in his Hermetic Museum Vol II, 9.

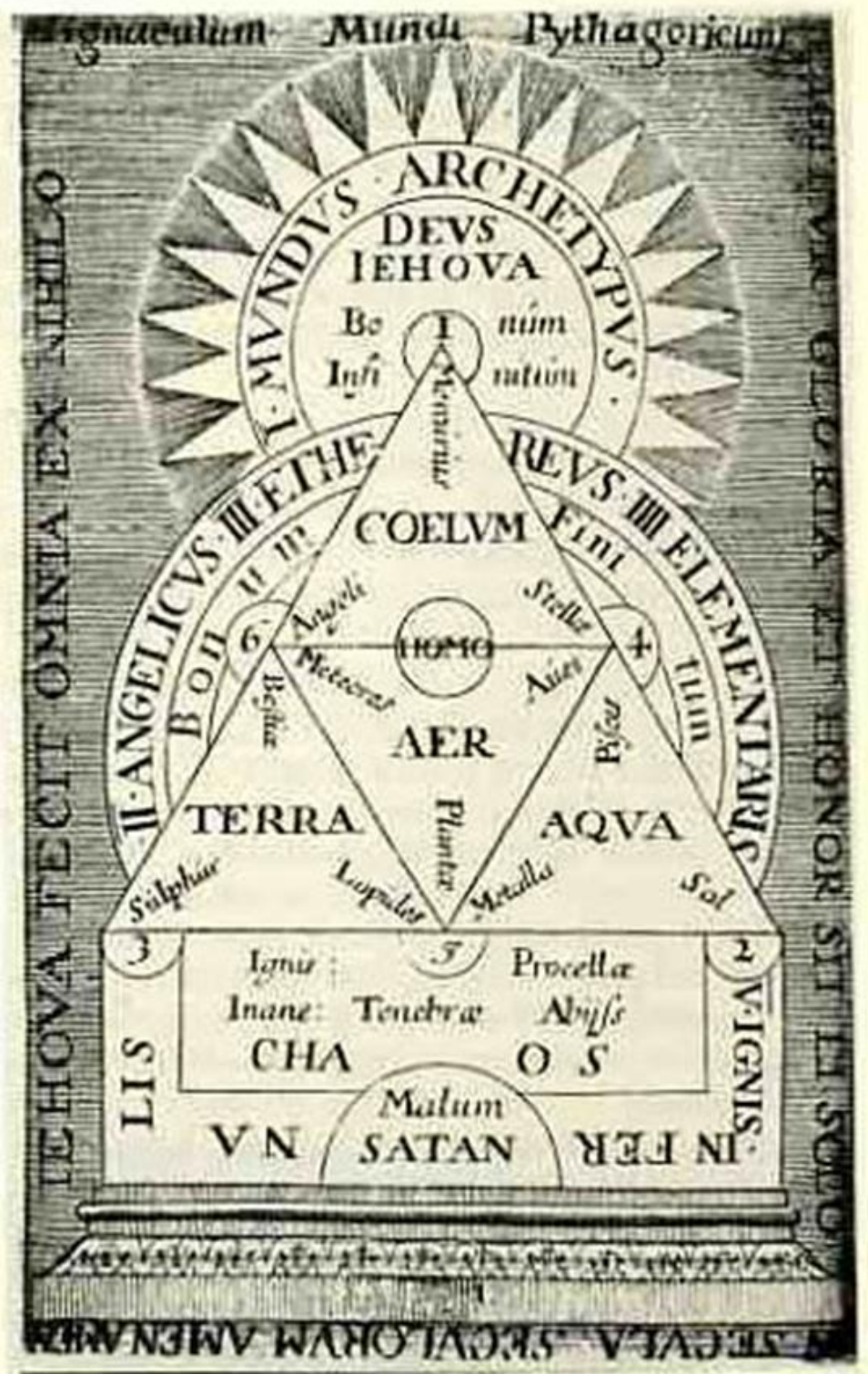

266 Francois Secret and Antoine Faivre, "Histoire de l'ésotérisme chrétien," École pratique des hautes études, 5e section, Sciences religieuses 79.1970 (1971-1972): 363374, 364. Secret and Faivre mention that Signaculum mundi pythagoricum by Helisaeus Roeszlin was reproduced by the editor of Michael Maier's (1568-1622) Tripus Aureus. Cf. Susanna Akerman, Rose Cross Over the Baltic: The Spread of Rosicrucianism in Northern Europe (Leiden: Brill, 1998), 207 also attributes the Signaculum mundi pythagoricum to Helisaeus Roeszlin (Roeslin). Nigel Pennick, Sacred Architecture of London (London: Aeon Books, 2012), states that this diagram originated with Norton: "One important [sacred] diagram, originating with the late fifteenth century Bristol alchemist, Thomas Norton, was significant enough to appear in several versions. This is the Signaculum Mundi Pythagoricum, a diagram associated with his Ordinall of Alchemy (1477) published in Britain in 1653. This diagram appears In Norton's Tractatus chymicus, (Frankfurt, 1616); Elias Ashmole's Theatrum chymicum Britannicum (London, 1652) and W. Cooper's The Philosophical Epitaph, (London, 1673). The Bristol legendarium tells how Norton made the red elixir, which then being stolen, was used to build the church of St Mary Redcliffe in that city" (46-58). Waite included this illustration with Norton's Ordinal in his Hermetic Museum, Vol. II, 9. 


\section{Works Cited}

Abt, Theodore, ed. The Book of Pictures [Mushaf As-Suwar] by Zosimos of Panoplis, Corpus Alchemicau Arabicum vol. II.2, trans. Theodore Abt and Salwa Fuad. Zurich: Living Human Heritage Publications, 2011.

Akerman, Susanna. Rose Cross Over the Baltic: The Spread of Rosicrucianism in Northern Europe. Leiden: Brill, 1998.

Al-Hassan, A. Y. "The Arabic Origin of Jabir's Latin Works: A New Light on the Geber Question." Journal for the History of Arabic Science, Vol. 10, Numbers 1 \& 2, Aleppo: Institute for the History of Arabic Science (1994): 5-11.

. et al, eds. The Different Aspects of Islamic Culture - Science and Technology in Islam, vol. IV, Part II, UNESCO (2002). http://www.history-science-technology.com/articles/articles\%204.htm\#*. Accessed Jan. 29 2013.

Ashmole, Elias, 1617-1692, ed., Theatrum Chemicum Britannicum: containing severall poeticall pieces of our famous English philosophers, who have written the hermetique mysteries in their owne ancient language. London: Printed by J. Grismond for Nath: Brooke, at the angel in Cornhill (1652).

Aspell, Patrick J. Medieval Western Philosophy: The European Emergence, Cultural Heritage and Contemporary Change, Series I, Culture and Values vol. 9 (The council for Research in Values and Philosophy, 1999).

Bakalis, Nikolaos. Handbook of Greek Philosophy: From Thales to the Stoics Analysis and Fragments. Victoria, BC: Trafford Publishing, 2005.

Bakewell, Charles M. Source Book in Ancient Philosophy. New York: C. Scribner's Sons, 1907.

Beal, Peter. A Dictionary of English Manuscript Terminology 1450-2000. Oxford: Oxford University Press, Online Version: 2012. Print Publication Date: 2008.

Benson, L. D., ed. The Riverside Chaucer, 3rd ed. Boston: Houghton Mifflin, 1987.

Berlekamp, Persis. "Painting as Persuasion: A Visual Defense of Alchemy in an Islamic Manuscript of the Mongol Period.” Muqarnas, vol. 20 (2003): 35-59. 
Berthelot, Marcellin, ed. and trans. Collection des anciens alchimistes grecs. Paris: G. Steinheil, 1887-88. 3 vols.

. "Isis to Horus," in Collection des anciens alchimistes grecs, 3 vols. vol. I. Paris: G. Steinheil, 1887-1888, xiii, 1f.

Boas, George, trans. Journey of the Mind into God-St Bonaventure, Crossroads Initiative, Web, accessed April 8, 2014. Rp. of Boas, George ed. and tr., The Mind's Road to God. Upper Saddle River, NJ: Prentice Hall, 1953.

Bovie, Smith Palmer. Satires and epistles of Horace: a modern English verse translation. Chicago: University of Chicago Press, 2002.

Bridges, Vincent, and Burns, Teresa. "Olympic Spirits, the Cult of the Dark Goddess, \& the Seal of Ameth." The Consecrated Little Book of Black Venus attributed to John Dee. Eds. T. Burns and N. Turner. Cold Springs, N.Y.: Waning Moon Publications, Ltd., 2007.

"The Little Book of Black Venus -Part Two: Olympic Spirits, the Cult of the Dark Goddess, and the Seal of Ameth." Journal of the Western Mystery Tradition vol. 2, no. 13 (2007).

Britt, Matthew O.S.B., Rev., ed. The Hymns of the Breviary and Missal. Pref. by Rt. Rev. Msgr. Hugh T. Henry. London: Burnes Oates \& Washbourne Ltd. 1922.

Brown, Benjamin "Bonaventure on the Impossibility of a Beginningless World: Why the Traversal Argument Works" American Catholic Philosophical Quarterly vol. 79, Issue 3 (Summer 2005): 389-409.

Burgert, Edward, in The Dependence of Part I of Cynewulf's Christ Upon the Antiphonary. J.D. Milans \& Sons, 1921.

Burnett, Charles. "The Coherence of the Arabic-Latin Translation Program in Toledo in the Twelfth Century." Science in Context, 14 (2001): 249-288.

Burns, Teresa, “Concerning Ed. Kelley's Poem," Journal of the Western Mystery Tradition vol. 2 no. 15 (Autumnal Equinox 2008).

Butcher, S. H. ed. and trans. The Poetics of Aristotle. New York: MacMillan and Co., Ltd. 1902.

Bynum, Caroline Walker. Fragmentation and Redemption: Essays on Gender and the Human Body in Medieval Religion. NY: Zone Books, 1991.

Jesus as Mother: Studies in the Spirituality of the High Middle Ages. Berkley: University of California press, 1982.

. The Resurrection of the Body in Western Christianity,200-1336. New York: Columbia University Press, 1995. 
Cervone, Cristina Maria. Poetics of the Incarnation: Middle English writing and the leap of love. Philadelphia: University of Pennsylvania Press, 2012.

Chance, Jane. Review. Paul Beekman Taylor, Chaucer's Chain of Love. Madison and Teaneck, N.J.: Fairleigh Dickinson University Press; London: Associated University Presses, 1996. International Journal of the Classical Tradition (Summer 1999).

Chrisciani, Chiara Opus and sermo: The Relationship between Alchemy and Prophecy (12th-14th Centuries), Early Science and Medicine 13 (2008) 4-24.

Cooper, William. A Philosophical Epitaph of W. C. Esquire. London: Pellican, 1673.

Copeland, Rita and Melville, Stephen, "Allegory and Allegoresis: Rhetoric and Hermeneutics," Exemplaria, 3 (1991), pp. 159-87.

Cullen, Christopher M., Bonaventure. Oxford: Oxford University Press, 2006.

Dales, Richard C., Medieval Discussions of the Eternity of the World. Leiden: Brill Archive, 1990.

Deane, William J. Sopphia Salōmon. The book of Wisdom; the Greek text, the Latin Vulgate, and the Authorised English version. Oxford: The Clarendon press, 1881.

Fulvio Di Blasi, "The Concept of Truth and the Object of Human Knowledge," Readings, Thomas International Project (McInerny Center for Thomistic Studies, nd.), http://www.thomasinternational.org/ralphmc/readings/diblasi001.htm, 11 April, 2014. Paper read at the "Interdisciplinary Seminar on the concept of "complexity."”

Douay-Rheims. The Holy Bible translated from the Latin Vulgate: diligently compared with the Hebrew, Greek, and other editions in divers languages: the Old Testament first published by the English College at Douay, A. D. 1609, and the New Testament first published by the English College at Rheims, A. D. 1582, published with the approbation of James Cardinal Gibbons. Baltimore: John Murphy Company, 1914.

Duhem, Pierre Medieval Cosmology: Theories of Infinity, Place, Time, Void, and the Plurality of Worlds, tr. Ariew, Roger. University of Chicago Press, Aug 15, 1987.

Egmont Lee, Sixtus IV and Men of Letters. Rome: Ed. di Storia e Letteratura, 1978.

Fathers of the English Dominican Province, eds. and tr. Summa Theologica: First Complete American Edition in three Volumes, vol. I, tr. New York: 
Benziger Bros., Inc., 1947. CCEL, http://www.ccel.org/ccel/aquinas/summa.html.

Flood, Gavin D., ed., Invisible Worlds (Edinburgh: Edinburgh University Press, 1993).

Franz, Marie-Louise von, Alchemy: An Introduction to the Symbolism and the Psychology. Toronto: Inner City Books, 1980), based on a series of lectures given in 1959 at the C.G. Jung institute in Zurich.

Freccero, John. Dante: The Poetics of Conversion, ed. Rachel Jacoff. Harvard University Press, 1986.

. "On Dante's Medua” in Marjorie Garber and Nancy J. Vickers, eds., The Medusa Reader. New York: Routledge, 2003, 111-121.

Ferguson, John, ed. Biblioteca Chemica, 1908.

Gellrich, Jesse M. The Idea of the Book in the Middle Ages: Language Theory, Mythology, and Fiction. Ithaca: Cornell University Press, 1985.

Grant, Edward. A Source Book in Medieval Science. Cambridge: Harvard Univ. Press, 1974.

Greenwood, Leonard Hugh Graham, ed. and tras. .Aristotle Nicomachean ethics: Book six, with essays, notes, and translation. Cambridge: Cambridge, University press, 1909.

Gummere, Richard Mott, tr., Seneca, Ad Lucilium epistulae morales: with an English translation, (3 vols), vol. 1. Eds. Capps, E., Page, T. E. and Rouse, W. H. London: William Heinemann Ltd., 1918, rpt. 1925.

Henry, Hugh Thomas. “O Antiphons,” Catholic Encyclopedia 11 (1913).

Holsinger, Bruce W. Music, Body, and Desire in Medieval Culture: Hildegard of Bingen to Chaucer. Stanford: Stanford University Press, 2001.

Horace. Horace's Complete Works. London: Dent, New York, Dutton, 1911, rpt 1953.

Hughes, Jonathan. "Politics and the Occult at the Court of Edward IV," Princes and princely culture, 1450-1650, Volume 2. Eds. Martin Gosman, Alasdair A. MacDonald, Arie Johan Vanderjagt. Leiden: Brill, 2005.

Ibn Umail. The Great Vision of Muhamm ad Ibn Umail. Los Angeles: C.G. Jung Institute of Los Angeles, 2003.

Joachim, H. H., trams. On Generation and Corruption, (Oxford, The Clarendon Press, 1922). 
Jones, Julian Ward, and Jones, Elizabeth Frances eds. The Commentary on the First Six Books of the Aeneid of Vergil Commonly Attributed to Bernardus Silvestris. Lincoln: University of Nebraska Press, 1977.

Kahn, Didier, "Alchemical Poetry in Medieval and Early Modern Europe: A Preliminary Survey and Synthesis Part I - Preliminary Survey," Ambix 57, no. 3 (November 2010): 249-74.

Karnes, Michelle. Imagination, Meditation, and Cognition in the Middle Ages (Chicago: University of Chicago Press, 2011).

Klein, A., ed. and tr., Die Monas-Hieroglyphe von John Dee aus London (Interlaken, Switzerland: Ansata-Verlag, 1982), 124-126, 130-132, online at http://www.jwmt.org/v2n15/garland.html.

Kurt Ruh. Bonaventura Deutsch: Ein Beitrag zur deutschen Franziskaner-Mystik und Scholastik. Bern: Franke Verlag, 1956.

Kuzmic, Tomislav ed. Eudict: European Dictionary (EUdict.com, 2013). Web, Accessed Nov. 30th, 2013.

Lewis, Neil. "Robert Grosseteste." The Stanford Encyclopedia of Philosophy (Summer 2013 Edition).

http://plato.stanford.edu/archives/sum2013/entries/grosseteste/.

Linden, Stanton J. "Expounding George Ripley: A Huntington Alchemical Manuscript," Huntington Library Quarterly Vol. 61, No. 3/4 (1998): 411-428, p. 414. , ed. George Ripley's Compound of Alchymy (1591). Vermont: Ashgate Publishing Co. 2001.

Luibhéid, Colm, trans., and Rorem, Paul, ed. and trans. Pseudo-Dionysius: The Complete Works, eds. (Mahwah, New Jersey: Paulist Press, 1987), Ch. I.1. 998A1000A, p. 135.

Mackay, Charles (1814-1889). Memoirs of Extraordinary Popular Delusions, Vol. 3 (of 3), (London: R. Bentley 1841), rpt. (Barnes and Noble Publishing, Inc., 2004.

Marquess of Bute. John. The Roman Breviary: reformed by order of the Holy cumenical Council of Trent; published by order of Pope St. Pius V; and revised by Clement VIII., Urban VIII., and Leo XIII; together with the offices since granted and the martyrology, Edinburgh: W. Blackwood (1908).

Marshall, John ed. Horace's Complete Works. London: Dent, New York, Dutton, 1911, rpt 1953. 
Mayhew, Robert, trans. Problems, Volume I, Books 1-19. Harvard University Press, 2011.

McCallum, R.I. "The Ripley Scroll of the Royal College of Physicians of Edinburgh," Vesalius, II, 1(1996). http://www.bium.univparis5.fr/ishm/vesalius/VESx1996x02x01x039x049.pdf. Accessed on Aug.16, 2011.

McInerny, Ralph. "Saint Bonaventure.” A History of Western Philosophy Vol. II (The University of Notre Dame Press, 1963)

."The Thirteenth Century: translations." A History of Western Philosophy, Vol. 2: From Augustine to Ockham. Notre Dame University Press, 1963. http://www3.nd.edu/Departments/Maritain/etext/hwp215.htm. accessed 20 Feb. 2014.

McLean, Adam. Adam McLean's Study Course on the Ripley Scroll. Glasgow: Adam McLean, 2002.

, ed. "The Waterstone of the Wise." The Alchemy Website.

http://www.alchemywebsite.com/sophic1.html. Accessed April 8, 2014.

Michael Maier, ed. and trans. Tripus aureus. Frankfurt (Luca Jennis), 1618.

Migne, J. P. Patrologia Graeca vol. III. Paris: Garnier Fratres Editores, et J.P. Migne Successores, 1889.

. “Compiegne Antiphoner." St. Gregory's complete works: Sancti Gregorii

Papae I: Opera Omnia. Patrologia Latina vols. IV, 733-878, and PL 78 (Paris, 1705), cols. 725-850.

- Sancti Gregorii Magni Romani Pontificis Liber Responsalis Sive Antiphonarius. In Nomine Domini Jesu Christi. Incipiunt Responsoria, Sive Antiphonae per Anni Circulum. Patrologia Latina Vol. 78. The Patrologia Latina Database, 1996-2014.

Minnis, A. J. Chaucer's Boece and the Medieval Tradition of Boethius, Chaucer Studies 18. Rochester, NY: Boydell \& Brewer Ltd, 1993.

Miranda, Salvador, ed. "Catalogues: Cardinals head of dicastries of the Roman Curiaa: Offices, Reverend Apostolic Chamber,"

The Cardinals of the Holy Roman Church: A digital resource created and produced by Salvador Miranda, consisting of the biographical entries of the cardinals from 492 to 2013 and of the events and documents concerning the origin of the Roman cardinalate and its historical evolution. Florida International University Libraries, 1998-2013. Web, http://www2.fiu.edu/ mirandas/curia.htm\#Chamber, last updated: 5 Nov, 2013, accessed 10 Nov., 2013. 
Molland, George. "Roger Bacon and the Hermetic Tradition in Medieval Science," Vivarium 31 (1993).

Newman, William R. Promethean Ambitions: Alchemy and the Quest to Perfect Nature. London: University of Chicago Press Ltd., 2005.

. "Technology and Alchemical Debate in the Late Middle Ages." Isis 80.3 (Sep. 1989): 423-445.

Nicholson, Helen J. The Knights Hospitaller. Woodbridge: Boydell \& Brewer, 2001.

Nickelsburg, George W. E. and James C. Vander Kam, eds., 1 Enoch: a new translation : based on the Hermeneia commentary. Minneapolis: Fortress Press, 2004.

Obrist, Barbara, "Views on History in Medieval Alchemical Writings," Ambix 56, no. 3 (November, 2009): 226-338.

Pegis, Anton C., ed., Introduction to Saint Thomas Aquinas (New York: The Modern Library, 1948.

Pennick, Nigel. Sacred Architecture of London. London: Aeon Books, 2012.

Petrarch, Francis. "Tale of Griselda," from Robert D. French, A Chaucer Handbook. New York, 1927. The Geoffrey Chaucer Page, prepared and maintained by Larry D. Benson (C) The President and Fellows of Harvard College, Last modified: May, 5, 2006.

Pini, Georgio. "Reading the Categories as an Introduction to Logic." Medieval Commentaries on Aristotle's Categories. Ed. Lloyd A. Newton. Leiden: Brill, 2008.

. "Scotus' Logic and His Metaphysics? Reply to Bates." Medieval Commentaries on Aristotle's Categories. ed. Lloyd A. Newton. Leiden: Brill, 2008.

Plessner, M. "The Place of the Turba Philosophorum in the Development of Alchemy," Isis, Vol. 45, No. 4 (Dec., 1954): 331-338.

Principe, Lawrence M. The Secrets of Alchemy. Chicago: The University of Chicago Press, 2013.

Rampling, Jennifer M. "John Dee and the alchemists: Practising [sic] and promoting English alchemy," Studies in History and Philosophy of Science in the Holy Roman Empire, 43 (2012) 498-508. 
Rampling, Jennifer M. "The Catalogue of the Ripley Corpus: Alchemical Writings Attributed to George Ripley (d. ca. 1490)," Ambix 57 No. 2 (July, 2010): 125-201.

Rankin, Susan. "The liturgical background of the Old English Advent lyrics: a reappraisal," Learning and Literature in Anglo-Saxon England: Studies Presented to Peter Clemoes on the Occasion of his Sixty-Fifth Birthday, eds., Michael Lapidge and Helmut Gneus. Cambridge: Cambridge University Press, 1985. pp. 317-37.

Read, J. Prelude to Chemistry: an Outline of Alchemy, its Literature and Relationships. London: G. Bell and Sons, Ltd., 1936.

Reidy, John ed. Thomas Norton's Ordinal of Alchemy. Oxford: Oxford University Press for the Early English Text Society, 1975.

Ripley, George. "Treatise of Mercury and the Philosophers' Stone,” McLean, Adam, ed., Aurifontina Chymica: or, a collection of fourteen small treatises concerning the first matter of philosophers, for the discovery of their (hitherto so much concealed) Mercury. Which many have studiously endeavoured to hide, but these to make manifest, for the benefit of Mankind in general. London, 1680. rp. The Alchemy Website, n.d.

Roberts, R. J., and Watson, A. G. John Dee's Library Catalogue. London: Bibliographical Society, 1990.

Robinson, ed. The Works of Geoffrey Chaucer. Boston: Houghton Mifflin Company, 1957.

Robinson, Paschal. "Bonaventure The Catholic Encyclopedia ",(1917) ,in Aristotle et al.: Readings for Philosophers and Catholics, eds. Charles G. Herbermann et al. Notre Dame: University of Notre Dame, Jaques Maritain Center, 2010. Web. http://maritain.nd.edu/jmc/etext/bonavent.htm, last modified 3 Dec. 2011, last accessed 11 Jan. 2013.

Russell, George and Kane. George, eds., Piers Plowman: The C Version. Will's Visions of Piers Plowman, Do-Well, Do-Better and Do-Best, in George Kane, ed., Piers Plowman: The Three Versions. London: Athlone, 1997.

Ryan, John K., ed. and tr., The Confessions of Saint Augustine. New York: Random House Inc, rpt. 2011.

Sacrae bibliae. in quo continentur quinque libri Moysi, libri Iosue, et Iudicum, liber Psalmorum, Prouerbia, Salomonis, liber Sapientie, et Nouum Testamentum Iesu Christi. London: Thomas Bertheletus (July 1535). http://eebo.chadwyck.com. 
Saintsbury, George, “The English Chaucerians: Lydgate.” Ward \& Trent, et al., eds. The Cambridge history of English and American literature: An encyclopedia in eighteen volumes, Vol. II, The End of the Middle Ages. New York: G.P. Putnam's Sons; Cambridge, England: University Press, 1907-21. New York: Bartleby.com, 2000. www.bartleby.com/cambridge/.

Salmon, William, ed. and trans. Hermetis Trismegisti Tractatus Aureus: The Golden Work of Hermes Trismegistus; Translated out of Hebrew into Arabick, then into Greek, afterwards into Latin; and now done out of Latin into English, Claused, and largely Commented upon, by William Salmon. Salmon, William, ed. and trans. Medicina practica, or, Practical physick shewing the method of curing the most usual diseases happening to humane bodies ... : to which is added, the philosophick works of Hermes Trismegistus, Kalid Persicus, Geber Arabs, Artesius Longavus, Nicholas Flammel, Roger Bachon and George Ripley : all translated out of the best Latin editions into English ... : together with a singular comment upon the first book of Hermes, the most ancient of philosophers : the whole compleated in three books / by William Salmon ... London: Printed for T. Howkins, J. Taylor and J. Harris, 1692.

Secret, Francois and Faivre, Antoine. "Histoire de l'ésotérisme chrétien," École pratique des hautes études, 5e section, Sciences religieuses 79.1970 (1971-1972): 363-374.

Schlosser, Marianne. "Bonaventure: Life and Works," A Companion to Bonaventure. Eds. Hammond, Jay M., Hellmann, Wayne and Goff, Jared. Leiden: Brill, 2013, 9-61.

Sedley, David. "Two Conceptions of Vacuum," Phronesis, Vol. 27, No. 2 (1982).

Sinclair, J ohn D., ed. and trans. The Divine Comedy of Dante Alighieri: 1 Inferno. New York: Oxford University Press, 1979.

Spearing, A. C. "Language and its limits : The cloud of unknowing and Pearl" in Approaching medieval English anchoritic and mystical texts, eds. Dee Dyas, Valerie Edden and Roger Ellis Rochester NY: D.S. Brewer, 2005, 75-86, 75.

Spurgeon, Caroline Frances. Five Hundred Years of Chaucer Criticism and Allusion (1357-1900): Introduction, Chaucer Society, Second Series, vol. 55 (London: Humphrey Milford, Oxford University Press, 1914-[25]).

Stavenhagen, Lee. "The Original Text of the Latin Morienus," Ambix 17 (1970). ed., and trans. A Testament of Alchemy (Hanover, New Hampshire: University Press of New England, 1974), translated and edited from the original Latin: Morieni Romani, Quondam Eremitae Hierosolymitani, de transfiguratione metallorum, et occulta, summagqu antiquorum 
Philosophorum medicina, Libellus, nusquam hactenus in lucem editus [Booklet of Morienus Romanus, of old the Hermit of Jerusalem, on the Transfiguration of the Metals and the Whole of the Ancient Philosophers' Occult Arts, Never Before Published] Being the Revelations of Morienus to Khalid Ibn Yazid Ibn Mu'Awiyya, King of the Arabs of the Divine Secrets of the Magisterium and Accomplishment of the Alchemical Art, translated from the Arabic by Robertus Castrenis,1182. Paris: Gulielmum Guillard (1559).

Szulakowska, Urszula. “The Pseudo-Lullian Origins of George Ripley's Maps and Routes as developed by Michael Maier," Mapping

. Sacrificial Body and the Day of Doom : Alchemy and Apocalyptic Discourse in the Protestant Reformation. Boston: Brill Academic Publishers, 2006.

Telle, Joachim ed. Rosarium Philosophurum Ein alchemisches Florigeluium des Spatmittelalters: Faksimile der illustrierten Erstausgabe Frankfurt 1550. Weinheim, Germany: VCH, 1992. Facsimile of the Rosarium Philosophurum. De Alchemia Opuscula complura veterum philosophorum...Part II.

Thorndike, Lynn. A History of Magic and Experimental Science, Vol. II. New York: Columbia University Press, 1923.

Thurston. “The Great Antiphons, Heralds of Christmas.” The Month. Dec., 1905.

Treano, Oliver. Seven Bells to Bethlehem: The O Antiphons of Advent. Harrisburg, PA: Gracewing Publishing, 1995.

Tredennick Hugh, tr. The Metaphysics. Aristotle in 23 Volumes, Vols.17 (Books 1-9) and 18 (Books 10-14). Cambridge, MA: Harvard University Press; London, William Heinemann Ltd. 1933, 1989.

Undusk, Rein. "Faith and Reason: Charting the Medieval Concept of the Infinite." TRAMES: A Journal of the Humanities \& Social Sciences 16, Issue 1 (2012): 3-45.

. "Infinity on the Threshold of Christianity: The Emergence of a Positive Concept out of Negativity." TRAMES: A Journal of the Humanities and Social Sciences 13, (63/58) 4, (2009): 307-340.

Valéry, Paul. Oevres. Paris: Gallimard, 1969.

Vatican. Pontifical Yearbook. Supplement. Historical notes. Città del Vaticano: Tipografia Poliglotta Vaticana, (n.d.). 
Vertot, Abbe de. The History of the Knights Hospitallers of St. John of Jerusalem; Styled Afterwards, the Knights of Rhodes, and at Present, the Knights of Malta. Translated from the French of Mons. L'Abbe de Vertot, 3 vols. vol. III. Edinburgh: Printed by R. Fleming, for A. Kincaid and A. Donaldson, Yair and Fleming; and W.Gray, Booksellers, 1770.

Villanova, Arnold of, The Rosary of the Philosphers, ed. and commentary by Adam McLean, The Alchemy Website, nd.

http://www.alchemywebsite.com/rosary0.html. Accessed 30 Mar., 2014.

Waite, Arthur E., ed., and trans. The Turba Philosophorum or Assembly of the Sages. London: George Redway, 1896.

. The Sophic Hydrolith or Water Stone of the Wise, in The Hermetic Museum Restored and Enlarged, 68-120.

. The Hermetic Museum Restored and Enlarged; Most Faithfully Instructing All Disciples of the Sopho-Spagyric Art How That Greatest and Truest Medicine of the Philospopher's Stone May be Found and Held. Now First Done into English from the Latin Original Published at Frankfort in the Year 1678 Containing Twenty-two most celebrated Chemical Tracts. Vol. II. London: James Elliott and Co., 1893.

Watefield, Robin trans., and Gregory, Andrew, intr. and notes. Plato: Timaeus and Critias. Oxford: Oxford University Press, 2008.

Weber, Robert and Gryson, Roger eds. Biblia Sacra Vulgata (Based on the Old Testament edition of the Benedictines of St. Jerome's Monastery in Rome, and the New Testament edition of Wordsworth and White, GBS, Stuttgart, 1994, 4th Ed.), quartam emendatam edition, Deutsche Bibelgesellschaft. Ed. (1983), http://www.latinvulgate.com/verse.aspx? $t=0 \& b=26 \& c=24$ or http://www.amazon.com/dp/3438053039/ref=rdr_ext_tmb.

. Biblia Sacra Iuxta Vulgata Versionem (Editio quinta) (Based on the Old Testament edition of the Benedictines of St. Jerome's Monastery in Rome, and the New Testament edition of Wordsworth and White, GBS, Stuttgart, 1994, 4th Ed.). Stuttgart: Deutsche Bibelgesellschaft, 1994.

Wickham, Edward Charles ed. Quinti Horatii Flacci opera omnia: The satires, epistles and De arte poetica ..., Vol. II. Oxford: Clarendon Press, 1891.

William R. Newman. "Technology and Alchemical debate,” Isis 80.3 (Sep. 1989): 423445 .

William R. Newman. Promethean Ambitions: Alchemy and the Quest to Perfect Nature. London: University of Chicago, Ltd., 2005. 
Wyckoff, Dorothy, trans. Albertus Magnus Book of Minerals. Oxford: Clarendon Press, 1967.

Yates, Frances A. Rosicrucian Enlightenment (Routledge Classics, 1972, rpt, Psychology Press, Nov 9, 2001.

Yonge, Charles Duke, ed. and tr. The Works of Philo Judeus. London: George Bell \& Sons, York Street, Covent Garden, 1800.

\section{Manuscripts and codices cited or mentioned}

Bodley Roll 1(The Ripley Scroll, 1500's or earlier)

Codex Marcianus 299. Marciana Library, Venice

Codex Marcianus 2325. Paris (13 ${ }^{\text {th }}$ c.)

Codex Marcianus 2327. Paris (15 th $\mathrm{c}$.)

MS Add. 5025-4 (The Ripley Scroll, 1588). British Library.

MS Cotton Vitellius EX. British Library

MS Ferguson 210, The Rosary and the Philosophers, $18^{\text {th }} \mathrm{c}$. Trans. of Rosarium Philosophorum, De Alchemia Opuscula complura veterum philosophorum... part II (Frankfurt, 1550).

MS Mellon 41 (The Ripley Scroll) England (1570). Yale Bieneke Library.

Maier, Michael. Thomas Norton's Tractatus chymicus. Frankfurt, 1616.

\section{Illustrations}

Roeszlin (also Roeslin), Helisaeus. Signaculum mundi pythagoricum (1545-1616). 